\title{
EARLy DEVELOPMENT OF THE
}

Human Pelvic Diaphragm

WiJNAND F.R.M. KoCH 
Address of correspondence:

Wijnand F.R.M. Koch

Medisch Centrum Alkmaar

Polikliniek Urologie, 031

Wilhelminalaan 12

1815 JD Alkmaar

The Netherlands

Printed by Marcelis van der Lee - ADU, Heerhugowaard

ISBN 10 - 90-9020736-8

ISBN 13 - 978-90-9020736-0

Desktop publishing by Beeldgroep MCA, Alkmaar 


\title{
Copyright
}

\author{
transferred to
}

Springer Verlag GmbH Germany

2006 


\title{
EARLY DEVELOPMENT OF THE \\ Human Pelvic Diaphragm
}

\author{
PROEFSCHRIFT \\ ter verkrijging van \\ de graad van doctor aan de Universiteit Twente, \\ op gezag van de rector magnificus, \\ prof.dr. W.H.M. Zijm, \\ volgens besluit van het College voor Promoties \\ in het openbaar te verdedigen \\ op vrijdag 30 juni 2006 om 13.15 uur
}

door

Wijnandus Franciscus Robertus Maria Koch geboren op 28 april 1969

te Tilburg 


\section{DIT PROEFSCHRIFT IS GOEDGEKEURD DOOR:}

Prof.dr. E. Marani, promotor 
DE PROMOTIECOMMISSIE IS ALS VOLGT SAMENGESTELD:

Promotor: Prof.dr. E. Marani

Referent: Prof.dr. J.D. van Gool

Leden: Prof.dr.ir. A.J. Mouthaan (voorzitter/secretaris)

Prof.dr.ir. P.H. Veltink

Prof.dr.ir. C.H. Slump

Prof.dr. O.P. Bleker

Prof.dr. B.L.H. Bemelmans

Prof.dr. J.A. Witjes

Paranimfen: Dr. S.D. Bos

T.A. Roeleveld 

“THERE IS NO CONSIDERABLE MUSCLE IN THE BODY WHOSE FORM AND FUNCTIONS ARE MORE DIFFICULT TO UNDERSTAND THAN THOSE OF THE LEVATOR ANI, AND ABOUT WHICH SUCH NEBULOUS IMPRESSIONS PREVAIL."

DiCKINSON (1889) 
De uitgave van dit proefschrift is mede mogelijk gemaakt door:

Universiteit Twente, leerstoel Biomedical Signal and Systems Foreest Instituut Alkmaar

Abbott

Astellas

sanofi aventis

Raadgevers Medische Beroepen 
Voor 'mijn' meiden 



\section{CONTENTS}

PART 1 - InTROduction

1 - INTRODUCTION AND Aim

1.1 - REVIEW OF THE LITERATURE 15

1.2 - The upper layer or Pelvic Diaphragm 16

1.3 - EMBRYOLOGY 19

1.4 - Materials And Methods 20

1.5 - AbBREVIATIONS 25

Part 2 - Fetal Period

$2.1-50 \mathrm{MM}, \pm 12$ WEEKS 28

2.2 - 43 MM AND 42 MM, \pm 10 WEEKS 37

2.3 - 34 MM AND 35 MM, \pm 9 WEEKS

Part 3 - Embryonal Period

3.1 - STAGE 23: 28 MM AND 30 MM, \pm 58-59 DAYS 56

3.2 - STAGE 21: 22 MM AND 23 MM, \pm 53-54 DAYS 65

3.3 - STAGE 20: 20 MM AND 21 MM, \pm 52 DAYS 74

3.4 - STAGE 18-19: 17 MM, \pm 49 DAYS

3.5 - STAGE 17 AND EARLIER

Part 4 - Summary and Conclusions

4 - General aspects 88

4.1 - Musculus OBtURATORIUS INTERnUS

4.2 - Musculus LeVATOR ANI 92

$\begin{array}{ll}4.3 \text { - Musculus COCCYGeus } & 97\end{array}$

4.4 - Clinical Implications 101

$\begin{array}{ll}\text { SAMENVATting } & 102\end{array}$

$\begin{array}{ll}\text { REFERENCES } & 109\end{array}$

PART 5 - Full COLOR Illustrations 114

$\begin{array}{lc}\text { Curriculum Vitae } & 124\end{array}$

$\begin{array}{ll}\text { DANKWOORD } & 127\end{array}$ 



\section{PART 1}

\section{- InTROduction AND Aim - REVIEW \\ - Materials and Methods}

\section{CONTENTS:}

1 - IntRoduction ANd Aim

1.1 - Review of the Literature

1.2 - The UPPer Layer or Pelvic diaphragm

1.2.1 - (ENDO)PELVIC FASCIAE

1.2.2 - LEVATOR ANI

1.3 - EMBRYOLOGY

1.4 - Materials and Methods

1.4.1 - Detailed OVERVIEW OF SERIES USED

1.4.2 - SEX TYPING

1.4.3 - 3D-RECONSTRUCTION

1.5 - ABBREVIATIONS 


\section{Introduction and aim}

A sound and detailed knowledge of the anatomy of the pelvic floor is of the utmost importance to gynecologists, obstetricians, surgeons, and urologists, since they all share the same responsibility in treating patients with different pathological conditions caused by pelvic floor dysfunction [Lawson 1974, Mostwin 1991, Klutke 1995, Haderer 2002]. The most common clinical expressions of pelvic floor dysfunction are urinary incontinence, anal incontinence, and pelvic organ prolapse (POP). Most often these clinical expressions are found in women, and they are briefly discussed below based on the outline presented in the Third International Consultation on Incontinence, a joint effort of the International Continence Society (ICS) and the World Health Organization (WHO) [Abrams 2005].

The prevalence of severe or 'significant' urinary incontinence ranges between $3 \%$ en $17 \%$, with stress urinary incontinence being the most common: approximately $50 \%$ of cases. Established potential risk factors are age, childbearing, and obesity. The pelvic floor plays an important role in these risk factors. There is evidence that the pelvic floor structures change with age, giving rise to dysfunction. Pregnancy, and especially vaginal delivery, may result in pelvic floor laxity as a consequence of weakening, stretching, and even laceration of the muscles and connective tissue, or due to damage to pudendal and pelvic nerves. Comparable to pregnancy, obesity causes chronic strain, stretching, and weakening of muscles, nerves, and other structures of the pelvic floor.

Conservative management of stress urinary incontinence focuses primarily on weight loss and physical therapy, both for prevention and treatment. Physical therapy can comprise pelvic floor muscle training, electrical stimulation, magnetic stimulation, and application of weight- ed vaginal cones. All are based on the principle of improving strength and/or timing of the pelvic floor muscle contraction. Surgical treatment aims to improve support of urinary sphincter and bladder neck, and is performed in the region of the urogenital diaphragm.

Anal incontinence is the involuntary loss of feces (solid or liquid) and flatus. Its prevalence increases with age, varying from $1.5 \%$ in children to more than $50 \%$ in nursing home residents, and it is almost as common in men as in women. Age is an important risk factor for anal incontinence, because of co-morbidity from surgery, progressive neurological disease, and stroke. Conflicting data exist for the role of childbirth and mode of delivery as risk factors. Other risk factors are iatrogenic factors: episiotomy or anal sphincter myotomy, for the treatment of anal fissures and hemorrhoids respectively.

Conservative treatments focus on patient education, dietary counseling, management of constipation, and pelvic floor muscle exercises with or without biofeedback. Non-conservative treatment can consist of either pharmacotherapy or surgery. When there is a sphincter defect, sphincteroplasty is performed. In the absence of sphincter defects, sacral nerve stimulation, dynamic graciloplasty, artificial sphincter implantation, or even a diversion can be considered. In contrast to urinary incontinence, the role of the pelvic floor appears to be limited in the management of anal incontinence, and treatment is mainly focused on the anal sphincter complex.

$\mathrm{POP}$ is defined as the downward descent of the pelvic organs, resulting in a protrusion of the vagina and/or the uterine cervix; it does not include rectal prolapse. It is a common condition, affecting $50 \%$ of parous women, with a $7 \%$ lifetime risk for undergoing surgery for prolapse by age 80 . Risk factors for developing POP are not well defined, but they include age, pregnancy, 
parity, obstetric factors, obesity, race, and gynecologic surgery. Pelvic floor muscle strength progressively decreases with increasing age and parity, and both vaginal childbirth and age have been implicated as major inciting events for pelvic neuropathy, causing POP as a consequence of the resulting pelvic floor dysfunction.

Conservative management of POP is aimed at increasing strength, endurance, and support of the pelvic floor muscles. The role of physical therapy in the treatment of POP, however, remains un-established. Non-conservative treatments focus on the actual reduction of prolapsing tissues, by resection or by repositioning the tissue to its original position (e.g. sacrocolpopexy).

Judged by the ever-increasing number of papers published in recent years, we believe that more and more attention is given to the physiological aspects of the pelvic floor in maintaining continence and support of pelvic viscera [Barbaric 2001, Olsen 2001, Abrams 2005]. Medical specialists appear to progressively realize the enormous advantage of a shared knowledge in their treatment of pelvic floor dysfunction. In this context, it is difficult to understand the striking disregard of medical science for, and unacquaintedness with, embryological anatomy and development of the pelvic floor. Up until today very little is published on this subject [Bitoh 2002, Fritsch 1992a/b, 1993, 1994a/b, van der Putte 2005].

Our aim is to describe the embryology of the human pelvic diaphragm muscles. A detailed description of the mesenchyme condensations, and the developing muscles originating from them, together with the circumference of their fasciae, will elucidate the differences of opinion on the subdivisions of the pelvic diaphragm muscles. We hope it will also help to improve the rationale of the many therapeutic avenues for pelvic floor dysfunction.

\subsection{Review of the literature}

In humans, the functions which the pelvic floor is called upon to perform differ widely from those in animals, in which the long axis of the body is horizontal rather than vertical. In humans, the weight of the abdominal and pelvic viscera is sustained mainly by the floor of the pelvic cavity, and accordingly this structure is specially modified [Thompson 1899, Marani 2002].

In most mammals the pelvic floor is largely sphincteric in action, to secure continence, as the ventral abdominal wall achieves the supportive function of the (pelvic) viscera. The muscular fibers, which form a distinct layer in the pelvic floor of mammals, are all situated around the rectal and genito-urinary canals, and the rest is made up of connective tissue and integuments [Thompson 1899].

In those mammals in which the long axis of the body is absolutely or approximately vertical (e.g. Homo sapiens) a great difference in the architecture of the pelvic floor is apparent. The outlet of the pelvic cavity is modified and adapted for supportive maintenance of pelvic and abdominal viscera. In addition to a layer of muscles with mainly sphincteric functions, a second layer has developed into a well-marked diaphragm, which constitutes a muscular and tendinous sheet attached to the inner circumference of the pelvis [Fritsch 1995, Occelli 2001, Pit 2003]. In this pelvic floor two distinct layers or diaphragms can be recognized, with contrasting arrangement and function. The upper or superior layer forms a more or less complete pelvic diaphragm (first so named by Meyer, in 1861), designed for purposes of support, and the inferior layer forms sphincters around the rectal and genito-urinary canal for purposes of maintaining continence. The sphincters around the genito-urinary canal are embedded in the urogenital diaphragm, and the rectal sphincters are a separate entity forming the rectal sphincter complex. The two layers are not only 
different in function but also in morphology. The existence of an embryologic (and consequentially also a neuro-anatomic) separation between the two layers of the pelvic floor has been discussed extensively in the medical literature [Marani et al 1993, Fucini, 1999, Marani 2002].

Although the muscles of the pelvic diaphragm are mainly responsible for supporting the viscera, the pelvic bones also have a supportive function [Marani, 2002]. Davies [1955] has suggested that when humans assumed an upright position, they did so by developing a lordotic curvature of the lumbar spine. When a human stands erect the abdominal axis becomes vertical, but the pelvic axis remains nearly horizontal. This supine posture has been shown to play a role in shaping the human pelvis [Abitbol, 1989]. Forces on the pelvic floor exerted by gravity and intraabdominal pressure are guided to the abdominal muscles and pubic bone, and via the ilial bones to the legs, leaving a lesser force to be supported by the pelvic diaphragm [Marani, 2002].

\subsection{The upper layer or Pelvic Diaphragm}

In the upper supportive layer the muscles are derived from the flexors and abductors of the caudal end of the vertebral column; evolutionary, these flexors and abductors have undergone retrogressive changes as the number of caudal vertebrae is reduced in the development to an upright position. Their function has been modified from moving a tail to supporting the viscera [Thompson 1899, Gray 1995].

The upper supportive layer is invariably known as the pelvic diaphragm, and can be divided into two separate layers: the endopelvic fascia and the muscles and fascias of the levatores ani. Its form is variably described as a 'basin' or a 'funnel' [Waldeyer 1899, Dickinson 1889, Marani 2002], or as a 'dome' [Hjartardottir, 1997]. The dif- ferences can well be explained by the fact that Waldeyer and Dickinson used cadavers for their studies, while nowadays functional studies can be performed by magnetic resonance imaging in living human subjects [Hjartardottir, 1997].

\subsection{1 (Endo)pelvic fasciae}

The endopelvic or pelvic fascia is a fibro-muscular layer consisting of collagen, elastin, and smooth muscle cells, forming a network of sheaths extending from the pelvic floor to the thoracic cavity [De Blok, 1982]. One of the greatest sources of confusion has been the attempt to show that it could be traced as one continuous layer over the entire pelvic contents [Barnes, 1921]. It anchors the post-natal pelvic organs (corpus pelvinum) to the pelvic wall by septa, extending from the pelvic wall to the organs [De Blok 1982, Marani 2002]. It comprises the parietal pelvic fascia and the visceral pelvic fascia.

The parietal pelvic fascia is part of the general layer covering the inner aspect of the abdominal and pelvic walls [Gardner, Gray and O'Rahilly, 1986], where it forms a part of the pelvic floor and lines the lateral walls of the pelvis (obturator fascia). The parietal pelvic fascia is arranged in two layers: a superior and an inferior fascia. The superior fascia forms the tendinous arch of the pelvic fascia [Pit, 2003], of which the most anterior part forms in fact the medial puboprostatic (pubovesical) ligaments (see further).

Posteriorly, this fascia is incomplete: it is absent in front of the sacrum, where a recto-sacral fascia is found [Havenga 1998, Marani 2002], thought to anchor the rectum to the sacrum and thus preventing prolapse. Its existence is denied by others [Fritsch, 1995]. The part of the parietal fascia covering the obturator internus muscle is called the obturator fascia, being attached around the margins of this muscle and covering its pelvic surface. This fascia thus consists of two layers: the superior fascia of the parietal pelvic fascia, and the fascia (or perimysium) of the internal ob- 
turator muscle itself. Below the level of the obturator canal, a thickening of the obturator fascia may be present, representing the line of fusion of the obturator fascia with the superior and inferior fascia of the pelvic diaphragm. It extends from the back of the body of the pubis to the ischial spine, giving origin to a part of the levator ani. It is known as the tendinous arch of the levator ani (or arcus tendineus levatoris ani). Barnes [1921] stated that in only $40 \%$ of cases the part of the levator ani called the iliococcygeal muscle in fact originates from this tendinous arch. In the other $60 \%$, the arcus tendineus levatoris ani was absent and the levator ani took origin from the arcus tendineus fasciae pelvis (the 'white line'), a tendinous arch stretching from the postero-inferior border of the pubic bone and symphysis to the ischial spine and sacro-iliac joint, forming a ' $Y$ ' [Pit, 2003]. This arch serves to fix the bladder and the prostate to the wall and floor of the pelvis, forming the puboprostatic ligaments and lateral true ligaments of the bladder [Derry, 1907]. It is in this sense important to keep in mind that the part of the obturator internus muscle below this tendinous arch is in fact extra pelvic.

The visceral pelvic fascia is formed by extraperitoneal tissue, variable in structure, serving as a packing for organs and as sheaths for vessels and nerves, connecting them to the parietal pelvic fascia and the inner aspect of the pelvic peritoneum. Some of these sheaths are called ligaments, supporting different endopelvic organs, and are described with the organs they are associated with [De Caro, 1998 and De Blok, 1982]. At the point where pelvic organs pass through the pelvic floor, the parietal and visceral pelvic fascias are continuous.

\subsubsection{Musculus levator ani}

The $\mathrm{m}$. levator ani (first called $\mathrm{m}$. sedem atollens, Vesalius 1555) is a broad muscular sheet of variable thickness attached to the internal surface of the true pelvis, i.e. the back of the body of the pubic bone, to the pelvic fascia on the sidewalls (tendinous arch of levator ani and pelvic fascia) and to the spine of the ischium. Its upper surface is covered by a distinct fascia, its inferior surface by a very thin fascia, better called a perimysium [Barnes, 1921].

The difference of opinion concerning the anatomy of the levator ani is well described by Dickinson [1889]: “..., there is no considerable muscle in the body whose form and functions are more difficult to understand than those of the levator ani, and about which such nebulous impressions prevail".

Some authors describe the levator ani as divided into two parts: the pubococcygeus and the iliococcygeus muscle [Elftman 1932, Thompson 1899, Waldeyer 1899]. Others include the puborectalis muscle and/or the coccygeus muscle with the levator ani [Mostwin, 1991], or typically exclude it [Shafik, 1975]. Difference of opinion exists about whether the two muscles are attached to or overlapping each other [Knauer 1914, Elftman 1932], or are demonstrably separate [Quain's Anatomy 1899, Lawson 1974, Waldeyer 1899]. Lartschneider [in Thompson, 1899] spoke of a 'portio pubica' and 'portio iliaca', indicating that the pubococcygeal and iliococcygeal muscles cannot be separated. Differences can also be noted in the origin of these two muscles: invariably the pubococcygeus arises from some part of the pubic bone, whereas the iliococcygeus originates from the 'white line' but can extend in front of the obturator canal to the pubic bone. The separation of pubococcygeus from iliococcygeus is then based on an imaginary line running from the anterior edge of the ischial tuberosity to the junction of the superior pubic ramus with the ilium [Thompson 1899, Holl 1897, Zacharin 1985]. Fritsch [1994a] showed that in human development the tendinous arch of the pelvic fascia plays an important role in the differentiation of pubococcygeus and iliococcygeus.

Lawson [1974] divided the levator ani 
muscles into two different functional groups, pubo-visceral and diaphragmatic, based on detailed studies of the pelvic floor in neonates and children. The pubo-visceral group is composed of muscles originating from the back of the pubic bone and inserting directly or indirectly into the pelvic viscera (Lawson describes puborectalis, pubo-analis, pubovaginalis and puboprostatic muscles). In addition to a supportive function these muscles can also move the viscera upwards and forwards. The diaphragmatic, or posterior, group has a simple supporting, diaphragmatic role. These muscles originate from the tendinous arch and ischial spine, forming a continuous sheet, which inserts via three main parts (pubococcygeus, iliococcygeus and coccygeus) into the anterior sacrococcygeal ligament and the bodies of the lower sacral and coccygeal vertebrae. The most anterior fibers curve back to form an inverted arch with the fibers from the opposite side.

Figure 1.1 shows an interpretation of the pelvic diaphragm divided in separate muscles, as described above. Others, like Thompson [1899], Holl [1897] and Zacharin [1985] describe the levator ani as one single muscle (Figure 1.2).

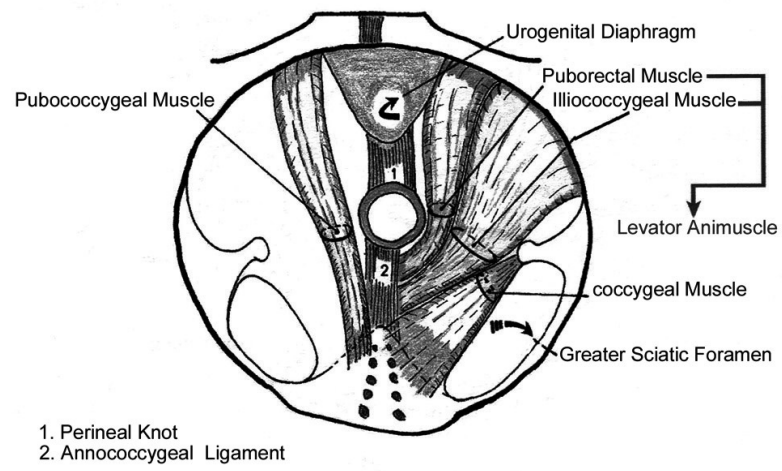

Figure 1.1

Schematic representation of the muscles of the pelvic diaphragm, as separate muscles. From Marani [2002], with permission. full color illustrations of the photos on this page can be found on page 114

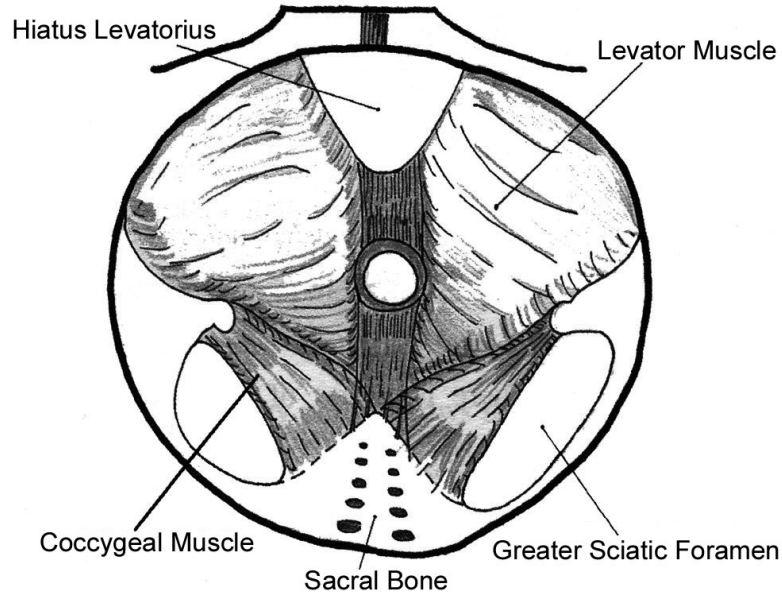

Figure 1.2

Schematic representation of the muscles of the pelvic diaphragm, as one single muscle. From Marani [2002], with permission.

\section{Musculus pubococcygeus}

The $\mathrm{m}$. pubococcygeus in man varies considerably as to division and structure. The most medial fibers originate near the pubic symphysis, and are in close apposition to the prostate in the male, and to the base of the bladder in the female. Behind the prostate, the medial fibers come in close contact with each other, eventually inserting in the rectum. A difference of opinion exists between anatomists whether these muscular fibers actually cross the midline at this point. Bryce [1923] describes the crossing of fibers within the perineal body whereas Delbet [1907] and Elftman [1932] describe smooth muscle fibers holding the two opposite pubococcygeus muscles together. The lateral fibers pass backward, to insert in the rectum, in the anococcygeal ligament, and in the coccyx [Elftman, 1932].

\section{Musculus puborectalis}

There is also a more superficial band of fibers originating near the pubic symphysis, encircling the pelvic viscera as a sling or inserting directly in to them. This band is referred to as the puborectalis muscle [Holl, 1897 and Piersol, 1930].

\section{Musculus iliococcygeus}

The $\mathrm{m}$. iliococcygeus appears to originate from 
the tendinous arch of the levator ani. Posteriorly it may originate from the tendinous arch of the fascia pelvis, but anteriorly the 'white line' occupies a lower level (it is interesting to see that some authors, for instance Piersol [1930], describe the 'white line' as being the tendinous arch of the levator ani). The iliococcygeus is directed downwards, backwards, and inwards, and attaches to the coccyx and the anococcygeal ligament. Its degree of development is variable. It may fail entirely, it may be replaced by fibrous tissue, or it may be strongly developed [Elftman 1932, Thompson 1899, Abitbol 1988]. Derry [1907] and Barnes [1921] state that the iliococcygeal muscle overlying the internal obturator muscle is replaced by aponeurotic tissue, when the muscle does not originate from the iliopectineal line but from a lower level. They thus describe the iliococcygeal muscle to originate from the iliopectineal line (i.e. linea arcuata or linea terminalis, being the most medial border of the ilium). However, in most cases it seems to originate from a lower level (the tendinous arches of levator ani or fascia pelvis), and the part covering the internal obturator muscle is thus thin and transparent. If muscular bundles are present, they are frequently separated by membranous intervals, leaving only support as function.

Sometimes another accessory muscle can be found, the $\mathrm{m}$. iliosacralis. This is in fact the posterior part of the iliococcygeus, which can be divided into a ventral and posterior part according to Holl [1897]. Usually, only the ventral (iliococcygeus) part persists [Thompson 1899].

\section{Musculus coccygeus}

The $\mathrm{m}$. ischiococcygeus or coccygeus muscle is variably described as a part of the levator ani [Quain 1899, Mostwin 1991], or as a single muscle [Waldeyer 1899, Piersol 1930]. Evolutionary it changed to a fibrous strand when the tail in humans disappeared, forming also most or part of the sacrospinous ligament [Elftman 1932,
Thompson 1899, Knauer 1914]. Occasionally it may persist as a muscle.

\subsection{Embryology}

Little is known about the embryology of the human $m$. levator ani. Power [1948] described the levator ani as the lower part of the rectus abdominis muscle, separated by the in-growth of the pubic bone.

Popowsky [1899] and Gegenbauer [1890] assumed that both the muscles of the urogenital diaphragm and the external anal sphincter are derived from the cloacal sphincter, a circular muscle surrounding the primitive cloaca, and fixed to symphysis, ischial spine, and sacrum. During the development of the perineal fold, the cloacal sphincter is divided in two separate sphincters, the ventral being the sphincter of the urogenital sinus, and the dorsal the external anal sphincter. According to Popowsky [1899], the urogenital diaphragm is derived from the sphincter of the urogenital sinus. A detailed overview of the embryology of the urogenital diaphragm and anal sphincters is beyond the scope of this review: Dorschner [2001] gives a detailed overview of the mature anatomy of the urogenital diaphragm, and van der Putte [2005] published an overview of the anal and perineal development.

The development of the pelvic diaphragm is still largely a mystery. One of the authors describing the development of the pelvic diaphragm is Popowsky [1899]. Due to extended defects in the material he worked with, he was unable to describe the early stages of the development of the levator ani. In the late stages of development he had to work with, the levator ani was divided in what he called a 'pars pubica' and a 'pars iliaca', and it could not be separated from the coccygeal muscle. According to Popowsky an extra argument for this 'lumping' was that the coccygeal and levator ani muscles share the 
same nerve supply (more then a century later, this shared innervation has been demonstrated again by Barber [2002]). This led Popowsky to believe that the levator ani is in fact a differentiation of the coccygeal muscle. Part of the muscle fibers of the coccygeus muscle migrate anteriorly towards the pubic bone, following the lateral borders of the small pelvis. Once these fibers reach the pubic region and attach to the developing bones, they radiate into parallel fibers extending to the pelvic organs. Coming across any muscle derived from the cloacal sphincter, the developing levator ani more or less attaches to these muscles.

Nearly a hundred years later, Fritsch [1994a] describes in her article the developmental characteristics of the levator ani in several stages, which will be discussed below.

At the beginning of the fetal period $\left(9^{\text {th }}\right.$ week of development), the anlage of the levator ani can already be recognized as consisting of three portions, separated by loose mesenchyme: pubococcygeus, iliococcygeus and puborectalis. There is a clear border of mesenchyme between the iliococcygeus and coccygeus muscles. The pubococcygeus and puborectalis originate in part from mesenchyme at the pelvic surface of the pubis, lateral to the symphysis. The iliococcygeus is attached to the lower coccygeal vertebrae, which have an acute angle with the sacral vertebrae. In 14-week old fetuses the funnel-shaped form of the pelvic diaphragm is already completed [Fritsch, 1994a].

In the second trimester of pregnancy (1928 weeks post conception), the differentiation of connective tissue has proceeded, and the pelvic fascia is clearly outlined. All points of insertion of the levator ani can be recognized at these stages. The pubococcygeus arises from the pubic bone and the anterior part of the obturator fascia. At a level where the tendinous arch of the pelvic fascia fuses with the obturator fascia, the iliococcygeus takes its origin. Differences between male and female pelvic diaphragm now become evident. In the female a small layer of connective and adipose tissue separates the levator ani from the pelvic organs. This layer is thin and already intermingled with connective tissue. In the male, the levator ani is a well-developed muscle.

During the entire fetal period, no muscle fibers of the levator ani can be seen radiating into the prostate, vagina, or rectum. This is in accordance with studies in adults performed by Levi [1991], who found the puborectalis, iliococcygeus, and pubococcygeus to have the same origin, never directly connected to the pelvic viscera or anal sphincters. In adults, Dickinson [1889] already could not find any fibers of the levator ani actually inserting in the pelvic viscera.

\subsection{Materials and Methods}

During prenatal development four consecutive stages can be discerned [Gribnau, 1981]:

(1) the presomite stages 1-8,

(2) the somite stages 9-12,

(3) the post-somite or organogenetic stages 13-23,

(4) the fetal stages.

From a survey published by Gribnau [1981] one can conclude that the development of the pelvic floor in humans takes place in the developmental (organogenetic) stages nr 13-23 (Table 1).

We have chosen the stages 13-23, based on the fact that in stage 14 a definite hind limb bud is present, and on Fritsch [1994a] describing the presence of the levator ani at nine weeks post-conception (this would be about stage 23). One can expect the pelvic floor to develop in that period. To fully complete the survey, we extended the period of interest to the early fetal period: up to embryos of $50 \mathrm{~mm}$ crown-rump length (CRL), 12 weeks post-conception.

In the past decennia, non-human primates have been used increasingly for research pur- 


\begin{tabular}{|l|l|l|}
\hline $\begin{array}{l}\text { Developmental } \\
\text { Stage }\end{array}$ & Age, days & CRL, mm \\
\hline 13 & $28-32$ & $4-6$ \\
\hline 14 & $31-35$ & $5-7$ \\
\hline 15 & $35-38$ & $7-9$ \\
\hline 16 & $37-42$ & $8-11$ \\
\hline 17 & $42-44$ & $11-14$ \\
\hline 18 & $44-48$ & $13-17$ \\
\hline 19 & $48-51$ & $16-18$ \\
\hline 20 & $51-53$ & $18-22$ \\
\hline 21 & $53-54$ & $22-24$ \\
\hline 22 & $54-56$ & $23-28$ \\
\hline 23 & $56-60$ & $27-31$ \\
\hline
\end{tabular}

Table 1

Embryonic age [O'Rahilly 1979] and crown-rump length (CRL) [Gribnau 1981] of the organogenetic stages in humans. Developmental stages will be used in the embryonic period.

poses in various scientific fields. Understandably, ethical issues prevent us from unlimited gathering of human embryonic material. Previous authors, especially Gribnau [1981], have extensively described the similarities in development between different species, making it possible to extrapolate scientific conclusions made in nonhuman primates tot humans.

We were lucky to study the development of the pelvic floor in humans (Homo sapiens), because an excellent series of sections of human embryos in every different organogenetic stage is held in the collection of the Department of Anatomy and Embryology of the Leiden University Medical Centre. The collection was initiated by the anatomist Dankmeijer and covers a period from the late fifties to the early nineties.

Use was made of 38 embryos, cut transversely. Almost all sections were $10 \mu \mathrm{m}$ thick and fixed in formaldehyde $4 \%$, after which they were stained with hematoxylin-eosin (HE) or Azan.

We were able to select embryos varying in CRL from $9.5 \mathrm{~mm}$ CRL (6 weeks post conception) to $50 \mathrm{~mm}$ CRL (12 weeks post conception), with small intervals, rendering a detailed overview of the entire organogenetic and early fetal period (Table 2).

Age in CRL is preferred over age in days or developmental stage, because this is the only direct information available in all embryos, allowing for comparison between our data and other studies. Age and stage are extrapolated using the data in Table 1.

The embryos and fetuses are described in a declining order of $C R L$, facilitating an exact identification of the muscles involved in the larger fetuses. Based on characteristics and developmental stage, the muscles can then be identified backwards, in the smaller fetuses en embryos. 


\begin{tabular}{|c|c|c|c|c|c|c|}
\hline CRL & Stage & WK & Series & Box & Staining & Sex \\
\hline $9.5 \mathrm{~mm}$ & 16 & 3122 & 56 & 20 & $\mathrm{HE}$ & \\
\hline $10 \mathrm{~mm}$ & 16 & 6320 & 163 & 61 & $\mathrm{HE}$ & \\
\hline $11 \mathrm{~mm}$ & 16 & 5118 & 113 & 47 & $\mathrm{HE}$ & \\
\hline $12 \mathrm{~mm}$ & 17 & 1453 & 45 & 15 & $\mathrm{HE}$ & \\
\hline $13 \mathrm{~mm}$ & 17 & 4756 & 98 & 41 & $\mathrm{HE}$ & \\
\hline $14 \mathrm{~mm}$ & 17 & 5569 & 144 & 57 & $\mathrm{HE}$ & \\
\hline $15 \mathrm{~mm}$ & 18 & 5442 & 136 & 55 & $\mathrm{HE}$ & \\
\hline $17 \mathrm{~mm}$ & 18 & 4132 & 91 & 35 & $\mathrm{HE}$ & male \\
\hline $17 \mathrm{~mm}$ & 18 & 5032 & 108 & 48 & $\mathrm{HE}$ & male \\
\hline $17 \mathrm{~mm}$ & 18 & 359 & 11 & 2 & $\mathrm{HE}$ & male \\
\hline $17 \mathrm{~mm}$ & 18 & 7435 & 207 & 76 & HE/Azan & male \\
\hline $18 \mathrm{~mm}$ & 19 & 7904 & 277 & 100 & HE & \\
\hline $18 \mathrm{~mm}$ & 19 & 13 & 20 & 3 & $\mathrm{HE}$ & \\
\hline $18 \mathrm{~mm}$ & 19 & 4657 & 104 & 34 & $\mathrm{HE}$ & \\
\hline $20 \mathrm{~mm}$ & 20 & 7996 & 297 & 107 & $\mathrm{HE}$ & \\
\hline $20 \mathrm{~mm}$ & 20 & 7262 & 203 & 74 & $\mathrm{HE}$ & \\
\hline $20 \mathrm{~mm}$ & 20 & 7993 & 294 & 104 & $\mathrm{HE}$ & male \\
\hline $20 \mathrm{~mm}$ & 20 & 1423 & 50 & 17 & $\mathrm{HE}$ & \\
\hline $21 \mathrm{~mm}$ & 20 & 5578 & 146 & 58 & $\mathrm{HE}$ & \\
\hline $21 \mathrm{~mm}$ & 20 & 2287 & 51 & 17 & $\mathrm{HE}$ & \\
\hline $21 \mathrm{~mm}$ & 20 & 8071 & 305 & 107 & $\mathrm{HE}$ & \\
\hline $22 \mathrm{~mm}$ & 21 & 5121 & 114 & 48 & $\mathrm{HE}$ & \\
\hline $22 \mathrm{~mm}$ & 21 & 7489 & 214 & 84 & $\mathrm{HE}$ & \\
\hline $22 \mathrm{~mm}$ & 21 & 7832 & 262 & 96 & $\mathrm{HE}$ & \\
\hline $22 \mathrm{~mm}$ & 21 & 7995 & 296 & 107 & $\mathrm{HE}$ & \\
\hline $23 \mathrm{~mm}$ & 21 & 548 & 30 & 8 & $\mathrm{HE}$ & \\
\hline $23 \mathrm{~mm}$ & 21 & 5249 & 126 & 51 & $\mathrm{HE}$ & \\
\hline $23 \mathrm{~mm}^{*}$ & 21 & 1256 & 47 & 15 & $\mathrm{HE}$ & male \\
\hline $25 \mathrm{~mm}$ & 22 & 107 & 7 & 3 & Azan & \\
\hline $25 \mathrm{~mm}$ & 22 & 5860 & 195 & 71 & HE/Azan & \\
\hline $28 \mathrm{~mm}$ & 23 & 7629 & 236 & 88 & HE & \\
\hline 28 mm* & 23 & 1451 & 71 & 24 & $\mathrm{HE}$ & female \\
\hline $30 \mathrm{~mm}$ & 23 & 7652 & 239 & 90 & $\mathrm{HE}$ & female \\
\hline 34 mm* & fetal & 1438 & 61 & 30 & $\mathrm{HE}$ & female \\
\hline $35 \mathrm{~mm}$ & fetal & 7608 & 229 & 83 & $\mathrm{HE}$ & female \\
\hline $42 \mathrm{~mm}$ & fetal & 2322 & 74 & 28 & $\mathrm{HE}$ & female \\
\hline $43 \mathrm{~mm} *$ & fetal & 4409 & 100 & $43 / 45$ & $\mathrm{HE}$ & female \\
\hline 50 mm* & fetal & 3083 & 57 & $21 / 22$ & $\mathrm{HE}$ & female \\
\hline
\end{tabular}

\section{Tabel 2}

Survey of series of sections of human embryos. In boldface are the embryos described in part two and three. The other embryos are used as reference, to exclude inter-embryonic variation. Sex typing was only performed when necessary for the description of the embryos. All embryos are cut in $10 \mu \mathrm{m}$ sections. The embryonic stage is extrapolated from the data presented in Table 1 . The reconstructed embryos are marked with an asterisk. WK is the abbreviation for 'work card', with the identification number of the embryo. 


\subsubsection{Detailed overview of series used}

At the Department of Anatomy and Embryology of the Leiden University Medical Centre large series of embryos of different species have been collected throughout the years and archived in detail. Of most of the series a small file is kept of important observations and of the preparations made of the embryos. What follows is a description of these files for some of the embryos used. Identification by WK-numbers of Table 2

3122 Human embryo with a CRL of $9.5 \mathrm{~mm}$. Originally fixed in alcohol of unknown concentration and after arrival at the department fixed in formaldehyde $4 \%$ (1962). Complete with umbilical cord and placenta. Cut in $10 \mu \mathrm{m}$ sections transversely and stained with $\mathrm{HE}$.

6320 Human embryo with a CRL of $10 \mathrm{~mm}$. First pregnancy of a 25-year-old woman. Fixed according to Bouin (1978), cut in $10 \mu \mathrm{m}$ sections transversely, and stained with $\mathrm{HE}$.

5118 Human embryo with a CRL of $11 \mathrm{~mm}$. Tubal pregnancy. The embryo was immediately fixed after operative removal from the Fallopian tube in formaldehyde $4 \%$ (1971). The material appeared in exceptionally good condition. Cut transversely in $10 \mu \mathrm{m}$ sections and stained with HE.

1453 Human embryo with a CRL of $11 \mathrm{~mm}$. Fixed in alcohol (1957), cut in $10 \mu \mathrm{m} \mathrm{sec-}$ tions and stained with $\mathrm{HE}$.

4756 Human embryo with a CRL of $13 \mathrm{~mm}$. Appearance is slightly macerated. Complete with fetal membranes. Fixed in formaldehyde 4\% (1970) after removal of the membranes. Cut transversely in 10 $\mu \mathrm{m}$ sections and stained with $\mathrm{HE}$.
5569 Human embryo with a CRL of $14 \mathrm{~mm}$. Aborted second pregnancy of a 24-yearold woman. Microscopically very slightly macerated. Fixed in formaldehyde 4\% (1973) and cut transversely in $10 \mu \mathrm{m} \mathrm{sec}-$ tions. Stained with HE.

5442 Human embryo with a CRL of $15 \mathrm{~mm}$. Macroscopically in excellent condition. Tubal pregnancy. After removal fixed in formaldehyde $4 \%$ and cut transversely in $10 \mu \mathrm{m}$ sections (1973). Stained with HE.

7435 Human embryo with a CRL of $17 \mathrm{~mm}$. Embryo of a 28-year-old female, complete within the embryonic membranes. Fixed in formaldehyde 4\% (1987) and cut transversely in $10 \mu \mathrm{m}$ sections. Stained with $\mathrm{HE}$ and Azan alternately.

4657 Human embryo with a CRL of $18 \mathrm{~mm}$. Present in an extirpated uterus of a 43 year old woman. Complete with placenta and fetal membranes. After opening of the membranes removal of the embryo and fixation in Bouin and alcohol $80 \%$ one day after surgery (1970). Cut transversely in $10 \mu \mathrm{m}$ sections and stained with $\mathrm{HE}$.

7996 Human embryo with a CRL of $20 \mathrm{~mm}$. Macroscopically of excellent quality with only minor skin lacerations in the cervical region. Fixed in formaldehyde 4\% (1991) and cut transversely in $10 \mu \mathrm{m}$ sections. Stained with $\mathrm{HE}$.

5578 Human embryo with a CRL of $21 \mathrm{~mm}$. Fixed in formaldehyde 4\% (1974) and cut transversely in $10 \mu \mathrm{m}$ sections. Stained with HE. 
7832 Human embryo with a CRL of $22 \mathrm{~mm}$. Fixed in formaldehyde 4\% (1990) and cut transversely in $10 \mu \mathrm{m}$ sections. Stained with $\mathrm{HE}$.

5249 Human embryo with a CRL of $23 \mathrm{~mm}$. Aborted pregnancy of a 29 year old woman. Fixed in formaldehyde $4 \%$, cut transversely in $10 \mu \mathrm{m}$ sections and stained with $\mathrm{HE}$.

5860 Human embryo with a CRL of $25 \mathrm{~mm}$. Fixed in formaldehyde 4\% (1975) and transversely cut in $10 \mu \mathrm{m}$ sections. Stained with HE and Azan alternately.

7629 Human embryo with a CRL of $28 \mathrm{~mm}$. Fixed in formaldehyde 4\% (1989) and transversely cut in $10 \mu \mathrm{m}$ sections. Stained with $\mathrm{HE}$.

7652 Human embryo with a CRL of $30 \mathrm{~mm}$. Fixed in formaldehyde 4\% (1989) and transversely cut in $10 \mu \mathrm{m}$ sections. Stained with $\mathrm{HE}$.

1438 Human embryo with a CRL of $34 \mathrm{~mm}$. Fixed in formaldehyde 4\% (1957) and transversely cut in $10 \mu \mathrm{m}$ sections. Stained with HE.

7608 Human embryo with a CRL of $35 \mathrm{~mm}$. Fixed in formaldehyde 4\% (1988) and transversely cut in $10 \mu \mathrm{m}$ sections. Stained with $\mathrm{HE}$.

4409 Female human embryo with a CRL of 43 $\mathrm{mm}$. Fixed in formaldehyde 4\% (1969) and cut transversely in $10 \mu \mathrm{m}$ sections. Stained with HE and Azan alternately.

\subsubsection{Sex typing}

In 1961, Lyon outlined the X-inactivation, or what is commonly known as the Lyon hypothesis. It states that:

(1) only one of the X chromosomes is genetically active;

(2) the other X chromosome of either maternal or paternal origin undergoes heteropyknosis and is rendered inactive;

(3) inactivation of either the maternal or paternal $X$ chromosome occurs at random among all the cells of the blastocyst on or about the sixteenth day of embryonic life;

(4) inactivation of the same $X$ chromosome persists in all the cells derived from each precursor cell [Cotran, 1999].

The inactive $X$ chromosome can be identified in the nucleus of a cell in interphase. It appears as a darkly staining small mass in contact with the nuclear membrane. It is also known as the Barr body or X chromatin. Barr bodies are present in all somatic cells of normal females, but they are most readily demonstrated in smears of buccal squamous epithelial cells. Barr bodies can also be demonstrated in extra embryonic membranes at about day 12 (presomite stage) of gestation [Miller, 1996]. X inactivation occurs during the early embryogenesis in a developmentally regulated manner. It occurs first in the extra-embryonic trophectoderm and is nonrandom. The paternal X chromosome is exclusively inactivated. Later, in the embryo itself, random inactivation of either the maternal or paternal $\mathrm{X}$ chromosome occurs.

Since Barr bodies can thus be identified in embryo's from the sixteenth day of gestation (presomite stage 7), demonstrating these inactive $\mathrm{X}$ chromosomes in the embryo's we used for our study, can reveal the gender of the embryo. For this, we located suitable cells in all embryos (if possible the oral cavity) to look for $\mathrm{X}$ chromatin near the nuclear membrane of the cells. 
Demonstrating a Barr body shows the embryo being female, lacking a Barr body shows the embryo being male. This specific sex typing was only performed in embryos not directly recognizable as male or female by the microscopic appearance of the internal genitalia (i.e. the undoubted presence or absence of a developing uterus, or the appearance of the mesonephric and paramesonephric ducts), only when necessary for the description of the embryos, or to study the presence of a sextype dependent pelvic diaphragm.

\subsubsection{D-reconstruction}

All embryo's used in this study were digitally photographed using an Olympus digital 1.2 Megapixel camera (Olympus BH-2, Olympus Optical Company Europe, Germany) mounted on an Olympus light microscope (Olympus DP-10, Olympus Optical Company Europe, Germany). The photographs were stored on compact disc at maximum resolution.

The commercially available Surfdriver 3.5.6 software (joint venture of the University of Hawaii, USA and the University of Alberta, Canada; www.surfdriver.com) was used to make three-dimensional reconstructions of the pelvis and pelvic diaphragm of the embryos. With this software, it is possible to trace the outlines of each slice, and then automatically stack the traces for a three-dimensional image. Adjustment of the traced slices is performed manually.

For reconstruction purposes, only the actual muscle volume of the pelvic diaphragm muscles has been reconstructed, without fascia or ligaments. The pelvis has been reconstructed following the contours of the cartilage present, disregarding cartilaginous lines between different developing bones, and disregarding mesenchymal formations. This means that the pelvis as reconstructed in this study appears to be constituted of two ossa coxae, while in fact the os coxa has not yet formed out of the three separate bones (os pubis, ischii and ilium), which can be identified as such in the actual fetus.

\subsection{Abbreviations}

ATLA: arcus tendineus levatoris ani

CRL: crown-rump length

HE: hematoxylin-eosin

POP pelvic organ prolaps 


\section{PART 2}

\section{Fetal Period}

CONTENTS:

2.1 - $50 \mathrm{MM}, \pm 12$ WEEKS

2.2 - 43 MM AND 42 MM, \pm 10 WEEKS

2.3 - 34 MM AND 35 MM, \pm 9 wEEKS 


\section{$2.150 \mathrm{~mm}($ WK 3083), \pm 12 weeks}

\subsubsection{General features}

This fetus with a CRL of $50 \mathrm{~mm}$ is about 12 weeks post conception. It is cut transverse in $10 \mu \mathrm{m} \mathrm{sec}-$ tions and stained with HE (see Table 2).

From the appearance of the internal pelvic organs it is apparent that this is a female fetus as a uterus and two ovaries can be clearly identified in the sections through the pelvic organs. Figure $50 \mathrm{~mm} .1$ also shows the other pelvic organs, i.e. the bladder, rectum and ureters. Together they form a corpus pelvinum that is surrounded by an integument of loose connective tissue and fat, interrupted by seemingly empty spaces caused by the peritoneal folds forming the uterovesical and rectouterine pouch. The peritoneum (visceral and parietal) cannot be identified as such.

The development of the bony pelvis is nearly complete. The separately developing bones are outlined in cartilage and no ossification is seen. The left and right os pubis meet, forming the symphysis pubica. Ramus superior and inferior of the os pubis are fully developed forming the foramen obturatum with the corpus and ramus ossis ischii dorsally. In this fetus the corpus ossis ilii, corpus ossis ischii and corpus ossis pubis can still be identified individually. Together with the already developed labrum glenoidale they are forming the acetabulum. The acetabulum can be seen as the centre of the os coxae that is formed by the os ilium, os ischii and the os pubis. The tuber ischiadicum and spina ischiadica of the os ischii are present as mesenchymal condensations and not as cartilaginous tissue. The ala ossis ilii shows a cartilaginous development centrally. The crista iliaca superiorly, the tuberositas iliaca dorsally and the spina iliaca anterior superior ventrally are not present.

The os sacrum of this fetus is fully developed in cartilage; fusion of the vertebrae is not yet present. Connection of the os sacrum to the os coxae is formed through ligaments attaching the pars lateralis of the os sacrum to the os coxae at the level of the future sulcus paraglenoidalis. These ligg. sacroiliaca interossea can be identified as such. Thus formation of the sacroiliac joint is present. The os coccygis is formed in cartilage and shows fusion of the third tot fifth vertebra. It is after reconstruction of the cartilaginous pelvis of this fetus that it became apparent that the typical lordotic angle at the level of the promontorium is not visible and that the os coccygis makes a sharp angle ventrally. Absence of the angle at the level of the promontorium and the sharp angle of the os coccygis seems responsible for the ventral position of the pelvic outlet present in this fetus. This ventral position of the pelvic outlet means that a caudal position in this fetus is in fact a dorsal position in the adult situation (see Figure $50 \mathrm{~mm} .11)$.

\subsubsection{Musculus obturatorius internus}

The $\mathrm{m}$. obturatorius internus forms an important landmark in the identification of the muscles of the pelvic diaphragm. In adults it is a large and clearly outlined muscle covering the os ischii and foramen obturatum. It originates from the ramus superior ossis pubis up to the sacroiliac joint, the ramus inferior ossis pubis and the ramus ossis ischii (surrounding the margins of the foramen obturatum). It runs dorsally through the incisura ischiadica minor, leaving the pelvic cavity to insert at the medial surface of the trochanter major femoris proximal to the fossa trochanterica.

In this fetus the $\mathrm{m}$. obturatorius internus is in all respects comparable to the adult situation. It can be seen originating from the medial aspect of the ramus superior ossis pubis, the ramus inferior ossis pubis and ramus ossis ischii covering the foramen obturatum and corpus ossis ischii. It can also be seen leaving the pelvic cavity to insert in the trochanter major femoris. Laterally the fetal $\mathrm{m}$. obturatorius internus is separated from the foramen obturatum by a thin layer of connective tissue; the membrana obturatoria. At the other side 
of the membrana obturatoria the $\mathrm{m}$. obturatorius externus can be identified clearly.

The nervus obturatorius is leaving the pelvis, nearly completely surrounded by the $\mathrm{m}$. obturatorius internus, through the canalis obturatorius. Only the superior margin of the canalis obturatorius is formed by cartilage, i.e. the ramus superior ossis pubis.

Just below the canalis obturatorius there is a dense band of connective tissue almost immediately covering more than half of the medial aspect of the $\mathrm{m}$. obturatorius internus and extending further dorsally from the inner opening of the canalis obturatorius. This is the developing arcus tendineus levatoris ani (ATLA). Ventrally it is fixed to the inner aspect of the ramus inferior ossis pubis just laterally of the symphysis pubica. Here it comes in to close contact with a small, dens band of connective tissue arising from the middle of the symphysis extending around the urogenital sinus; the developing pubovesical ligament and endopelvic fascia (see Figure $50 \mathrm{~mm} .2$ ). Dorsally the ATLA disappears in loose connective tissue. Following this arcus caudally it smoothly changes in muscular fibers: the m. levator ani.

\subsubsection{Musculus levator ani}

At both the left and right side of the pelvis the levator ani develops and shows a gradually increasing thickening as it progresses caudally. It's muscular fibers show an almost right-angled orientation to the ATLA. From the moment the levator ani originates, it is clear that it is a single muscle. Near it's origin at the level of the ATLA it comes into close contact with the inner aspect of the ramus inferior ossis pubis, only separated from it by a small border of connective tissue. Dorsally the levator ani extends over about half of the medial aspect of the $\mathrm{m}$. obturatorius internus fading away in connective tissue. As soon as the levator ani originates from the ATLA it is separated from the $\mathrm{m}$. obturatorius internus by a narrow space. On the medial side of the levator ani a small border of connective tissue (no fat) separates the muscle from the urogenital organs.

Progressing caudally the thickness of the levator ani increases, especially on the ventral side. The distance between the ramus inferior ossis pubis and the ventral side increases and the developing arcus tendineus levator ani starts to extend dorsally to the most dorsal part of the corpus ossis ischii covering the $\mathrm{m}$. obturatorius completely.

At the lower level of the foramen obturatum the levator ani has developed to a muscle completely covering the $\mathrm{m}$. obturatorius internus, almost fixed to the dorsal end of the corpus ossis ischii (the developing spina ischiadica). The decreasing ventral-dorsal length of the $\mathrm{m}$. obturatorius internus also attributes to this covering. On the ventral side the levator ani comes into close contact with the hind side of the urogenital sinus, but is not fixed to it. On the dorsal side the levator ani extends further away from the rectum. At this level a third muscle appears at the most dorsal part of the corpus ossis ischii. This is the m. coccygeus that will be discussed later on (see Figure 50mm.3).

Progressing even further caudally through the serial sections and coming behind the urogenital sinus it appears that the levator ani has retracted from it's attachment to the corpus ossis ischii. The dorsal end of the levator ani now lies more closely to the rectum without touching it and away from the corpus ossis ischii. The ventral side of the levator ani makes contact with a dens structure of connective tissue that crosses the midline just in front of the rectum to contact the ventral side of the levator ani on the other side of the pelvis. This structure is identified as the developing centrum tendineum (see Figure 50mm.4). At the level of the developing centrum tendineum no muscle fibers can actually be seen crossing the midline.

Further on, behind the centrum tendineum, the sphincter complex of the rectum be- 
comes visible with a $\mathrm{m}$. sphincter ani externus and internus. The ventral side of the levator ani, which now lies adjacent to the rectum, is fixed to the $\mathrm{m}$. sphincter ani externus, i.e. the deep part of the external sphincter. The rest of the levator ani is still one single muscle on the left and right side of the rectum without being attached to it (Figure 50mm.5).

Just behind the rectum the left and right levator ani are nearing each other in the midline. They are still separated by a structure of dense connective tissue that connects the left and right levator ani to the sphincter complex of the rectum (Figure 50mm.6). This structure is the developing ligamentum or raphe anococcygeum. It does not contain muscle fibers. Further caudally the left and right levator ani disappear still as separate muscles into the ligamentum anococcygeum that can be identified until its insertion in the tip of the os coccygis.

\subsubsection{Musculus coccygeus}

At the surface of the most dorsal part of the corpus ossis ischii, above the developing tuber ischiadicum, the origin of the $m$. coccygeus can be identified. This is also the point where the ATLA is attached to the corpus ossis ischii and just dorsal of the insertion of the $\mathrm{m}$. obturatorius internus onto the corpus ossis ischii. This point is the future spina ischiadica. The origin of the $m$. coccygeus extends to the developing tuber ischiadicum.

More caudally the $\mathrm{m}$. coccygeus starts to extend dorsally and expand towards the os sacrum. At a level just below the developing tuber ischiadicum it becomes apparent that the $\mathrm{m}$. coccygeus is divided into a dorsal en ventral part by a structure that appears to be a nerve and blood vessels (Figure $50 \mathrm{~mm} .7$ ). When following this structure it appears to be a branch from the nervus pudendus that runs medial from the developing tuber ischiadicum and lateral from the $m$. coccygeus. This branch has to be (one of) the innervating nerve of the $\mathrm{m}$. coccygeus. Nearly all the way up to the insertion of the m. coccygeus onto the os sacrum this division of the muscle in a ventral and dorsal part can be seen (Figure $50 \mathrm{~mm} .6)$. There can be no other explanation then that this dorsal part of the m. coccygeus is in fact the future ligamentum sacrospinale. This would explain the close relationship of the $\mathrm{m}$. coccygeus with the ligamentum sacrospinale in adults. Following the insertion of the $\mathrm{m}$. coccygeus onto the os sacrum more caudally the dorsal part disappears after its insertion onto the os sacrum. The ventral part continues to travel caudally towards what appears to be the last sacral vertebra and the first coccygeal vertebra. The insertion of the ventral part of the m. coccygeus into the os coccygis cannot be seen. The muscle is lost in dense connective tissue (lig. intervertebrale) before ending onto the os coccygis.

The ventral part of the $\mathrm{m}$. coccygeus travels towards the midline, following it caudally through the fetal pelvis, where it points towards the future ligamentum anococcygeum. The $\mathrm{m}$. coccygeus can also be traced much more caudally then the $\mathrm{m}$. levator ani and it never comes into contact with the levator ani. There is always a distinct border of loose connective tissue between the dorsal end of the levator ani and the ventral end of the $\mathrm{m}$. coccygeus.

\subsubsection{Musculus sacrococcygeus ventralis}

In front of the os sacrum on the medial aspect of the $\mathrm{m}$. coccygeus another muscle is identified in this fetus, both on the left and the right side (Figure $50 \mathrm{~mm} .8$ ). It originates medial on the inner aspect of the os sacrum and can be followed caudally towards the os coccygis were it inserts on the lateral aspect of the last coccygeal vertebrae. This muscle is the m. sacrococcygeus. Its muscular fibers are directed in such a way that the function of this muscle is to move the os coccygis ventrally: 'the tail between the legs'. As the os coccygis in humans can be seen as a rudimentary tail, it is likely that the $\mathrm{m}$. sacrococcygeus has dis- 
appeared in most cases. Only in some anatomic handbooks [Sobotta, Atlas of Human Anatomy, 1982] the m. sacrococcygeus is described as an existing muscle, leaving it undescribed in others [Gardner, Gray, O’Rahilly, 1986]. The m. sacrococcygeus is a rudimentary muscle, variably present in adult humans.

In between the left and right $m$. sacrococ- cygeus, just in front of the arteria and vena sacralis mediana, a structure of connective tissue appears that seems to originate from the midline of the os sacrum. It inserts on the os coccygis and ligamentum anococcygeum. This has to be either the ligamentum sacrococcygeum ventrale or continuing fibers of the ligamentum anococcygeum (Figure 50mm.8).
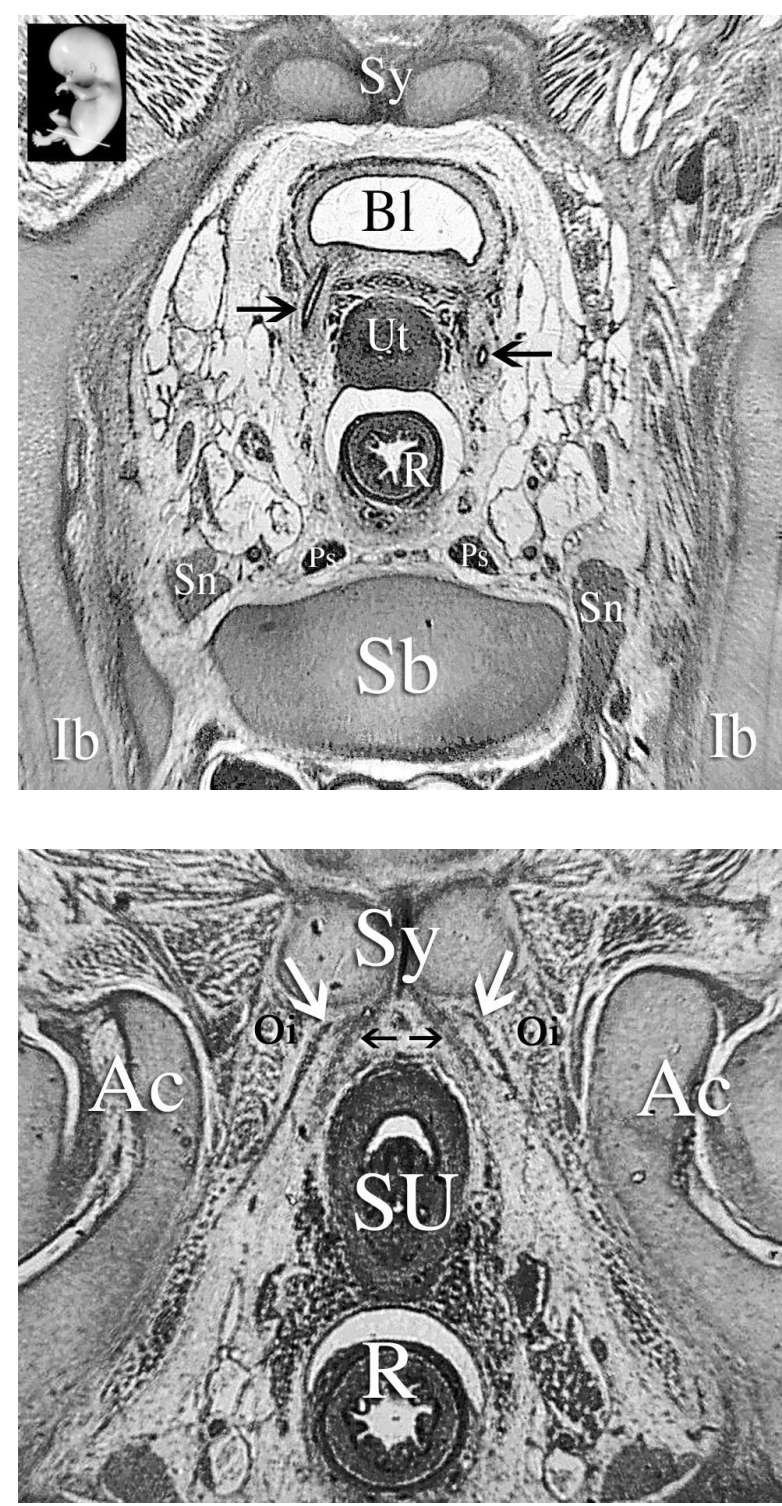

Figure 50mm.1

Insert: level of section indicated by a white line.

BI, bladder; Ib, os ilium; Ps, plexus sacralis; $\mathbf{R}$, rectum; $\mathbf{S b}$, os sacrum; $\mathbf{S n}$, nervus sacralis I; $\mathbf{S y}$, symphysis pubica; $\mathbf{U t}$, uterus; black arrow, ureter.

The intramural part of the left ureter is well visible. Between the uterus and the rectum the rectouterine pouch is identified as a seemingly empty space (cavum Douglasi). On the right side the first sacral nerve can be seen originating from the spinal cord and passing through the foramen sacralis I. Between the dorsal part of the left os ilium and the os sacrum the pars lateralis of the os sacrum forms the sacroiliac joint.

Figure 50mm.2

Ac, acetabulum; Oi, m. obturatorius internus; $\mathbf{S U}$, sinus urogenitalis; Sy, symphysis pubica; $\mathbf{R}$, rectum; black arrow, endopelvic fascia and pubovesical ligament; white arrow, arcus tendineus levatoris ani (ventral part near os pubis).

Note the close relationship of the ATLA and the endopelvic fascia together with the pubovesical ligament, anchoring the urogenital sinus to the os pubis and pelvic diaphragm. 


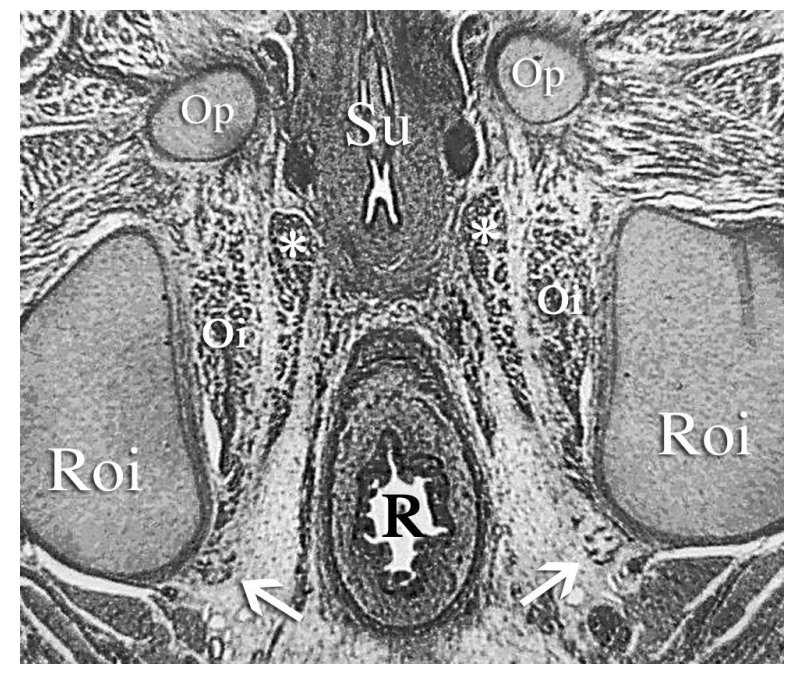

\section{Figure 50mm.3}

$\mathbf{O i}$, m. obturatorius internus; $\mathbf{O p}$, os pubis (ramus inferior); $\mathbf{R}$, rectum; Roi, ramus ossis ischii; $\mathbf{S u}$, sinus urogenitalis; white arrow, m. coccygeus; *, m. levator ani.

Note that the $\mathrm{m}$. levator ani lays completely separated from the sinus urogenitalis, the $\mathrm{m}$. obturatorius internus and rectum. Dorsally it has a continuation towards the ramus ossis ischii. This continuation is in fact the ATLA. It inserts on the surface of the os ischii together with the $\mathrm{m}$. obturatorius internus and the origin of the $\mathrm{m}$. coccygeus.
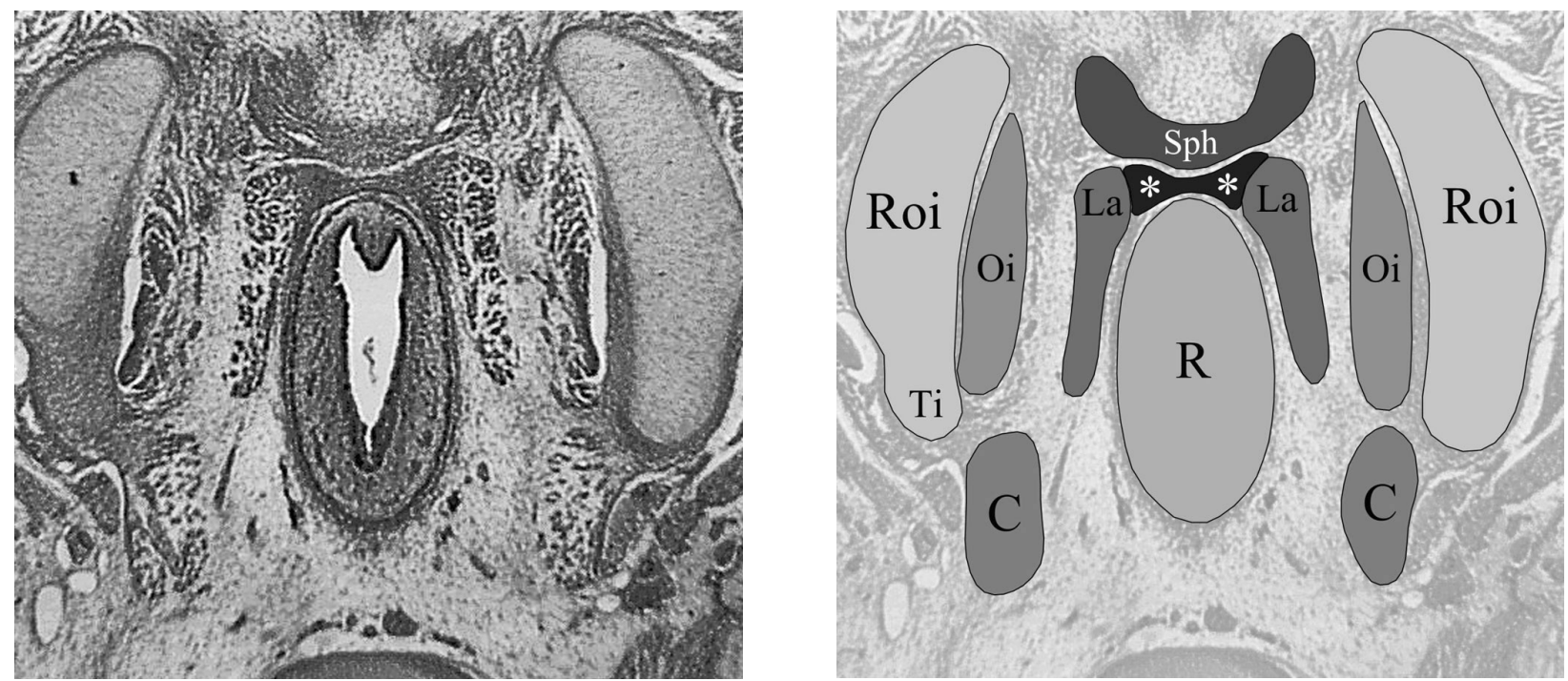

Figure $50 \mathrm{~mm} .4$ Photograph of a section at a level between the sinus urogenitalis and rectum

C, m. coccygeus; La, m. levator ani; Oi, m. obturatorius internus; R, rectum; Roi, ramus ossis ischii; Sph, m. sphincter ani externus (superficial part); Ti, tuber ischiadicum; *, m. sphincter ani externus (deep part). The levator ani is attached to the deep part of the external sphincter at the level of the perineum. The levator ani is nowhere attached to the rectum. This picture shows that the external sphincter is in fact the only muscle present in the midline of the pelvic diaphragm. Left and right levator ani are attached to each other by the deep part of the external sphincter, neither of them actually crosses the midline nor do they show any direct contact. 

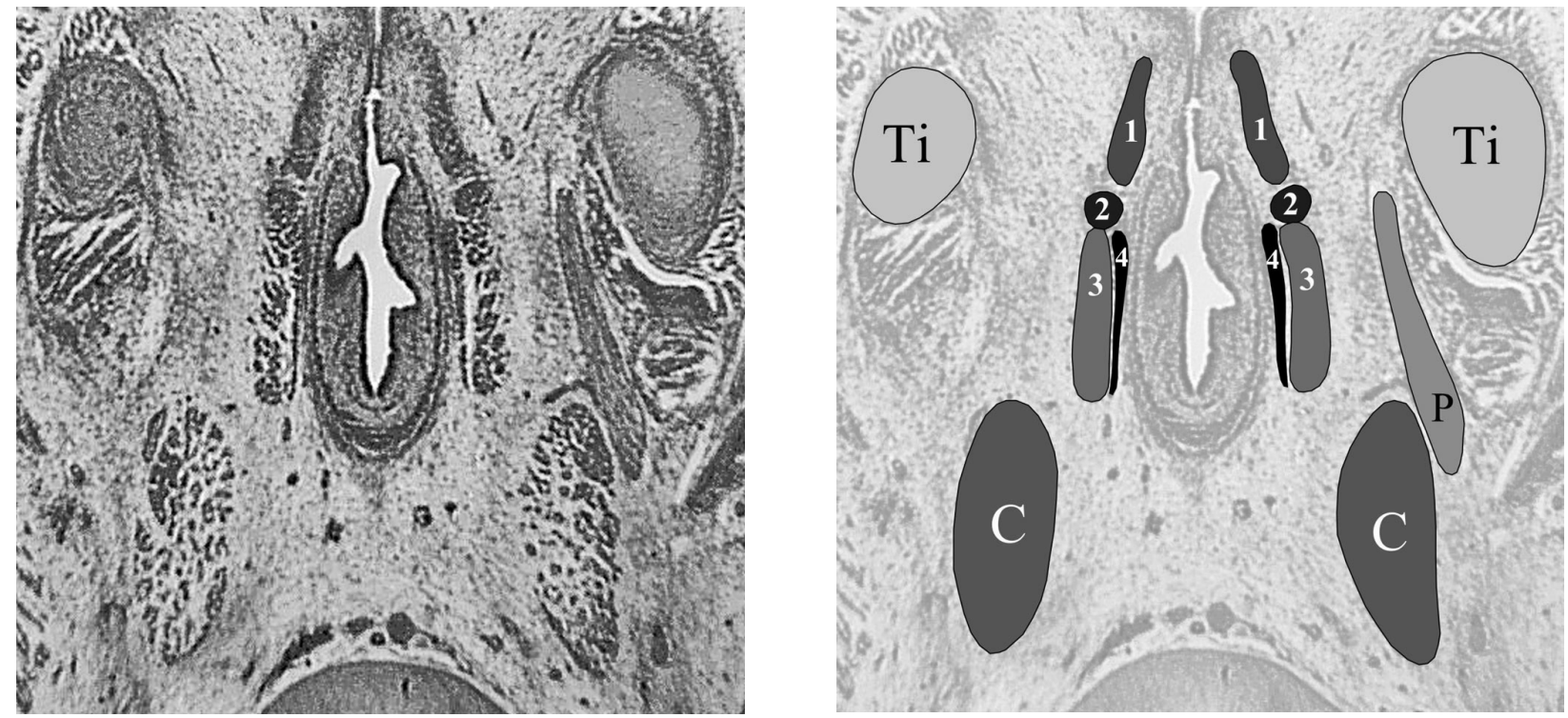

Figure 50mm.5 Photograph of a section at a level right through the anal canal.

$\mathbf{C}$, os coccygeus; $\mathbf{P}$, nervus pudendus; $\mathbf{T i}$, tuber ischiadicum; $\mathbf{1}$, superficial part of $\mathrm{m}$. sphincter ani externus; $\mathbf{2}$, deep part of musc. sphincter ani externus; $\mathbf{3}, \mathrm{m}$. levatoris ani; $\mathbf{4}$, developing longitudinal ligament. Again it becomes clear that the levator ani is attached to the deep part of the external sphincter as it passes alongside the rectum. There is no attachment to the rectum nor the internal sphincter. The left $\mathrm{m}$. coccygeus shows its subdivision in a ventral and dorsal part. The dorsal part becomes the ligamentum sacrospinale (see Figure 50mm.6 and 50mm.7)
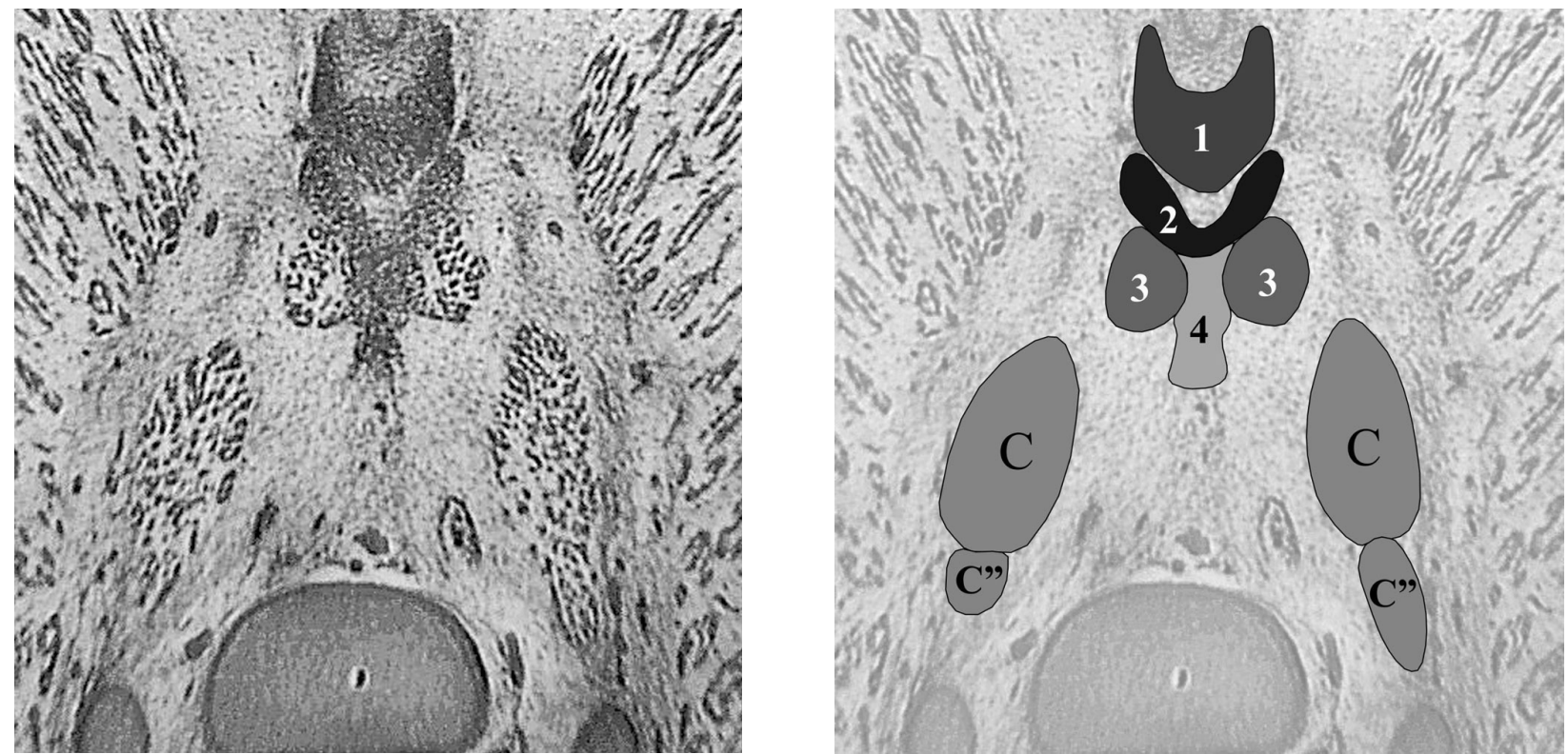

Figure 50mm.6

Photograph of a section just behind the rectum and in front of the os coccygis.

C, m. coccygeus; C", dorsal part of m. coccygeus (future ligamentum sacrospinale); 1, superficial part of $\mathrm{m}$. sphincter ani externus; $\mathbf{2}$, deep part of $\mathrm{m}$. sphincter ani externus; $\mathbf{3}, \mathrm{m}$. levator ani; $\mathbf{4}$, ligamentum anococcygeum. The left and right levator ani are attached to the deep part of the external sphincter and the ligamentum anococcygeum. They are not directly attached to each other. The m. coccygeus is divided in a ventral and dorsal part. 

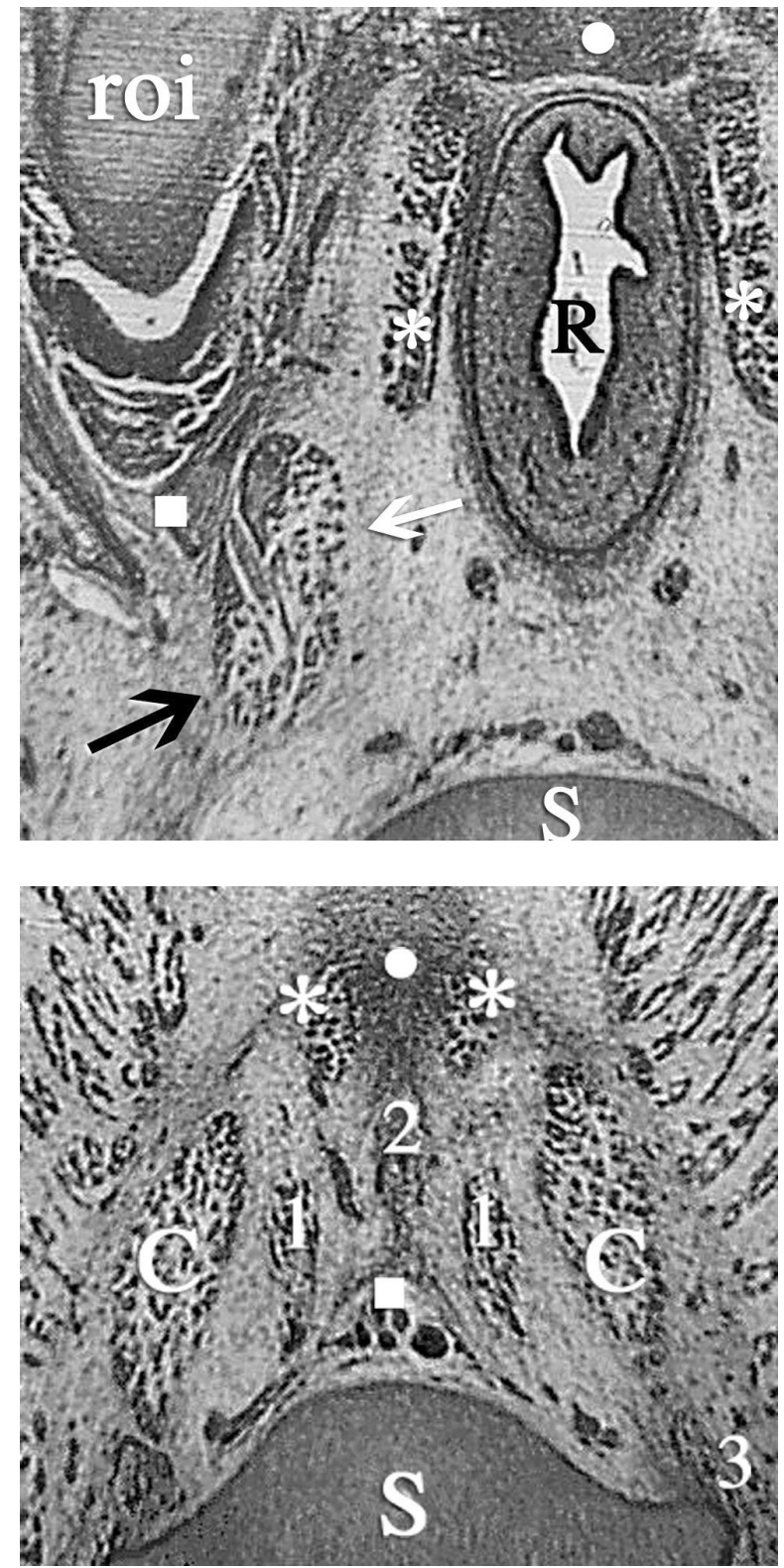

Figure 50mm.7: Close-up of Figure 50mm.4

$\mathbf{R}$, rectum; roi, ramus ossis ischii; $\mathbf{S}$, os sacrum; white dot, external anal sphincter; *, m. levator ani; white square, nervus pudendus; black arrow, ligamentum sacrospinale (dorsal part m. coccygeus); white arrow, m. coccygeus (ventral part).

The $\mathrm{m}$. coccygeus (here on the left side) is divided in a ventral and a dorsal part by a structure that appears to be a branch of the nervus pudendus. Following this division it becomes apparent that the dorsal part is the future ligamentum sacrospinale. This would explain the close relationship of the ligamentum sacrospinale and the $\mathrm{m}$. coccygeus in adult humans.

\subsubsection{D-reconstruction}

Oblique view from above on the pelvic diaphragm (Figure 50mm.10)

This picture of the reconstruction is taken from above, showing the (right) pelvic diaphragm from the inside of the pelvis. In the lower middle is the os sacrum. In the upper left corner the symphysis pubica.

The left and right corpus ossis pubis meet in the midline, forming the symphysis pubica (2).
Figure 50mm.8: Photograph of a section just in front of the tip of the os coccygis.

C, m. coccygeus; S, os sacrum; white dot, ligamentum anococcygeum; white square, a/v sacralis mediana; *, m. levator ani; $\mathbf{1}, \mathrm{m}$. sacrococcygeus ventralis; $\mathbf{2}$, ligamentum sacrococcygeum ventrale; $\mathbf{3}$, future ligamentum sacrospinale.

The ventral part of the $\mathrm{m}$. coccygeus runs further towards the os coccygis. The dorsal part (ligamentum sacrospinale) has just inserted onto the os sacrum. The left and right levator ani are attached to the ligamentum anococcygeum but not to each other. 
In dark blue the reconstruction of the $\mathrm{m}$. levator ani is shown. It covers the $\mathrm{m}$. obturatorius internus almost completely. The oblique border between the levator ani and the obturatorius internus is in fact the ATLA, running from the inner aspect of the ramus inferior ossis pubis to the later originating spina ischiadica. The ATLA is the very broad origin of the levator ani in contrast to the narrow insertion on the os coccygis. This reconstruction of the $\mathrm{m}$. levator ani also makes it distinctly clear that the levator ani consist of one single muscle that covers the frontal half of the pelvic outlet and has a somewhat triangular shape.

The $\mathrm{m}$. coccygeus is reconstructed in green. Its origin is at the level of the later formed spina ischiadica and its insertion is on the surface of the last sacral and first coccygeal vertebra. The $\mathrm{m}$. coccygeus has somewhat the same shape and volume as the m. levator ani and covers the dorsal half of the pelvic outlet.

The $\mathrm{m}$. levator ani and the $\mathrm{m}$. coccygeus are two separate muscles, distinguishable from each other by a small space between them, together closing the pelvic outlet.

The $\mathrm{m}$. sacrococcygeus ventralis is reconstructed as an example of a rudimentary muscle present in this fetus, shown in light blue. It does not cover any part of the actual pelvic outlet and is therefore not considered to belong to the pelvic diaphragm.

\subsubsection{D-reconstruction}

Frontal (Figure 50mm.11) and caudal

(Figure 50mm.12) views of the pelvic diaphragm

Figure $50 \mathrm{~mm} .11$ shows a complete frontal picture of the reconstruction. It immediately becomes clear that the pelvic outlet of this $50 \mathrm{~mm}$ fetus is projected in the frontal plain, thus pointing forwards. This is in striking contrast to the more backwards oriented pelvic outlet in adult humans. Formation of the angle at the level of the promon- torium and the disappearing of the ventral angle between os sacrum and os coccygis is responsible for this backward shifting of the pelvic outlet towards maturity. The sharp angle of the os coccygis to the os sacrum in this fetus is well visible in Figure 50mm.12

The m. obturatorius internus is reconstructed in red. It covers the foramen obturatum completely except for a small part, which forms the canalis obturatorius (Figure $50 \mathrm{~mm} .11$ ). The $\mathrm{m}$. obturatorius internus in this $50 \mathrm{~mm}$ fetus in fact resembles the adult situation.

Again in dark blue the $\mathrm{m}$. levator ani is shown. It runs from the os pubis (corpus ossis pubis, lower margin of the ramus inferior ossis pubis) to the os coccygis. The left and right $\mathrm{m}$. levator ani surround the corpus pelvinum, which is reconstructed in yellow.

The left and right levator ani are each separate muscles and are curved inwards and towards each other at a level between the sinus urogenitalis and the rectum and between the rectum and the os coccygis. The point between the sinus urogenitalis and the rectum will form the centrum tendineum as the developing left and right levator ani will eventually meet in the midline. Behind the rectum, in front of the os coccygis, the left and right levator ani will eventually end at the level of the developing ligamentum anococcygeum. Thus closure of the pelvic outlet in the midline by the two halves of the pelvic diaphragm will eventually take place at the level of the centrum tendineum and the ligamentum anococcygeum. However closure of the pelvic diaphragm in the midline is not yet present in this fetal stage. The insertion of the $\mathrm{m}$. levator ani onto the surface of the os coccygis is not yet completed. A small gap is still present, formed by connective tissue that is not reconstructed.

The $\mathrm{m}$. coccygeus, reconstructed in green, appears to be much thicker than the $\mathrm{m}$. levator ani. In this early fetal period the $\mathrm{m}$. coccygeus appears to have a much more dominant 
role in the formation of the pelvic diaphragm as it has in later adult life. The position of the $\mathrm{m}$. coccygeus is more lateral in relation to the $\mathrm{m}$. levator ani. The two muscles show what looks like a 'roof tile' formation
A close look at Figure $50 \mathrm{~mm} .12$ suggests that the pelvic diaphragm consists of four quadrants. The ventral left and ventral right quadrant are filled by the left and right $\mathrm{m}$. levator ani and the dorsal quadrants by the $\mathrm{m}$. coccygeus respectively [see also Marani, 2002].
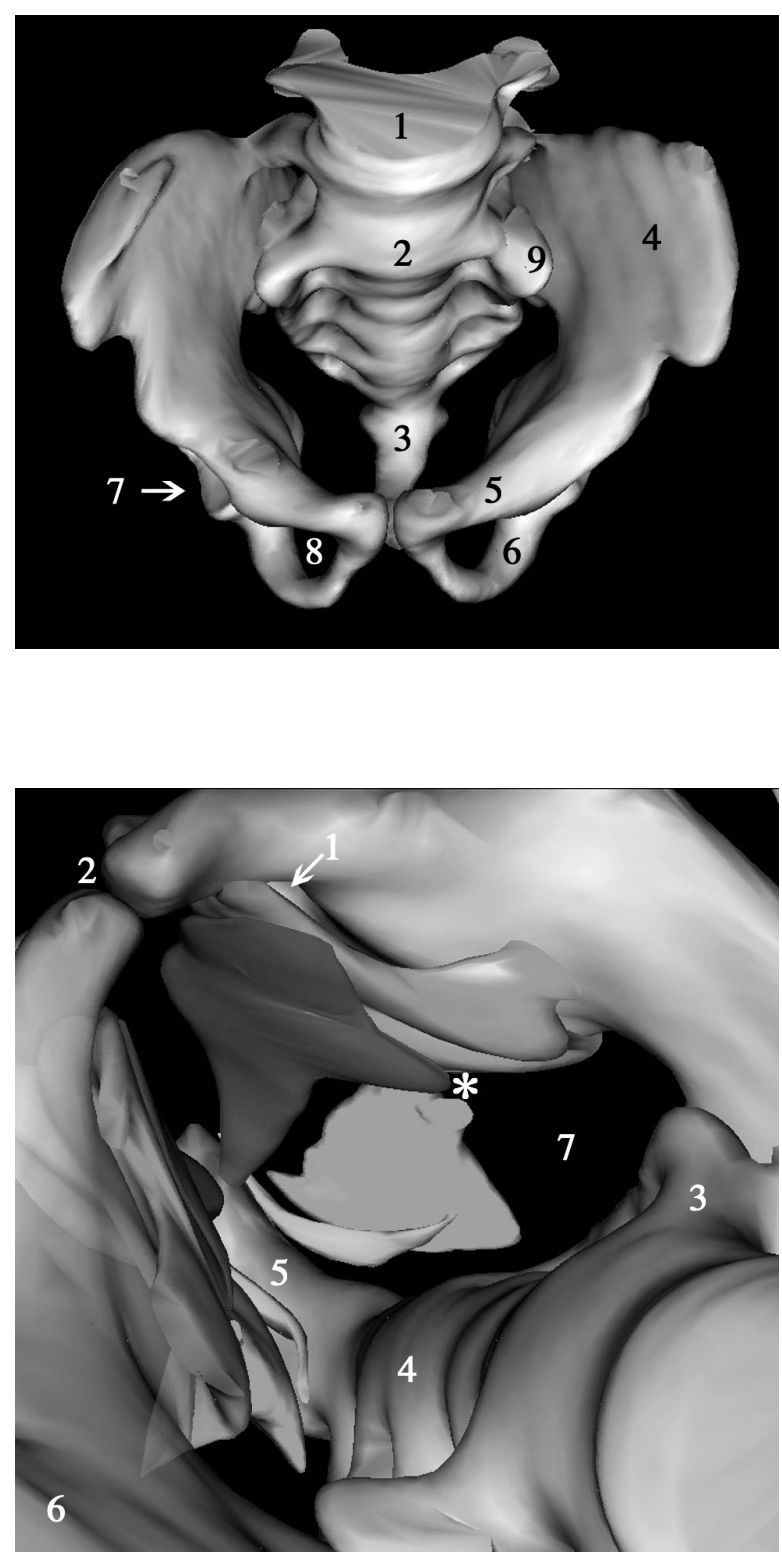

Figure 50mm.9: Overview of the fetal 'bony' pelvis

1, last lumbar vertebra; 2, first sacral vertebra; 3, os coccygis; 4, ala ossis ilii; $\mathbf{5}$, ramus superior ossis pubis; $\mathbf{6}$, ramus inferior ossis pubis; $\mathbf{7}$, acetabulum; 8 , foramen obturatum; $\mathbf{9}$, pars lateralis of os sacrum.

On the left and right side of the first sacral vertebra (2) the pars lateralis (9) is visible, together with 4 forming the sacroiliac joint.

Figure 50mm.10: View from above, on the pelvic diaphragm $\mathbf{1}$, canalis obturatorius; $\mathbf{2}$, symphysis pubica; $\mathbf{3}$, pars lateralis $; \mathbf{4}$, os sacrum; $\mathbf{5}$, os coccygis; $\mathbf{6}$, os ilium; $\mathbf{7}$, foramen ischiadicum majus; *, future spina ischiadica; red, $\mathrm{m}$. obturatorius internus; blue, $\mathrm{m}$. levator ani; green, m. coccygeus; light blue, m. sacrococcygeus ventralis.

For illustrative purposes the pelvic viscera (sinus urogenitalis and rectum) have been left out. The $\mathrm{m}$. levator ani closes the ventral half of the pelvic outlet. Ventral to dorsal it is completely covering the $\mathrm{m}$. obturatorius internus. The $\mathrm{m}$. coccygeus closes the dorsal half of the pelvic outlet and has the same size as the m. levator ani. 


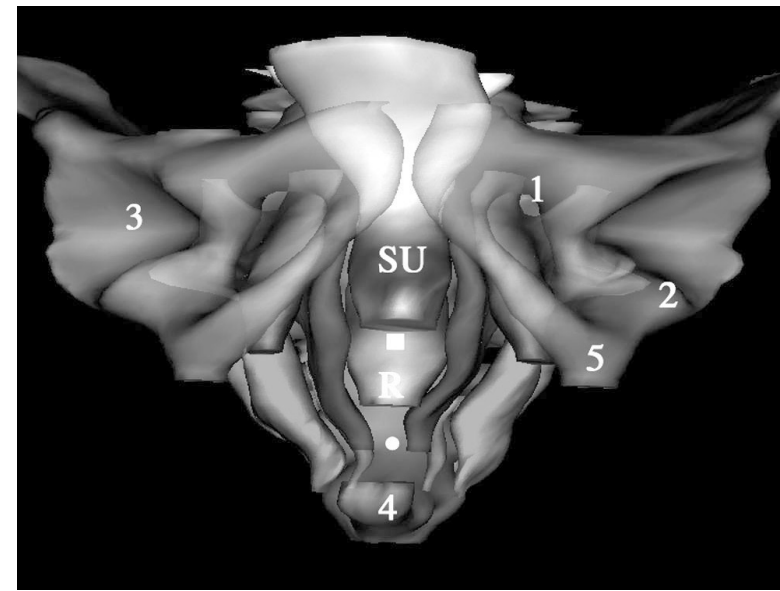

Figure 50mm.11: Frontal view of the pelvic diaphragm $\mathbf{1}$, canalis obturatorius; $\mathbf{2}, \mathrm{m}$. obturatorius internus leaving pelvis to insert on femur; $\mathbf{3}$, acetabulum; $\mathbf{4}$, os coccygis; $\mathbf{5}$, ramus ossis ischii; $\mathbf{S U}$, sinus urogenitalis; $\mathbf{R}$, rectum; red, m. obturatorius internus; blue, $\mathrm{m}$. levator ani; green, $\mathrm{m}$. coccygeus; light blue, $\mathrm{m}$. sacrococcygeus ventralis.

The $\mathrm{m}$. obturatorius internus completely covers the foramen obturatum except for the canalis obturatorius. Note the lateral position of the $\mathrm{m}$. coccygeus in regard to the $\mathrm{m}$. levator ani. The left and right $\mathrm{m}$. levator ani show curving around the sinus urogenitalis and rectum nearing each other at the level of the future centrum tendineum (white square) and ligamentum anococcygeum (white dot).

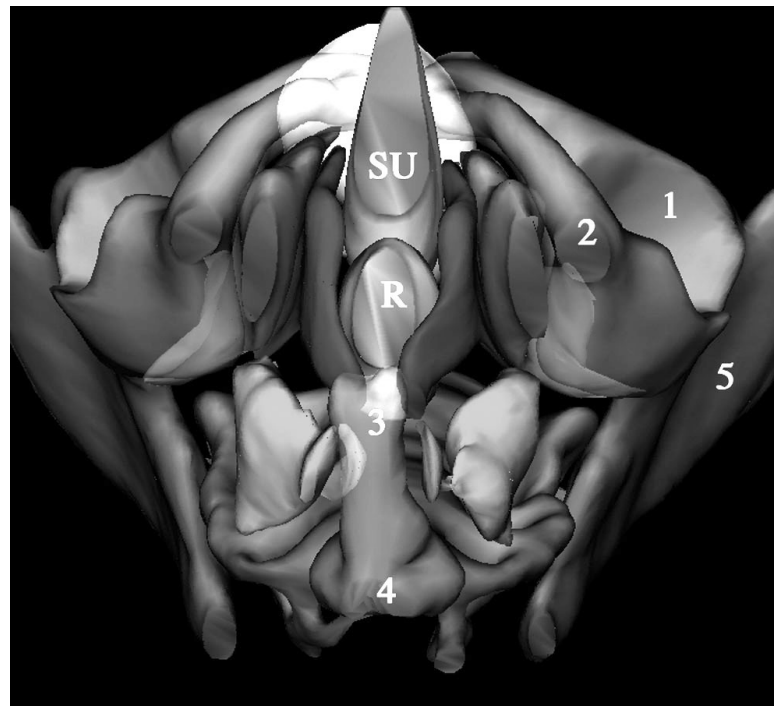

Figure 50mm.12: View of the pelvic diaphragm from below $\mathbf{1}$, acetabulum; $\mathbf{2}$, ramus ossis ischii; $\mathbf{3}$, os coccygis; $\mathbf{4}$, last sacral vertebra; $\mathbf{5}$, os ilium; $\mathbf{S U}$, sinus urogenitalis; $\mathbf{R}$, rectum; red, $\mathrm{m}$. obturatorius internus; blue, m. levator ani; green, m. coccygeus; light blue, $\mathrm{m}$. sacrococcygeus ventralis.

Note the 'four quadrant' formation of the pelvic diaphragm.

\section{$2.243 \mathrm{~mm}$ (WK 4409) and $42 \mathrm{~mm}$ (WK 3222), \pm 10 weeks}

\subsubsection{General features}

These fetuses with a CRL of $43 \mathrm{~mm}$ and $42 \mathrm{~mm}$ respectively are about 10 weeks post conception. They are cut transverse in $10 \mu \mathrm{m}$ sections and stained with HE (see Table 2).

From the appearance of the internal pelvic organs it is apparent that these fetuses are female as a uterus (fused paramesonephric ducts) and two ovaries can be clearly identified in the sections through the pelvic organs. Figure $43 \mathrm{~mm} .1$ gives an overview of one of the sections through the pelvic organs in the $43 \mathrm{~mm}$ fetus. The level of the section taken is just above the ramus superior ossis pubis. On the left side the m. psoas major and the $\mathrm{m}$. iliacus can be seen leaving the pelvic cavity. The urachus (future bladder) can be identified, as well as the uterus and the colon sigmoi- deum. Beside the colon sigmoideum the ureters are visible. The corpus pelvinum is embedded in connective tissue with mesenchyme and blood vessels. There seems to be less fat present than in the $50 \mathrm{~mm}$ fetus. The uterovesical and rectouterine pouch are visible. On both sides the external iliac vessels are prominently visible beside the corpus pelvinum.

The development of the bony pelvis is nearly complete. The separately developing bones are all outlined in cartilage and no ossification can be seen. At this stage the corpus ossis ilii, the corpus ossis ischii and the corpus ossis pubis can be identified individually. Yet in contrast to the $50 \mathrm{~mm}$ fetus, several dense centers of developing cartilage can be seen and the volume of the completed cartilage seems to be less than in the $50 \mathrm{~mm}$ fetus. This is especially striking at the level between the os ilium and the os ischii and at the level of the developing labrum glenoidale. 
A thick layer of tissue is surrounding the developing ala ossis ilii. This is developing cartilage (Figure $43 \mathrm{~mm} .1$ and Figure $43 \mathrm{~mm} .2$ ). The tuber ischiadicum and spina ischiadica of the os ischii are present as mesenchymal condensations and not as cartilaginous tissue. The crista iliaca superiorly, the tuberositas iliaca dorsally and the spina iliaca anterior superior ventrally have not yet developed.

The os sacrum of the fetuses is fully developed in cartilage; fusion of the vertebrae is not yet present. Connection of the os sacrum to the os coxae is formed through ligaments attaching the pars lateralis of the os sacrum to the os coxae. These ligg. sacroiliaca interossea can be identified as such. The os coccygis is formed in cartilage and shows fusion of the third tot fifth vertebra.

After reconstruction of the cartilaginous pelvis of the $43 \mathrm{~mm}$ fetus it becomes apparent, like the $50 \mathrm{~mm}$ fetus, that the typical angle at the level of the promontorium is not visible and that the os coccygis makes a sharp angle ventrally. Absence of the angle at the level of the promontorium and the sharp angle of the os coccygis causes the ventral position of the pelvic outlet present in this fetus.

\subsubsection{Musculus obturatorius internus}

At this stage the $m$. obturatorius internus itself does not completely cover the foramen obturatum. Especially at the level of the os pubis the developing muscle fibers do not reach the surface of the inner aspect of the corpus ossis pubis, i.e. the ramus superior and inferior ossis pubis. The fascia of the m. obturatorius internus however is attached to the corpus ossis pubis (Figure 43mm.3). Dorsally the $\mathrm{m}$. obturatorius internus reaches as far as it does in the $50 \mathrm{~mm}$ fetus. It reaches the most dorsal part of the corpus ossis ischii, and can be seen leaving the pelvis to insert onto the trochanter major femoris. Compared to the $50 \mathrm{~mm}$ fetus the $\mathrm{m}$. obturatorius internus is less developed on its ventral and cranial side.

At its lateral side the $\mathrm{m}$. obturatorius is covered by the membrana obturatoria. The membrana obturatoria however is thicker than in the $50 \mathrm{~mm}$ fetus. It appears to be less condensed at the age of 10 weeks in comparison to the age of 12 weeks. On the other side of the membrana obturatoria the $\mathrm{m}$. obturatorius externus can be identified (Figure 43mm.3).

The nervus obturatorius can be seen leaving the pelvis just below the ramus superior ossis pubis. The nerve, however, is not completely surrounded by the m. obturatorius internus. The muscle starts to appear just below the level of the nervus obturatorius, not present on the ventral and dorsal side of the nervus obturatorius. The canalis obturatorius as such has thus not completely developed.

Just below the level of the symphysis, on the inner aspect of the ramus inferior ossis pubis, a dense band of connective tissue can be seen. It runs towards the urachus and eventually radiating around it. This is the developing pubovesical ligament covered by the endopelvic fascia.

\subsubsection{Musculus levator ani}

On the medial aspect of the m. obturatorius internus, just below the nervus obturatorius, the $\mathrm{m}$. levator ani can be identified. It originates at the inner aspect of the ramus inferior ossis pubis separated by a small border of connective tissue. The muscle's origin is in between the $\mathrm{m}$. obturatorius internus and ligamentum pubovesicalis (ventral part of the arcus tendineus fascia pelvis) (Figure $43 \mathrm{~mm} .4$ ). A clear arcus tendineus levatoris ani (ATLA), as in the $50 \mathrm{~mm}$ fetus, cannot be identified. In stead a somewhat broader, less condensed strand of connective tissue is present near the origin of the $\mathrm{m}$. levator ani.

As the $\mathrm{m}$. levator ani originates it covers about half of the medial aspect of the m. obturatorius internus and is separated from it by a small band of connective tissue, formed by the individ- 
ual fascia of the two muscles. As it originates it is immediately clear that the $\mathrm{m}$. levatoris any is one muscle. In contrast to the $50 \mathrm{~mm}$ fetus, the $\mathrm{m}$. levator ani keeps a close relationship with the $\mathrm{m}$. obturatorius internus as it progresses towards the os coccygis. Behind the sinus urogenitalis it starts to separate, but keeps a close contact dorsally until the $\mathrm{m}$. obturatorius internus disappears as it inserts onto the ramus ossis ischii. The medial aspect of the $\mathrm{m}$. levator ani is separated from the corpus pelvinum by loose connective tissue.

Progressing caudally the thickness of the $\mathrm{m}$. levator ani starts to increase, especially on the ventral side. The ventral to dorsal length increases and at the lower level of the foramen obturatum the $\mathrm{m}$. levator ani has developed to a muscle almost completely covering the $\mathrm{m}$. obturatorius internus. The decreasing ventral-dorsal length of the $\mathrm{m}$. obturatorius internus also attributes to this partial covering. The covering of the $\mathrm{m}$. obturatorius internus at this stage is not as complete as it is in the $50 \mathrm{~mm}$ fetus. Especially on the dorsal side, near the corpus ossis ischii, the m. levator ani does not completely cover the $\mathrm{m}$. obturatorius internus. Complete covering starts to appear near the level of the ramus ossis ischii as the m. obturatorius internus starts to decrease as it inserts on the surface of the ramus ossis ischii. At this level a third muscle starts to appear. This is the $\mathrm{m}$. coccygeus that will be discussed later on. The levator ani is not directly attached to the dorsal end of the corpus ossis ischii. Attachment is made by connective tissue. This is the ATLA that is less developed near the ramus ossis ischii and the future spina ischiadica than it is in the $50 \mathrm{~mm}$ fetus.

On the ventral side, the distance between the ramus inferior ossis pubis and the $\mathrm{m}$. levator ani increases as it is passing alongside the sinus urogenitalis. The $\mathrm{m}$. levator ani is lying immediately adjacent to the sinus urogenitalis, but is not attached to it. On the most ventral side, the m. levator ani is attached to a thick layer of connective tissue extending towards the medial aspect of the sinus urogenitalis, the inner aspect of the ramus inferior ossis pubis and the ventral side of the $\mathrm{m}$. obturatorius internus. This is at the level of the urogenital diaphragm (Figure $43 \mathrm{~mm} .5$ ). Just behind the sinus urogenitalis the deep part of the $m$. sphincter ani externus appears in front of the $\mathrm{m}$. levator ani. The $\mathrm{m}$. levator ani has a very close relationship with this part of the $\mathrm{m}$. sphincter ani externus, but is not attached to it. In between the sinus urogenitalis and the rectum, a clear connection between the left and right $\mathrm{m}$. levator ani is not present. This is in contrast to the $50 \mathrm{~mm}$ fetus, where a developing centrum tendineum can be identified.

Passing around the rectum the $\mathrm{m}$. levator ani keeps a close relationship with the deeper part of the $\mathrm{m}$. sphincter ani externus, but remains unattached to it. The $\mathrm{m}$. levator ani is always separated from the rectum by a small layer of connective tissue. Behind the rectum the left and right $\mathrm{m}$. levator ani start to come towards the midline, following the dorsal part of the $\mathrm{m}$. sphincter ani. Midline attachment of the $\mathrm{m}$. sphincter ani to the left and right $\mathrm{m}$. levator ani is formed by a dense structure of connective tissue, running towards the os coccygis. This structure is the ligamentum anococcygeum. (Figure 43mm.6). The ligamentum anococcygeum is broader than it is in the 50 $\mathrm{mm}$ fetus. Therefore midline closure of the pelvis is less advanced.

\subsubsection{Musculus coccygeus}

At the surface of the most dorsal part of the corpus ossis ischii (the developing spina ischiadica), the $\mathrm{m}$. coccygeus originates. At this point the $\mathrm{m}$. levator ani inserts onto the developing spina ischiadica by a band of connective tissue. This is part of the arcus tendineus levatoris ani.

The $m$. coccygeus rapidly increase in volume as it progresses towards the os coccygis becoming bigger than the $\mathrm{m}$. levator ani. Just after its origin it becomes clear that the m. coccygeus consists of two parts: a ventral and a dorsal part. 
This is essentially the same as in the $50 \mathrm{~mm}$ fetus, although the separation is less defined. The dorsal part extends towards the lateral surface of the os sacrum, eventually inserting on its surface. This dorsal part of the $m$. coccygeus is the future ligamentum sacrospinale (Figure 43mm.6). The plexus ischiadicus can be seen running alongside the dorsal edge of the ligamentum sacrospinale.

The ventral part, or actual $\mathrm{m}$. coccygeus, travels towards the midline and continues towards the lateral aspect of the os coccygis. The $\mathrm{m}$. coccygeus is eventually lost in connective tissue before insertion on the surface of the os coccygis and os sacrum. The $m$. coccygeus can be traced further dorsally than the $\mathrm{m}$. levator ani and is always separated from the $\mathrm{m}$. levator ani by loose connective tissue. This border between the $\mathrm{m}$. coccygeus and levatoris ani appears to be broader than in the $50 \mathrm{~mm}$ fetus.

\subsubsection{Musculus sacrococcygeus ventralis}

The $\mathrm{m}$. sacrococcygeus ventralis is identified as a muscle lying medially from the $\mathrm{m}$. coccygeus (Figure $43 \mathrm{~mm} .6$ ). It originates from the pelvic surface of the os sacrum and inserts on the lateral aspect of the os coccygis. See the description of the $50 \mathrm{~mm}$ fetus for further details on the $\mathrm{m}$. sacrococcygeus.

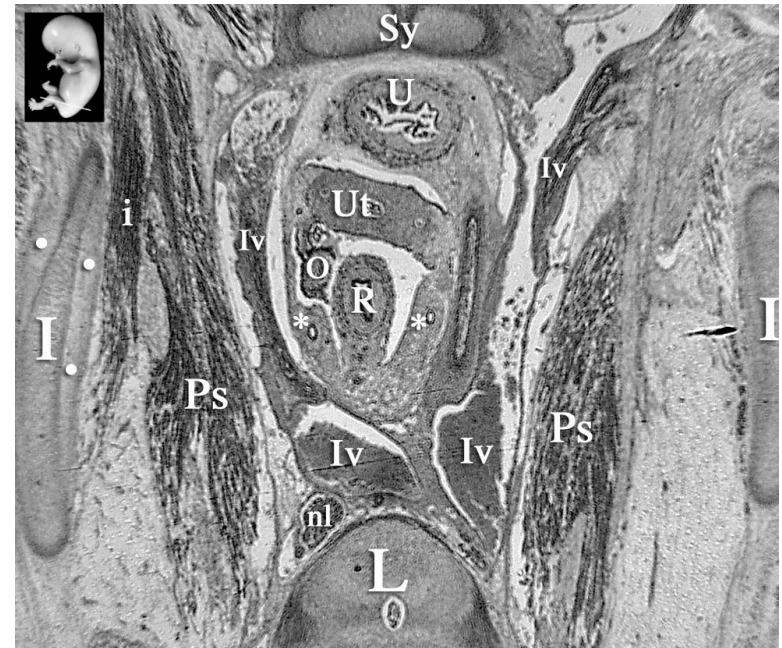

Figure 43mm.1

Insert: level of section indicated by white line.

$\mathbf{I}$, os ilium; i, m. iliacus; Iv, iliac vessel; $\mathbf{L}$, fifth lumbar vertebra; nl, lymph node; $\mathbf{O}$, ovary; Ps, m. psoas major; $\mathbf{R}$, sigmoid; $\mathbf{S y}$, symphysis pubica; $\mathbf{U}$, urachus (bladder); $\mathbf{U t}$, uterus (fused paramesonephric ducts centrally and two mesonephric ducts laterally; *, ureter; white dot, developing cartilage.

The left os ilium is surrounded by a thick layer of developing cartilage.

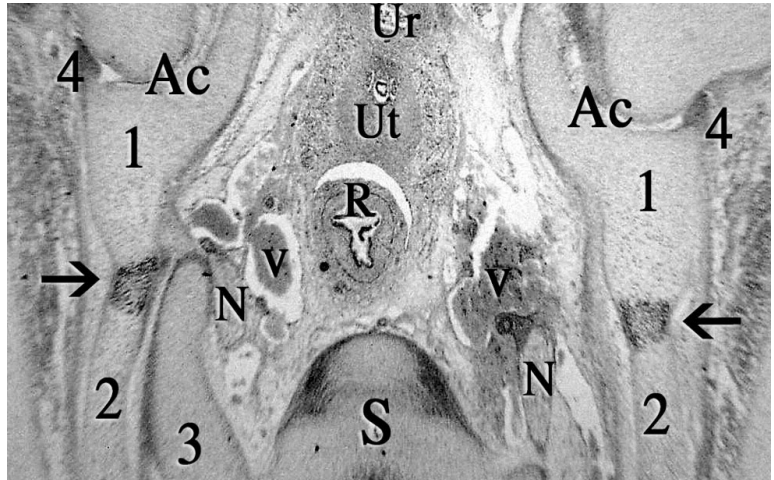

Figure 43mm.2

Ac, acetabulum; N, first sacral nerve; Ur, urachus; Ut; uterus; $\mathbf{R}$, rectum; $\mathbf{S}$, os sacrum (first vertebra); $\mathbf{V}$, iliac vein; black arrow, border between os ilium and ischii; $\mathbf{1}$, os ischii; $\mathbf{2}$, os ilium; $\mathbf{3}$ pars lateralis os sacrum; $\mathbf{4}$, labrum glenoidale.

Around the os ilium, at the level of the black arrow, the thick layer of developing cartilage is well identified. 

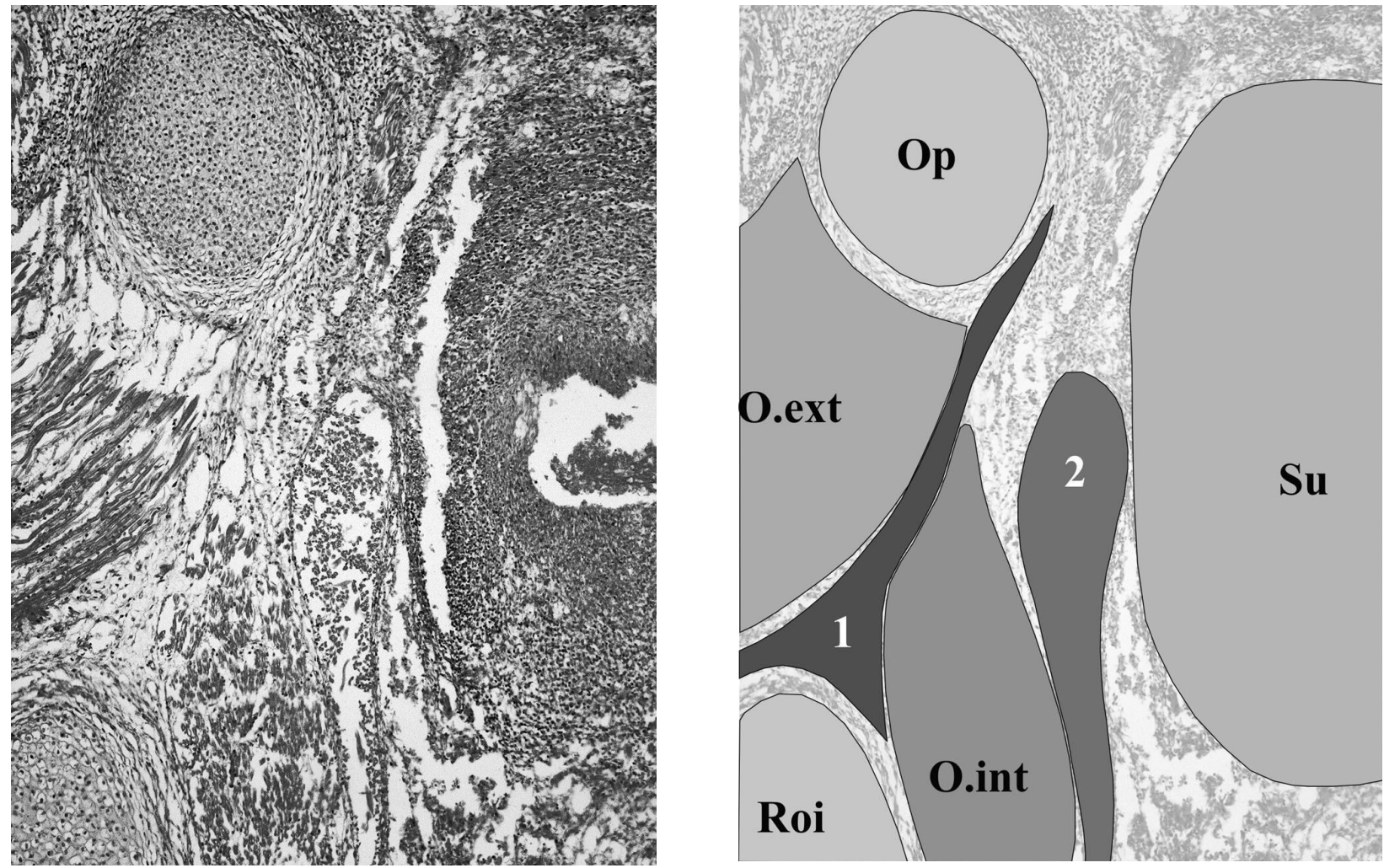

\section{Figure 43mm.3}

O.ext, m. obturatorius externus; O.int; m. obturatorius internus; Op, ramus inferior ossis pubis; Roi, ramus ossis ischii; Su, sinus urogenitalis; 2 , m. levator ani; $\mathbf{1}$, membrana obturatoria.

The m. obturatorius internus does not reach the os pubis, attachment is made by fascia. The membrana obturatoria is thicker than in the $50 \mathrm{~mm}$ fetus.

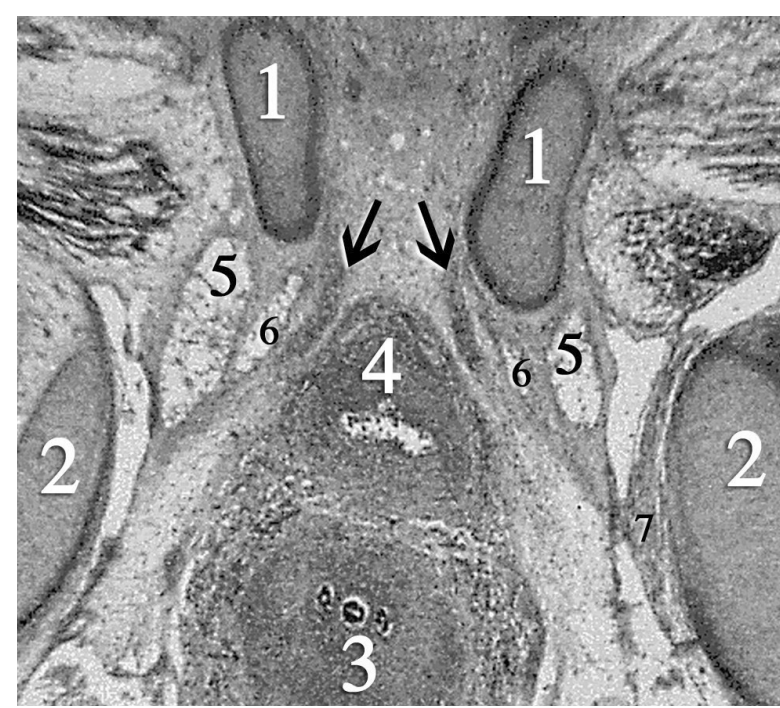

\section{Figure 43mm.4}

$\mathbf{1}$, ramus inferior ossis pubis; $\mathbf{2}$, ramus ossis ischii; $\mathbf{3}$, uterus; $\mathbf{4}$, bladder; $\mathbf{5}, \mathrm{m}$. obturatorius internus; $\mathbf{6}$, m. levator ani; $\mathbf{7}$, nervus obturatorius; black arrow, ligamentum pubovesicalis.

A dense band of connective tissue runs from the inner aspect of the os pubis alongside the bladder, partially overlying the $\mathrm{m}$. levator ani. This is the arcus tendineus fascia pelvis, i.e. the ligamentum pubovesicalis.

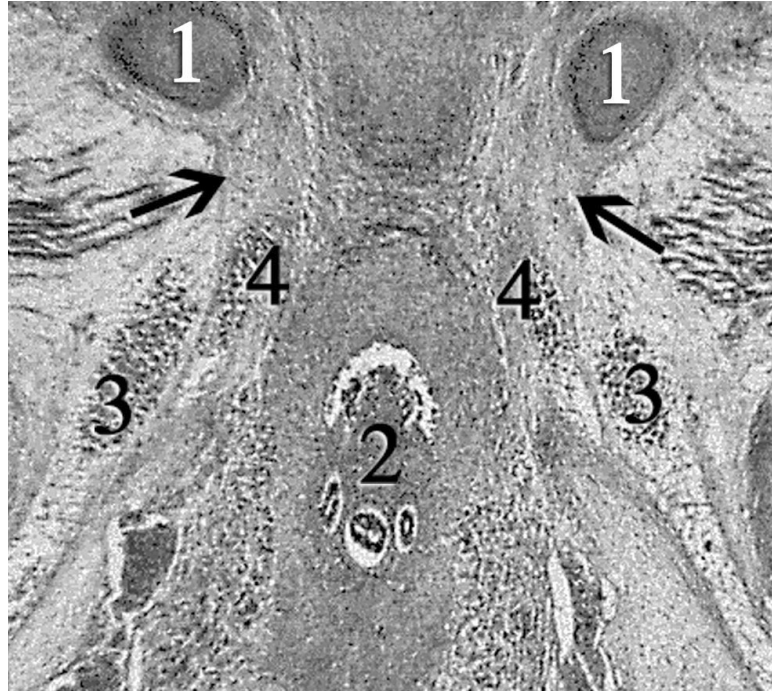

Figure 43mm.5

$\mathbf{1}$, ramus inferior ossis pubis; $\mathbf{2}$, sinus urogenitalis; $\mathbf{3}$, m. obturatorius internus; $\mathbf{4}, \mathrm{m}$. levator ani.

Black arrow: The m. obturatorius internus and levatoris ani are separated from the ramus inferior ossis pubis by a thick layer of connective tissue. 

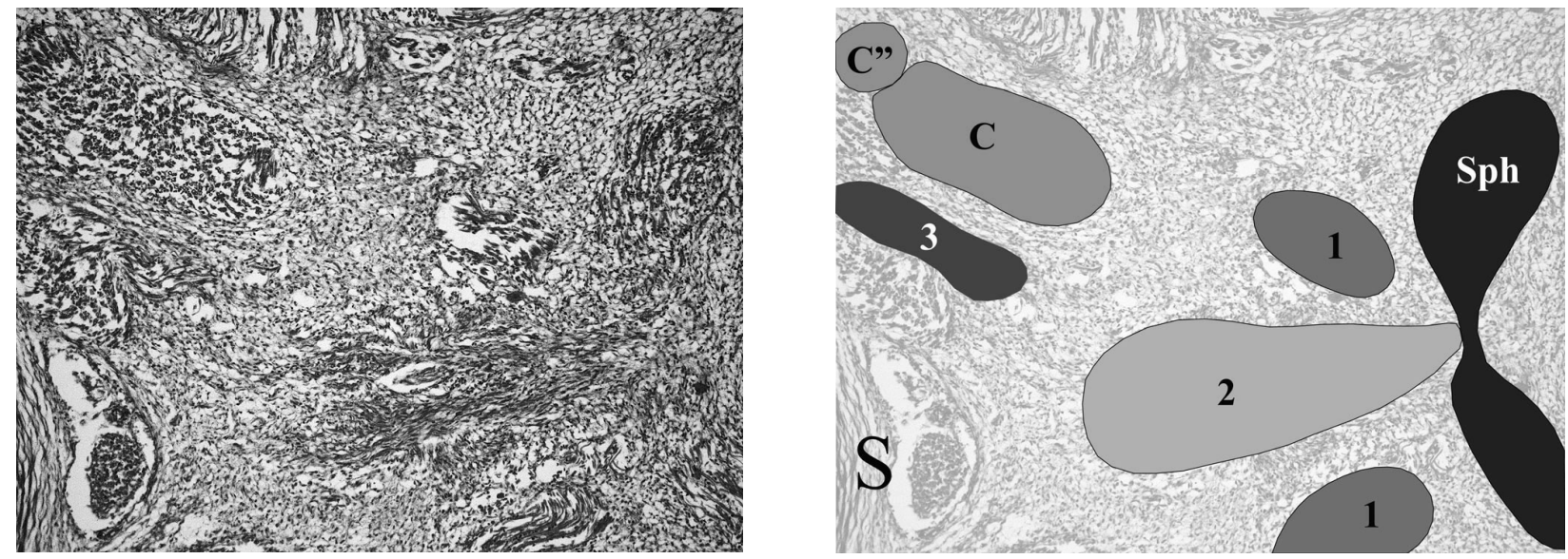

Figure 43mm.6

Section at the level of the ligamentum anococcygeum. On the left side the os sacrum (dorsal), on the right the external sphincter (ventral).

C", ligamentum sacrospinale; C, m. coccygeus; S, os sacrum; Sph, m. sphincter ani externus; 1, m. levator ani; 2, ligamentum anococcygeum; 3, m. sacrococcygeus ventralis.

Note that the $\mathrm{m}$. levator ani is not yet attached to the $\mathrm{m}$. sphincter ani externus.

\subsubsection{D-reconstruction}

Oblique view from above on the pelvic diaphragm (Figure 43mm.7)

This picture is taken from above, showing the (right) pelvic diaphragm from the inside of the pelvis. In the lower middle is the os sacrum. In the upper left corner the symphysis pubica.

The left and right corpus ossis pubis meet in the midline and are forming the symphysis pubica (2). The rectum and sinus urogenitalis, together forming the corpus pelvinum, have been left out.

In red the reconstruction of the m. obturatorius internus is shown. The ventral to dorsal extension from corpus ossis pubis to the corpus ossis ischii becomes visible. The dorsal extension of the m. obturatorius internus, however, is not as far as in the $50 \mathrm{~mm}$ fetus. Dorsally it does not completely cover the ramus and corpus ossis ischii. The m. obturatorius internus can also not be seen leaving the pelvis to insert on the head of the femur. On the ventral and cranial side the m. obturatorius does not completely reach the lower margin of the ramus superior ossis pubis, as it does in the $50 \mathrm{~mm}$ fetus. A completely developed canalis obturatorius is not yet present (1). When compar- ing the extension of the $\mathrm{m}$. obturatorius internus to the $50 \mathrm{~mm}$ fetus it is clear that especially the development in the cranioventral direction is less in the $43 \mathrm{~mm}$ fetus.

In dark blue the reconstruction of the $\mathrm{m}$. levator ani is shown. It covers the m. obturatorius internus almost completely, but the dorsal extension is less than in the $50 \mathrm{~mm}$ fetus. The $\mathrm{m}$. levator ani in this $43 \mathrm{~mm}$ fetus does not reach the level of the future spina ischiadica. The oblique border between the levator ani and the obturatorius internus is in fact the ATLA, running from the inner aspect of the ramus inferior ossis pubis to the later formed spina ischiadica. The $\mathrm{m}$. levator ani has not yet developed far enough dorsally to reach the spina ischiadica. The ATLA already reaches the region of the future spina ischiadica, as it can be distinguished in the available slides. This reconstruction of the $\mathrm{m}$. levator ani also makes it distinctly clear that the levator ani consist of one single muscle that covers the frontal half of the pelvic outlet and has a somewhat triangular shape.

The $\mathrm{m}$. coccygeus is reconstructed in green. Its origin is at the level of the later formed spina ischiadica and its insertion is on the surface of the last sacral and first coccygeal vertebra. The 
m. coccygeus covers the dorsal half of the pelvic outlet. When comparing the $\mathrm{m}$. coccygeus to the $50 \mathrm{~mm}$ fetus it is clear that the muscle is less developed in the $43 \mathrm{~mm}$ fetus. Its ventral to dorsal extension is less. The space between the $\mathrm{m}$. levator ani and the surface of the os sacrum is broader. The $\mathrm{m}$. levator ani and the $\mathrm{m}$. coccygeus are two separate muscles, distinguishable from each other by a space between them filled with loose connective tissue. Together they close the pelvic outlet.

The $\mathrm{m}$. sacrococcygeus ventralis is not reconstructed in this $43 \mathrm{~mm}$ fetus. It does not cover any part of the actual pelvic outlet and is therefore not considered to belong to the pelvic diaphragm. See the reconstruction of the $50 \mathrm{~mm}$ fetus for an example.

\subsubsection{D-reconstruction}

Frontal (Figure 43mm.8) and caudal (Figure 43mm.9) view of the pelvic diaphragm

Figure $43 \mathrm{~mm} .8$ shows a complete frontal picture of the reconstruction. It is clear that the pelvic outlet of this $43 \mathrm{~mm}$ fetus is also projected in the frontal plain, thus pointing forwards. This is in striking contrast to the more backwards oriented pelvic outlet in adult humans. Formation of the angle at the level of the promontorium and the disappearing of the ventral angle between os sacrum and os coccygis is responsible for this backward shifting of the pelvic outlet. The sharp angle of the os coccygis to the os sacrum in this fetus is well visible in Figure 43mm.9. The forward projection of the pelvic diaphragm in this $43 \mathrm{~mm}$ fetus is identical to the $50 \mathrm{~mm}$ fetus.

The $\mathrm{m}$. obturatorius internus is reconstructed in red. It covers the foramen obturatum except for a small part cranial. In Figure $43 \mathrm{~mm} .8$ it is well visible that the $\mathrm{m}$. obturatorius internus does not reach the lower margin of the ramus superior ossis pubis. A clearly defined canalis obturatorius in this $43 \mathrm{~mm}$ fetus is not present as it is in the $50 \mathrm{~mm}$ fetus.

Again in dark blue the $\mathrm{m}$. levator ani is shown. It runs from the corpus ossis pubis and lower margin of the ramus inferior ossis pubis to the os coccygis. The left and right $m$. levator ani surround the corpus pelvinum, which is reconstructed in yellow.

The left and right levator ani are each separate muscles and are curved inwards and towards each other at a level between the sinus urogenitalis and the rectum and between the rectum and the os coccygis. The point between the sinus urogenitalis and the rectum will later form the centrum tendineum as the developing left and right levator ani will eventually meet in the midline. The actual formation of a centrum tendineum can be seen in the $50 \mathrm{~mm}$ fetus but not in this $43 \mathrm{~mm}$ fetus. Behind the rectum, in front of the os coccygis, the left and right levator ani will eventually meet at the level of the developing ligamentum anococcygeum. The distance between the left and right $\mathrm{m}$. levator ani at this point is broader than in the $50 \mathrm{~mm}$ fetus. Thus closure of the pelvic outlet in the midline by the two halves of the pelvic diaphragm will eventually take place at the level of the centrum tendineum and the ligamentum anococcygeum. So closure of the pelvic diaphragm in the midline is not yet present in this fetal stage. Compared to the 50 $\mathrm{mm}$ fetus, closure of the pelvic diaphragm in the midline is less advanced in the $43 \mathrm{~mm}$ fetus. The insertion of the $\mathrm{m}$. levator ani onto the surface of the os coccygis is not yet completed. A small gap is still present, formed by connective tissue that is not reconstructed.

The $m$. coccygeus, reconstructed in green, appears to be just as thick as the m. levator ani. In the $50 \mathrm{~mm}$ fetus the $\mathrm{m}$. coccygeus is much thicker. The position of the $\mathrm{m}$. coccygeus is more lateral in relation to the $\mathrm{m}$. levator ani. The two muscles show what looks like a 'roof tile' formation. This is the same as in the $50 \mathrm{~mm}$ fetus.

A close look at Figure $43 \mathrm{~mm} .9$ suggests that the pelvic diaphragm consists of four quadrants [Marani 2002], as it does in the $50 \mathrm{~mm}$ fetus. The ventral left and ventral right quadrants are filled by the left and right $\mathrm{m}$. levator ani and the dorsal quadrants by the m. coccygeus respectively. Only, compared to the $50 \mathrm{~mm}$ fetus, the covering of the dorsal quadrants by the $\mathrm{m}$. coccygeus is significantly less. 
full color illustrations of the photos on this page can be found on page 116-117
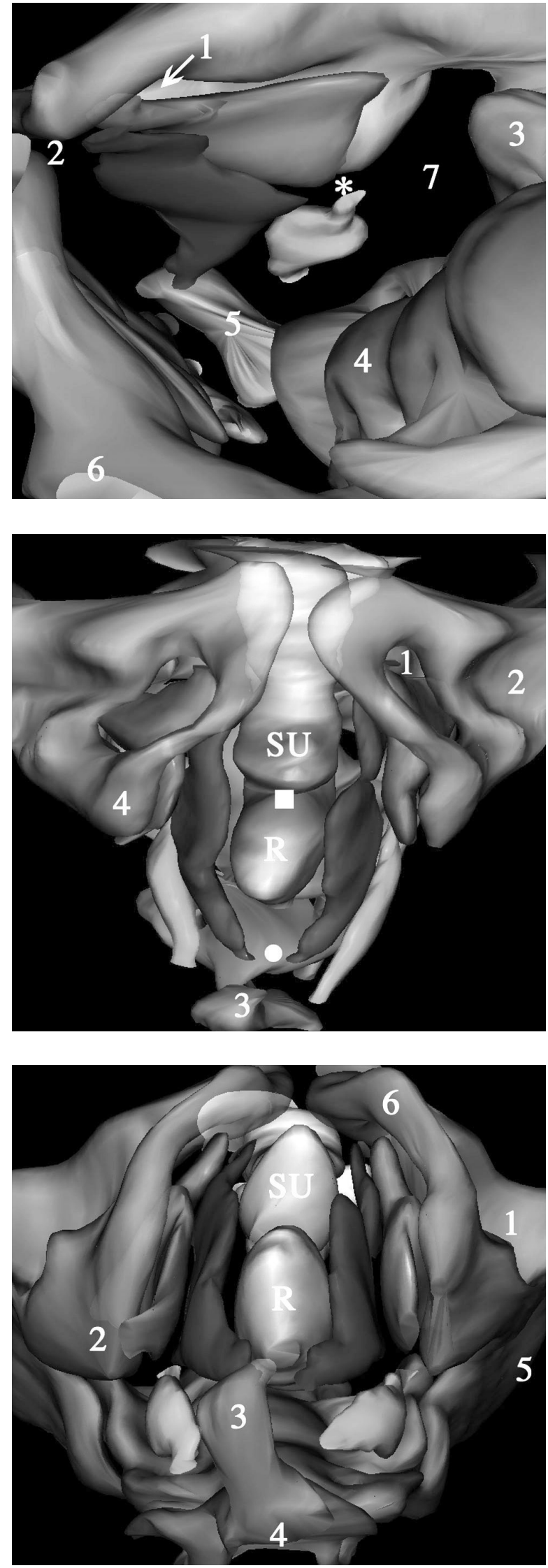

Figure 43mm.7

View from above, on the pelvic diaphragm.

$\mathbf{1}$, canalis obturatorius; $\mathbf{2}$, symphysis pubica; $\mathbf{3}$, articulatio sacroiliaca; $\mathbf{4}$, os sacrum; $\mathbf{5}$, os coccygis; $\mathbf{6}$, os ilium; $\mathbf{7}$, foramen ischiadicum majus; *, future spina ischiadica; red, m. obturatorius internus; blue, m. levator ani; green, m. coccygeus.

For illustrative purposes the pelvic viscera (sinus urogenitalis and rectum) have been left out. The $\mathrm{m}$. levator ani closes the ventral half of the pelvic outlet and is almost completely covering the m. obturatorius internus. Comparing to the $50 \mathrm{~mm}$ fetus the $\mathrm{m}$. levator ani does not extent as far dorsally. The $\mathrm{m}$. coccygeus closes the dorsal half of the pelvic outlet.

\section{Figure 43mm.8}

Frontal view of the pelvic diaphragm.

$\mathbf{R}$, rectum; SU, sinus urogenitalis; $\mathbf{1}$, canalis obturatorius; 2 , acetabulum; 3, os coccygis; $\mathbf{4}$, ramus ossis ischii; white square, future centrum tendineum; white dot, future ligamentum anococcygeum; red, m. obturatorius internus; blue, m. levator ani; green, $\mathrm{m}$. coccygeus.

The $\mathrm{m}$. obturatorius internus does not completely cover the foramen obturatum. It is not present near the canalis obturatorius. The left and right $\mathrm{mm}$. levatores ani show curving around the sinus urogenitalis and rectum at the level of the future centrum tendineum and ligamentum anococcygeum. Extension towards the midline is not as advanced as in the $50 \mathrm{~mm}$ fetus.

Figure 43mm.9

View of the pelvic diaphragm from below.

$\mathbf{R}$, rectum; SU, sinus urogenitalis; $\mathbf{1}$, acetabulum; $\mathbf{2}$, ramus ossis ischii / tuber ischiadicum; $\mathbf{3}$, os coccygis; $\mathbf{4}$, last sacral vertebra; $\mathbf{5}$, os ilium; $\mathbf{6}$, ramus inferior ossis pubis; red, m. obturatorius internus; blue, $\mathrm{m}$. levator ani; green, $\mathrm{m}$. coccygeus.

Note the 'four quadrant' formation of the pelvic diaphragm. The $\mathrm{m}$. coccygeus is less developed than in the $50 \mathrm{~mm}$ fetus. 


\section{$2.3 \quad 34 \mathrm{~mm}$ (WK 1438) and $35 \mathrm{~mm}$ (WK $7608), \pm 9$ weeks}

\subsubsection{General features}

These fetuses with a CRL of $34 \mathrm{~mm}$ and $35 \mathrm{~mm}$ respectively are about 9 weeks post conception. They are cut transverse in $10 \mu \mathrm{m}$ sections and stained with HE (see Table 2).

From the appearance of the internal pelvic organs it is apparent that both these fetuses are female. A developing uterus (fusion of paramesonephric ducts and developing cervix) and two developing ovaries can be clearly identified in the sections through the pelvic organs. Figure $34 \mathrm{~mm} .1$ shows an example of one of the sections through the pelvic organs in the $34 \mathrm{~mm}$ fetus. The section taken is just above the ramus superior ossis pubis and medio-lateral oblique. Due to this oblique orientation the right side of the section is just above the ramus superior ossis pubis. The left side of the section is at the level of the acetabulum. On the right side the vena iliaca externa continuing in the vena femoralis can be seen as the vena femoralis is passing over the ramus superior ossis pubis. Lateral to these vessels lays the $\mathrm{m}$. psoas major and the nervus femoralis dorsal of it. The allantois (future bladder) can be identified, as well as the uterus and the colon sigmoideum, forming part of the corpus pelvinum. On the right side, passing the future uterus, the right ureter can be identified. The corpus pelvinum is embedded in connective tissue with mesenchyme and blood vessels. The density of the connective tissue appears to be less than in the $43 \mathrm{~mm}$ fetus. There also seems to be less fat present than in the $43 \mathrm{~mm}$ fetus. The uterovesical and rectouterine pouch are visible.

The development of the bony pelvis is nearly complete. The separately developing bones are all outlined in cartilage and no ossification can be noted. At this stage the corpus ossis ilii, the corpus ossis ischii and the corpus ossis pubis can be identified individually. The borders between the separate bones are more defined than in the $43 \mathrm{~mm}$ fetus. Comparable to the 43 $\mathrm{mm}$ fetus, several centers of developing cartilage can be seen and the volume of the completed cartilage seems to be less than in the $50 \mathrm{~mm}$ fetus. This is especially striking at the level between the os ilium and the os ischii and at the level of the developing labrum glenoidale. A thick layer of tissue is surrounding the developing ala ossis ilii and corpus ossis ilii, building up the yet thin os ilium. The tuber ischiadicum and spina ischiadica of the os ischii are present as mesenchymal condensations and not as cartilaginous tissue. The ala ossis ilii shows a cartilaginous development centrally. The crista iliaca superiorly, the tuberositas iliaca dorsally and the spina iliaca anterior superior ventrally can not be distinguished.

The os sacrum of the fetuses is fully developed in cartilage. Fusion of the vertebrae is not yet present. Connection of the os sacrum to the os coxae is formed through ligaments attaching the pars lateralis of the os sacrum to the os coxae. These ligg. sacroiliaca interossea can be identified as such but seem to be far less developed than in the $43 \mathrm{~mm}$ and $50 \mathrm{~mm}$ fetuses. The os coccygis is formed in cartilage and shows fusion of the third tot fifth vertebra.

After evaluating the reconstruction of the cartilaginous pelvis of the $34 \mathrm{~mm}$ fetus it is apparent, like the $50 \mathrm{~mm}$ and $43 \mathrm{~mm}$ fetuses, that the typical angle at the level of the promontorium is not visible and that the os coccygis makes a sharp angle ventrally. Absence of the angle at the level of the promontorium and the sharp angle of the os coccygis seems responsible for the ventral position of the pelvic outlet present in this fetus. This is in accordance with the older fetuses.

\subsubsection{Musculus obturatorius internus}

At this stage the $\mathrm{m}$. obturatorius internus itself does not completely cover the foramen obturatum. Especially at the level of the os pubis the muscle fibers do not reach the surface of the inner 
aspect of the corpus ossis pubis, i.e. the ramus superior and inferior ossis pubis. The fascia of the $\mathrm{m}$. obturatorius internus however is attached to the corpus ossis pubis. On the dorsal side the $m$. obturatorius internus reaches the most dorsal part of the ramus ossis ischii only at a level just above the developing tuber ischiadicum. The muscle itself cannot be seen leaving the pelvic cavity as it does in the $50 \mathrm{~mm}$ fetus, where it can be seen to insert on the femur. In fact, at this $34 / 35 \mathrm{~mm}$ stage, only the fascia of the $\mathrm{m}$. obturatorius internus extends to the trochanter major femoris where it inserts.

At its lateral side the $\mathrm{m}$. obturatorius is covered by the membrana obturatoria. The membrana obturatoria is about as thick as in the 43 $\mathrm{mm}$ fetus but thicker than in the $50 \mathrm{~mm}$ fetus. On the other side of the membrana obturatoria the $\mathrm{m}$. obturatorius externus can be identified (Figure 34mm.2).

Following the sections, the nervus obturatorius can be seen leaving the pelvis just below the ramus superior ossis pubis. The nerve, however, is not completely surrounded by the $\mathrm{m}$. obturatorius internus. The muscle starts to appear well below the level of the nervus obturatorius and is not present on the ventral and dorsal side of the nervus obturatorius. The cranial extension of the $\mathrm{m}$. obturatorius internus is less than in the $43 \mathrm{~mm}$ fetus. This means that the foramen obturatum is not covered by the $\mathrm{m}$. obturatorius internus on the cranial side. The canalis obturatorius as such is not yet constituted.

Just below the level of the symphysis, on the inner aspect of the ramus inferior ossis pubis, a broad band of connective tissue can be seen. It runs towards the sinus urogenitalis and eventually radiating around it. This is the developing pubovesical ligament (considered as the ventral part of the ATLA in adult human anatomy) and the endopelvic fascia. Compared to the later stages, the ligament and fascia are less condensed. This is considered as a lesser development of the liga- ment and the endopelvic fascia in the $34 \mathrm{~mm}$ fetus than in the $43 \mathrm{~mm}$ and $50 \mathrm{~mm}$ fetuses.

In between the developing endopelvic fascia and the $\mathrm{m}$. obturatorius internus a thin and dense band of connective tissue appears. It appears at a level that is about halfway the foramen obturatum and well below the nervus obturatorius. This band of connective tissue is the arcus tendineus levatoris ani (or arcus tendineus fascia pelvis). The ATLA could be identified in the $43 \mathrm{~mm}$ fetus as a broad band of connective tissue. Compared to the $50 \mathrm{~mm}$ fetus the ATLA is less developed. It does not reach the inner aspect of the ramus inferior ossis pubis ventrally. Dorsally it does not extend as far as in the $50 \mathrm{~mm}$ fetus. When it arises it covers about a quarter of the medial aspect of the $\mathrm{m}$. obturatorius. It fades away in loose connective tissue that is extending to about halfway the $\mathrm{m}$. obturatorius internus (Figure 34mm.2).

\subsubsection{Musculus levator ani}

Following the ATLA through the fetus it starts to show a gradual thickening on the ventral side as muscle fibers start to appear. The muscle fibers are in a straight angle to the ATLA. When it originates the $\mathrm{m}$. levator ani does not show such a close relationship with the inner aspect of the ramus inferior ossis pubis as it does in the $50 \mathrm{~mm}$ fetus. Its ventral margin of muscle fibers is further away from the os pubis. The gap is filled by undefined connective tissue that will probably play a role in the development of the diaphragma urogenitalis. At its origin the dorsal extension of the $\mathrm{m}$. levator ani is over about a quarter of the medial aspect of the $\mathrm{m}$. obturatorius internus. In the 50 $\mathrm{mm}$ fetus it immediately covered more than half the medial aspect and in the $43 \mathrm{~mm}$ fetus about half.

The moment it originates it is again clear that the $\mathrm{m}$. levator ani is one single muscle. It stays separated from the $\mathrm{m}$. obturatorius internus by a small margin. As in the $43 \mathrm{~mm}$ fetus this close relationship is maintained all the way to the ramus 
ossis ischii at the point where the m. obturatorius internus leaves the pelvis.

Progressing caudally the thickness of the $\mathrm{m}$. levator ani starts to increase, especially on its ventral side. The ventral to dorsal length increases and at the upper level of the ramus ossis ischii the $\mathrm{m}$. levator ani has developed to a muscle covering the $\mathrm{m}$. obturatorius internus for about half. The $\mathrm{m}$. levator ani is at this point not yet fixed to the dorsal end of the corpus ossis ischii. The decreasing ventral-dorsal length of the $\mathrm{m}$. obturatorius internus mostly attributes to this partial covering. The covering of the $\mathrm{m}$. obturatorius internus at this stage is not as complete as it is in the $43 \mathrm{~mm}$ fetus. Especially on the dorsal side, near the corpus ossis ischii, the $\mathrm{m}$. levator ani does not completely cover the $\mathrm{m}$. obturatorius internus. Complete covering starts to appear near the level of the developing tuber ischiadicum where the $\mathrm{m}$. levator ani attaches to the surface of the developing spina ischiadica. At this level the $\mathrm{m}$. obturatorius internus completely disappears. At the point where the $\mathrm{m}$. levator ani attaches to the developing spina ischiadica a third muscle originates. This is the m. coccygeus.

Passing around the sinus urogenitalis the ventral side of the $\mathrm{m}$. levator ani is attached to connective tissue that appears to be the developing diaphragma urogenitalis. The $\mathrm{m}$. levator ani is nowhere directly attached to the sinus urogenitalis only lying closely adjacent to it. Behind the sinus urogenitalis no connection can be identified between the left and right $\mathrm{m}$. levator ani. They are separated from each other by connective tissue that does not have the appearance of a centrum tendineum like it has in the $50 \mathrm{~mm}$ fetus. In between the sinus urogenitalis and the rectum the m. sphincter ani externus starts to appear. The $\mathrm{m}$. levator ani is not attached to the m. sphincter ani externus, nor is it attached to the rectum (Figure $34 \mathrm{~mm} .3$ ). Behind the rectum the left and right $\mathrm{m}$. levator ani start to run towards the midline. Eventually the left and right $\mathrm{m}$. levator ani are connected to each other and to the most dorsal part of the m. sphincter ani internus by connective tissue. This connective tissue can be followed from the deep part of the $m$. sphincter ani externus to the tip of the os coccygis. It is the developing ligamentum anococcygeum (Figure $34 \mathrm{~mm} .4$ ), that shows about the same grade of development as it does in the $43 \mathrm{~mm}$ fetus.

Compared to the $43 \mathrm{~mm}$ fetus, the $\mathrm{m}$. levator ani in this $34 \mathrm{~mm}$ fetus shows the same position in relation to the corpus pelvinum. But the $\mathrm{m}$. levator ani in the $34 \mathrm{~mm}$ fetus does not extend as much dorsally as it does in the $43 \mathrm{~mm}$ and 50 mm fetus.

\subsubsection{Musculus coccygeus}

At the surface of the most dorsal part of the corpus ossis ischii, i.e. the future spina ischiadica, the $\mathrm{m}$. coccygeus originates (Figure $34 \mathrm{~mm} .3$ ). The $\mathrm{m}$. levator ani also attaches to the surface of the os ischii at this point. Attachment is made by connective tissue that is the arcus tendineus levatoris ani. In contrast to the $43 \mathrm{~mm}$ fetus the ATLA as such cannot be identified at the level of the os ischii and developing spina ischiadica.

After its origin the $m$. coccygeus increases in volume as it progresses towards the os coccygis but slower when compared to the 43 $\mathrm{mm}$ fetus. Like in the later stages the $\mathrm{m}$. coccygeus soon appears to consist of two parts (Figure $34 \mathrm{~mm} .3)$. In this $34 \mathrm{~mm}$ fetus a branch of the nervus pudendus can be seen passing in between the ventral and dorsal part. The dorsal part, that seems to be relatively bigger in this fetus when compared to the older fetuses, spreads out towards the surface of the os sacrum. This dorsal part is the future ligamentum sacrospinale.

The ventral part, or actual m. coccygeus, travels towards the midline. It can be followed up to its insertion on the lateral aspect of the last coccygeal vertebrae (Figure $34 \mathrm{~mm} .5$ ). Its relationship with the ligamentum anococcygeum is not clear. 
The $m$. coccygeus has no relationship or contact with the $\mathrm{m}$. levator ani. The $\mathrm{m}$. coccygeus runs dorsal and lateral from the $\mathrm{m}$. levator ani and is separated by a border of loose connective tissue. This border appears to be broader than in the $43 \mathrm{~mm}$ fetus. The $\mathrm{m}$. coccygeus can also be followed further towards the os coccygis than the $\mathrm{m}$. levator ani. The levator ani inserts on to the os coccygis via the ligamentum anococcygeum.

\subsubsection{Musculus sacrococcygeus ventralis}

The $\mathrm{m}$. sacrococcygeus ventralis is identified as a muscle lying medially from the $\mathrm{m}$. coccygeus (Figure $34 \mathrm{~mm} .6$ ). It originates from the pelvic surface of the os sacrum and inserts on the lateral aspect of the os coccygis. One should look into the description of the $50 \mathrm{~mm}$ fetus for further details on the $\mathrm{m}$. sacrococcygeus.
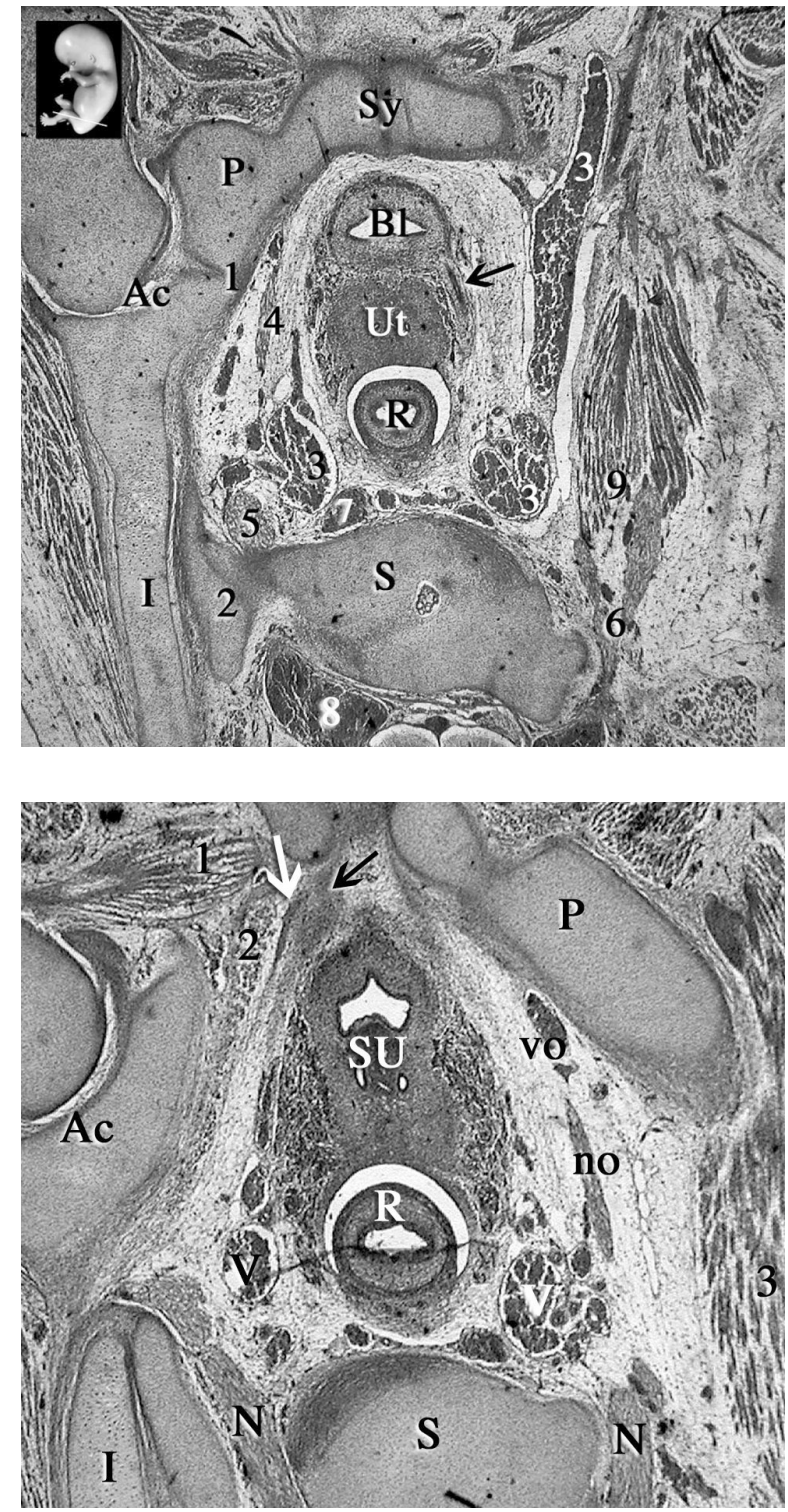

\section{Figure 34mm.1}

Insert: level of section indicated by a white line.

Ac, acetabulum; Bl, allantois (bladder); I, os ilium; P, os pubis; R, rectum/colon sigmoideum; $\mathbf{S}$, os sacrum; $\mathbf{S y}$, symphysis pubica; $\mathbf{U t}$ uterus (cervix); 1, separation os ischium/ pubis; 2, pars lateralis os sacrum; 3, a.v. iliaca externa/femoralis; $\mathbf{4}$, nervus obturatorius; $\mathbf{5}$, truncus lumbalis; $\mathbf{6}$, nervus femoralis; $\mathbf{7}$, presacral lymph node; $\mathbf{8}$, spinal cord root; $\mathbf{9}, \mathrm{m}$. psoas major; black arrow, right ureter.

Like in the $43 \mathrm{~mm}$ fetus the os ilium is surrounded by a thick layer of tissue as a sign of developing cartilage.

\section{Figure 34mm.2}

Ac, acetabulum; I, os ilium; $\mathbf{P}$, ramus superior ossis pubis; $\mathbf{N}$, nervus sacralis I; no, nervus obturatorius; $\mathbf{R}$, rectum; $\mathbf{S}$, os sacrum; SU, sinus urogenitalis; $\mathbf{V}$, vena iliaca interna; vo, vena obturatoria; 1, m. obturatorius externus; $\mathbf{2}, \mathrm{m}$. obturatorius internus; $\mathbf{3}, \mathrm{m}$. psoas major; white arrow, arcus tendineus levatoris ani; black arrow, endopelvic fascia. 

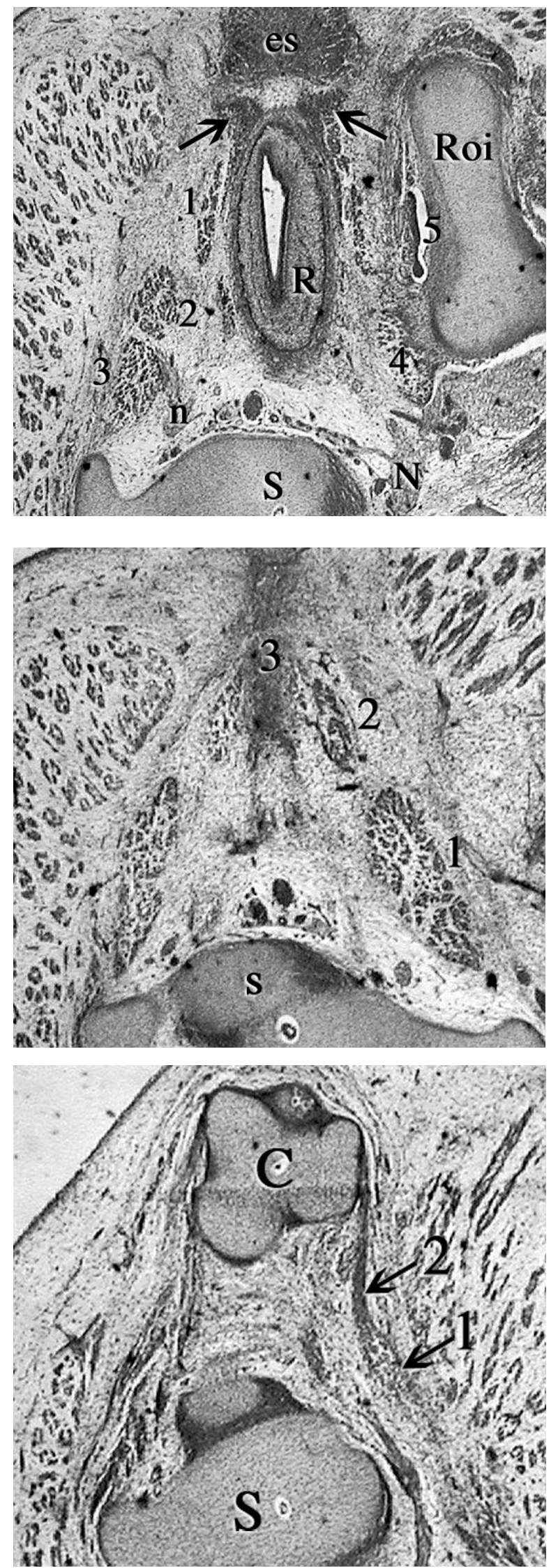

\section{Figure 34mm.3}

es, $\mathrm{m}$. sphincter ani externus; $\mathbf{N}$, nervus pudendus; $\mathbf{n}$, branch of $\mathbf{n}$. pudendus; R, rectum; Roi, ramus ossis ischii; $\mathbf{S}$, os sacrum; black arrow, $\mathrm{m}$. sphincter ani externus (deep part); 1, m. levator ani; 2 , ventral part $\mathrm{m}$. coccygeus; $\mathbf{3}$, dorsal part $\mathrm{m}$. coccygeus (ligamentum sacrospinale); $\mathbf{4}$, origin $\mathrm{m}$. coccygeus at developing spina ischiadica. The deep part of the $\mathrm{m}$. sphincter ani externus extends around the rectum, attaching to the $\mathrm{m}$. levator ani.

A branch of the nervus pudendus can be seen piercing between the ventral and dorsal part of the m. coccygeus.

Figure 34mm.4

S, os sacrum; $\mathbf{1}$, m. coccygeus; $\mathbf{2}$, m. levator ani; $\mathbf{3}$, ligamentum anococcygeum.

The $\mathrm{m}$. levator ani on the left side is fixed to the anococcygeal ligament. This ligament runs between the $\mathrm{m}$. sphincter ani externus and os coccygeus.

\section{Figure 34mm.5}

$\mathbf{C}$, os coccygis; $\mathbf{S}$, os sacrum; $\mathbf{1}, \mathrm{m}$. coccygeus; $\mathbf{2}$, fascia of the $\mathrm{m}$. coccygeus inserting on lateral aspect of os coccygis. 


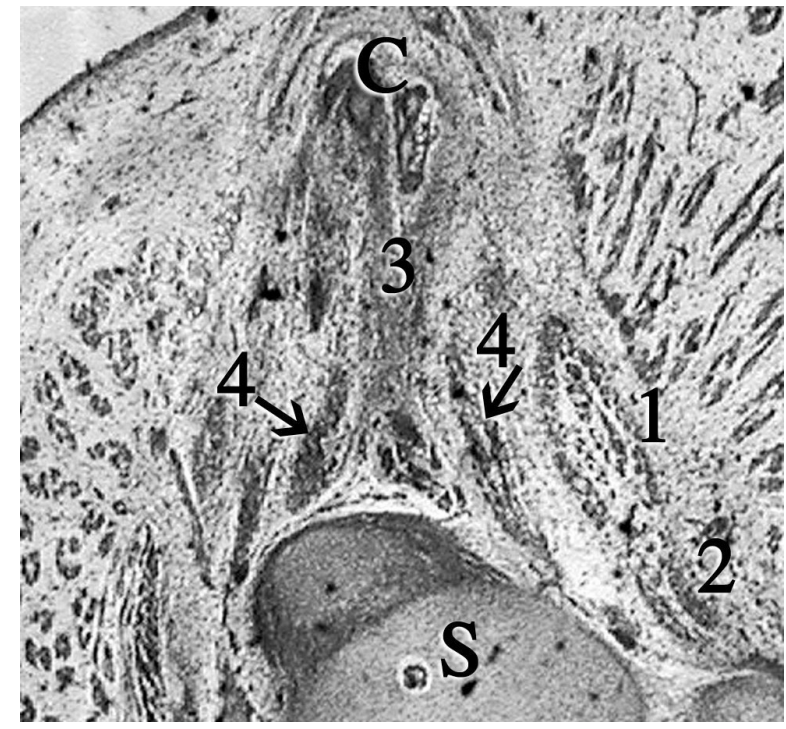

\section{Figure 34mm.6}

$\mathbf{C}$, tip of os coccygis (last vertebra); $\mathbf{S}$, os sacrum; $\mathbf{1}$, ventral part of $\mathrm{m}$. coccygeus; $\mathbf{2}$, dorsal part of $\mathrm{m}$. coccygeus (ligamentum sacrospinale); 3 , ligamentum sacrococcygeum ventrale; $\mathbf{4}, \mathrm{m}$. sacrococcygeus ventralis.

\subsubsection{D-reconstruction}

Oblique view from above on the pelvic diaphragm (Figure 34mm.7)

This picture of the 3D-reconstruction is taken from above, showing the (right) developing pelvic diaphragm from the inside of the pelvis. In the lower right corner is the os sacrum. In the upper left corner the symphysis pubica can be noted

The left and right corpus ossis pubis meet in the midline and are forming the symphysis pubica (2). The rectum and sinus urogenitalis, together forming part of the corpus pelvinum, have been left out in this reconstruction to give a better view on the muscles of the pelvic diaphragm.

In red the reconstruction of the $\mathrm{m}$. obturatorius internus is shown. The ventral to dorsal extension from corpus ossis pubis to the corpus ossis ischii is visible. The dorsal extension of the $m$. obturatorius internus is about as far as in the 50 $\mathrm{mm}$ fetus. Dorsally it does not completely cover the ramus and corpus ossis ischii. The $\mathrm{m}$. obturatorius internus itself can also not be seen leaving the pelvis to insert on the head of the femur. The fascia of the muscle however does, but it is not reconstructed. On the ventral and cranial side the $\mathrm{m}$. obturatorius does not reach the lower margin of the ramus superior ossis pubis. Covering of the upper half of the foramen obturatum is not present. In the $43 \mathrm{~mm}$ embryo the $\mathrm{m}$. obturatorius internus fills in about three quarters of the foramen obturatum, being absent at the cranial part. A canalis obturatorius as such is not present (1). When comparing the extension of the $\mathrm{m}$. obturatorius internus to the $43 \mathrm{~mm}$ fetus it is clear that the development in the dorsal direction is about the same as in the $43 \mathrm{~mm}$ fetus. The development in the ventral and cranial direction is less compared to the $43 \mathrm{~mm}$ fetus.

In dark blue the reconstruction of the $\mathrm{m}$. levator ani is shown. Near the symphysis pubica it covers the $\mathrm{m}$. obturatorius internus for about a quarter. More distally the $\mathrm{m}$. levator ani covers the $\mathrm{m}$. obturatorius internus for about half. The $\mathrm{m}$. levator ani in this $34 \mathrm{~mm}$ fetus does not reach the level of the future spina ischiadica. The oblique border between the levator ani and the obturatorius internus near its origin at the level of the symphysis pubica is in fact the ATLA, running from the inner aspect of the ramus inferior ossis pubis to the future developing spina ischiadica. The $\mathrm{m}$. levator ani has not yet developed far enough dorsally to reach most of the ATLA. Whether the 
ATLA already reaches the region of the future spina ischiadica cannot be distinguished in the available slides. This reconstruction of the $\mathrm{m}$. levator ani also makes it distinctly clear that the levator ani consist of one single muscle that covers the frontal half of the pelvic outlet. In contrast to the $43 \mathrm{~mm}$ and $50 \mathrm{~mm}$ fetuses it does not yet have the typical triangular shape.

The $\mathrm{m}$. coccygeus is reconstructed in green. Its origin is at the level of the future spina ischiadica and its insertion is on the surface of the last sacral and first coccygeal vertebrae. The $m$. coccygeus covers the dorsal half of the fetal pelvic outlet. When comparing the $m$. coccygeus to the $43 \mathrm{~mm}$ fetus it is clear that the muscle shows about the same development. The dorsal extension is further towards the os sacrum than observed in the $43 \mathrm{~mm}$ fetus. Moreover the space between the $\mathrm{m}$. levator ani and the surface of the os sacrum is broader. This is due to the fact that the dorsal extension of the $\mathrm{m}$. levator ani in the 34 $\mathrm{mm}$ fetus is less than in the $43 \mathrm{~mm}$ fetus. The $\mathrm{m}$. levator ani and the $\mathrm{m}$. coccygeus are two separate muscles, distinguishable from each other by a space filled with connective tissue. Together they close the pelvic outlet.

The $\mathrm{m}$. sacrococcygeus ventralis is not reconstructed in this $34 \mathrm{~mm}$ fetus. It does not cover any part of the actual pelvic outlet and is therefore not considered to belong to the pelvic diaphragm (see the reconstruction of the $50 \mathrm{~mm}$ fetus for a example).

\subsubsection{D-reconstruction}

Frontal (Figure $34 \mathrm{~mm} .8$ ) and caudal (Figure $34 \mathrm{~mm} .9$ ) view of the pelvic diaphragm

Figure $34 \mathrm{~mm} .8$ shows a complete frontal picture of the reconstruction. It is clear that the pelvic outlet of this $43 \mathrm{~mm}$ fetus is also projected in the frontal plain, thus pointing forwards. This is in striking contrast to the more backwards oriented pelvic outlet in adult humans. Formation of the angle at the level of the promontorium and the disappearing of the ventral angle between os sacrum and os coccygis is responsible for this backward shifting of the pelvic outlet present after birth. The sharp angle of the os coccygis to the os sacrum in this fetus is well visible in Figure $34 \mathrm{~mm}$.9. The forward projection of the pelvic diaphragm in this $34 \mathrm{~mm}$ fetus is identical to the $43 \mathrm{~mm}$ and $50 \mathrm{~mm}$ fetuses.

The m. obturatorius internus is reconstructed in red. It covers the lower three quarters of the foramen obturatum. In Figure $34 \mathrm{~mm} .8$ it is well visible that the $\mathrm{m}$. obturatorius internus does only cover the lower part of the foramen obturatum. A clearly defined canalis obturatorius in this $34 \mathrm{~mm}$ fetus is not present, as it is in the $50 \mathrm{~mm}$ fetus.

Again in dark blue the $\mathrm{m}$. levator ani is shown. It runs from the corpus ossis pubis and lower margin of the ramus inferior ossis pubis to the os coccygis. The left and right $\mathrm{m}$. levator ani surround the corpus pelvinum, which is reconstructed in yellow.

The left and right levator ani are each separate muscles and are curved inwards and towards each other at a level between the sinus urogenitalis and the rectum and between the rectum and the os coccygis. This curving in the $34 \mathrm{~mm}$ fetus however is less pronounced than in the $43 \mathrm{~mm}$ en $50 \mathrm{~mm}$ fetuses. The area between the sinus urogenitalis and the rectum will form the centrum tendineum as the developing left and right levator ani will eventually reach the centrum tendineum. The actual developing centrum tendineum is present in the $50 \mathrm{~mm}$ fetus but not in the $34 \mathrm{~mm}$ fetus. Behind the rectum, in front of the os coccygis, the left and right levator ani will eventually reach the developing ligamentum anococcygeum. The distance between the left and right $\mathrm{m}$. levator ani at this point is less than in the $43 \mathrm{~mm}$ fetus. Closure of the pelvic diaphragm in the midline is not present in this fetal stage. Compared to the 43 $\mathrm{mm}$ fetus, closure of the pelvic diaphragm in the 
midline is less advanced in this $34 \mathrm{~mm}$ fetus. The insertion of the $\mathrm{m}$. levator ani onto the surface of the os coccygis is also not yet completed. A small gap is still present, formed by connective tissue that is not reconstructed.

The $\mathrm{m}$. coccygeus, reconstructed in green, appears to be just a little thicker than the $\mathrm{m}$. levator ani. In the $50 \mathrm{~mm}$ fetus the $\mathrm{m}$. coccygeus is in fact much larger. The position of the $\mathrm{m}$. coccygeus is more lateral in relation to the $\mathrm{m}$. levator ani. The two muscles show what looks like a 'roof tile' formation. This is the same spatial po- sition as in the $43 \mathrm{~mm}$ and $50 \mathrm{~mm}$ fetuses.

A close look at Figure $34 \mathrm{~mm} .9$ suggests that the pelvic diaphragm consists of four quadrants, as it does in the older fetuses. The ventral left and ventral right quadrants are filled by the left and right $\mathrm{m}$. levator ani and the dorsal quadrants by the $\mathrm{m}$. coccygeus respectively. Compared to the $43 \mathrm{~mm}$ fetus, the covering of the dorsal quadrants by the $\mathrm{m}$. coccygeus is a little more dorsally directed in this $34 \mathrm{~mm}$ fetus. The covering of the ventral quadrants by the $\mathrm{m}$. levator ani however is clearly less advanced in the $34 \mathrm{~mm}$ fetus.

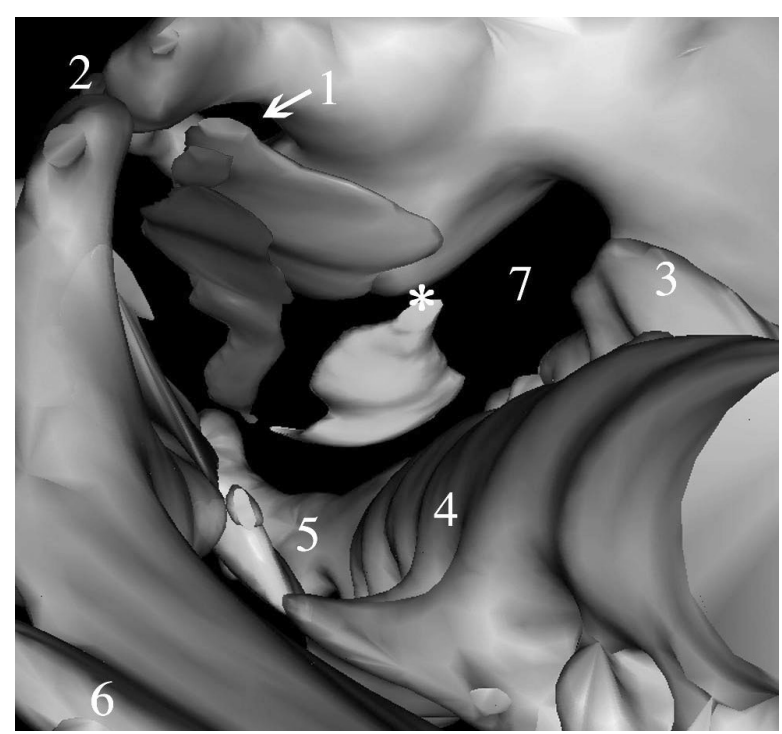

Figure 34mm.7

View from above, on the pelvic diaphragm.

$\mathbf{1}$, foramen obturatum; $\mathbf{2}$, symphysis pubica; $\mathbf{3}$, pars lateralis os sacrum; $\mathbf{4}$, os sacrum; $\mathbf{5}$, os coccygis; $\mathbf{6}$, ala ossis ilii; $\mathbf{7}$, foramen ischiadicum majus; *, future spina ischiadica; red, m. obturatorius internus; blue, m. levator ani; green, m. coccygeus. 


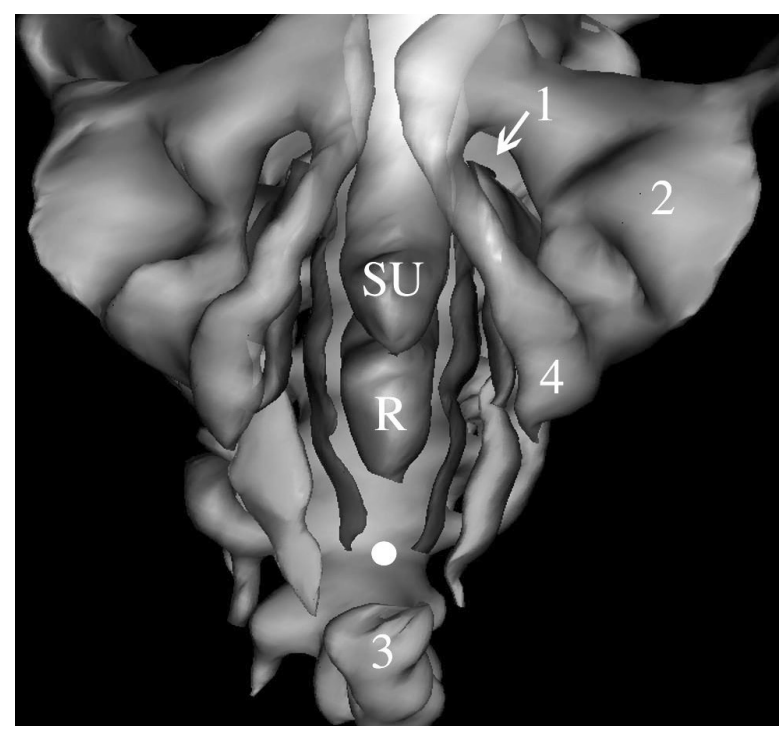

\section{Figure 34mm.8}

Frontal view of the pelvic diaphragm.

$\mathbf{R}$, rectum; SU, sinus urogenitalis; $\mathbf{1}$, foramen obturatum; $\mathbf{2}$,

acetabulum; $\mathbf{3}$, os coccygis; $\mathbf{4}$, ramus ossis ischii; white dot, future ligamentum anococcygeum; red, $\mathrm{m}$. obturatorius internus; blue, $\mathrm{m}$. levator ani; green, m. coccygeus.

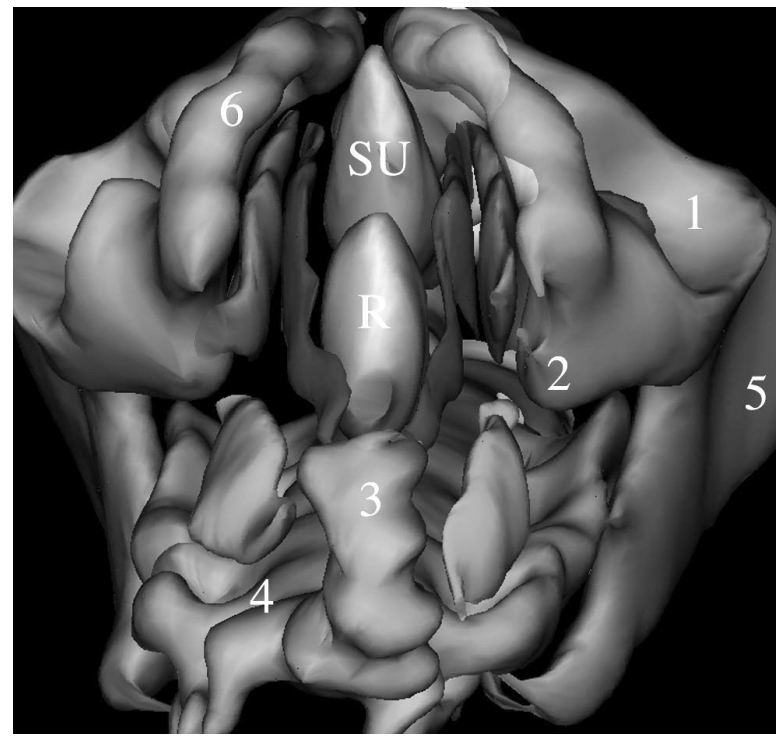

\section{Figure 34mm.9}

View of the pelvic diaphragm from below.

$\mathbf{R}$, rectum; SU, sinus urogenitalis; $\mathbf{1}$, acetabulum; $\mathbf{2}$, ramus ossis ischii at level of developing spina ischiadica; $\mathbf{3}$, os coccygis; $\mathbf{4}$, os sacrum; 5, os ilium (ala ossis ilii); $\mathbf{6}$, ramus inferior ossis pubis; red, $\mathrm{m}$. obturatorius internus; blue, $\mathrm{m}$. levator ani; green, $\mathrm{m}$. coccygeus. 


\section{PART 3}

\section{Embryonal Period}

CONTENTS:

3.1 - StAGE 23: 28 MM AND 30 MM, \pm 58-59 DAYS

3.2 - STAGE 21: 22 MM AND 23 MM, \pm 53-54 DAYS

3.3 - Stage 20: 20 MM AND $21 \mathrm{Mm}, \pm 52$ Days

3.4 - Stage 18-19: 17 MM, \pm 49 DAYs

3.5 - STAGE 17 AND EARLIER 


\subsection{Stage 23}

\section{$28 \mathrm{~mm}$ (WK 1451) and $30 \mathrm{~mm}$ (WK 7652) \pm 58-59 days}

\subsubsection{General features}

These embryos with a CRL of $28 \mathrm{~mm}$ and $30 \mathrm{~mm}$ respectively are about $81 / 2$ weeks (58-59 days) post conception. The embryos are in their developmental stage 23 according to the subdivision by Streeter [1942-1951, described in Gribnau, 1981]. This stage is the end of the embryonic development, thus just before entering their fetal period. This embryological stage is characterized by the complete separation of the fingers and the toes. The embryos are cut transverse in $10 \mu \mathrm{m}$ sections and stained with HE (see Table 2).

Figure $28 \mathrm{~mm} .1$ shows a section through the pelvic cavity of the $28 \mathrm{~mm}$ embryo. The pelvic cavity of the $30 \mathrm{~mm}$ embryo has an identical appearance. In between the allantois (future bladder) and the hindgut (future rectum), the urogenital septum is localized. In the centre of this urogenital septum are the mesonephric ducts (Wolffian) laterally and the partially fused paramesonephric ducts (Mullerian) medially. Both embryos are female.

As in the $34 \mathrm{~mm}$ fetus, the $28 \mathrm{~mm}$ embryo is cut obliquely medio-laterally. This orientation is well illustrated in Figure $28 \mathrm{~mm}$.1. The left side of the section runs at the level of the foramen obturatum and the acetabulum. The right side of the section is located above the ramus superior ossis pubis at the level of the $\mathrm{m}$. psoas major. On the left side the nervus obturatorius can be seen leaving the pelvic cavity. At the right side the arteria umbilicalis is clearly visible. The developing hindgut, the developing uterus/cervix and the allantois (together forming the corpus pelvinum) are embedded in developing connective tissue. The density of the developing connective tissue appears to be the same as in the $34 \mathrm{~mm}$ fetus but there is hardly any sign of fat present. The extension of the peritoneal cavity as a rectouterine pouch is visible, but the presence of an uterovesical pouch is less defined as in the $34 \mathrm{~mm}$ and older fetuses.

The development of the bony pelvis is not yet complete in these embryos. The bones present are all outlined only in cartilage. No ossification is noted. Nevertheless, the corpus ossis ilii, the corpus ossis ischii and the corpus ossis pubis can be identified individually. The individual development of especially the corpus ossis pubis and corpus ossis ischii is more clearly outlined in developing cartilage compared to the older fetuses. The corpus ossis ilii is completely present but it's ala ossis ilii is far less developed than it is in later stages. The tuber ischiadicum of the os ischii is solely present as a mesenchymal condensation. The spina ischiadica however is far less outlined in mesenchyme as it is in the $34 \mathrm{~mm}$ and older fetuses.

The os sacrum of the embryos is fully developed in cartilage. Fusion of the vertebrae is not yet present. Connections of the os sacrum to the os coxae is formed through mesenchyme connecting the pars lateralis of the os sacrum to the os coxae. The ligg. sacroiliaca interossea, as present in the older fetuses, can not be identified as such. The os coccygis is formed in cartilage and shows fusion of the third tot fifth vertebra.

After evaluating the reconstruction of the cartilaginous pelvis of the $28 \mathrm{~mm}$ fetus it is apparent, like the $50 \mathrm{~mm}, 43 \mathrm{~mm}$ and $34 \mathrm{~mm}$ fetuses, that the typical angle at the level of the promontorium is not visible and that the os coccygis makes a far more sharp angle ventrally. Absence of the angle at the level of the promontorium and the sharp angle of the os coccygis seems responsible for the ventral position of the pelvic outlet present in this embryonic stage. This is in accordance with the older fetuses.

\subsubsection{Musculus obturatorius internus}

Similar to the later stages the $\mathrm{m}$. obturatorius internus itself does not completely cover the foramen obturatum. Especially at the level of the os 
pubis the muscle fibers do not reach the surface of the inner aspect of the corpus ossis pubis, i.e. the ramus superior and the ramus inferior ossis pubis. The fascia of the $\mathrm{m}$. obturatorius internus however appears not to be attached to the corpus ossis pubis yet, however difficult to see in the available material. This is in striking contrast with the $34 \mathrm{~mm}$ fetus where the fascia of the $\mathrm{m}$. obturatorius internus is already fixed to the inner aspect of the os pubis. This must mean that the ventral part of the foramen obturatum is not covered by the $\mathrm{m}$. obturatorius internus at the end of the embryological period. On the dorsal side the $\mathrm{m}$. obturatorius internus reaches the most dorsal part of the ramus ossis ischii only at the level just above the developing tuber ischiadicum. The muscle itself cannot be located outside the pelvic cavity as it does in the $50 \mathrm{~mm}$ fetus, where it can be seen to insert on the femur. In fact, only the fascia of the $\mathrm{m}$. obturatorius internus extends to the trochanter major femoris where it clearly inserts.

At its lateral side the $\mathrm{m}$. obturatorius is covered by the membrana obturatoria. The membrana obturatoria in the $28 \mathrm{~mm}$ embryo is thicker than it is in the $34 \mathrm{~mm}$ fetus. On the other side of the membrana obturatoria the $\mathrm{m}$. obturatorius externus is clearly developed (Figure $28 \mathrm{~mm} .2$ ).

The nervus obturatorius can be seen leaving the pelvis just below the ramus superior ossis pubis, following the sections. The nerve, however, is free from the $\mathrm{m}$. obturatorius internus. The muscle starts to appear below the level of the nervus obturatorius and is not present at the ventral or at the dorsal side of the nervus obturatorius. The cranial extension of the $\mathrm{m}$. obturatorius internus is about the same as it is in the $34 \mathrm{~mm}$ fetus. This means that the foramen obturatum is not covered by the $\mathrm{m}$. obturatorius internus on the cranial side. The canalis obturatorius as such is not yet constituted.

Just below the level of the symphysis, on the inner aspect of the ramus inferior ossis pubis, a broad band of connective tissue can be seen. It runs towards the sinus urogenitalis and eventually radiating around it. This is the developing pubovesical ligament (considered as the ventral part of the ATLA in adult human anatomy) and the endopelvic fascia. The development of the ligament and fascia is the same in the $34 \mathrm{~mm}$ fetus.

In between the developing endopelvic fascia and the $\mathrm{m}$. obturatorius internus a thin and dense band of connective tissue appears. It is located at a level that is about halfway the foramen obturatum and well below the nervus obturatorius. This band of connective tissue is the arcus tendineus levatoris ani (ATLA). The ATLA shows a similar development as it does in the $34 \mathrm{~mm}$ fetus. It cannot be discerned at the inner aspect of the ramus inferior ossis pubis ventrally. Dorsally it extends about as far as it does in the $34 \mathrm{~mm}$ fetus. When it arises it covers about a quarter of the medial aspect of the $\mathrm{m}$. obturatorius. It fades away in loose connective tissue that covers the ventral half of the $\mathrm{m}$. obturatorius internus.

\subsubsection{Musculus levator ani}

Following the ATLA through the embryo it shows a gradual thickening on the ventral side as muscle fibers start to originate. The muscle fibers are in a straight angle to the ATLA. When it originates the $\mathrm{m}$. levator ani does not show such a close relationship with the inner aspect of the ramus inferior ossis pubis as it does in the older fetuses. The distance between the left and right os pubis at the level of the muscle's origin is bigger than it is in the $34 \mathrm{~mm}$ fetus. The ventral margin of the first appearing muscle fibers is also further away from the os pubis compared to the $34 \mathrm{~mm}$ fetus. The gap is filled by, until now, undefined connective tissue that will probably play a role in the development of the diaphragma urogenitalis. At its origin the dorsal extension of the $\mathrm{m}$. levator ani is over about a quarter of the medial aspect of the $\mathrm{m}$. obturatorius internus. This configuration is also found in the $34 \mathrm{~mm}$ fetus. In the $43 \mathrm{~mm}$ fetus it immediately covered about half the medial aspect 
and in the $50 \mathrm{~mm}$ fetus more than half.

The moment it originates and can be recognized it is again clear that the $\mathrm{m}$. levator ani is one single muscle. It stays separated from the $\mathrm{m}$. obturatorius internus by a small margin of developing connective tissue. As in the $34 \mathrm{~mm}$ and $43 \mathrm{~mm}$ fetus this separate, but close relationship is maintained all the way to the lower end of the corpus ossis ischii at the point where the $\mathrm{m}$. obturatorius internus leaves the pelvis. Below this point, above the developing ramus ossis ischii, this relationship is lost as the $\mathrm{m}$. levator ani starts to extend more medially. There appears an increasing gap between the $\mathrm{m}$. levator ani and $\mathrm{m}$. obturatorius internus that is now filled with loose connective tissue. This gap is the fossa ischiorectalis that is bigger compared to the older fetuses. At the level of insertion of the m. obturatorius internus near the developing tuber ischiadicum the nervus pudendus starts to appear.

Progressing caudally through the sections the thickness of the $\mathrm{m}$. levator ani increases especially on its ventral side. The ventral to dorsal length increases and at the upper level of the ramus ossis ischii the $\mathrm{m}$. levator ani has developed to a muscle covering the $\mathrm{m}$. obturatorius internus completely (Figure $28 \mathrm{~mm} .3$ ). A decreasing ventral-dorsal length of the $\mathrm{m}$. obturatorius internus is responsible for this complete covering. The ventral to dorsal extension of the $\mathrm{m}$. levator ani is similar to the $34 \mathrm{~mm}$ fetus. At a level just above the developing tuber ischiadicum the dorsal extension of the $\mathrm{m}$. levator ani surpasses the $\mathrm{m}$. obturatorius internus. At this point the $\mathrm{m}$. levator ani reaches its maximal ventral to dorsal extension. Apart from its fascia the $\mathrm{m}$. levator ani is not fixed to the dorsal end of the corpus ossis ischii. Behind the $\mathrm{m}$. levator ani a separate muscle starts to appear. This is the m. coccygeus.

Passing around the sinus urogenitalis the ventral side of the $\mathrm{m}$. levator ani is attached to connective tissue that appears to be the developing diaphragma (hiatus) urogenitalis. The $\mathrm{m}$. leva- tor ani is totally free from the sinus urogenitalis. It is lying closely adjacent to it. It also shows some inward curving but stays unrelated to this sinus. Behind the sinus urogenitalis no connection can be identified between the left and right $\mathrm{m}$. levator ani. They are separated from each other by connective tissue that does not have the appearance of a centrum tendineum like it has in the $50 \mathrm{~mm}$ fetus. In these embryos the relationship of the $\mathrm{m}$. levator ani to the sinus urogenitalis is comparable to the $34 \mathrm{~mm}$ and $43 \mathrm{~mm}$ fetuses, in which it also stays free.

In between the sinus urogenitalis and the rectum the $\mathrm{m}$. sphincter ani externus starts to appear in the more caudal sections. The deep part of the $\mathrm{m}$. sphincter externus seems to have a closer relationship with the $\mathrm{m}$. levator ani compared to the older fetuses. The $\mathrm{m}$. levator ani is attached to the $\mathrm{m}$. sphincter ani externus. It is not attached to the rectum (Figure 28mm.4). Behind the rectum the left and right $\mathrm{m}$. levator ani start to run towards the midline. Eventually the left and right $\mathrm{m}$. levator ani are nearing each other and the most dorsal part of the $\mathrm{m}$. sphincter ani externus via connective tissue. This connective tissue can be followed from the deep part of the $\mathrm{m}$. sphincter ani externus to the tip of the os coccygis. It is the developing ligamentum anococcygeum (Figure $28 \mathrm{~mm} .5$ ). Compared to the $34 \mathrm{~mm}$ fetus these structures are less defined.

\subsubsection{Musculus coccygeus}

At the surface of the most dorsal part of the corpus ossis ischii, i.e. the future spina ischiadica, the $\mathrm{m}$. coccygeus originates (Figure $28 \mathrm{~mm} .4$ ). The fascia of the $\mathrm{m}$. levator ani also attaches to the surface of the os ischii at this point. Attachment is made by connective tissue that is the arcus tendineus levatoris ani. Comparable to the $34 \mathrm{~mm}$ fetus, the ATLA as a well defined structure cannot be identified at the level of the os ischii and developing spina ischiadica.

After its origin the m. coccygeus increas- 
es in volume as it progresses towards the os coccygis. The way it increases in volume and the total volume reached is about the same as in the 34 $\mathrm{mm}$ fetus. Like in the later stages the m. coccygeus soon appears to consist of two parts (Figure $28 \mathrm{~mm} .5$ ). The division between the two parts is less defined than in the older fetuses. The dorsal part has the same size compared to the older fetuses and is larger than its ventral part. The dorsal part spreads out towards the surface of the os sacrum and becomes the ligamentum sacrospinale.

The ventral part, or actual m. coccygeus, travels towards the midline. Its fascia can be followed up to its insertion on the lateral aspect of the last coccygeal vertebrae. The $\mathrm{m}$. coccygeus has no relationship with the ligamentum anococcygeum that inserts on the tip of the os coccygis (Figure 28mm.5).

The $\mathrm{m}$. coccygeus has no relationship or contact with the $\mathrm{m}$. levator ani. The $\mathrm{m}$. coccygeus runs dorsal and lateral from the $\mathrm{m}$. levator ani and is separated by a border of loose connective tissue. The extension of this border of connective tissue is the same as in the $34 \mathrm{~mm}$ fetus. The $\mathrm{m}$. coccygeus can also be followed further towards the os coccygis than the $\mathrm{m}$. levator ani. The levator ani inserts on to the os coccygis via the ligamentum anococcygeum.

\subsubsection{Musculus sacrococcygeus ventralis}

The $\mathrm{m}$. sacrococcygeus ventralis is identified as a muscle lying medially from the $\mathrm{m}$. coccygeus. Compared to the older fetuses it is much smaller and less outlined. It originates from the pelvic surface of the os sacrum and inserts on the lateral aspect of the os coccygis. One should look into the description of the $50 \mathrm{~mm}$ fetus for further details on the $\mathrm{m}$. sacrococcygeus.

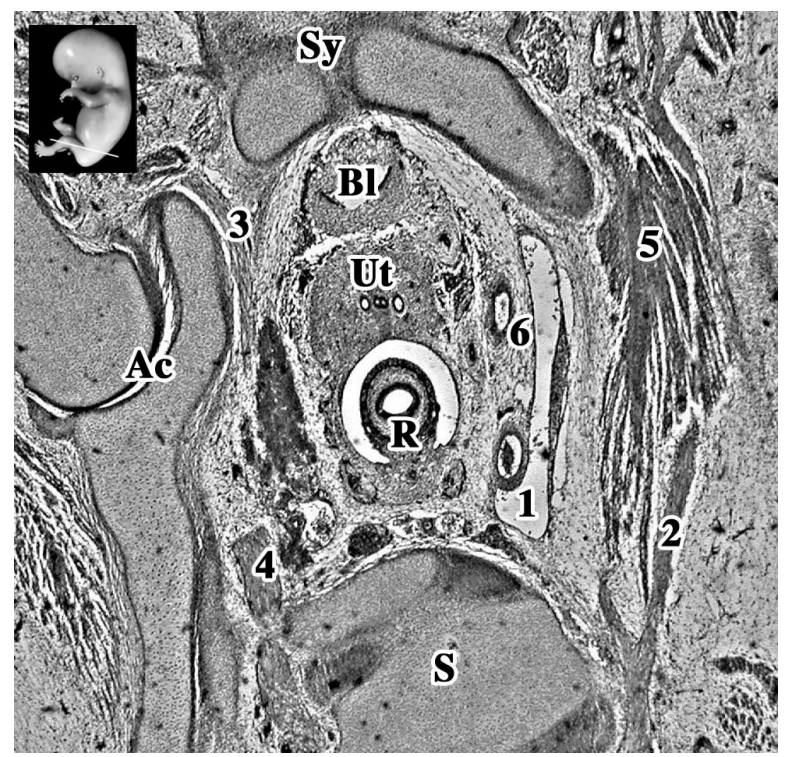

Figure 28mm.1

Insert: level of section indicated by a white line.

Ac, acetabulum; BI, allantois (bladder); R, hindgut; S, last lumbar vertebra; Sy, symphysis pubica; Ut, uterus (cervix); 1, a.v. iliaca externa; $\mathbf{2}$, nervus femoralis; $\mathbf{3}$, nervus obturatorius; $\mathbf{4}$, nervus lumbalis $\mathrm{V} ; \mathbf{5}$, m. psoas major; $\mathbf{6}$, arteria umbilicalis. 


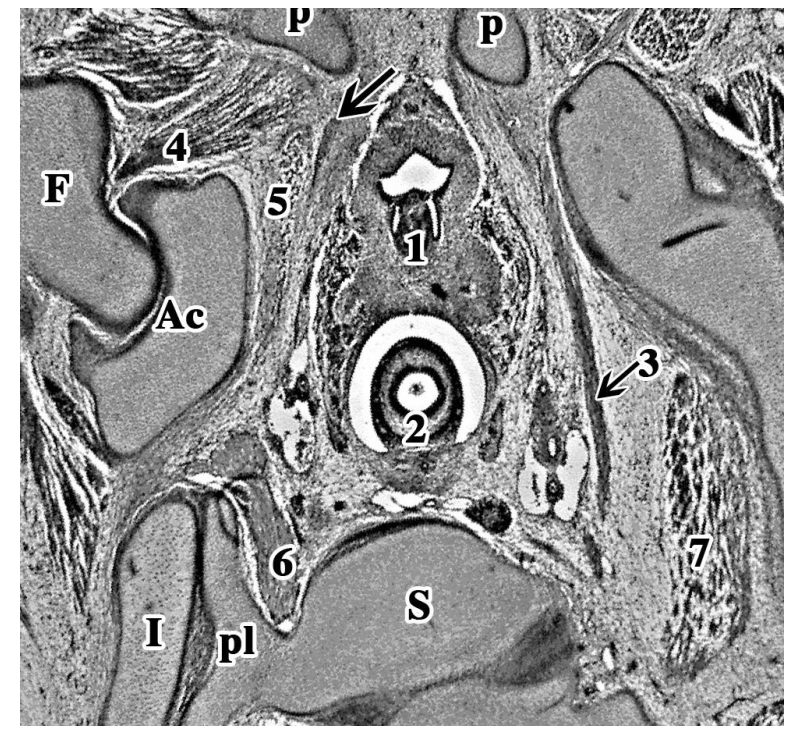

Figure 28mm.2

Ac, acetabulum; F, femur; I, os ilium; $\mathbf{P}$, os pubis (ramus inferior); $\mathbf{p l}$, pars lateralis os sacrum; $\mathbf{S}$, os sacrum; $\mathbf{1}$, sinus urogenitalis; $\mathbf{2}$, hindgut; 3 (+arrow), nervus obturatorius; $\mathbf{4}, \mathrm{m}$. obturatorius externus; $\mathbf{5}, \mathrm{m}$. obturatorius internus; $\mathbf{6}$, plexus lumbosacralis (ramus ventralis nervus sacralis I); 7, m. psoas major; black arrow, arcus tendineus levatoris ani.

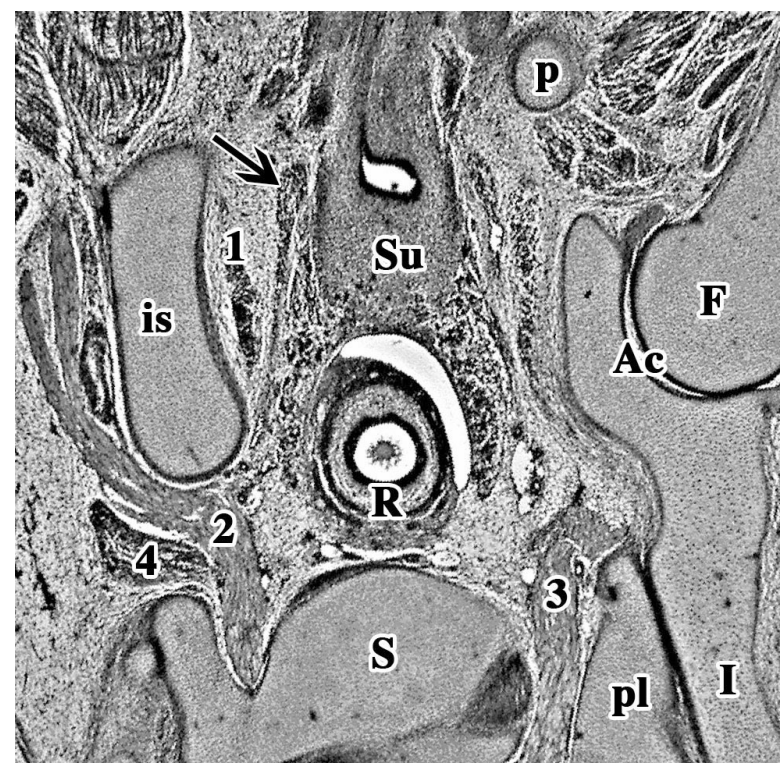

Figure 28mm.3

Ac, acetabulum; $\mathbf{F}$, femur (caput); is, os ischii; I, os ilium; $\mathbf{p}$, os pubis (ramus inferior); $\mathbf{p l}$, pars lateralis os sacrum; $\mathbf{R}$, hindgut; $\mathbf{S}$, os sacrum; $\mathbf{S u}$, sinus urogenitalis; $\mathbf{1}, \mathrm{m}$. obturatorius internus; $\mathbf{2}$, nervus/plexus ischiadicus; $\mathbf{3}$, nervus sacralis I (plexus lumbosacralis); 4, m. piriformis; black arrow, m. levator ani. 

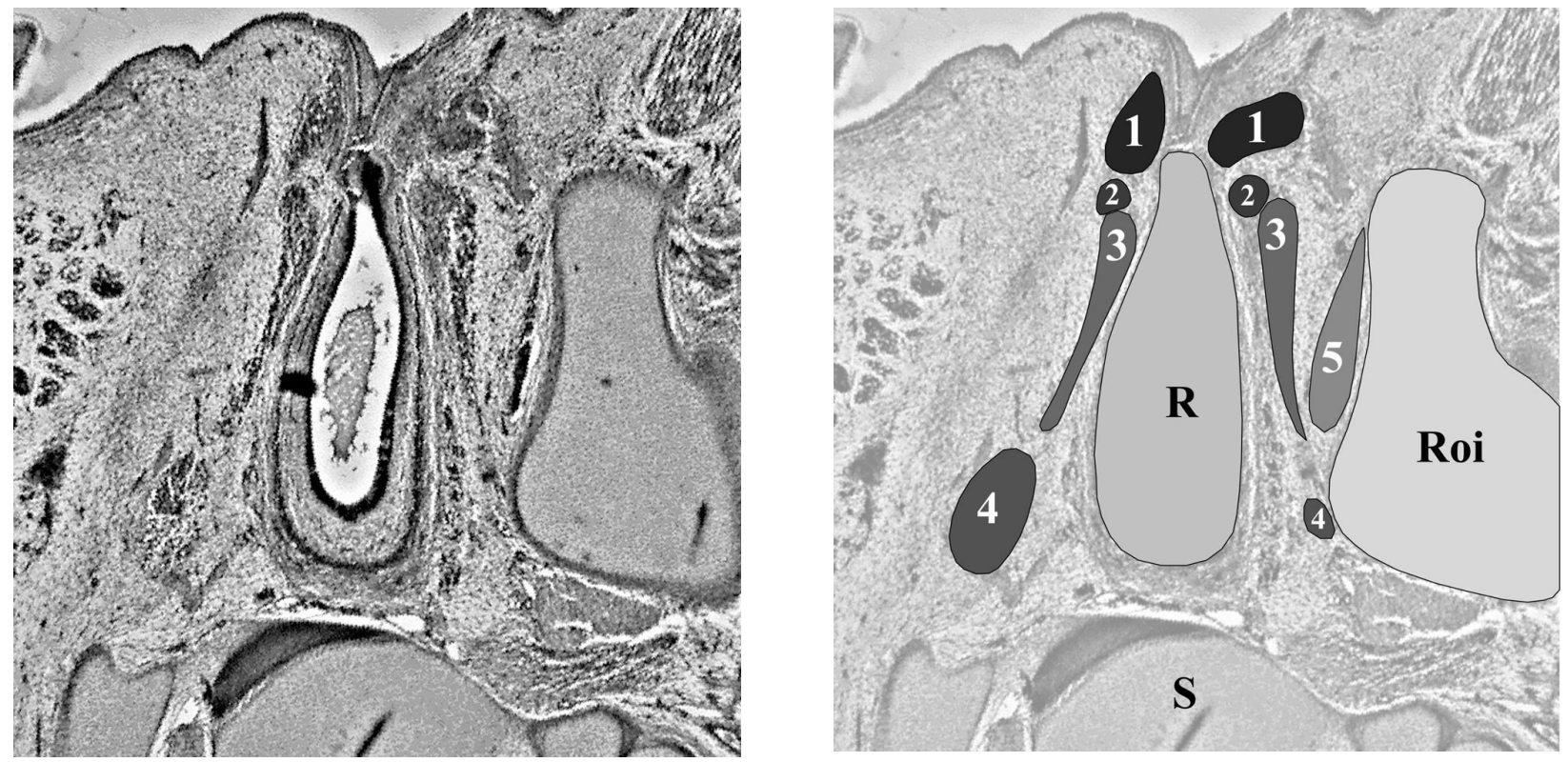

Figure 28mm.4

$\mathbf{R}$, hindgut; $\mathbf{S}$, os sacrum; Roi, ramus/corpus ossis ischii; 1, superficial part of m. sphincter ani externus; 2, deep part of m. sphincter ani externus; $\mathbf{3}, \mathrm{m}$. levator ani; $\mathbf{4}, \mathrm{m}$. coccygeus; $\mathbf{5}, \mathrm{m}$. obturatorius internus.

Although hardly visible, there is a small border between the superficial and deep part of the external sphincter. There is a close relationship between the deep part of the $\mathrm{m}$. levator ani and the deep part of the external sphincter. They are directly attached to each other.
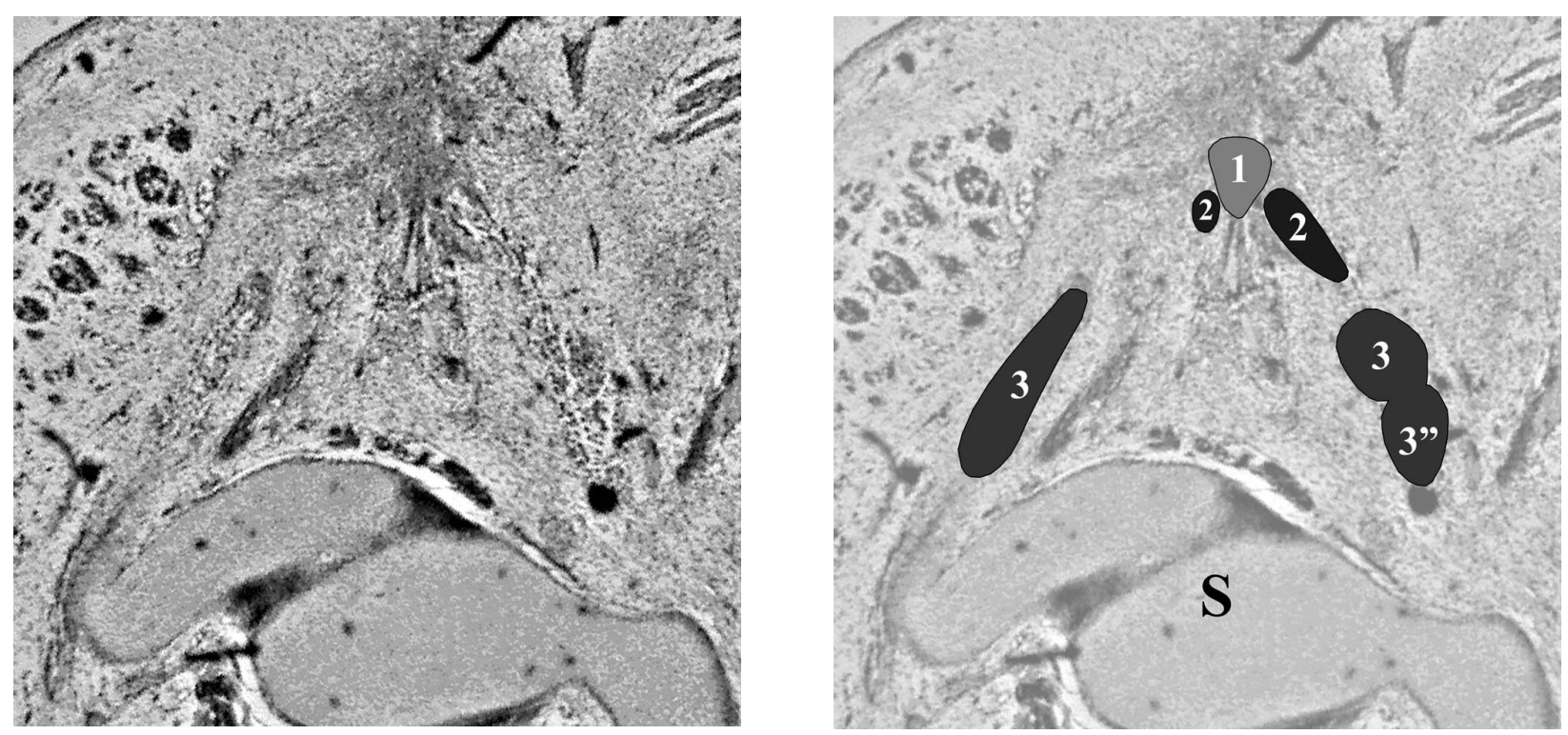

Figure 28mm.5

S, os sacrum; 1, developing ligamentum anococcygeum; 2, m. levator ani; $\mathbf{3}, \mathrm{m}$. coccygeus; 3 ", dorsal part of m. coccygeus or future ligamentum sacrospinale.

The m. coccygeus on the left side shows the same division in a ventral and dorsal part as seen on the right side, in more rostral sections. 


\subsubsection{D-reconstruction}

Oblique view from above on the pelvic diaphragm (Figure 28mm.6)

This picture of the 3D-reconstruction is taken from above, showing the (right) developing pelvic diaphragm from the inside of the pelvis. In the lower right corner is the os sacrum. In the upper left corner the symphysis pubica.

The left and right corpus ossis pubis meet in the midline and are forming the symphysis pubica (2). The rectum and sinus urogenitalis, together forming part of the corpus pelvinum, have been left out in this reconstruction to give a better view on the muscles of the pelvic diaphragm.

In red the reconstruction of the $\mathrm{m}$. obturatorius internus is shown. The ventral to dorsal extension from corpus ossis pubis to the corpus ossis ischii is visible. The dorsal extension of the $\mathrm{m}$. obturatorius internus is about as far as in the 34 $\mathrm{mm}$ fetus. Dorsally it does not completely cover the ramus and corpus ossis ischii. The muscular volume of the $\mathrm{m}$. obturatorius internus itself can also not be seen leaving the pelvis to insert on the head of the femur. The fascia of the muscle however does, but is not reconstructed. On the ventral and cranial side the $\mathrm{m}$. obturatorius does not reach the lower margin of the ramus superior ossis pubis. In the $34 \mathrm{~mm}$ embryo the $\mathrm{m}$. obturatorius internus fills in about three quarters of the foramen obturatum, being absent at its cranial part. On the ventral side the $\mathrm{m}$. obturatorius internus covers about half the foramen obturatum (Figure $28 \mathrm{~mm} .7$ ). A canalis obturatorius as such is not present. When comparing the extension of the $\mathrm{m}$. obturatorius internus to the $34 \mathrm{~mm}$ fetus it is clear that the development in the dorsal direction is about the same. The development in the ventral and cranial direction is less compared to the $34 \mathrm{~mm}$ fetus.

In dark blue the reconstruction of the $\mathrm{m}$. levator ani is shown. Near the symphysis pubica it covers the $\mathrm{m}$. obturatorius internus for about a quarter, comparable to the $34 \mathrm{~mm}$ fetus. More distally the $\mathrm{m}$. levator ani covers the $\mathrm{m}$. obturatorius internus for about half. The muscular volume of the $\mathrm{m}$. levator ani in this $28 \mathrm{~mm}$ embryo does not reach the level of the future spina ischiadica. The border between the levator ani and the obturatorius internus near its origin at the level of the symphysis pubica is in fact the ATLA, running from the inner aspect of the ramus inferior ossis pubis to the future developing spina ischiadica. The $\mathrm{m}$. levator ani has not yet developed far enough dorsally to reach most of the ATLA. Whether the ATLA already reaches the region of the future spina ischiadica cannot be distinguished in the available sections. This reconstruction of the $\mathrm{m}$. levator ani also makes it distinctly clear that the levator ani consist of one single muscle that covers the frontal half of the pelvic outlet. The dorsal extension of the muscle is less developed compared to the $34 \mathrm{~mm}$ fetus, especially at the level of the $\mathrm{m}$. coccygeus. In contrast to the $43 \mathrm{~mm}$ and $50 \mathrm{~mm}$ fetuses it does not yet have the typical triangular shape. It is in this sense comparable to the 34 $\mathrm{mm}$ fetus.

The $\mathrm{m}$. coccygeus is reconstructed in green. Its origin is at the level of the future spina ischiadica and its direction is towards the surface of the last sacral and first coccygeal vertebrae. The $m$. coccygeus covers the dorsal half of the fetal pelvic outlet. When comparing the m. coccygeus to the $34 \mathrm{~mm}$ fetus it is clear that the muscle volume shows a slightly lesser development. The space between the $\mathrm{m}$. coccygeus and the surface of the os sacrum is a bit broader. This is due to the fact that the dorsal extension of the $m$. coccygeus in this $28 \mathrm{~mm}$ embryo is less than in the $34 \mathrm{~mm}$ fetus. The $\mathrm{m}$. levator ani and the $\mathrm{m}$. coccygeus are two separate muscles, distinguishable from each other by a space filled with connective tissue.

The $\mathrm{m}$. sacrococcygeus ventralis is not reconstructed in this $28 \mathrm{~mm}$ embryo. It does not cover any part of the actual pelvic outlet and is 
therefore not considered to belong to the pelvic diaphragm (see the reconstruction of the $50 \mathrm{~mm}$ fetus for a example).

\subsubsection{D-reconstruction}

Frontal (Figure 28mm.8) and caudal (Figure 28mm.9) view of the pelvic diaphragm

Figure $28 \mathrm{~mm} .8$ shows a complete frontal picture of the reconstruction. It is clear that the pelvic outlet of this $28 \mathrm{~mm}$ embryo is also projected in the frontal plain, thus pointing forwards. The sharp angle of the os coccygis to the os sacrum in this embryo is well visible in Figure $28 \mathrm{~mm} .8$. The forward projection of the pelvic diaphragm is identical to the older fetuses.

The $\mathrm{m}$. obturatorius internus is reconstructed in red. It covers the lower three quarters and dorsal half of the foramen obturatum (see also Figure $28 \mathrm{~mm} .7$ ). In Figure $28 \mathrm{~mm} .8$ it is also visible that the $\mathrm{m}$. obturatorius internus does only cover the lower part of the foramen obturatum. A clearly defined canalis obturatorius is not present, as in the later stages.

Again in dark blue the $\mathrm{m}$. levator ani is shown. It runs from the corpus ossis pubis and lower margin of the ramus inferior ossis pubis to the os coccygis. The left and right $m$. levator ani surround the corpus pelvinum, which is reconstructed in yellow.

The left and right levator ani are each separate muscles and are curved inwards and towards each other at a level between the rectum and the os coccygis. This curving however is more pronounced than in the $34 \mathrm{~mm}$ fetus. Behind the rectum, in front of the os coccygis, the left and right levator ani will eventually reach the devel- oping ligamentum anococcygeum. The distance between the rectum and the tip of the os coccygis is less than it is in the $34 \mathrm{~mm}$ fetus. This is due to the fact that the os coccygis is slightly more curved towards the rectum. The distance between the left and right $\mathrm{m}$. levator ani at this point is the same as in the $34 \mathrm{~mm}$ fetus. More interesting is the absence of inward curving of the $\mathrm{m}$. levator ani between the sinus urogenitalis and the rectum. Apparently the formation of a future centrum tendineum has not started.

Closure of the pelvic diaphragm in the midline is not present. Compared to the $34 \mathrm{~mm}$ fetus, closure of the pelvic diaphragm in the midline is equally advanced in this $28 \mathrm{~mm}$ embryo. The insertion of the $\mathrm{m}$. levator ani onto the surface of the os coccygis is also not yet completed. A small gap is still present, formed by connective tissue that is not reconstructed.

The $\mathrm{m}$. coccygeus, reconstructed in green, appears to be just a little thicker than the $\mathrm{m}$. levator ani. The volume of the $\mathrm{m}$. coccygeus is about the same as in the $34 \mathrm{~mm}$ fetus, only just slightly smaller. The position of the $m$. coccygeus is more lateral in relation to the $\mathrm{m}$. levator ani. The two muscles show what looks like a 'roof tile' formation. This is the same spatial position as in the other described fetal stages.

A close look at Figure $28 \mathrm{~mm} .9$ suggests that the pelvic diaphragm consists of four quadrants, as it does in the older fetuses. The ventral left and ventral right quadrants are filled by the left and right $\mathrm{m}$. levator ani and the dorsal quadrants by the $\mathrm{m}$. coccygeus respectively. The $\mathrm{m}$. coccygeus again appears slightly smaller than in the $34 \mathrm{~mm}$ fetus. It does not fill the dorsal quadrants as much as it does in the later stages. 
full color illustrations of the photos on this page can be found on page 119-121

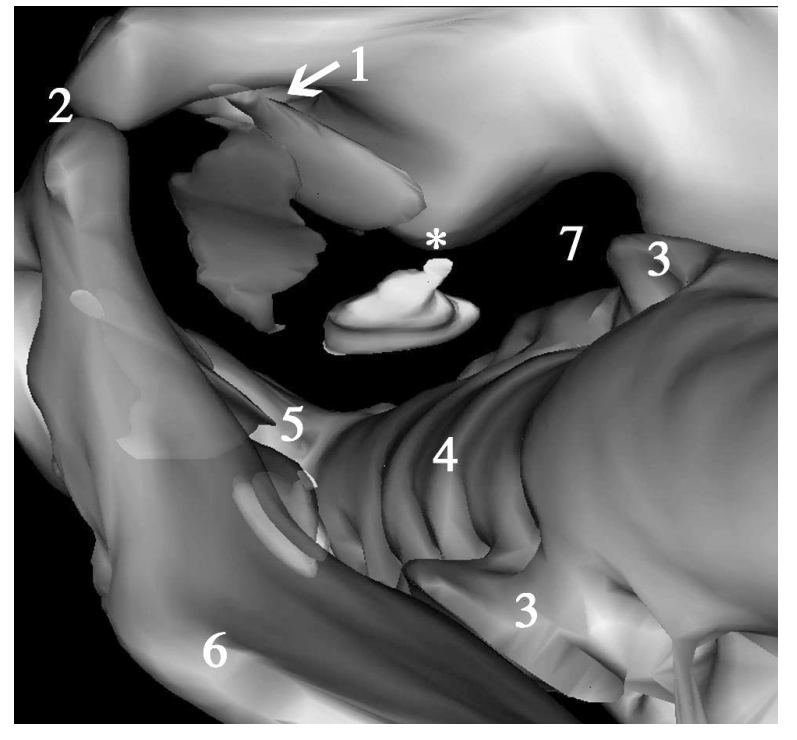

\section{Figure 28mm.6}

View from above on the pelvic diaphragm.

$\mathbf{1}$, foramen obturatum; $\mathbf{2}$, symphysis pubica; $\mathbf{3}$, pars lateralis os sacrum; $\mathbf{4}$, os sacrum; $\mathbf{5}$, os coccygis; $\mathbf{6}$, ala ossis ilii; $\mathbf{7}$, foramen ischiadicum majus; *, future spina ischiadica; red, $\mathrm{m}$. obturatorius internus; blue, $\mathrm{m}$. levator ani; green, $\mathrm{m}$. coccygeus.

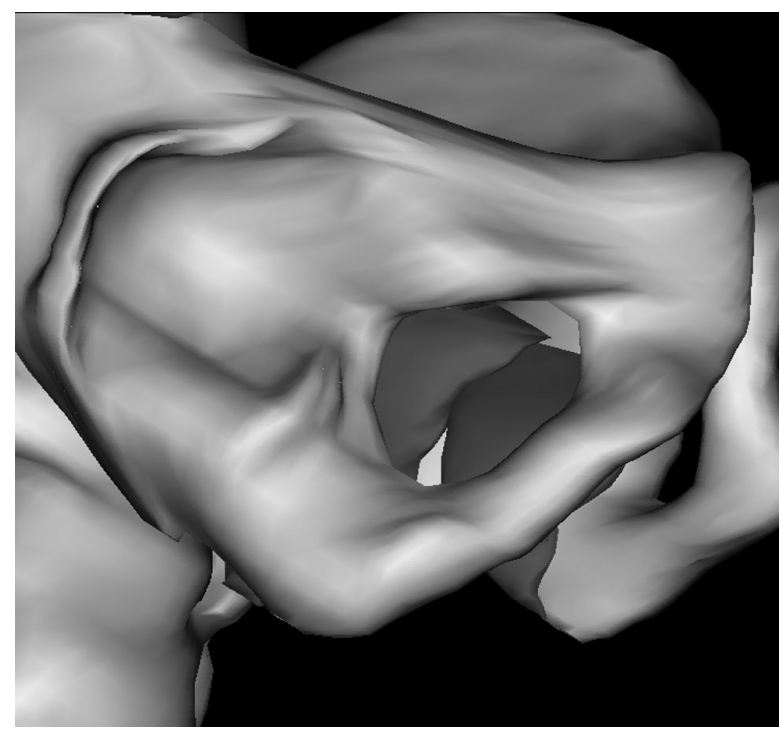

\section{Figure 28mm.7}

View of the right foramen obturatum.

The $\mathrm{m}$. obturatorius internus is reconstructed in red. Note that the muscle does not cover the frontal half and cranial quarter of the foramen obturatum.

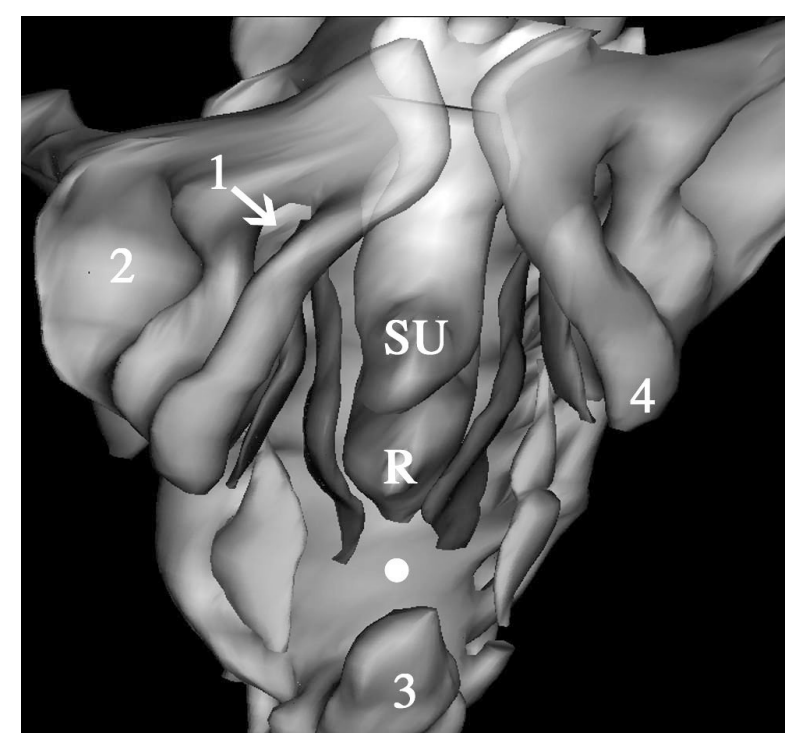

Figure $28 \mathrm{~mm} .8$

Frontal view of the pelvic diaphragm.

$\mathbf{R}$, rectum; SU, sinus urogenitalis; $\mathbf{1}$, foramen obturatum; $\mathbf{2}$,

acetabulum; $\mathbf{3}$, os coccygis; $\mathbf{4}$, ramus ossis ischii; white dot, future ligamentum anococcygeum; red, $\mathrm{m}$. obturatorius internus; blue, $\mathrm{m}$. levator ani; green, $\mathrm{m}$. coccygeus.

Note the absence of the curving between the sinus urogenitalis and the rectum (the future centrum tendineum). 


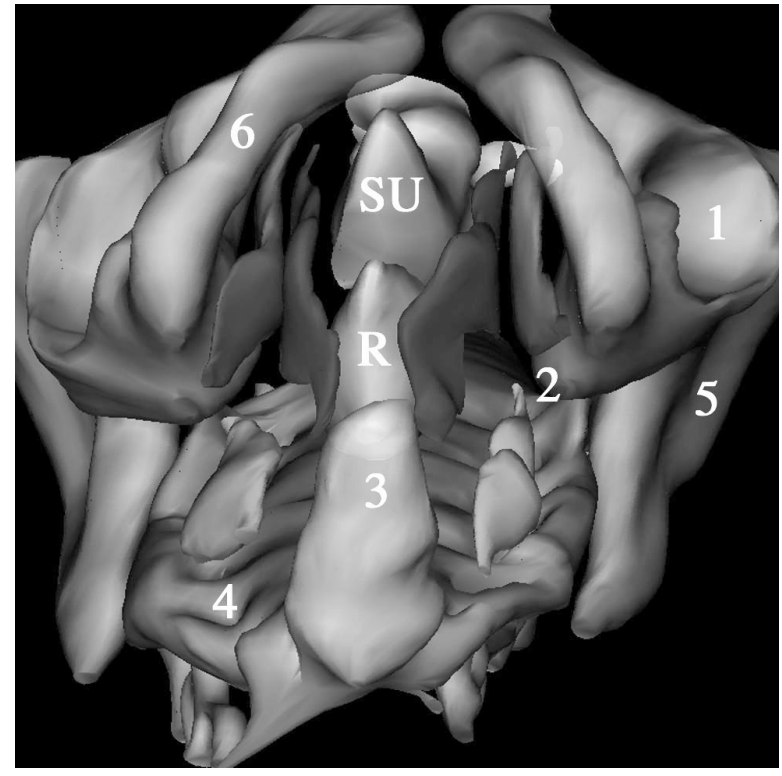

Figure 28mm.9

View of the pelvic diapragm from below.

$\mathbf{R}$, rectum; SU, sinus urogenitalis; $\mathbf{1}$, acetabulum; $\mathbf{2}$, ramus ossis ischii at level of developing spina ischiadica; $\mathbf{3}$, os coccygis; $\mathbf{4}$, os sacrum; 5, os ilium (ala ossis ilii); 6, ramus inferior ossis pubis; red, $\mathrm{m}$. obturatorius internus; blue, $\mathrm{m}$. levator ani; green, $\mathrm{m}$. coccygeus.

\subsection{Stage 21}

\section{$22 \mathrm{~mm}$ (WK 7832) and $23 \mathrm{~mm}$ (WK 1256, WK 548, 5249) \pm 53-54 days}

\subsubsection{General features}

These embryos with a CRL of $22 \mathrm{~mm}$ and $23 \mathrm{~mm}$ respectively are about 7.5 weeks (53-54 days) post conception. The embryos are in their developmental stage 21 according to the subdivision by Streeter [1942-1951, described in Gribnau, 1981]. At this stage the separation of the fingers and toes starts. Distinctive external characteristics are: the distal phalanges of the fingers are already separated; the arms and legs are in a flexed position at the elbows and knees; the hands and feet of both sides are approaching each other and the tips of the toes are separated [Gribnau, 1981]. The embryos are cut transverse in $10 \mu \mathrm{m}$ sections and stained with HE (see Table 2). The description of stage 21 is given by the $23 \mathrm{~mm}$ embryo (WK 1256). The other embryos are in essence the same. If necessary the other stage 21 embryos will be separately discussed.

Figure $23 \mathrm{~mm} .1$ shows a section through the $23 \mathrm{~mm}$ embryo. The developing kidneys (metanephros) are well visible. In between the kidneys is the aorta. Lateral and caudal to the kidneys the urogenital ridge can be seen with the mesonephros and the developing testis. The embryo is male.

The direction of the sections is obliquehorizontal. Due to the strong curving of the embryo at this stage the sections through the pelvis also show in part the upper urogenital system. The orientation of the sections through the pelvis is more frontal . Figure $23 \mathrm{~mm} .1$ shows clearly that the sinus urogenitalis is embedded in dense connective tissue and mesenchyme. Far more dense than in the older embryos and fetuses. Fat is not present.

The development of the bony pelvis is less advanced compared to the older embryos. All the individual bones that constitute the pelvis are outlined in cartilage. The corpus ossis ilii is 
present, but the ala ossis ilii has just started to develop. The reconstruction of the pelvis, shown in Figure $23 \mathrm{~mm} .5$, reveals small developing ala ossis ilii on the left and right side. The corpus ossis pubis on both sides do not reach the midline. The symphysis pubica has not yet been formed. The ramus inferior and superior of the os pubis together with the os ischii surround the foramen obturatum. The tuber ischiadicum and the spina ischiadica are not present.

The os sacrum of the embryos is fully developed in cartilage. Fusion of the vertebrae is not yet present. The connection of the os sacrum to the os coxae is mesenchymal, attaching the pars lateralis of the os sacrum to the os coxae. Ligg. sacroiliaca interossea present in the older fetuses can not be identified as such. The os coccygis is formed in cartilage and shows fusion of the third tot fifth vertebra.

After evaluating the reconstruction of the cartilaginous pelvis of the $23 \mathrm{~mm}$ embryo it is apparent, comparable to the later stages, that the typical angle at the level of the promontorium is not visible. There is even slight inward curving at the level of the promontorium. The os coccygis makes a sharp angle ventrally. Absence of the angle at the level of the promontorium and the sharp angle of the os coccygis seems responsible for the ventral position of the pelvic outlet present in this embryonic stage.

\subsubsection{Musculus obturatorius internus}

The difference in the $\mathrm{m}$. obturatorius developmental stage is striking, compared to the later embryonic and fetal stages.

Running through the sections in a caudal direction the nervus obturatorius appears. It can be seen leaving the pelvic cavity through the foramen obturatum. The point where it pierces the foramen obturatum is well below the lower margin of the ramus inferior ossis pubis, in between the upper and middle third of the foramen. Similar to the later stages it follows the ventral edge of the os ischii, but at a lower level. It runs towards the m. obturatorius externus

At the lateral aspect of the foramen obturatum the $\mathrm{m}$. obturatorius externus is present. It covers the complete inner margins of the foramen and can be followed up to its insertion on the fossa trochanterica femoris. At the pelvic aspect of the foramen there is no appearance of any muscle. The pelvic aspect is covered with connective tissue or mesenchyme. There is no sign of the presence of a membrana obturatoria. At the lower edge of the foramen, at the level of the inner aspect of the ramus ossis ischii, the $\mathrm{m}$. obturatorius internus appears. It covers the pelvic aspect of the ramus ossis ischii. The muscle can be traced leaving the pelvis to insert onto the trochanter major femoris. In this embryo there is muscle tissue all the way up to the insertion. This is in contrast to the later embryos and early fetal stages already described. It is not earlier than the $50 \mathrm{~mm}$ fetus that again the $\mathrm{m}$. obturatorius internus shows muscle fibers all the way up to its insertion on the femur.

In between the medial aspects of both the corpus ossis pubis and the ventral and lateral sides of the allantois a large area of dense tissue is present. In this tissue mesenchymal formations are present that appear to bridge the allantois with the corpus ossis pubis. This mesenchyme is the developing endopelvic fascia and pubovesical ligaments.

At the beginning of the lower two thirds of the foramen obturatum a dense band of tissue arises at the level of the nervus obturatorius. It starts at the level of the acetabulum at the inner aspect of the corpus ossis ischii and stretches out towards the medial aspect of the ramus inferior ossis pubis. It does not reach the surface of the ramus inferior ossis pubis. It ends at the level where the sinus urogenitalis leaves the pelvic cavity. At that point it lies in between the ramus inferior ossis pubis and the sinus urogenitalis, separated by dense tissue. It is connected with the 
developing endopelvic fascia. This band of tissue is mesenchyme of the developing arcus tendineus levatoris ani (ATLA). Following the ATLA through the sections muscles fibers start to appear at its ventral aspect, in between the ramus inferior ossis pubis and the sinus urogenitalis. This is the $\mathrm{m}$. levator ani. At the moment that the $\mathrm{m}$. levator ani appears, the $\mathrm{m}$. obturatorius internus arises at the level of the ramus ossis ischii. This means that at this stage the origin of the $\mathrm{m}$. levator ani is not on the inner surface of the m. obturatorius internus, which was the case in later stages.

\subsubsection{Musculus levator ani}

As it originates it is immediately clear that the $\mathrm{m}$. levator ani is one single muscle.

Comparable to the later stages, the $\mathrm{m}$. levator ani shows a gradual thickening at its ventral side. The ventral margin is surrounded by dense tissue that exists of connective tissue and mesenchyme. As already mentioned earlier, this embedding tissue can be followed towards the ventral and lateral sides of the sinus urogenitalis and further cranial to the ventro-lateral sides of the allantois. In front of the allantois the tissue makes contact with the medial side of the ramus inferior ossis pubis and the allantois itself. So there is a connection, via mesenchyme, of the $\mathrm{m}$. levator ani, the allantois, the sinus urogenitalis and the arcus tendineus levatoris ani. This tissue has to be the future endopelvic fascia, making contact with the ATLA, including the pubovesical ligaments. In this area the urogenital diaphragm will develop.

At its medial side the $\mathrm{m}$. levator ani is separated from the sinus urogenitalis by a broad band of loose connective tissue. There is no direct connection between the two structures. Following this border through the sections it becomes smaller behind the sinus urogenitalis and in front of the hindgut. This separation of the $\mathrm{m}$. levator ani by loose connective tissue is maintained all the way up to the disappearance of the $\mathrm{m}$. levator ani in front of the tip of the os coccygis. So there is no direct connection between the sinus urogenitalis and hindgut and the m. levator ani. Behind the sinus urogenitalis, at the level of the hindgut, the ventral margin of the $\mathrm{m}$. levator ani makes contact with the deep part of the external sphincter. At this stage a separate deep and larger superficial part of the $\mathrm{m}$. sphincter externus can be identified.

At its lateral side the $\mathrm{m}$. levator ani is first covered by connective tissue and mesenchyme that can be followed all the way up to the foramen obturatum. Following the muscle trough the sections the $\mathrm{m}$. obturatorius internus starts to appear at the dorso-lateral side of the $\mathrm{m}$. levator ani. They keep a close relationship near the upper margin of the ramus ossis ischii, but show no direct connection. Passing alongside the ramus ossis ischii the border between the $\mathrm{m}$. levator ani and the $\mathrm{m}$. obturatorius internus increases as the m. obturatorius internus pulls away, leaving the pelvis. The lateral side of the $\mathrm{m}$. levator ani is now covered by the developing structures in the fossa ischiorectalis. Passing the hindgut the $\mathrm{m}$. levator ani is covered on its lateral side by connective tissue and fat of the developing buttocks.

Cranially the dorsal side of the $\mathrm{m}$. levator ani continues into the arcus tendineus levatoris ani. Following the dorsal margin through the embryo the m. obturatorius internus appears. After the disappearance of the $\mathrm{m}$. obturatorius internus the dorsal margin is constituted of loose connective tissue until the $\mathrm{m}$. levator ani disappears in front of the os coccygis. Near the point where the $\mathrm{m}$. obturatorius leaves the pelvis a third muscle appears at the dorsal margin of the corpus ossis ischii. This muscle is the $\mathrm{m}$. coccygeus.

At its most caudal margin, the $\mathrm{m}$. levator ani is lost in dense tissue that can be followed up to the tip of the os coccygis. This tissue is the developing ligamentum anococcygeum as it forms a connection between the dorsal end of the external sphincter (deep part), the $\mathrm{m}$. levator ani (of both sides) and the os coccygis. Figure $23 \mathrm{~mm} .4$ gives a good detail of the levator ani and its relationship 
to the ligamentum anococcygeum.

\subsubsection{Musculus coccygeus}

At the surface of the most dorsal part of the corpus ossis ischii, the m. coccygeus originates. No formation of a future spina ischiadica is present at this stage. The origin of the $m$. coccygeus is at the level where the $\mathrm{m}$. obturatorius internus leaves the pelvis. In adults this point is just below the spina ischiadica. A distinct presence of the ATLA is not noted in the $22 \mathrm{~mm}$ embryo. In the $23 \mathrm{~mm}$ embryo WK 548 the developing ATLA is identified (Figure 23mm.3).

After it originates the m. coccygeus rapidly increases in volume as it progresses towards the os coccygis. At this embryonic stage the $m$. coccygeus already appears to constitute of a dorsal and ventral part. In contrast to the later embryos and fetuses this subdivision is hardly visible. It can be noted by the different orientation by which the muscle fibers are cut. The dorsal part is the future ligamentum sacrospinale and is bigger than the ventral part, being the actual $\mathrm{m}$. coccygeus. At some point in the $\mathrm{m}$. coccygeus of the $23 \mathrm{~mm}$ embryo WK548 the division of the m. coccygeus is better discernable (Figure 23mm.4).

Following the dorsal part of the m. coccygeus through the embryo it is lost in connective tissue that is fixed to the lateral surface of the os sacrum.

The ventral part travels towards the midline and can be followed nearly all the way up to the insertion on the os coccygis. Connection of the $\mathrm{m}$. coccygeus to the os coccygis is made by connective tissue that is far less definable as fascia as it is in the $34 \mathrm{~mm}$ fetus (Figure $34 \mathrm{~mm} .5$ )

\subsubsection{Musculus sacrococcygeus ventralis}

The $\mathrm{m}$. sacrococcygeus ventralis cannot be identified in this embryo.

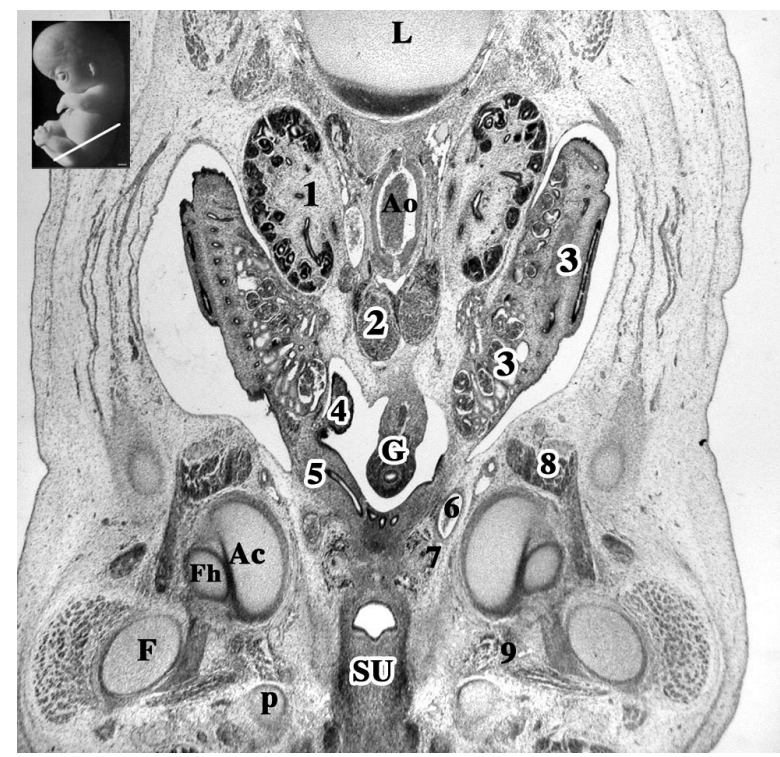

Figure 23mm.1

Insert: level of section indicated by a white line.

Ac, acetabulum; Ao, aorta; F, femur; Fh, caput femoris; G, gut; L, lumbar verte bra; $\mathbf{p}$, os pubis (ramus inferior); $\mathbf{S U}$, sinus urogenitalis; 1, metanephros (kidney); 2 , chromatofin tissue; 3, mesonephros; $\mathbf{4}$, testis; $\mathbf{5}$, mesonephric duct (Wolffian duct); $\mathbf{6}$, arteria umbilicalis; $\mathbf{7}$, ureter; 8 , m. psoas major; $\mathbf{9}, \mathrm{m}$. obturatorius externus. 

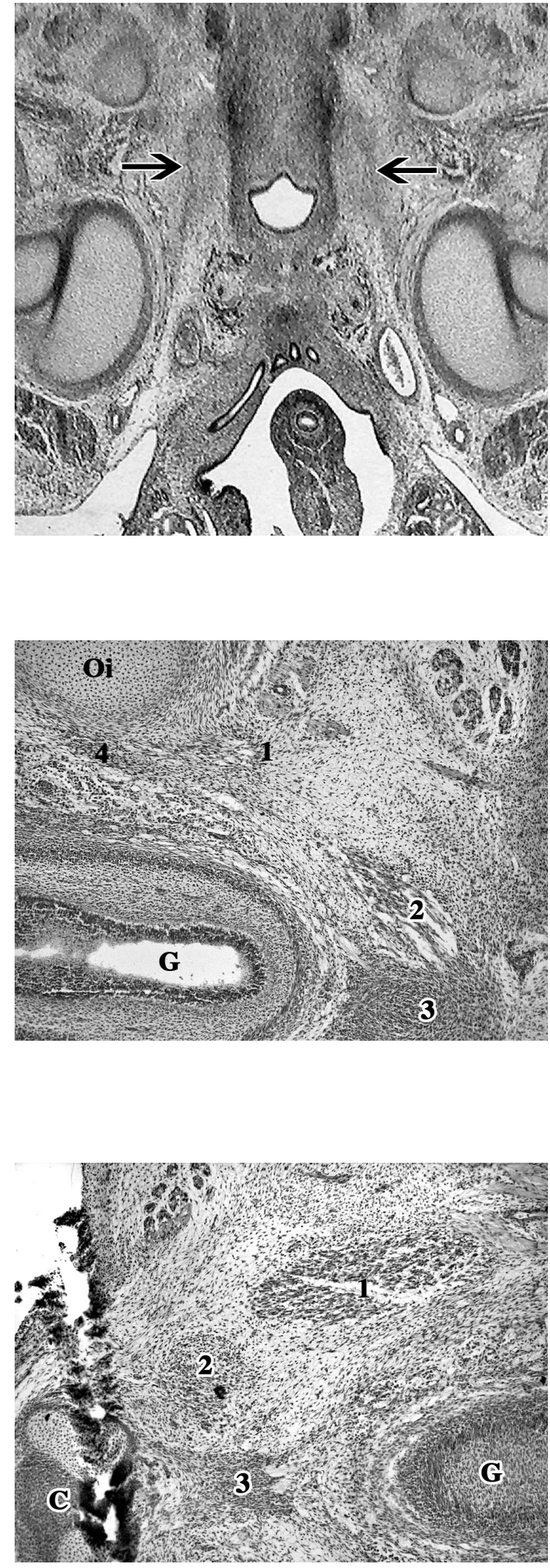

\section{Figure 23mm.2}

Enlarged detail of Figure 23mm.1, but upside down.

The black arrows point towards the arcus tendineus levatoris ani, running from in between the sinus urogenitalis and ramus inferior ossis pubis towards the pelvic aspect of the lower end of the acetabulum. The ATLA can be seen as a dark grey band.

\section{Figure 23mm.3}

Detail of $23 \mathrm{~mm}$ embryo WK548. Left side spinal column.

G, hindgut; Oi, ramus/corpus ossis ischii;

$\mathbf{1}, \mathrm{m}$. coccygeus; $\mathbf{2}, \mathrm{m}$. levator ani; $\mathbf{3}$, deep part of $\mathrm{m}$. sphincter ani externus; $\mathbf{4}$, part of arcus tendineus levatoris ani.

Note the fixation of the $\mathrm{m}$. levator ani to the external anal sphincter.

Figure 23mm.4

Detail of $23 \mathrm{~mm}$ embryo WK548. Black artifact is cutting damage. Left side is ventral.

G, hindgut; $\mathbf{C}$, os coccygis; 1 , m. coccygeus; 2 , m. levator ani; $\mathbf{3}$, ligamentum anococcygeum.

The $\mathrm{m}$. coccygeus is divided in a ventral and dorsal part. The levator ani comes in to close contact with the ligamentum anococcygeum on its way to insert on the lateral side of the os coccygis. 


\subsubsection{D-reconstruction}

Oblique view of the pelvis (Figure

23mm.5)

This overview of the reconstructed pelvis gives a good impression of the degree of development of the pelvis. It is beyond the scope of this thesis to describe the development of the bony pelvis itself. Yet it is interesting to compare the pelvis of this $23 \mathrm{~mm}$ embryo to the pelvis of the $50 \mathrm{~mm}$ fetus (Figure $50 \mathrm{~mm} .9$ ). Note for instance the relatively small volume of the pelvis compared to the spinal column. The ala ossis ilii have started to develop, extending as a small rim to the front. The left and right corpus ossis pubis do not meet in the midline. There is no symphysis pubica. The foramen obturatum is completely formed, but is relatively small. The acetabulum is outlined, but it is not as deep as in the $50 \mathrm{~mm}$ fetus. Especially note the relatively large volume of the os coccygis.

\subsubsection{D-reconstruction}

Oblique view from above on the pelvic diaphragm (Figure 23mm.6)

This picture of the 3D-reconstruction is taken from above, showing the (right) developing pelvic diaphragm from the inside of the pelvis. In the lower right corner is the os sacrum. In the upper left corner the os pubis. The pelvic rim is open in the front. The reconstructed sinus urogenitalis and hindgut have been left out for a better view.

In red the reconstruction of the $\mathrm{m}$. obturatorius internus is shown. Figure $23 \mathrm{~mm} .7$ shows a more detailed overview of the foramen obturatum and the position of the $\mathrm{m}$. obturatorius internus. It now becomes evidently clear that the $\mathrm{m}$. obturatorius internus does not reach the foramen obturatum in this stage of its embryological development. It is situated on the inner side of the ramus and corpus ossis ischii (Figure 23mm.6). It can be seen leaving the pelvis at the dorsal edge of the ramus ossis ischii and at the caudal part of the corpus ossis ischii. In the older embryos and fetuses the $\mathrm{m}$. obturatorius internus extends fur- ther in the direction of the corpus ossis pubis. The dorsal extension and the insertion on the trochanter major femoris is identical to the later stages.

In dark blue the reconstruction of the $\mathrm{m}$. levator ani is shown. It lies in front and does not cover the $\mathrm{m}$. obturatorius internus anywhere. The ventral to dorsal extension does not change in the direction of the os coccygis, except for the last part where it disappears in the ligamentum anococcygeum. The $\mathrm{m}$. levator ani shows the same curving around the sinus urogenitalis as it does in the later stages, caused by the attachment to the deep part of the $m$. sphincter ani externus. The sphincter is not reconstructed. The position of the $\mathrm{m}$. levator ani relative to the os pubis is different compared to the later stages. The ventral margin of the levator ani is further away from the os pubis. The gap is filled by connective tissue and mesenchyme forming the endopelvic fascia and part of the diaphragma urogenitalis. The most cranial margin of the $\mathrm{m}$. levator ani is smaller. This cranial margin is in fact the ATLA, that is not followed as much dorsally as it does in the older embryos and fetuses. The levator ani closes a smaller part of the ventral quadrant of the pelvic outlet compared to the $28 \mathrm{~mm}$ embryo.

The $\mathrm{m}$. coccygeus is reconstructed in green. Its origin is at the level of the future spina ischiadica and its insertion is on the surface of the last sacral and first coccygeal vertebrae. It has roughly the same shape compared to the 28 $\mathrm{mm}$ embryo and $34 \mathrm{~mm}$ fetus. The reconstruction shows how the cranial part of the $m$. coccygeus extends dorsally towards the os sacrum. This is the part of the $m$. coccygeus that will become the ligamentum sacrospinale. The ventral to dorsal extension of the $\mathrm{m}$. coccygeus becomes much smaller towards the os coccygis. It actually shows that the development of the $\mathrm{m}$. coccygeus is less advanced, especially in the ventral direction towards the $\mathrm{m}$. levator ani. The border between the $\mathrm{m}$. levator ani and $\mathrm{m}$. coccygeus is broader. The $\mathrm{m}$. coccygeus closes a smaller part of the dorsal 
quadrant of the pelvic outlet than it does in the 28 mm embryo.

\subsubsection{D-reconstruction}

Frontal (Figure 23mm.8) and caudal

(Figure 23mm.9) view of the pelvic diaphragm

Figure $23 \mathrm{~mm} .8$ shows a complete frontal picture of the reconstruction. Like in the older embryos and fetuses the pelvic outlet is projected in a frontal plain. The sharp angle of the os coccygis to the os sacrum is less striking than it is in the $28 \mathrm{~mm}$ embryo, but comparable to the $34 \mathrm{~mm}$ fetus.

The $\mathrm{m}$. obturatorius internus is reconstructed in red. Note the position of the muscle on the pelvic surface of the ramus and corpus ossis ischii (Figure 23mm.9), extending less cranially compared to the $28 \mathrm{~mm}$ fetus.

In dark blue the reconstruction of the $\mathrm{m}$. levator ani. It runs from the lower margin of the upper part of the ramus inferior ossis pubis towards the os coccygis. The upper margin of the levator ani is therefore lower than in the $28 \mathrm{~mm}$ embryo, where it extends towards the lower part of the corpus ossis pubis. Also note that the $\mathrm{m}$. levator ani extends further cranial than the $\mathrm{m}$. obturatorius internus (Figure 23mm.9), whereas in the $28 \mathrm{~mm}$ embryo the $\mathrm{m}$. obturatorius internus extends further. The left and right $m$. levator ani surround the corpus pelvinum, which is reconstructed in yellow. Both the left and the right $\mathrm{m}$. levator ani are separate muscles and have a single curve around the corpus pelvinum. In the $28 \mathrm{~mm}$ embryo there was a second curving behind the rectum (hindgut) and in later stages also between the sinus urogenitalis and the rectum. In between the hindgut and the os coccygis the left and right levator ani curve towards the midline, reaching the developing ligamentum anococcygeum. The distance between the hindgut and the os coccygis is bigger than in the $28 \mathrm{~mm}$, but comparable to the 34 $\mathrm{mm}$ fetus. Closure of the pelvic diaphragm in the midline is not present. Compared to the $28 \mathrm{~mm}$ embryo, closure of the pelvic diaphragm in the midline is less advanced in this $23 \mathrm{~mm}$ embryo. The insertion of the $\mathrm{m}$. levator ani onto the surface of the os coccygis is also not yet completed. A small gap, but bigger than in the $28 \mathrm{~mm}$ embryo, is still present and is formed by connective tissue that is not reconstructed.

The $\mathrm{m}$. coccygeus is reconstructed in green. It appears to be as thick as the m. levator ani. Its total volume is less than in the $28 \mathrm{~mm}$ embryo. In contrast to the older stages the position of the $m$. coccygeus is in the same direction as the $\mathrm{m}$. levator ani. In the older stages the $\mathrm{m}$. coccygeus is situated more oblique with its dorsal part more lateral. This is due to the fact that the os sacrum in this $23 \mathrm{~mm}$ embryo is smaller. Growing in size makes the dorsal part of the $m$. coccygeus extend more lateral. The $\mathrm{m}$. coccygeus in total is situated lateral from the $\mathrm{m}$. levator ani, which is comparable to the later stages.

Figure $23 \mathrm{~mm} .9$ suggests that the pelvic diaphragm consists of four quadrants, as it does in the older embryos and fetuses. The ventral left and ventral right quadrants are filled by the left and right $\mathrm{m}$. levator ani and the dorsal quadrants by the $\mathrm{m}$. coccygeus respectively. The $\mathrm{m}$. coccygeus again appears smaller than in the $28 \mathrm{~mm}$ embryo. It does not fill the dorsal quadrants as much as it does in the later stages. 
full color illustrations of the photos on this page can be found on page 121-123

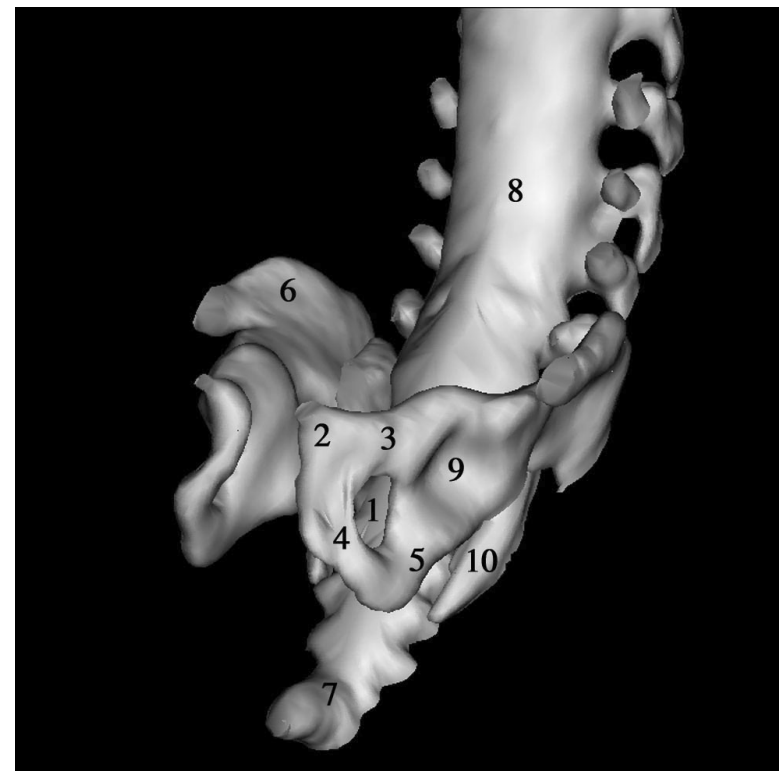

\section{Figure 23mm.5}

Oblique view of the reconstructed pelvis.

$\mathbf{1}$, foramen obturatum; $\mathbf{2}$, corpus ossis pubis; $\mathbf{3}$, ramus superior ossis pubis; $\mathbf{4}$, ramus inferior ossis pubis; $\mathbf{5}$, ramus ossis ischii/corpus ossis ischii; $\mathbf{6}$, developing ala ossis ilii; $\mathbf{7}$, os coccygis; $\mathbf{8}$, spinal column; $\mathbf{9}$, acetabulum; 10, lateral margin of os sacrum.

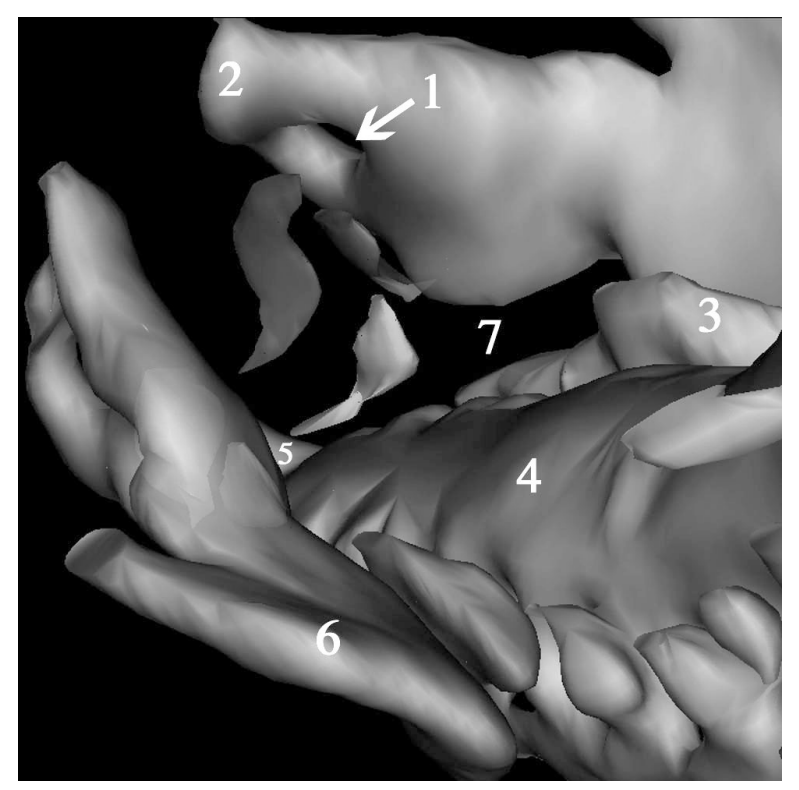

Figure 23 mm.6

View from above on the pelvic diaphragm.

$\mathbf{1}$, foramen obturatum; $\mathbf{2}$, corpus ossis pubis; $\mathbf{3}$, pars lateralis os sacrum; $\mathbf{4}$, os sacrum; $\mathbf{5}$, os coccygis; $\mathbf{6}$, ala ossis ilii; red, m. obturatorius internus; blue, $m$. levator ani; green, $m$. coccygeus. 


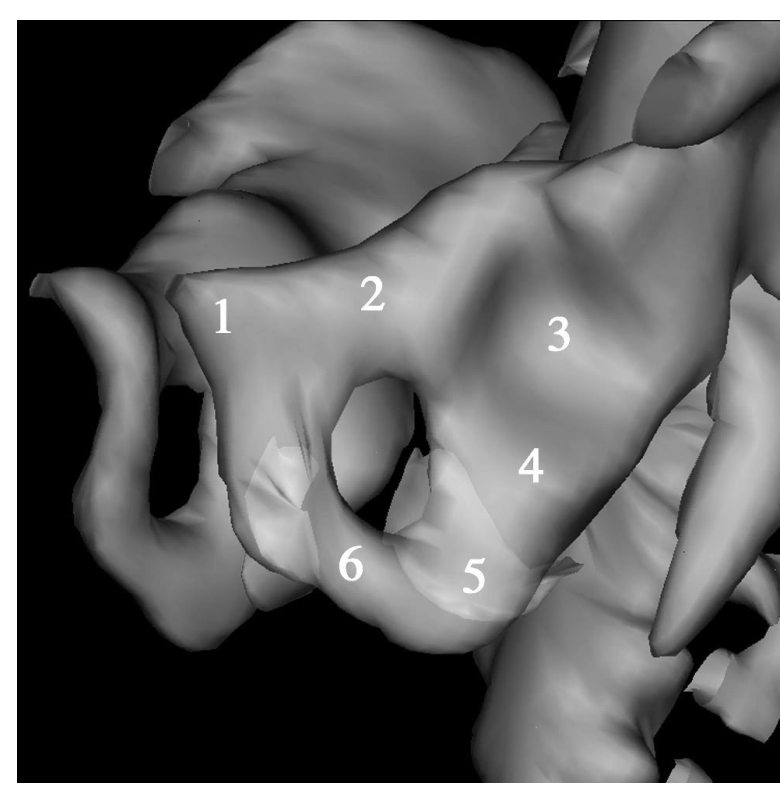

Figure $23 \mathrm{~mm} .7$

Close view of the left foramen obturatum.

$\mathbf{1}$, corpus ossis pubis; $\mathbf{2}$, ramus superior ossis pubis; $\mathbf{3}$, acetabulum; $\mathbf{4}$, corpus ossis ischii; $\mathbf{5}$, ramus ossis ischii; $\mathbf{6}$, ramus inferior ossis pubis; red, m. obturatorius internus.

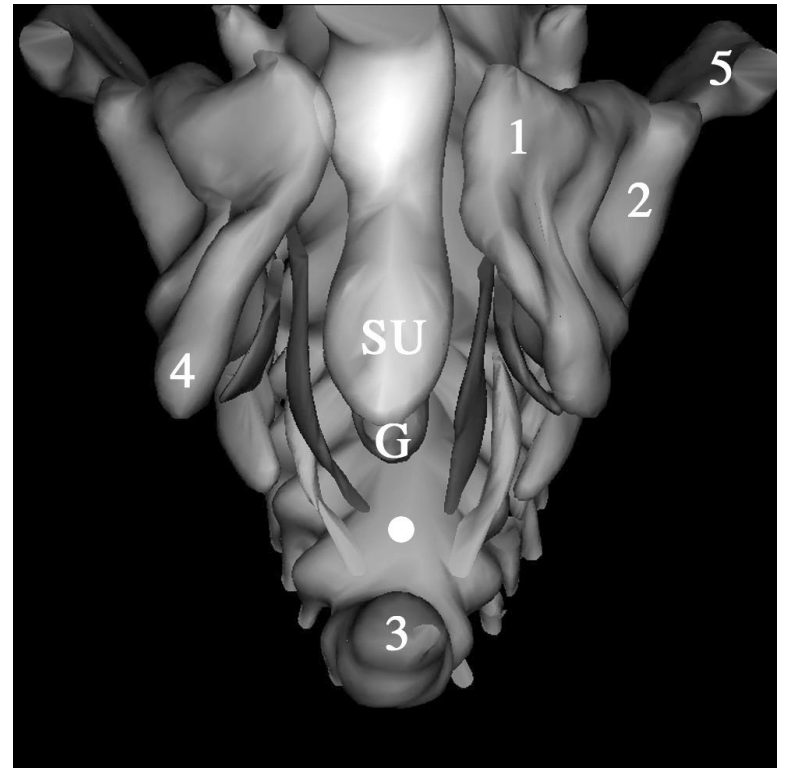

Figure 23mm.8

Frontal view of the pelvic diaphragm.

$\mathbf{G}$, hindgut; $\mathbf{S U}$, sinus urogenitalis; $\mathbf{1}$, corpus ossis pubis; $\mathbf{2}$, acetabulum; $\mathbf{3}$, os coccygis; $\mathbf{4}$, ramus ossis ischii; $\mathbf{5}$, ala ossis ilii; white dot, future ligamentum anococcygeum; red, $\mathrm{m}$. obturatorius internus; blue, $m$. levator ani; green, m. coccygeus.

.

Figure 23 mm.9

View of the pelvic diaphragm from below.

G, hindgut; SU, sinus urogenitalis; $\mathbf{1}$, acetabulum; $\mathbf{2}$, ramus ossis ischii at level of developing spina ischiadica; $\mathbf{3}$, os coccygis; $\mathbf{4}$, os sacrum; $\mathbf{5}$, os ilium (ala ossis ilii); $\mathbf{6}$, ramus inferior ossis pubis; red, m. obturatorius internus; blue, m. levator ani; green, m. coccygeus. 


\subsection{Stage 20}

\section{0 mm (WK7996, WK7262, WK7993, WK1423) and $21 \mathrm{~mm}$ (WK2287, WK8071) \pm 52 days}

\subsubsection{General features}

These embryos with a CRL of $20 \mathrm{~mm}$ and $21 \mathrm{~mm}$ respectively are about 7.5 weeks (53-54 days) post conception. The embryos are in developmental stage 20 according to the subdivision by Streeter. The embryos are cut transverse in $10 \mu \mathrm{m}$ sections and stained with HE (see Table 2). To make the description of stage 20 readable only the $20 \mathrm{~mm}$ embryo WK7262 is described. The other embryos are in essence the same. If necessary the other stage 20 embryos will be discussed separately.

Figure $20 \mathrm{~mm} .1$ shows a section through the $20 \mathrm{~mm}$ embryo WK7993. Although this particular embryo is slightly macerated, it still gives a nice overview of the developing pelvis. Studying the sections through the mesonephros the embryo appears to be male. The section shown in Figure $20 \mathrm{~mm} .1$ is a section well below the level of the mesonephros and metanephros. The section is slightly oblique. Since the pelvic outlet in this stage of development is pointed in a forward direction (comparable to all the later stages), the dorsal end of the section is cut through the lower lumbar spinal column and the ventral end through the level of the acetabulum.

The mesenchyme is more concentrated than in the $23 \mathrm{~mm}$ embryo. It is more compact and shows a lower level of development. There is hardly any connective tissue present for example. From behind the hindgut and radiating around it, the mesothelium of the sinus urogenitalis is visible containing the paramesonephric and mesonephric ducts as well as small blood vessels. Also note the relatively large volume of the nervus obturatorius, which can be followed from the vertebral column to the $\mathrm{m}$. obturatorius externus. It can be seen leaving the pelvis, curving around the cor- pus ossis ischii.

The pelvis shows a lesser development compared to the $23 \mathrm{~mm}$ embryo. The separately developing corpus ossis pubis, corpus ossis ischii and corpus ossis ilii are visible. The ala ossis ilii shows a similar development as in the stage 21 embryos. Compared to the $23 \mathrm{~mm}$ embryo especially the ramus inferior ossis pubis is less developed. It does not show a cartilaginous pattern yet, but is outlined in clustered mesenchymal cells. The foramen obturatum is therefore just present, not completely surrounded by cartilage. The ramus superior ossis pubis is outlined in cartilage. Like the $23 \mathrm{~mm}$ embryo the left and right os pubis have not reached the midline.

The development of the os sacrum is comparable to stage 21 . It is completely outlined in cartilage. The connection of the pars lateralis of the os sacrum to the os ilium is made by mesenchyme. The os coccygis is present, but is not distinguishable from the os sacrum, other than being the last vertebrae of the spinal colomn. The presence of fusion of the last vertebrae cannot be concluded from the available material.

No reconstruction has been made of the pelvis and pelvic diaphragm. The development of the pelvic diaphragm will be discussed and illustrated with photographs. A reconstruction of the developmental stage of the separate muscles appeared to have no extra value over the reconstructions of the $23 \mathrm{~mm}$ embryo. This will become clear after the description of these $20 \mathrm{~mm}$ embryos.

\subsubsection{Musculus obturatorius internus}

Running through the sections in a caudal direction the nervus obturatorius appears. It can be seen leaving the pelvic cavity through the foramen obturatum. The point where it pierces the foramen obturatum is well below the lower margin of the ramus inferior ossis pubis, somewhere between the upper and middle third of the foramen. Similar to the later stages it follows the ventral edge of the 
os ischii, but at a lower level. It runs towards the $\mathrm{m}$. obturatorius externus. Since the development of the os pubis is less advanced, it can now be concluded that the localization of the nervus obturatorius at a lower level is caused by a smaller ramus superior ossis pubis. The nervus obturatorius seems to have a fixed position and the ramus superior ossis pubis will displace itself towards the nerve. Figure $20 \mathrm{~mm} .2$ shows a photograph of the $20 \mathrm{~mm}$ embryo WK7262 at the upper level of the foramen obturatum. In this embryo the ramus inferior ossis pubis shows a cartilaginous pattern. The development of cartilage in the ramus inferior ossis pubis thus shows some variation in stage 20 embryos. Presumably the embryonic stage 20 is the stage where chondrofication of the ramus inferior begins.

At the lateral aspect of the foramen obturatum the $\mathrm{m}$. obturatorius externus is present. It covers the complete inner margins of the foramen and can be followed up to its insertion on the fossa trochanterica femoris. The pelvic aspect of the foramen obturatum is covered with mesenchyme. There is no sign of presence of a membrana obturatoria. At the lower edge of the foramen, at the level of the inner aspect of the ramus ossis ischii, the m. obturatorius internus appears (Figure $20 \mathrm{~mm} .3$ ). It covers the pelvic aspect of the ramus ossis ischii, comparable to the 23 $\mathrm{mm}$ embryos. The muscle can be traced leaving the pelvis to insert on the trochanter major femoris (Figure $20 \mathrm{~mm} .4$ ). The $\mathrm{m}$. obturatorius internus shows muscle fibers all the way up to its insertion onto the trochanter major femoris.

In contrast to embryonic stage 21 no clear arcus tendineus levatoris ani can be identified. In Figure $20 \mathrm{~mm} .3$ some sign of development of the levator ani fascia is present, as a dense band of mesenchyme that can be followed from the $\mathrm{m}$. levator ani, over the m. obturatorius internus, towards the dorsal margin of the corpus ossis ischii. This figure also shows that the $\mathrm{m}$. obturatorius lies dorsolateral from the $\mathrm{m}$. levator ani. Similar to the
$23 \mathrm{~mm}$ embryos the $\mathrm{m}$. levator ani does not cover the $\mathrm{m}$. obturatorius internus.

In these $20 \mathrm{~mm}$ and $21 \mathrm{~mm}$ embryos no sign of a developing endopelvic fascia can be found. Nor is there any sign of developing pubovesical ligaments.

\subsubsection{Musculus levator ani}

As the muscle originates it is immediately clear that the $\mathrm{m}$. levator ani is one single muscle.

Comparable to the later stages, the $\mathrm{m}$. levator ani shows a gradual thickening at its ventral side following it through the sections. The ventral margin is surrounded by mesenchyme, making close contact with the sinus urogenitalis (Figure $20 \mathrm{~mm}$.3). It is in this stage not possible anymore to tell wether this mesenchyme is developing endopelvic fascia or part of the developing diaphragma urogenitalis.

At its medial side the $\mathrm{m}$. levator ani is separated from the sinus urogenitalis by a broad band of loose tissue containing blood vessels. There is no direct connection between the two structures. Following this border through the sections it becomes smaller behind the sinus urogenitalis and in front of the hindgut. This separation of the $\mathrm{m}$. levator ani and the content of the corpus pelvinum is maintained all the way up to the disappearance of the $\mathrm{m}$. levator ani in front of the tip of the os coccygis. So there is no direct connection between the sinus urogenitalis, the hindgut and the $\mathrm{m}$. levator ani. Behind the sinus urogenitalis, at the level of the hindgut, the ventral margin of the $\mathrm{m}$. levator ani makes contact with the deep part of the external sphincter. At this stage a separate deep and larger superficial part of the m. sphincter externus can be identified (Figure 20mm.5).

At its lateral side the $\mathrm{m}$. levator ani is first covered by connective tissue and mesenchyme that can be followed all the way up to the foramen obturatum. Following the muscle trough the sections the m. obturatorius internus starts to appear 
at the dorso-lateral side of the $\mathrm{m}$. levator ani (Figure 20mm.3). They keep a close relationship near the upper margin of the ramus ossis ischii, but show no direct connection. Passing alongside the ramus ossis ischii the border between the $\mathrm{m}$. levator ani and the $\mathrm{m}$. obturatorius internus increases as the $\mathrm{m}$. obturatorius internus pulls away, leaving the pelvis (Figure 20mm.4). The lateral side of the $\mathrm{m}$. levator ani is now formed by the developing fossa ischiorectalis. These structural relations are comparable to the embryonic stage 21 .

Behind the hindgut the $\mathrm{m}$. levator ani travels towards the os coccygis. The connection with the $\mathrm{m}$. sphincter ani externus is lost, as the sphincter disappears. The $\mathrm{m}$. levator ani ends in the developing ligamentum anococcygeum. At this point both the left and the right $\mathrm{m}$. levator ani reach the midline, without making direct contact. The ligamentum anococcygeum is the intermediate between the left and right $\mathrm{m}$. levator ani. This ligament can be traced in these embryos, linking the deep part of the $\mathrm{m}$. sphincter ani externus and the $\mathrm{m}$. levator ani with the os coccygis (Figure 20mm.6).

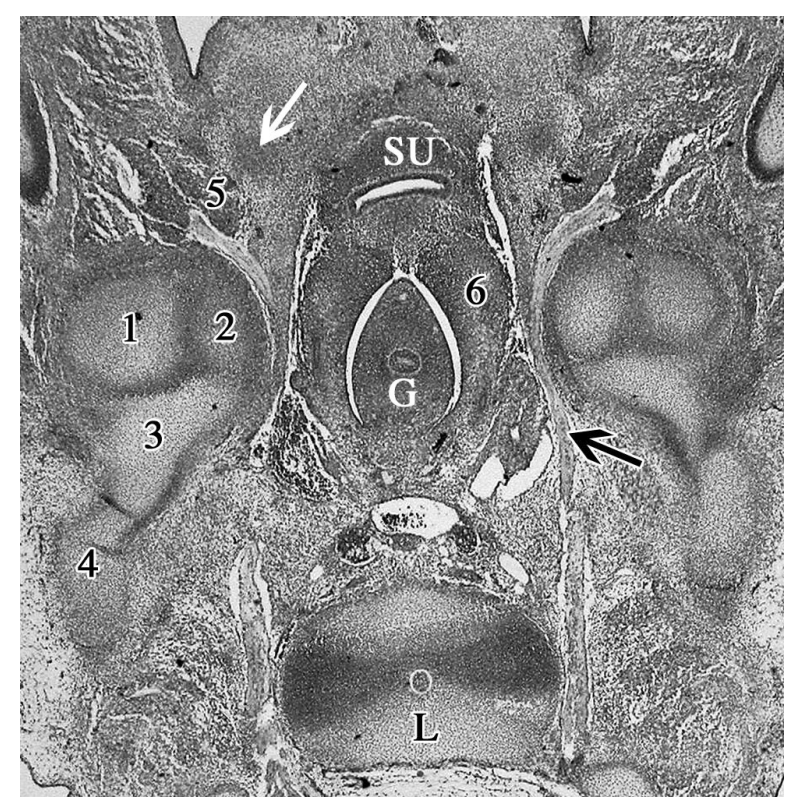

Figure 20mm.1

G, hindgut; L, lumbar vertebra; SU, sinus urogenitalis; white arrow, ramus inferior ossis pubis; black arrow, nervus obturatorius; $\mathbf{1}$, caput femoris; $\mathbf{2}$, corpus ossis ischii; $\mathbf{3}$, corpus ossis ilii; $\mathbf{4}$, ala ossis ilii; $\mathbf{5}, \mathbf{m}$. obturatorius externus; $\mathbf{6}$, embryonic mesothelium.

\subsubsection{Musculus coccygeus}

At the surface of the most dorsal part of the corpus ossis ischii, just above the point where the $\mathrm{m}$. obturatorius internus leaves the pelvis, the $\mathrm{m}$. coccygeus appears. At its point of origin no sign of a developing spina ischiadica can be noted, nor can the arcus tendineus levatoris ani be identified in this region.

Following the $\mathrm{m}$. coccygeus towards the os coccygis its volume increases but in a lesser extent compared to the older embryos. A subdivision in a ventral and dorsal part is present, although it is difficult to delineate the separate parts. The subdivision becomes evidently clear when the $\mathrm{m}$. coccygeus is pierced by a nerve (Figure 20mm.5). Below this level the subdivision of the $\mathrm{m}$. coccygeus is better outlined (Figure $20 \mathrm{~mm}$.6). The dorsal part of the $\mathrm{m}$. coccygeus travels towards the os sacrum and will form the ligamentum sacrospinale. The ventral part, or actual $m$. coccygeus, can be followed through the embryo in the direction of the os coccygis. It is lost in mesenchyme that reaches the surface of the os coccygis.

\subsubsection{Musculus sacrococcygeus ventralis}

The $\mathrm{m}$. sacrococcygeus ventralis cannot be identified in this embryo.

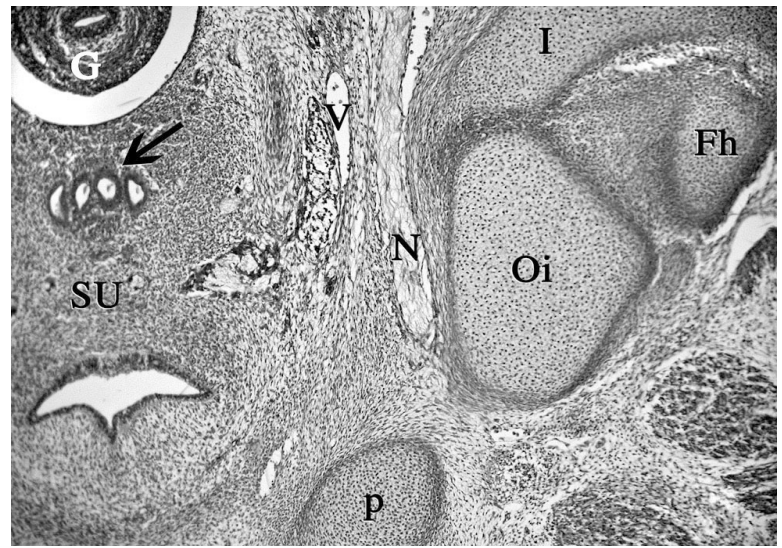

Figure 20mm.2

Fh, caput femoris; G, hindgut; I, corpus ossis ilii; N, nervus obturatorius; $\mathbf{O i}$, corpus ossis ischii; $\mathbf{p}$, ramus inferior ossis pubis; $\mathbf{S U}$, sinus urogenitalis; $\mathbf{V}$, a/v obturatoria; black arrow, mesonephric and paramesonephric ducts. 

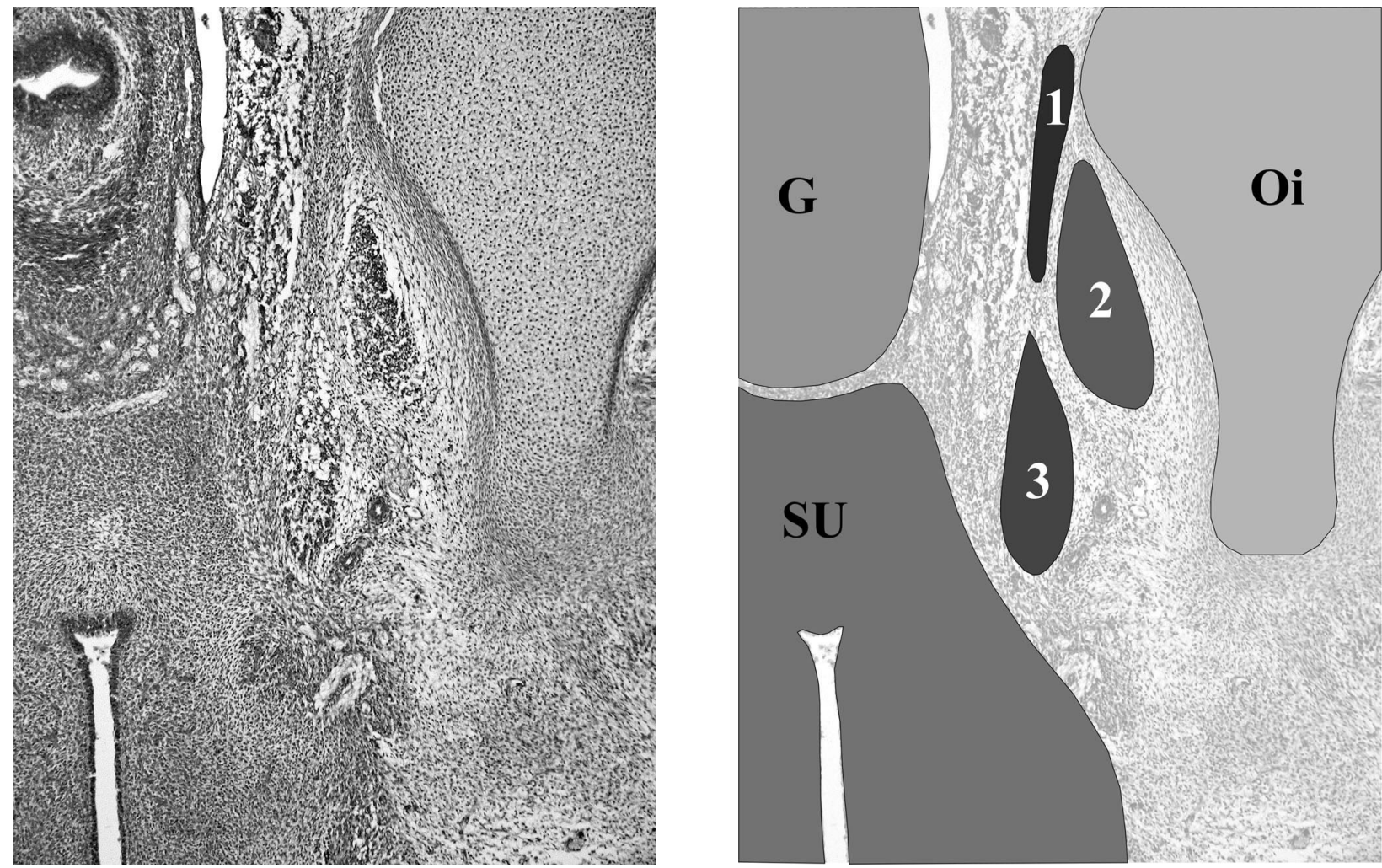

Fig. 20mm.3

G, hindgut; $\mathbf{O i}$, corpus ossis ischii; $\mathbf{S U}$, sinus urogenitalis; $\mathbf{1}$, developing fascia of the $\mathrm{m}$. levator ani; $\mathbf{2}, \mathrm{m}$. obturatorius internus; $\mathbf{3}, \mathrm{m}$. levator ani. A dense band of mesenchyme can be followed from the $\mathrm{m}$. levator ani, over the m. obturatorius internus, towards the dorsal margin of the corpus ossis ischii. This is the developing fascia of the $\mathrm{m}$. levator ani. It runs towards the future ATLA at the medio-dorsal surface of the corpus ossis ischii (at level of the number 1). A little below this level the m. coccygeus will appear.
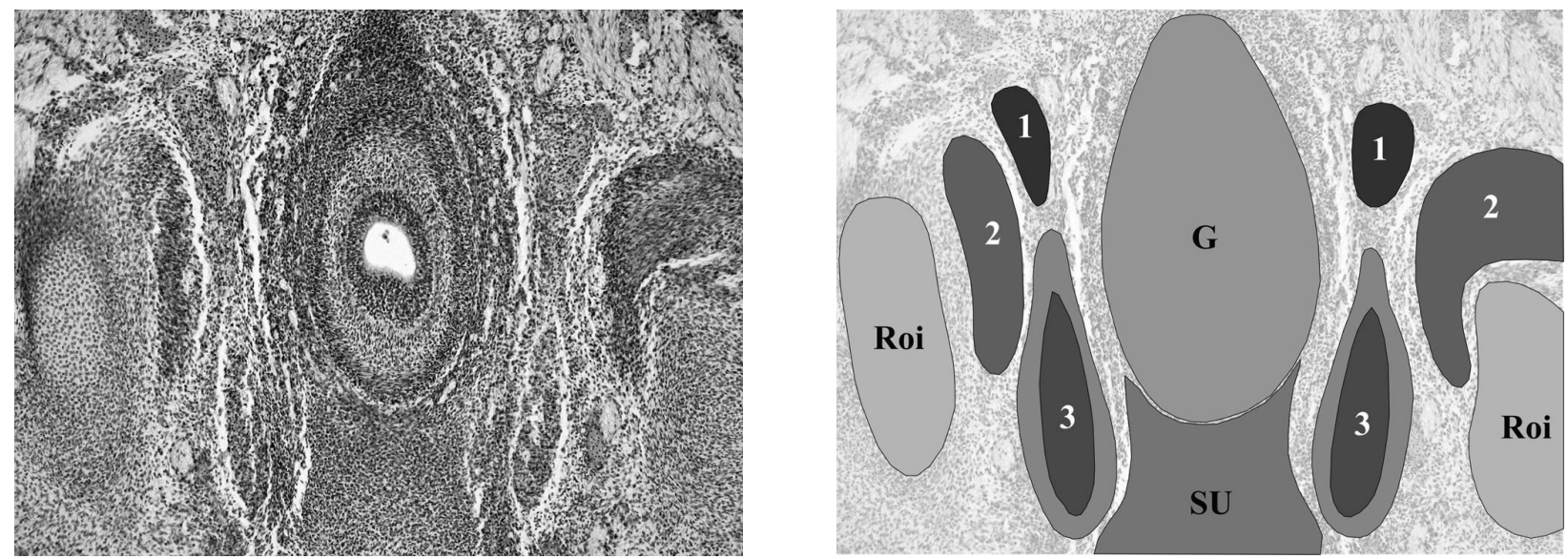

\section{Figure 20mm.4}

G, hindgut; Roi, ramus ossis ischii; SU, sinus urogenitalis; 1, m. coccygeus; $\mathbf{2}$, m. obturatorius internus; $\mathbf{3}$, m. levator ani.

The m. obturatorius internus on the embryos right side curves around the dorsal margin of the corpus ossis ischii to insert on the trochanter major femoris. Note that a thick layer of mesenchyme, developing fascia, covers the m. levator ani. 

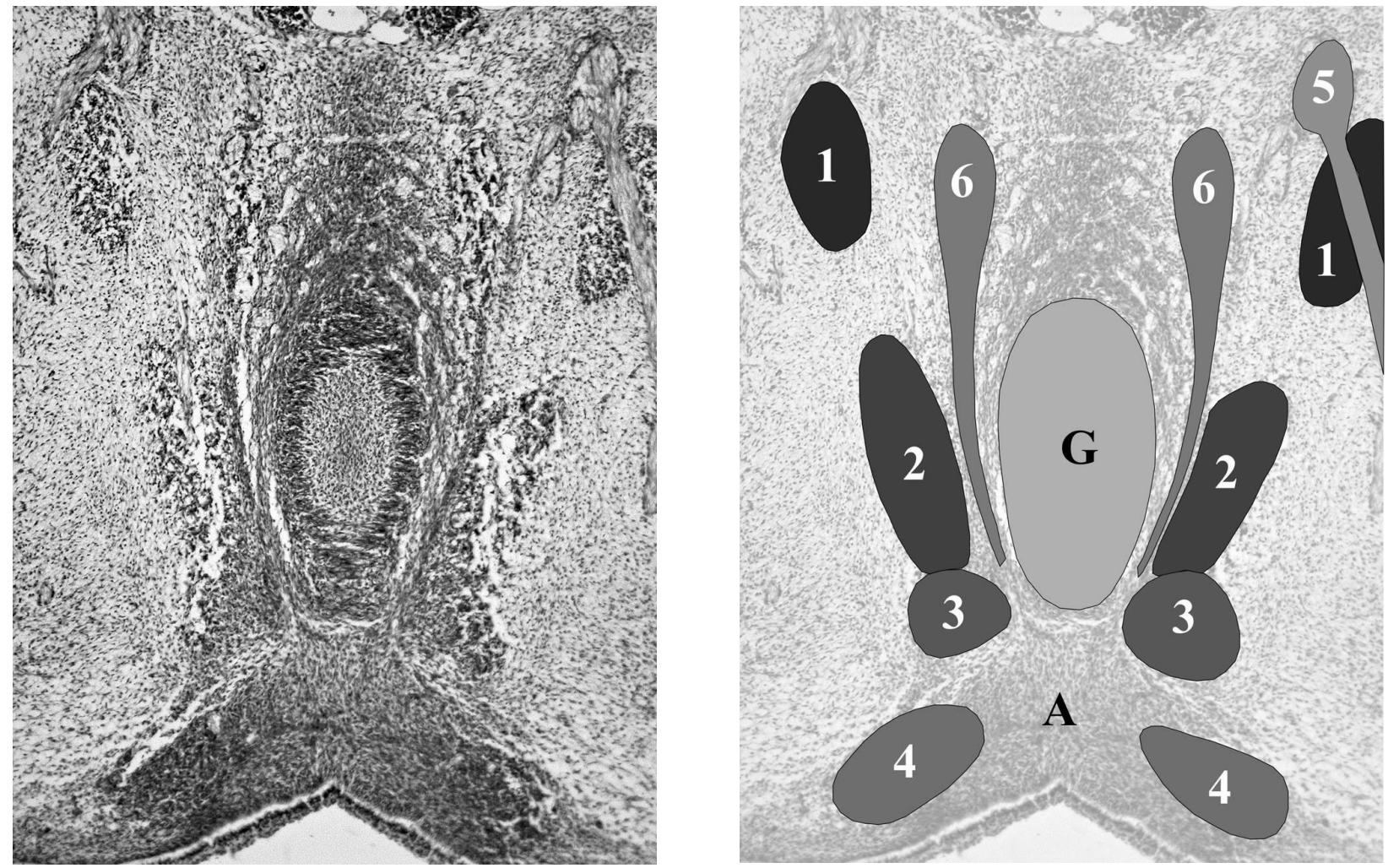

Figure 20mm.5

A, anal membrane; $\mathbf{G}$, hindgut; $\mathbf{1}, \mathrm{m}$. coccygeus; $\mathbf{2}, \mathrm{m}$. levator ani; $\mathbf{3}$, deep part of $\mathrm{m}$. sphincter ani externus; $\mathbf{4}$, superficial part of $\mathrm{m}$. sphincter ani externus; $\mathbf{5}$, branch of nervus pudendus; $\mathbf{6}$, longitudinal muscle layer rectum.

The lower end of the picture is the ventral side of the embryo. The anal membrane is visible in between the superficial part of the external anal sphincter. The $\mathrm{m}$. levator ani is attached to the deep part of the external anal sphincter. The $\mathrm{m}$. coccygeus on the left side is divided in a ventral and dorsal part by a branch of the nervus pudendus.
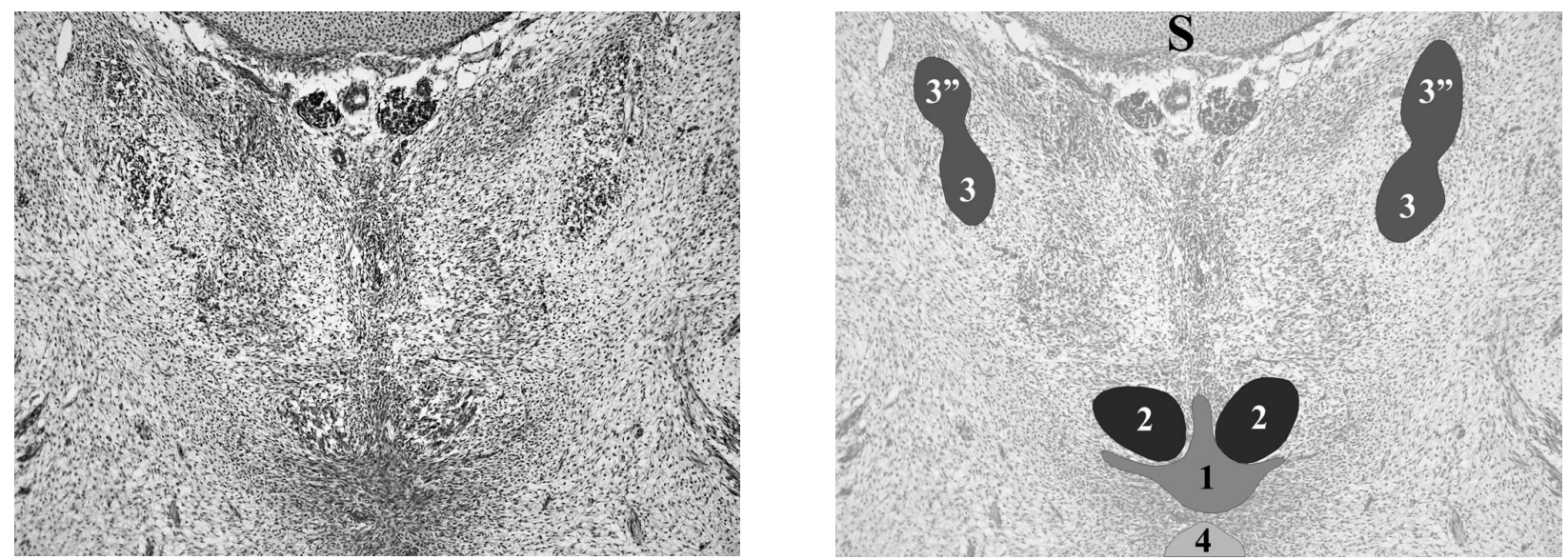

Figure 20mm.6

S, os sacrum; 1, ligamentum anococcygeum; 2, m. levator ani; 3, m. coccygeus; 3", dorsal part of m. coccygeus (ligamentum sacrospinale); 4 , anal seam. 


\subsection{Stage 18-19}

\section{7 mm (WK359, WK4132, WK5032, WK7435) \pm 49 days}

\subsubsection{General features}

These embryos with a CRL of $17 \mathrm{~mm}$ are about 7 weeks post conception. They are in developmental stage 18 according to Streeter. The embryos are cut transverse and stained with HE (see Table 2).

In this stage we were not able to determine the sex type of the embryos by studying the mesonephros and paramesonephros. This is in accordance with embryological textbooks, which indicate that it is not possible to determine the sex type of embryos up to $17 \mathrm{~mm}$ CRL on the basis of the gonads [Hamilton, 1962]. Therefore we looked in the embryos for the presence of the sex chromatin (Barr test) as described earlier. No sex chromatin was present in all the four embryos. So all the embryos are considered male. This could well be a coincidence or a false negative result of the Barr test. Yet, from the earlier described embryos it is already clear that the pelvic diaphragm develops independent from the sinus urogenitalis and therefore independent of its sex type.

The development of the pelvis is less advanced compared to the $20 \mathrm{~mm}$ embryos. The corpus ossis pubis, corpus ossis ischii and corpus ossis ilii are present but their volume is considerably less. A thick layer of mesenchyme, that is already outlining the volume reached in the 20 $\mathrm{mm}$ embryos, surrounds them all. The ramus inferior ossis pubis is not present in cartilage, but as clustered chondroficating cells (Figure 17mm.1). Left and right os pubis do not reach the midline.

A distinct feature of the stage $18 \mathrm{em}$ bryos is the apparent lack of histological differentiation of the pelvic content. The pelvis seems to be completely filled with dense and compact mesenchyme. The hindgut and the sinus urogenitalis are well outlined and recognizable as well as the nerves and blood vessels. All the interposing tissue is however diffusely arranged and shows clustering or condensation as a sign of the development of other different anatomical pelvic components, like muscles. At this stage of embryonic development it becomes difficult to denominate the different components around the corpus pelvinum. Exclusion of possibilities and knowledge of the form and position of the muscles in the older embryos and fetuses make identification of the muscles of the pelvic diaphragm possible.

In the embryo WK7435 no histological clustering of cells was visible in the area of the pelvic diaphragm muscles. This could mean that the histological development of the pelvic diaphragm begins at about embryonic stage 18 .

\subsubsection{Musculus obturatorius internus}

The $\mathrm{m}$. obturatorius externus is present on the lateral side of the foramen obturatum. It attaches to the inner margin of the developing ramus inferior ossis pubis as is illustrated in Figure $17 \mathrm{~mm}$.1. The membrana obturatoria has not developed yet. A broad band of mesenchyme fills the pelvic aspect of the foramen obturatum. The $\mathrm{m}$. obturatorius internus is not present at the level of the foramen obturatum.

At the inner level of the ramus ossis ischii and corpus ossis ischii the m. obturatorius internus is visible (Figure $17 \mathrm{~mm} .2$ ). A large border of developing fascia surrounds it. The muscle's mesenchyme can be seen leaving the pelvis around the dorsal edge of the corpus ossis ischii (Figure 17mm.4). The muscle shows little striation as a sign of early development.

When it appears, the $\mathrm{m}$. obturatorius internus is covered on its medial side by the developing fascia of the m. levator ani. This developing fascia can be recognized as a dense strand of clustered cells running from the $\mathrm{m}$. levator ani towards the corpus ossis ischii, covering the $\mathrm{m}$. obturatorius internus. The $\mathrm{m}$. levator ani itself lies in front of the $\mathrm{m}$. obturatorius internus (Figure $17 \mathrm{~mm} .2$ ). Following the $\mathrm{m}$. obturatorius internus 
through the embryo, it turns away laterally to eventually leave the pelvis. As the m. obturatorius internus pulls away, the fossa ischiorectalis is present (Figure 17mm.3).

\subsubsection{Musculus levator ani}

At the lower level of the foramen obturatum, in between the sinus urogenitalis and the mesenchymal thickening of the developing membrana obturatoria a dense clustering of cells appears (Figure $17 \mathrm{~mm} .1$ ). Its ventral margin lies well away from the ramus inferior ossis pubis in a dorso-medial direction. The dorsal margin of the clustered cell group points towards the os ischium. Following it through the embryo it is undoubtfully the developing $\mathrm{m}$. levator ani.

Like in the $20 \mathrm{~mm}$ embryos, the ventral margin is embedded in undifferentiating mesenchyme that surrounds the sinus urogenitalis laterally and ventrally. At this level near the os pubis and lower edge of the foramen obturatum the clustered cells do not yet have the histological appearance of muscle cells. With the foreknowledge of it being the $\mathrm{m}$. levator ani, a developing muscle and fascial part is recognized.

The lateral side of the $\mathrm{m}$. levator ani is first covered by mesenchyme running towards the foramen obturatum. A border of numerous small blood vessels and mesenchyme, separating the muscle from the sinus urogenitalis, covers the medial side.

At the level of the ramus ossis ischii the $\mathrm{m}$. obturatorius internus appears, dorso-lateral from the $\mathrm{m}$. levator ani (Figure $17 \mathrm{~mm} .2$ ). At this point the $\mathrm{m}$. levator ani lies beside the hindgut. Remarkable is that at this level the $\mathrm{m}$. levator ani shows more histological features of muscle cells, i.e. striation. The ventral to dorsal extension of the muscle itself is small. It is extended dorsally by the already mentioned strand of cells forming the developing fascia of the $\mathrm{m}$. levator ani, overlying the $\mathrm{m}$. obturatorius internus (Figure $17 \mathrm{~mm} .3$ ).

Following the $\mathrm{m}$. levator ani further in the direction of the os coccygis, the muscle shows more differentiation as the anal sphincter complex is approached. The ventral margin of the $\mathrm{m}$. levator ani is lost in the deep part of the $\mathrm{m}$. sphincter ani externus. This means that the $\mathrm{m}$. levator ani is connected to and has a close relation with the deep external anal sphincter. At this embryonic stage a clear separation between a superficial and deep part can already be made (Figure 17mm.4). The lateral aspect of the $\mathrm{m}$. levator ani borders the fossa ischiorectalis. Medially the $\mathrm{m}$. levator ani is separated from the hindgut by mesenchyme.

Passing behind the hindgut attachment of the $\mathrm{m}$. levator ani to the anal sphincter complex is lost (Figure 17mm.5). The ventral margin of the levator ani is formed by loose mesenchyme between the anal membrane and the muscle. On its lateral side is tissue of the developing buttocks. Medially the m. levator ani becomes attached to the developing ligamentum anococcygeum, which presents itself as a dense cluster of mesenchyme running from the hindgut towards the os coccygis. Attachment of the m. levator ani to the os coccygis is not visible; it is lost in the ligamentum anococcygeum before the os coccygis is reached. The $\mathrm{m}$. levator ani shows a decreasing differentiation after it has passed the sphincter complex and is lost in the ligamentum anococcygeum.

\subsubsection{Musculus coccygeus}

At the surface of the most dorsal part of the corpus ossis ischii, just above the point where the $\mathrm{m}$. obturatorius internus leaves the pelvis, the $\mathrm{m}$. coccygeus appears (Figure $17 \mathrm{~mm} .4$ ). At its point of origin no sign of a developing spina ischiadica can be noted, nor can the arcus tendineus levatoris ani be identified in this region.

Following the m. coccygeus towards the os coccygis its volume increases slightly. The level of muscular differentiation decreases as the $\mathrm{m}$. coccygeus travels towards the os coccygis. Its level of differentiation is higher in the region of the 
corpus ossis ischii.

A subdivision in a ventral and dorsal part is present, although it is difficult to identify the separate parts in all sections. The subdivision becomes evidently clear when the m. coccygeus is pierced by a nerve (Figure 17mm.5). The individual direction of the ventral and dorsal part can not be identified as the level of differentiation decreases towards the os coccygis and os sacrum.

The distance between the dorsal edge of the $\mathrm{m}$. levator ani and the ventral edge of the $\mathrm{m}$. coccygeus appears to be much smaller than in the older embryos and fetuses. The two muscles almost meet (Figure $17 \mathrm{~mm} .4$ and Figure 17mm.5).

\subsubsection{Musculus sacrococcygeus ventralis}

The $\mathrm{m}$. sacrococcygeus ventralis cannot be identified in these embryos.

\subsection{Stage 17 and earlier}

In the embryonic stages preceding stage 18, no muscles of the pelvic diaphragm could be determined by the presence of (striated) muscle fibers. Clustering of mesenchymal cells in histological identifiable muscles or fascia is not visible in the HE-stained sections available. The clustering of mesenchymal cells is mandatory to identify the different pelvic structures, since the HE-staining cannot distinguish the future histological fait of the different mesenchymal cells. This is a disadvantage of the HE-staining in the early period of embryological development and makes it impossible to follow the development of the pelvic diaphragm muscles before stage 18 .

Nowadays the availability of different antibodies gives the opportunity to distinguish the various developing structures in the mesenchyme. This would make it possible to identify the mesenchymal cells forming the pelvic diaphragm at earlier embryological stages. Ethical issues however prevented us from gathering human embryos for antibody staining. The staining methods have to focus on developing skeletal muscle cells and on developing fascia.

Striated cells express myoglobin, desmin, alpha-smooth muscle actin, and occasionally
S-100, vimentin, and Leu-7. Other antigens such as myosin, creatine kinase, beta-enolase, and titin are less sensitive. Staining the mesenchyme with these markers will identify the mesenchymal cells differentiating into skeletal muscle cells.

Fascia consists of connective tissue cells, forming large amounts of collagen mainly Type I and Type III. Type III is produced by fibroblasts before the stronger Type I collagen is synthesized. For classic histological staining of collagen Masson trichrome and methyl violet stains can be used. Combining these staining techniques with an immunohistochemical approach, using anti-collagen Type I and III, will identify mesenchymal cells developing into connective tissue that constitutes the fascia.

We have shown the presence of mixed differentiation of the pelvic diaphragm muscles in the stage 18 embryos. At this stage embryos are present that do not show any histological clustering of mesenchymal cells. There are also embryos present that show clustering of mesenchymal cells as the earliest histological sign of differentiation. Even within a single embryo the presence of undifferentiated mesenchyme and early differentiating muscles is shown. This means that at stage 18 the histological development of the pelvic diaphragm begins. We therefore do not have to extend the period of interest before stage 18 to describe the development of the pelvic diaphragm muscles.

Future research, with the use of antibody staining, should focus on the origin of the mesenchymal cells forming the pelvic diaphragm muscles. In the stages $17 \mathrm{~mm}$ to $20 \mathrm{~mm}$ CRL we have described the presence of mesenchymal clustering in bands forming either muscle or fascia. This arises a second interesting question for future research. How do the different mesenchymal origins of the muscles and fascias interact? Does mesenchymal clustering of the future fascia precede the formation of the muscle's mesenchyme, or the other way around? It could well be that the formation of fascia from mesenchyme is dependent of the developmental stage of the muscle which it surrounds. 

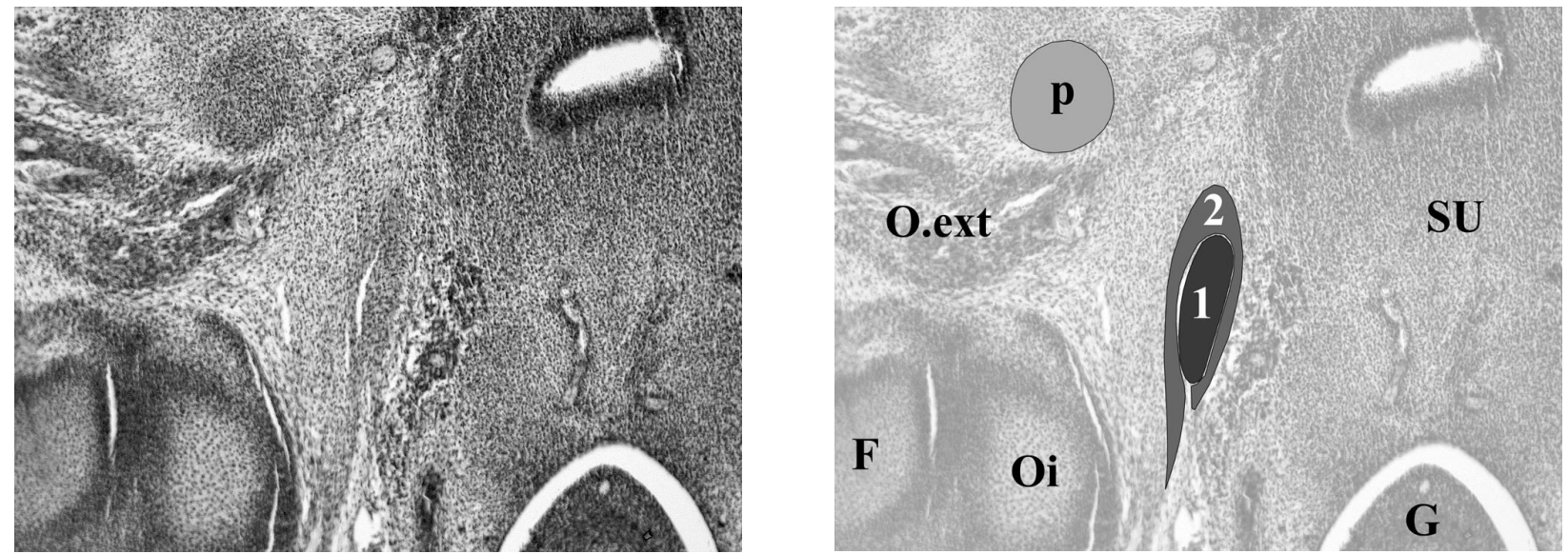

Figure 17mm.1

F, femur; $\mathbf{G}$, hindgut; O.ext, m. obturatorius externus; $\mathbf{O i}$, os ischii; $\mathbf{p}$, ramus inferior os pubis; $\mathbf{S U}$, sinus urogenitalis; $\mathbf{1}$, m. levator ani; $\mathbf{2}$, developing fascia.

The ramus inferior ossis pubis is outlined in chondroficating cells. No cartilage is present yet. The m. levator ani is formed by clustered mesenchyme, surrounded by a layer of cells representing the developing fascia of the muscle. The fascia stretches out dorsally towards the dorso-lateral side of the os ischii.
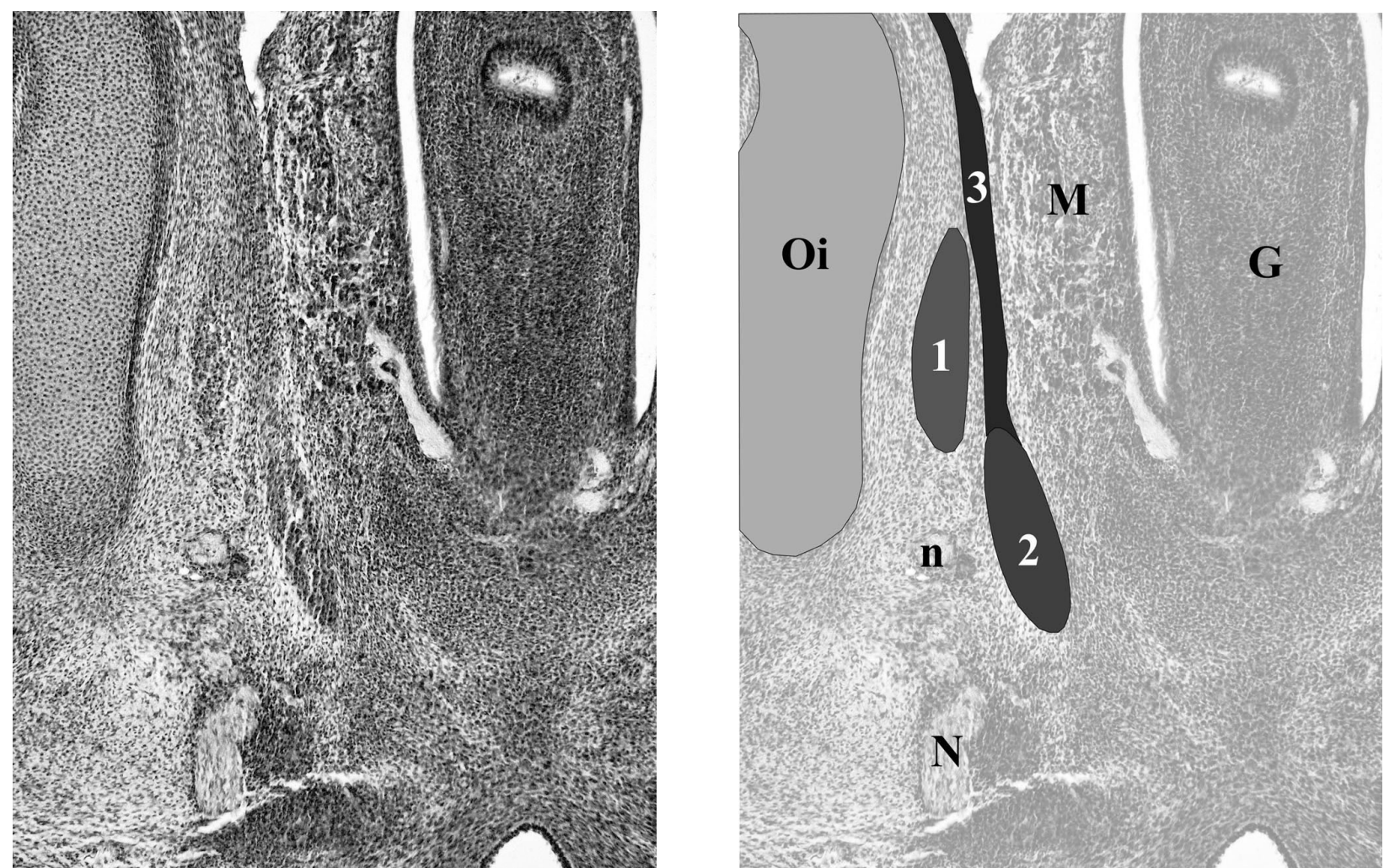

\section{Figure 17mm.2}

$\mathbf{G}$, hingut; $\mathbf{M}$, embryonic mesothelium of sinus urogenitalis, containing small blood vessels; $\mathbf{N} / \mathbf{n}$, nervus pudendus and branch; $\mathbf{O i}$, os ischii; $\mathbf{1}$, m. obturatorius internus; $\mathbf{2}, \mathrm{m}$. levator ani; $\mathbf{3}$, developing fascia of $\mathrm{m}$. levator ani. The level of the section photographed is just in front of the anal sphincter complex. The level of muscular differentiation of the levator ani has increased compared to the level at the os pubis. 

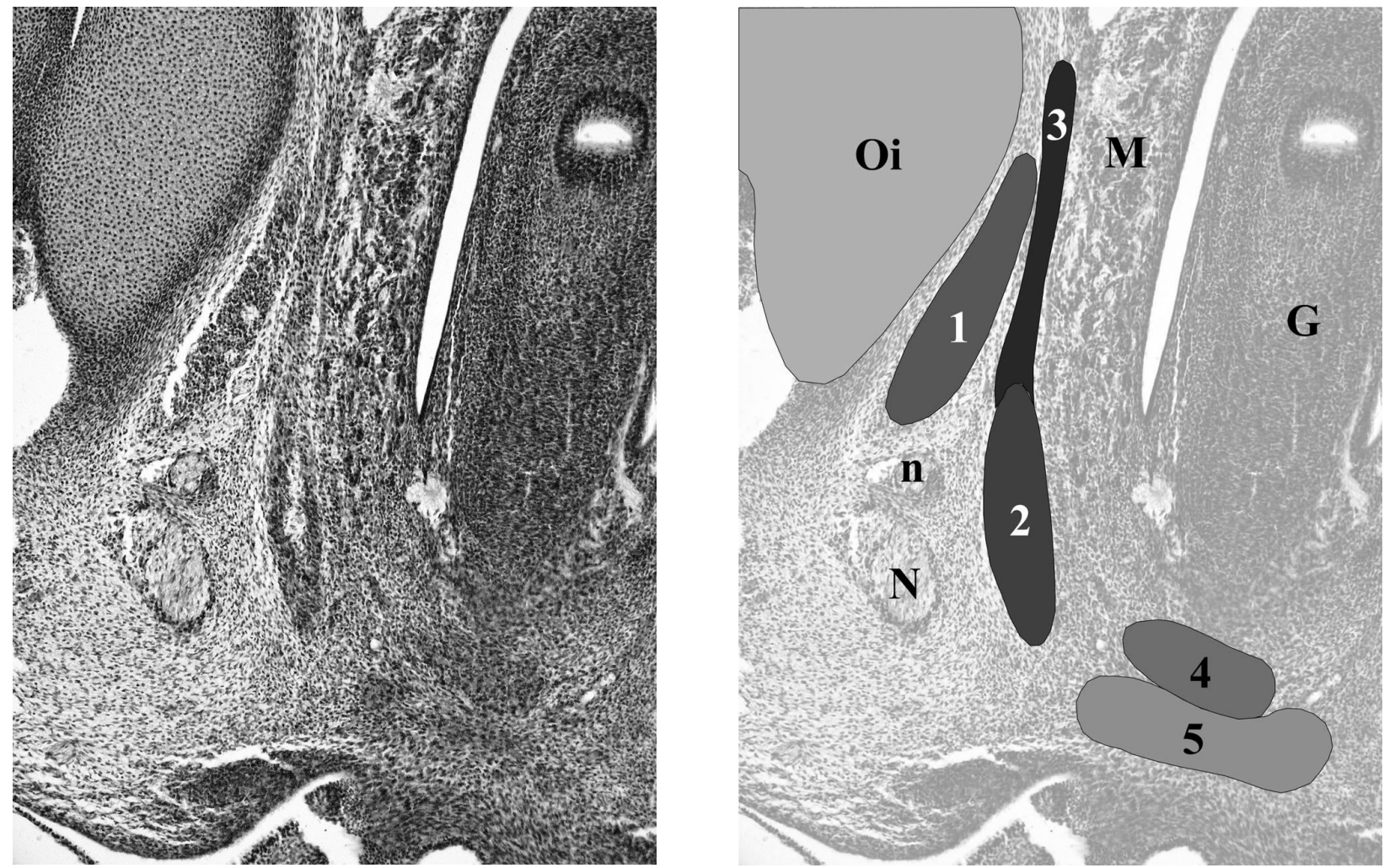

Figure 17mm.3

G, hingut; M, embryonic mesothelium of sinus urogenitalis, containing small blood vessels; $\mathbf{N} / \mathbf{n}$, nervus pudendus and branch; $\mathbf{O i}$, os ischii; $\mathbf{1}$, m. obturatorius internus; $\mathbf{2}, \mathrm{m}$. levator ani; $\mathbf{3}$, developing fascia of $\mathrm{m}$. levator ani; $\mathbf{4}$, deep part anal sphincter; $\mathbf{5}$, superficial part anal sphincter. The levator ani approaches the anal sphincter complex. The fossa ischiorectalis is visible with the nervus pudendus. 

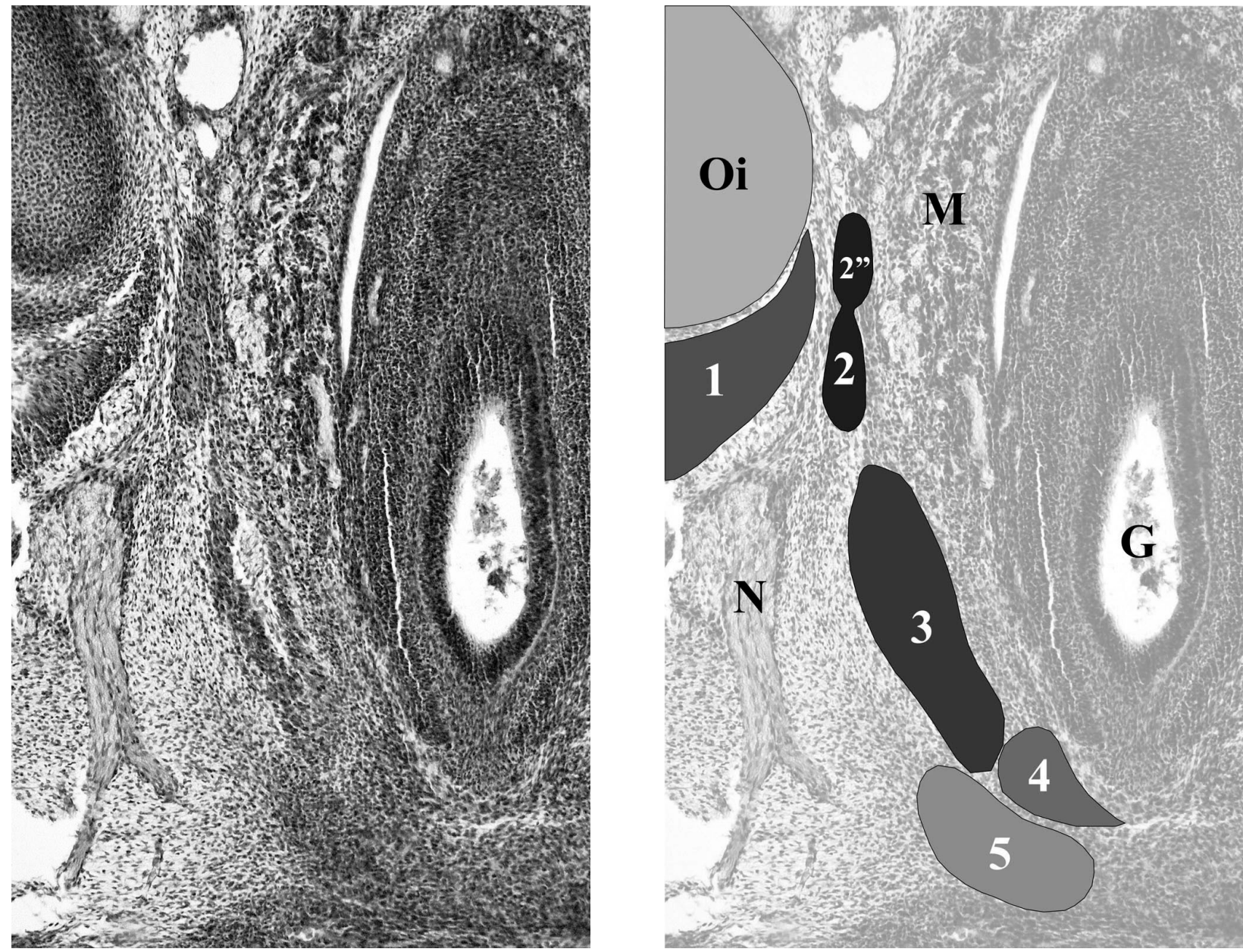

Figure 17mm.4

$\mathbf{G}$, hingut; $\mathbf{M}$, embryonic mesothelium of sinus urogenitalis, containing small blood vessels; $\mathbf{N}$, nervus pudendus; $\mathbf{O i}$, os ischii; $\mathbf{1}$, m. obturatorius internus; 2, m. coccygeus; 2", ligamentum sacrospinale; $\mathbf{3}$, m. levator ani with nerve inside; $\mathbf{4}$, deep part anal sphincter; $\mathbf{5}$, superficial part anal sphincter.

The $\mathrm{m}$. obturatorius is leaving the pelvis. The m. levator ani attaches to the deep anal sphincter complex. 

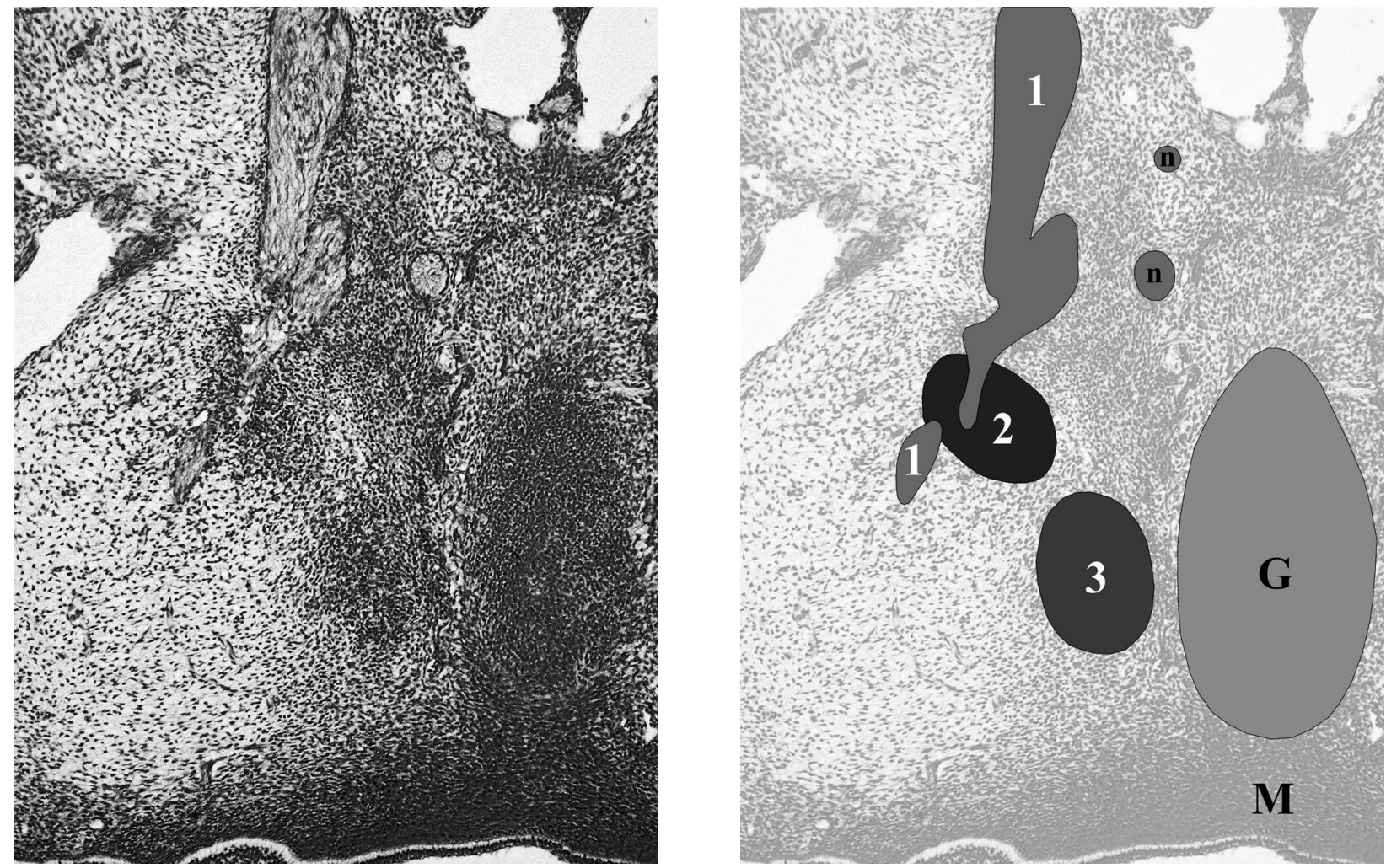

Figure 17mm.5

$\mathbf{G}$, hindgut (serosa); $\mathbf{M}$, anal membrane with last part of sphincter complex; $\mathbf{n}$, small branches of plexus pelvicus; $\mathbf{1}$, ramus ventralis S-I continuing in nervus pudendus; $\mathbf{2}, \mathrm{m}$. coccygeus; $\mathbf{3}, \mathrm{m}$. levator ani.

The level of the section photographed is just behind the hindgut. The $\mathrm{m}$. levator ani lost contact to the sphincter complex and travels towards the os coccygis. It's level of differentiation decreases. The m. coccygeus is pierced by a branch of the nervus pudendus, causing separation in a dorsal and ventral part. 


\section{PART 4}

\section{Summary and Conclusions}

CONTENTS:

4 - General aspects

4.1 - Musculus obturatorius INTERNUS

4.2 - Musculus LeVATOR ANI

4.3 - Musculus coccygeus

4.4 - Clinical implications

Samenvatting in Het Nederlands

REFERENCES

CUrriculum Vitae 


\section{General aspects}

This topographical description of the development of the pelvic diaphragm muscles indicates that the start of strong mesenchyme clustering and differentiation into muscle fibers is at stage 18-19 (17 mm CRL). Van der Putte [2005] describes the presence of mesenchyme in the puborectalis area in $13 \mathrm{~mm}$ embryos. We could not find this mesenchymal clustering in embryos smaller than $17 \mathrm{~mm}$; we did find the $\mathrm{m}$. levator ani to be more differentiated in the anal sphincter area than in the area towards the os pubis and os coccygis. Mesenchymal clustering present in $13 \mathrm{~mm}$ embryos thus makes sense. A fully developed pelvic diaphragm is present in the early fetal period at stage $43-50 \mathrm{~mm}$.

Following the development backwards, differentiation of the mesenchyme into striated muscle fibers within the pelvic diaphragm diminishes and this makes it difficult to identify the pelvic diaphragm muscles in the early embryonic stages. Nevertheless, by knowing the topography of the muscles in the later stages, and carefully examining mesenchymal clustering, the earliest stages could be interpreted.

Differentiation during development has an automatic component [Chandebois and Faber, 1983]. "In a homogeneous cell population autonomous progression is an automatic process based on a continuous exchange of information (homotypic interactions) which is effected through cell contact relations. The program for this autonomous progression is not communicated to the individual cells of the population at the time of determination. Rather, the program assigns to the cells a certain elementary social behavior, which is the basis for the structuring of the population [Chandebois and Faber, 1983].

Mesenchymal clustering will thus automatically produce the striated fibers of the muscles involved. It is this automation, followed backwards, that ensures that the use of topography and mesenchymal clustering effectively demonstrates the pelvic diaphragm muscle development.

One should note that even in $17 \mathrm{~mm}$ embryos the anal sphincter complex is easily recognizable and contains muscle fibers. The anal sphincter complex is also the place where the earliest differentiation of muscle fibers of the levator ani is noticed. In fact, it is the contact zone between the $\mathrm{m}$. levator ani and the deep part of the $\mathrm{m}$ sphincter ani externus that is recognizable up to $17 \mathrm{~mm}$ CRL.

\subsection{Musculus obturatorius internus}

The $\mathrm{m}$. obturatorius internus plays an important role in the structure of the pelvic diaphragm. It covers the lateral walls of the pelvic cavity. Over its inner surface lays the arcus tendineus levatoris ani, which fixes the $\mathrm{m}$. levator ani to the pelvic walls. It also acts as a landmark in the identification of the pelvic diaphragm muscles.

In adults the $\mathrm{m}$. obturatorius internus is described as a muscle originating from the margins of the foramen obturatum, the medial surface of the os pubis, the medial aspect of the os ischii and the inner surface of the membrana obturatoria [Hafferl, 1969]. It runs towards the incisura ischiadica minor where it leaves the pelvic cavity through the foramen ischiadicum minus to insert on the inner surface of the trochanter major (fossa trochanterica) as muscle fibers or as a tendon. Nerve branches directly arising from the plexus sacralis innervate the muscle.

Because of the lack of literature on the $m$. obturatorius internus in humans, and because of its role in the pelvic diaphragm, we have studied the development of this muscle in the previous described human embryos and fetuses. 


\subsubsection{Summary}

The $\mathrm{m}$. obturatorius internus first appears in the pelvic cavity of embryos with a crown rump length of $17 \mathrm{~mm}$, at about 49 days post conception. In this period the growing embryo should have reached developmental stage 18-19. In younger embryos, only mesenchyme is present, making it impossible to differentiate muscular development with the HE-staining of the available embryonic sections.

\section{$17 \mathrm{~mm} \mathrm{( \pm} 49$ days post conception, stage} 18-19). At the inner surface of the os ischii at the upper level of the ramus ossis ischii a condensation of cells appears, surrounded by mesenchymal cells. It curves around the dorsal margin of the os ischii, leaving the pelvic cavity at a level just below the future spina ischiadica and runs towards the head of the femur. This was determined as the developing $\mathrm{m}$. obturatorius internus and its developing fascia. The muscle does not show any striation or strands as a sign of early development. The membrana obturatoria has not developed yet. Instead, a broad layer of mesenchyme fills the foramen obturatum. Figure 4.1.1 is a schematic representation of the muscle, showing that its ventral extension is not reaching the dorsal margin of the foramen obturatum.

22-23 mm ( \pm 53-54 days post conception, stage 21). The $\mathrm{m}$. obturatorius internus has extended slightly caudal over the inner aspect of the ramus ossis ischii and slightly ventral reaching the dorsal margin of the foramen obturatum. The dorsal extension towards the femur head remains identical (Figure 4.1.2). It now begins to show formation of muscle fibers. The membrana obturatoria has not developed yet, but is outlined in mesenchyme.

28-30 mm ( $\pm 58-59$ days post conception, stage 23). At the end of the embryonic period the $\mathrm{m}$. obturatorius internus has started to cover part of the foramen obturatum (Figure 4.1.3). It has extended mostly in a ventral and caudal direction following the lower margin of the foramen obturatum, i.e. the ramus ossis ischii, but also slightly in a cranial direction towards the corpus ossis ischii. The muscle nearly covers the dorsal half of the foramen obturatum, has clear strands and is covered by a fascia that does not appear to have reached the os pubis. The foramen obturatum is filled by mesenchyme, that starts to condense, forming a more or less recognizable membrana obturatoria.

34-35 mm ( \pm 9 weeks post conception). At the beginning of the fetal period the $\mathrm{m}$. obturatorius internus has extended further in a ventralcaudal direction, following the lower margin of the foramen obturatum, and in a ventral-cranial direction, covering the corpus ossis ischii. The muscle now covers about three quarters of the foramen obturatum, but has not reached the future canalis obturatorius yet (Figure 4.1.4). The fascia of the $\mathrm{m}$. obturatorius has already reached the os pubis. In the embryos described, the dorsal extension of the muscle from the incisura ischiadica minor towards the femur head consists of fascia and not of muscle fibers. The membrana obturatoria is now well recognizable as a small layer of connective tissue between the $\mathrm{m}$. obturatorius internus and externus. At the level of the nervus obturatorius it has not yet developed into a clear canalis obturatorius.

42-43 mm ( \pm 10 weeks post conception). The $\mathrm{m}$. obturatorius internus has extended further in a ventral and cranial direction towards the future canalis obturatorius. It covers the foramen obturatum for more than three quarters, failing to reach the ramus superior ossis pubis (Figure 4.1.5). The fascia of the muscle is still attached to the os pubis. The membrana obturatoria shows progressing condensation around the nervus obturatorius, beginning to form a canalis obturatorius. 


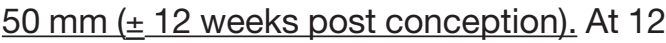
weeks post conception the $\mathrm{m}$. obturatorius internus has nearly reached its full extension, except for a small margin at the ventral caudal edge of the foramen obturatum. It has extended further in a ventral and cranial direction, surrounding the lower margin of the canalis obturatorius and almost reaching the incisura ischiadica major and linea arcuata. It has extended ventrally to insert on the os pubis (Figure 4.1.6). The canalis obturatorius has now developed completely. The dorsal extension towards the femur head consists of muscle fibers.

\subsubsection{Conclusion}

One very important conclusion can be drawn from the described development of the $\mathrm{m}$. obturatorius internus, namely that the muscle develops in a dorsal to ventral direction. We were not able to follow the development of the muscle in embryos younger than $17 \mathrm{~mm}$ C.R.L., but the fetal results of the dorsal to ventral development makes us conclude that the margins of the foramen obturatum and the caudal edge of the foramen ischiadicum majus are not the origins of the $\mathrm{m}$. obturatorius internus, but the insertions.

With the use of specific antibodies it would be possible to follow the development of the $\mathrm{m}$. obturatorius internus in younger embryos, to find the origin of the muscle. We have seen in the described embryos that the extra-pelvic part of the $\mathrm{m}$. obturatorius internus (from incisura ischiadica minor towards trochanter major femoris) can be muscle, fascia, and/or tendon. This is in accordance with the adult situation as described before. We have also shown that the fascia of the m. obturatorius internus precedes the developing muscle, as it reaches the os pubis before the muscle fibers do. It might therefore be possible that the origin of the fascia and the muscle fibers of the m. obturatorius internus is situated at the trochanter major femoris, or at the level of the in- cisura ischiadica minor, or both.

The development of the membrana obturatoria is interesting. It shows a developmental trend similar to that of the m. obturatorius internus. In other words, the development of the membrana obturatoria precedes that of the $\mathrm{m}$. obturatorius internus in a ventral direction.

The development of the membrana obturatoria seems to be induced by the $\mathrm{m}$. obturatorius internus. Although the $\mathrm{m}$. obturatorius externus is already present before the obturatorius internus reaches the other side of the membrana obturatoria, the area of the membrana remains mesenchyme-like. The further the $\mathrm{m}$. obturatorius internus extends over the membrana obturatoria, the more typical the connective tissue appearance of the membrana. This induction or heterotypic action follows certain rules: "The inducer re-initiates or deflects the course of autonomous progression but it does not establish its program. It selects one program from among others, which are already being executed. The execution of the program - which under certain experimental conditions may continue or be accelerated in the absence of the inducer - consists in the stimulation of certain luxury metabolic strategies. The cells become competent to respond to the action of the inducer as soon as the inductive stimulus suffices to raise those strategies above a threshold beyond which they manifest themselves in visible structure [Chandebois and Faber, 1983]". The autonomic progression of the mesenchymal area at the future membrana obturatoria is promoted to differentiate into connective tissue, with the $\mathrm{m}$. obturatorius internus as inducer. 


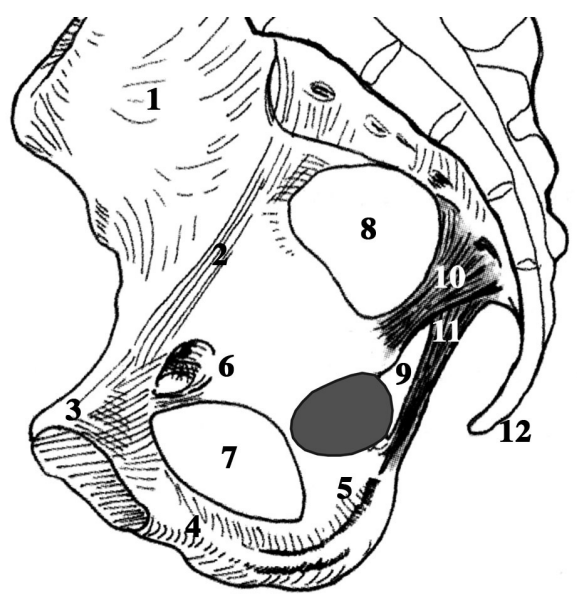

Figure 4.1.1: $17 \mathrm{~mm}$

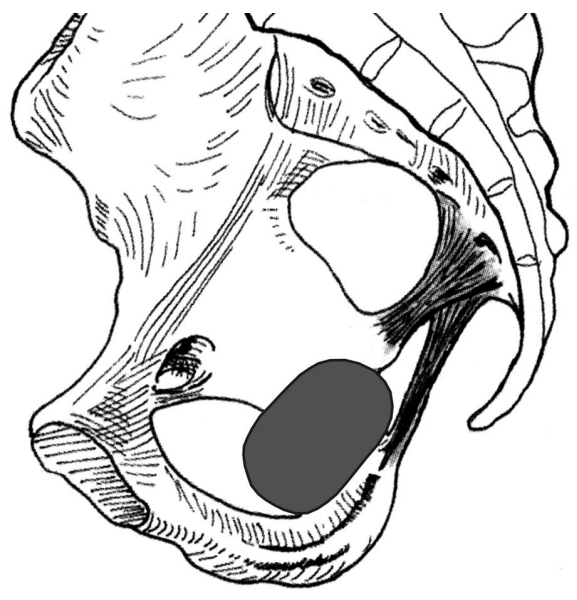

Figure 4.1.3: $28 \mathrm{~mm}$

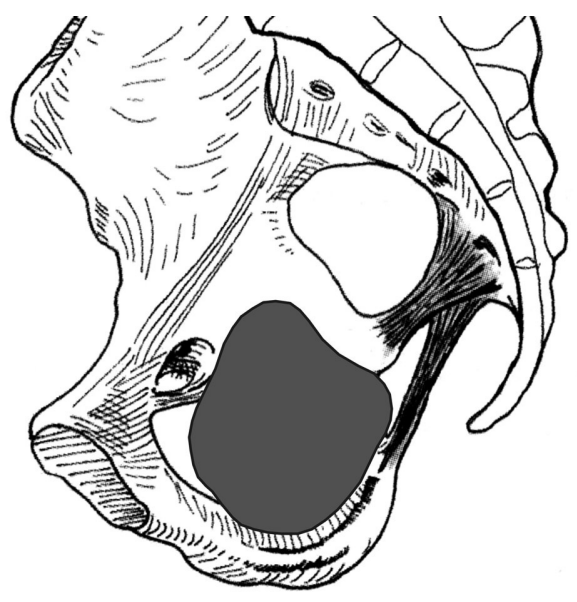

Figure 4.1.5: $43 \mathrm{~mm}$

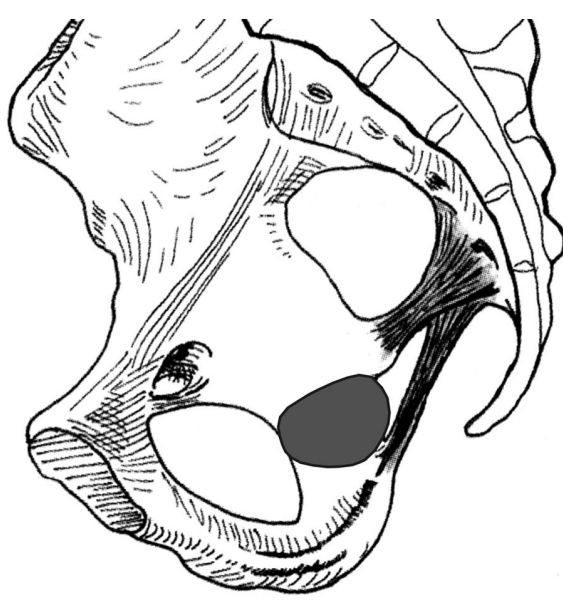

Figure 4.1.2: $23 \mathrm{~mm}$

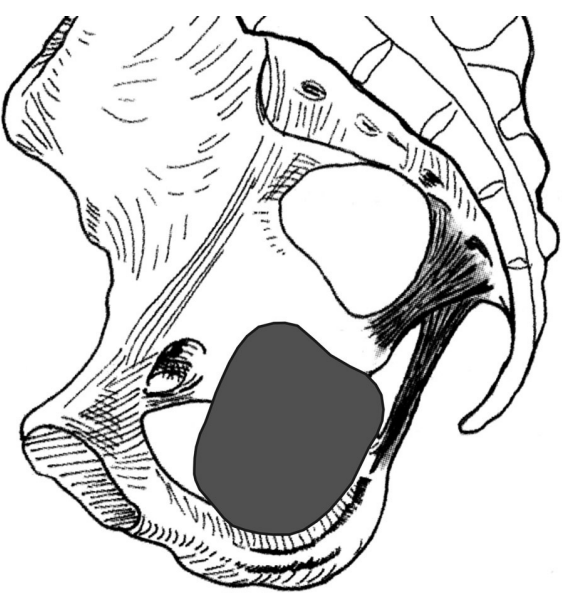

Figure 4.1.4: $34 \mathrm{~mm}$

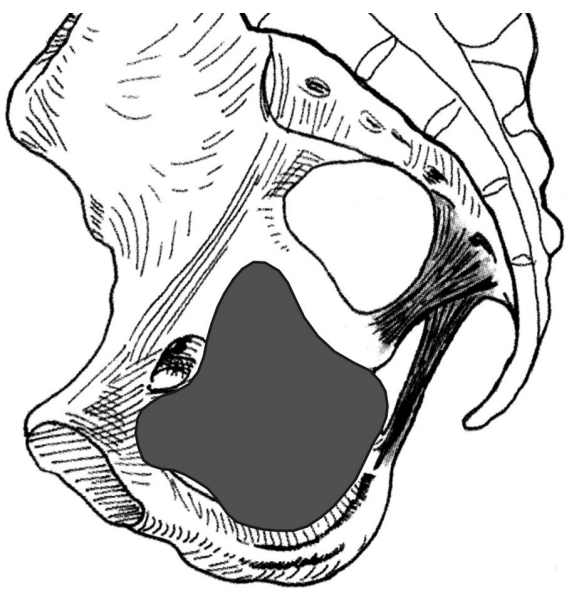

Figure 4.1.6: $50 \mathrm{~mm}$

Figure 4.1.1-1.6

Schematic representation of developing $\mathrm{m}$. obturatorius internus (in grey), projected on the mature bony pelvis.

$\mathbf{1}$, ala ossis ilii; $\mathbf{2}$, linea arcuata; $\mathbf{3}$, (ramus superior) os pubis; $\mathbf{4}$, ramus inferior ossis pubis; $\mathbf{5}$, ramus ossis ischii / tuber ischiadicum; $\mathbf{6}$, canalis obturatorius; $\mathbf{7}$, foramen obturatum; $\mathbf{8}$, foramen ischiadicum majus; $\mathbf{9}$, foramen ischiadicum minus; $\mathbf{1 0}$, ligamentum sacrospinale; $\mathbf{1 1}$, ligamentum sacrotuberale; 12, os coccygis 


\subsection{Musculus levator ani}

The $\mathrm{m}$. levator ani is the main muscle that constitutes the pelvic diaphragm. Difference of opinion exists on the presence of a subdivision into distinct muscles. The $\mathrm{m}$. levator ani is described as a single muscle, subsequently divided into an imaginary pubococcygeal and iliococcygeal part and as a group of muscles (see part one). This group of muscles then consists of the $\mathrm{m}$. pubococcygeus and the $\mathrm{m}$. iliococcygeus. Some authors describe the presence of a third muscle, the $m$. puborectalis. Even the m. coccygeus ( $\mathrm{m}$. ischiococcygeus) is included in the levator ani by some authors.

Little is known about the development of the $\mathrm{m}$. levator ani. The development during the embryonic period is only described by Popowsky [1899] and Power [1948]. Popowsky concluded that the $\mathrm{m}$. levator ani developed from the $\mathrm{m}$. coccygeus by ventral migration of part of its muscle fibers. Power described the $\mathrm{m}$. levator ani as part of the $\mathrm{m}$. rectus abdominis, separated by ingrowth of the pubic bone. Fritsch [1994] discussed the development of the $\mathrm{m}$. levator ani in the fetal period, although she only made observations on the anatomical presence and extension of the $\mathrm{m}$. levator ani in different fetal stages.

No description of the actual embryonic and fetal development of the $\mathrm{m}$. levator ani, progressing over time, could be found. We therefore have studied and described the embryological and early fetal development of the $\mathrm{m}$. levator ani and defined it over time.

\subsubsection{Summary}

The first appearance of a developing $\mathrm{m}$. levator ani is found in embryos with a CRL of $17 \mathrm{~mm}$. In younger embryos only mesenchyme is present, making it impossible to differentiate muscular development with the HE-staining of the available embryonic sections.
$17 \mathrm{~mm}( \pm 49$ days post conception, stage

18-19). The $\mathrm{m}$. levator ani appears as a single muscle at the level of the external anal sphincter complex. It is attached to the deep part of the $\mathrm{m}$. sphincter ani externus and radiates around the hindgut and sinus urogenitalis towards the os pubis and the os coccygis. The $\mathrm{m}$. levator ani is not attached to the sinus urogenitalis. Extending ventrally towards the os pubis the muscular differentiation of the mesenchyme decreases. The $\mathrm{m}$. levator ani ends as mesenchyme medially and posteriorly of the developing os pubis. Extending dorsally towards the os coccygis its level of muscular differentiation also decreases. This decrease in differentiation lets us conclude that the $\mathrm{m}$. levator ani starts to develop as a part of the external anal sphincter complex and then extends towards the os pubis and os coccygis, radiating around the hindgut and sinus urogenitalis. Figure 4.2.1 shows a schematic representation of the $\mathrm{m}$. levator ani in an artistic impression of the developing bony pelvis. Ventrally, the left and right os pubis are wide apart. The ventral parts of the left and right $\mathrm{m}$. levator ani end between the two pubic bones, without attachment to these bones. Radiating around the rectum and the sinus urogenitalis the $\mathrm{m}$. levator ani runs towards the midline, eventually ending in front of the os coccygis at the level of the developing ligamentum anococcygeum. The lateral extension of the developing muscle fibers is limited to a small band. The muscle is surrounded by its developing fascia that can already be seen extending over the $\mathrm{m}$. obturatorius internus towards the future arcus tendineus levatoris ani.

\section{2-23 mm ( \pm 53-54 days post conception,} stage 21). The $\mathrm{m}$. levator ani now completely consists of fully differentiated muscle fibers. Ventrally it is not yet attached to the developing os pubis. The fascia of the muscle however is attached to the developing endopelvic fascia, connecting it to the ramus inferior ossis pubis. The left and right 
os pubis have extended towards the midline, now reaching in front of the ventral part of the $\mathrm{m}$. levator ani. The ventral to dorsal extension of the $\mathrm{m}$. levator ani has not changed. Dorsally the $\mathrm{m}$. levator ani extends towards the midline and is attached to the developing ligamentum anococcygeum. At this stage of development, the $\mathrm{m}$. levator ani starts to extend laterally and cranially at a level in between the hindgut and the sinus urogenitalis (Figure 4.2.2). The $\mathrm{m}$. levator ani is growing towards the ventral part of the arcus tendineus levatoris ani, following its preceding fascia. The muscle has not shown any progression towards the midline.

28-30 mm ( $\pm 58-59$ days post conception, stage 23). Reaching the end of the embryonic period, the $\mathrm{m}$. levator ani has shown acceleration in its development. The left and right os pubis have reached the midline, forming the symphysis pubica. With this 'outgrowth' of the os pubis and their contact as the symphysis pubica, the $\mathrm{m}$. levator ani has extended medially at its ventral margin. It is now more clearly enclosing the sinus urogenitalis. The outgrowth of the os pubis towards the midline and the attachment of the $\mathrm{m}$. levator ani to the os pubis create the hiatus urogenitalis.

The levator ani is not attached to the sinus urogenitalis. At its ventral margin the $\mathrm{m}$. levator ani has also extended cranially and dorsally, following the arcus tendineus levatoris ani. Projecting over the foramen obturatum, it is now covering the ventral half of the foramen obturatum and the m. obturatorius internus (Figure 4.2.3). The dorsal extension of the $\mathrm{m}$. levator ani has slightly progressed towards the tip of the os coccygis. It is still attached to the ligamentum anococcygeum and not to the os coccygis itself.

34-35 mm ( \pm 9 weeks post conception). At the beginning of the fetal period the $\mathrm{m}$. levator ani has shown little progression (Figure 4.2.4). It has not extended further dorsally towards the os coccygis nor has it extended dorsally and cranially, following the arcus tendineus levatoris ani. The ventral margin of the levator ani however, has extended further towards the inner aspect of the ramus inferior ossis pubis. With the progressing development of the endopelvic fascia the distance between the os pubis and the $\mathrm{m}$. levator ani has also decreased. Between the sinus urogenitalis and the rectum, the $\mathrm{m}$. levator ani has extended towards the midline. The formation of a separate hiatus urogenitalis and hiatus ani now becomes visible. There is no attachment of the $\mathrm{m}$. levator ani to the sinus urogenitalis noted.

42-43 mm \pm 10 weeks post conception). One week later in its development, the $\mathrm{m}$. levator ani has again shown a large progression. Towards the os coccygis it has extended further, now almost reaching the tip of the os coccygis. The left and right $\mathrm{mm}$. levatores ani are projected near the lateral surface of the tip of the os coccygis. Attachment is made through the ligamentum anococcygeum. The most prominent progression is reached in the dorsal and cranial direction, following the arcus tendineus levatoris ani. The $\mathrm{m}$. levator ani now almost reaches the dorsal end of the arcus tendineus levatoris ani, near the developing spina ischiadica where the ATLA attaches (Figure 4.2.5). The $\mathrm{m}$. levator ani has shown no progression towards the midline, the future hiatus urogenitalis and hiatus ani are the same as 9 weeks post conception.

$50 \mathrm{~mm}$ ( \pm 12 weeks post conception). The $\mathrm{m}$. levator ani has shown a marked progression towards the midline, especially between the sinus urogenitalis and the rectum, at the level of the future centrum tendineum and behind the rectum at the level of the ligamentum anococcygeum. With the continuing development of the ligamentum anococcygeum the left and right musculi levatores ani are almost attached to each other, only separated by the ligamentum anococ- 
cygeum. The levator ani is now attached to the upper aspect of the ramus inferior ossis pubis on the ventral side. On the lateral side the $\mathrm{m}$. levator ani covers the pelvic outlet completely, following the arcus tendineus levatoris ani towards the future spina ischiadica. At twelve weeks post conception the $\mathrm{m}$. levator ani has almost developed completely (Figure 4.2.6). The adult situation is not yet reached at the level of the future centrum tendineum only.

\subsubsection{Conclusions}

Our developmental study presented shows that the $\mathrm{m}$. levator ani is one single muscle. There is no evidence of an anatomical subdivision in an $\mathrm{m}$. pubococcygeus, m. iliococcygeus, or m. puborectalis. Especially the existence of an $\mathrm{m}$. puborectalis or puborectal sling is denied by the presented results. No muscular fibers actually cross the midline, so the formation of a muscular sling around the rectum is improbable.

The $\mathrm{m}$. levator ani develops as a part of the external anal sphincter complex and is attached to the deep part of the $\mathrm{m}$. sphincter ani externus. It extends ventrally towards the os pubis encircling the sinus urogenitalis and dorsally towards the os coccygis. When the $m$. levator ani reaches the level of the os pubis, which is also caused by the ingrowth of the pubic bone (the hiatus urogenitalis is created), it starts to extend over the pelvic outlet.

This extension is not constant over time. Especially at the end of the embryonic period, when the symphysis pubica is formed, and between the ninth and tenth week post conception, accelerated development is noted. The first acceleration is caused by the growing pubic bone, which more or less drags the $\mathrm{m}$. levator ani towards the midline, outlining the hiatus urogenitalis. This ingrowth of the os pubis towards the midline is probably the basis for Powers [1948] view on the development of the pelvic diaphragm. The reason for the second acceleration is not clear.

After it reaches the pubic bone, the $\mathrm{m}$. levator ani extends dorsally and cranially over the pelvic outlet, following its developing fascia and the developing arcus tendineus levatoris ani. Different from Popowsky [1899] who described a ventral migration of muscle fibers, our study describes a dorsal migration. The left and right musculi levatores ani fan out over the pelvic outlet like 'a peacock spreading its tail feathers'.

The extension of the $\mathrm{m}$. levator ani towards the midline is mainly caused by external factors. As already described, the ventral medial extension is caused by the developing os pubis. The medial extension, between the sinus urogenitalis and the rectum, is caused by the developing centrum tendineum (perineal body), pulling the left and right levator ani towards each other (see the extensive research of van der Putte [2005] for further details on the development of the human perineum). Behind the rectum, the medial closure of the pelvic outlet by the left and right levator ani is mediated by the developing ligamentum anococcygeum. The ligamentum anococcygeum condensates from a broad mesenchymal band to a thin band of connective tissue, connecting the deep part of the $\mathrm{m}$. sphincter ani externus and the left and right $\mathrm{m}$. levator ani with the tip of the os coccygis.

The observations on the muscles of the pelvic diaphragm by Fritsch [1994a] are not shared. The existence of separate musculi pubococcygeus, iliococcygeus and puborectalis cannot be reproduced. Her description of the levator ani originating from the pelvic surface of the os pubis, is probably confounded by misinterpretation of the varying muscular differentiation of the $\mathrm{m}$. levator ani in the $17 \mathrm{~mm}$ stage, as noted earlier. The differences between male and female pelvic 


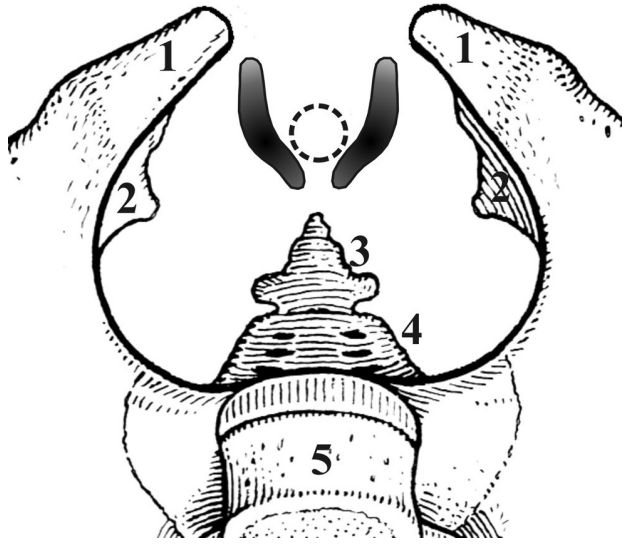

Figure 4.2.1: $17 \mathrm{~mm}$

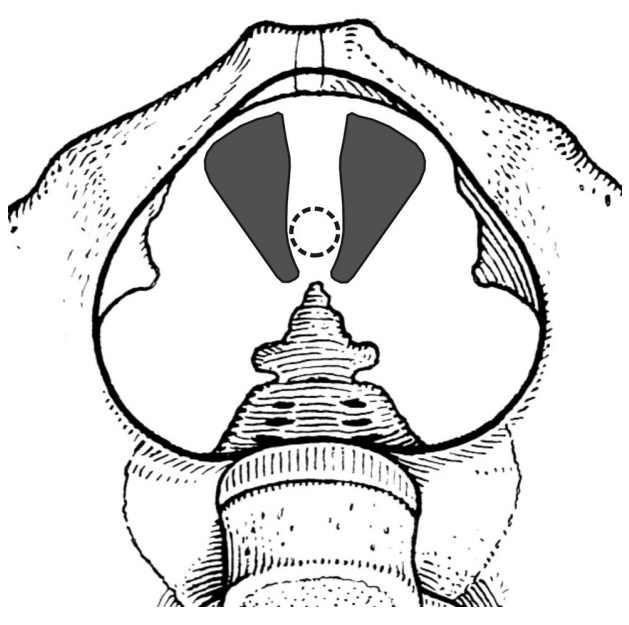

Figure 4.2.3: $28 \mathrm{~mm}$

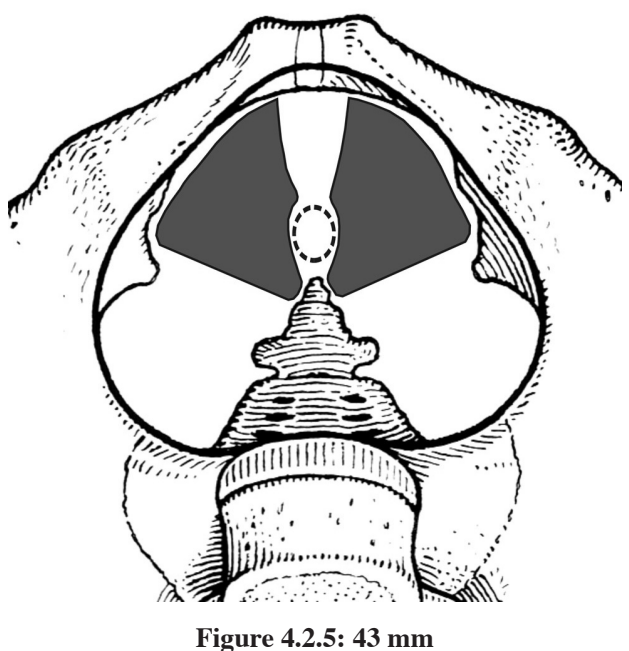

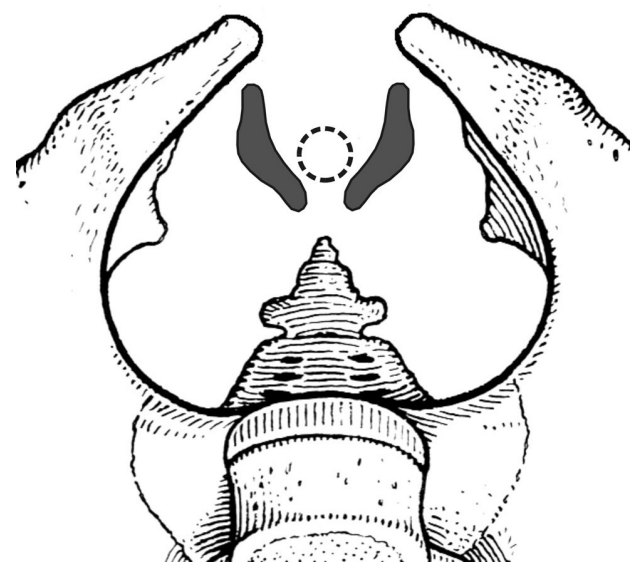

Figure 4.2.2: $23 \mathrm{~mm}$

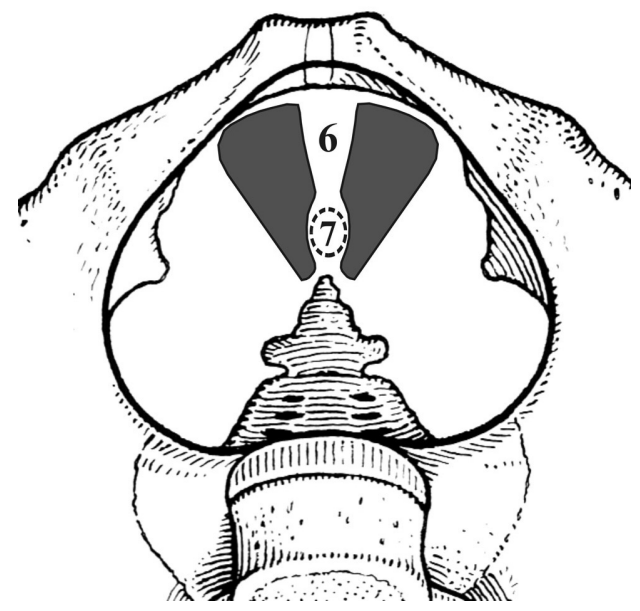

Figure 4.2.4: $34 \mathrm{~mm}$

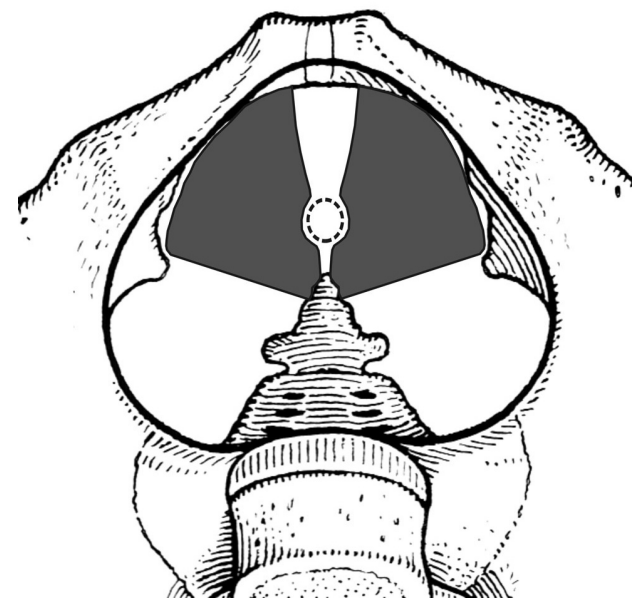

Figure 4.2.6: $50 \mathrm{~mm}$

Figure 4.2.1-2.6

Schematic representation of the developing $\mathrm{m}$. levator ani (in grey) projected on the mature bony pelvis. An artistic impression has been made for the pelvis, combining the adult bony pelvis with developing structures. In Figure 4.2.1. the muscular differentiation is represented in grey shadings with black representing differentiated muscle fibers and light grey representing mesenchyme.

1, os pubis; 2, developing spina ischiadica; 3, os coccygis; 4, os sacrum; 5, fifth lumbar vertebra; 6, hiatus urogenitalis; 7, hiatus ani; dotted line, outline rectum/anus. 
diaphragm, described by Fritsch, are not found in our study. The pelvic diaphragm develops independent from the sinus urogenitalis and therefore a sex-dependent difference in the composition of the pelvic diaphragm makes no sense. However, development of the urogenital diaphragm and perineum is sex-dependent though, as van der Putte [2005] demonstrated.

The development of the pelvic diaphragm is independent of the developing sinus urogenitalis and only indirectly dependent of the development of the rectum. The pelvic mediastinum described by Marani [2002] can only be partly reproduced in this study. The sinus urogenitalis is not anywhere directly attached to the $\mathrm{m}$. levator ani. The anchoring of the sinus urogenitalis to the pelvic diaphragm is made possible through the urogenital diaphragm. The $\mathrm{m}$. levator ani is not attached to the rectum but to the deep part of the external sphincter. This connection to the deep part of the external sphincter is responsible for the functional combined actions of the rectum and pelvic diaphragm. A complete free space for the individual free development of the pelvic organs, as described by Marani [2002] is thus only present for the urogenital organs and not for the anal sphincter area.

The projection of the pelvic outlet in the embryonic and fetal stages is to the front. Because of this projection the $\mathrm{m}$. levator ani extends more dorsally than cranially during its development. In later fetal life, with the formation of the lumbar lordosis, the formation of the promontorium and the backward stretching of the os coccygis, the pelvic outlet will rotate to its final position in a dorsal caudal projection. At that time the os pubis will be the lowest part of the bony pelvis and not the os coccygis [Marani 2002]. The $\mathrm{m}$. levator ani in the adult dorsal caudal projection would have shown extension in a more cranial direction. 


\subsection{Musculus coccygeus}

In adults, the m. coccygeus originates from the spina ischiadica and inserts on the lateral inner surface of the os sacrum and os coccygis. With the disappearance of a tail in humans, its function has shifted from motion to support [Thompson, 1899]. The $m$. coccygeus can therefore be considered part of the pelvic diaphragm. This shift to a solely supportive function is responsible for the construction of the muscle in adults. It is variably described as consisting of fascia or a combination of muscle fibers and fascia. In adults it rarely consists of only muscle fibers [Thompson, 1899]. The m. coccygeus is attached to, or forming part of, the ligamentum sacrospinale.

Apart from Popowsky's work [1899], no literature on the $m$. coccygeus as part of the developing pelvic diaphragm could be found. Popowsky describes the $m$. coccygeus as the origin of the developing $\mathrm{m}$. levator ani. The ventral fibers of the $m$. coccygeus migrate to the front forming the $\mathrm{m}$. levator ani. The development of the $\mathrm{m}$. coccygeus itself is not described by Popowsky.

\subsubsection{Summary}

The first appearance of a developing m. coccygeus is found in embryos with a CRL of $17 \mathrm{~mm}$. In younger embryos only mesenchyme is present, making it impossible to differentiate muscular development with the HE-staining of the available embryonic sections.

$17 \mathrm{~mm} \mathrm{( \pm} 49$ days post conception, stage 18-19). Just above the level where the $m$. obturatorius internus leaves the pelvis, the m. coccygeus appears. At this stage no developing spina ischiadica is noted. As it appears, the m. coccygeus shows striation as a sign of differentiation into muscle. This differentiation is lost following the $\mathrm{m}$. coccygeus towards the os coccygis, where it consists of mesenchyme. A closer study on the outline of the muscle reveals that it consists of a dorsal and a ventral part, both comprised of muscular tissue. Towards the os coccygis, the $\mathrm{m}$. coccygeus slightly enlarges in a ventral-dorsal dimension. It is lost in mesenchyme well before the os coccygis is reached. Figure 4.3.1 shows an impression of the $\mathrm{m}$. coccygeus, projected in a schematic representation of the developing bony pelvis. It has to be understood that the future spinae ischiadicae have been drawn in to facilitate a better understanding of the actual position of the $m$. coccygeus, while in fact they do not yet exist.

22-23 mm ( \pm 53-54 days post conception, stage 21). The $m$. coccygeus now shows complete striation. It originates at the level of the future spina ischiadica. The ventral-dorsal dimension of the lateral half of the muscle has increased (Figure 4.3.2). The medial half has extended towards the os coccygis, but without progression in dimension. It is lost in connective tissue extending up to the lateral aspect of the os coccygis and os sacrum. The $m$. coccygeus has a ventral and a dorsal part. The dorsal part has the largest volume and travels towards the os sacrum, the smaller ventral part towards the os coccygis.

28-30 mm $\pm 58-59$ days post conception, stage 23). At this stage only the medial part near the os coccygis has extended in the ventral dorsal diameter (Figure 4.3.3). Near the future spina ischiadica, which still cannot be identified, the $m$. coccygeus has shown no progression. The $\mathrm{m}$. coccygeus has also not progressed any further towards the os coccygis and os sacrum. A dorsal and ventral part is noted. In contrast to the earlier stages the ventral part has increased in size, but remains smaller than the dorsal part. The ventral part travels towards the lateral aspect of the os coccygis and the dorsal part towards the lateral aspect of the os sacrum.

34-35 mm ( \pm 9 weeks post conception). The $m$. coccygeus has now extended further to- 
wards the os coccygis and os sacrum. Its overall ventral-dorsal dimension has extended a little (Figure 4.3.4). The most important change has taken place between the ventral and dorsal part of the m. coccygeus. At the lateral part, near the future spina ischiadica, the dorsal part of the muscle is larger than the ventral part. At the medial part, towards the os coccygis, the ventral part becomes larger than the dorsal part. The future spina ischiadica starts to develop, and is now discernable as a mesenchymal condensation.

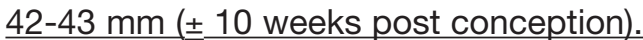

The spacious volume of the $m$. coccygeus has hardly changed. It has only extended further towards the os coccygis (Figure 4.3.5). The ventral part of the m. coccygeus, however, has now become the biggest part of the $m$. coccygeus. The dorsal part has changed into a narrow band of muscle fibers.

$50 \mathrm{~mm}$ ( \pm 12 weeks post conception). The $\mathrm{m}$. coccygeus has almost reached the margins present in the adult situation, except for its insertion on the os coccygis and os sacrum (Figure 4.3.6). The developing spina ischiadica is outlined in developing cartilage. The $\mathrm{m}$. coccygeus clearly originates from this developing spina ischiadica. The ventral part of the $m$. coccygeus has fanned out and is much larger than the dorsal part. The dorsal part can be followed all the way to the lateral surface of the os sacrum, where it is lost in connective tissue inserting on the os sacrum. The dorsal part always remains attached to the ventral part. The ventral part travels towards the lateral surface of the os coccygis.

\subsubsection{Conclusions}

The developmental characteristics of the m. coccygeus indicate that the origin of the muscle is at the level of the future spina ischiadica, and its insertion on the lateral pelvic surface of the last sacral and first coccygeal vertebrae.
The described development of the m. coccygeus clearly demonstrates the reason for the close relationship of the $\mathrm{m}$. coccygeus and the ligamentum sacrospinale in the adult topographical anatomy. The $\mathrm{m}$. coccygeus develops in a ventral and dorsal part, always connected to each other. The ventral part increases in size during the embryonic and early fetal development and will form the actual $m$. coccygeus that is described in adult anatomy. With the progressing volume of the ventral part, the dorsal part decreases in volume and will form the ligamentum sacrospinale. In the described developmental stages, the $\mathrm{m}$. coccygeus and ligamentum sacrospinale are both constituted of muscle fibers. In the later fetal stages, or perhaps even after birth, the m. coccygeus and most certainly the ligamentum sacrospinale will have to degrade to fibrous tissue to explain the situation described in adult topographical anatomy. Since the spinae ischiadicae, for instance, reach their complete development in late childhood [Marani 2002], it could well be that the $\mathrm{m}$. coccygeus and ligamentum sacrospinale retain their muscular form up until that time. This can be an interesting subject for further research. Modern magnetic resonance imaging could be helpful in studying the composition of the m. coccygeus and ligamentum sacrospinale in children. From an embryological point of view it can already be concluded that the $\mathrm{m}$. coccygeus and ligamentum sacrospinale are constructed to perform the function of moving the os coccygis. With the evolutionary disappearance of the tail in humans they will eventually maintain a supportive function and transform to fascia: 'use it or loose it'.

The division of the $m$. coccygeus in a ventral and dorsal part also explains why Popowsky [1899] believed that the $\mathrm{m}$. levatoris ani developed out of ventrally migrating muscle fibers from the $\mathrm{m}$. coccygeus. In the late embryonic period he studied, the ventral part of the m. coccygeus is much smaller than the dorsal part, as is shown 

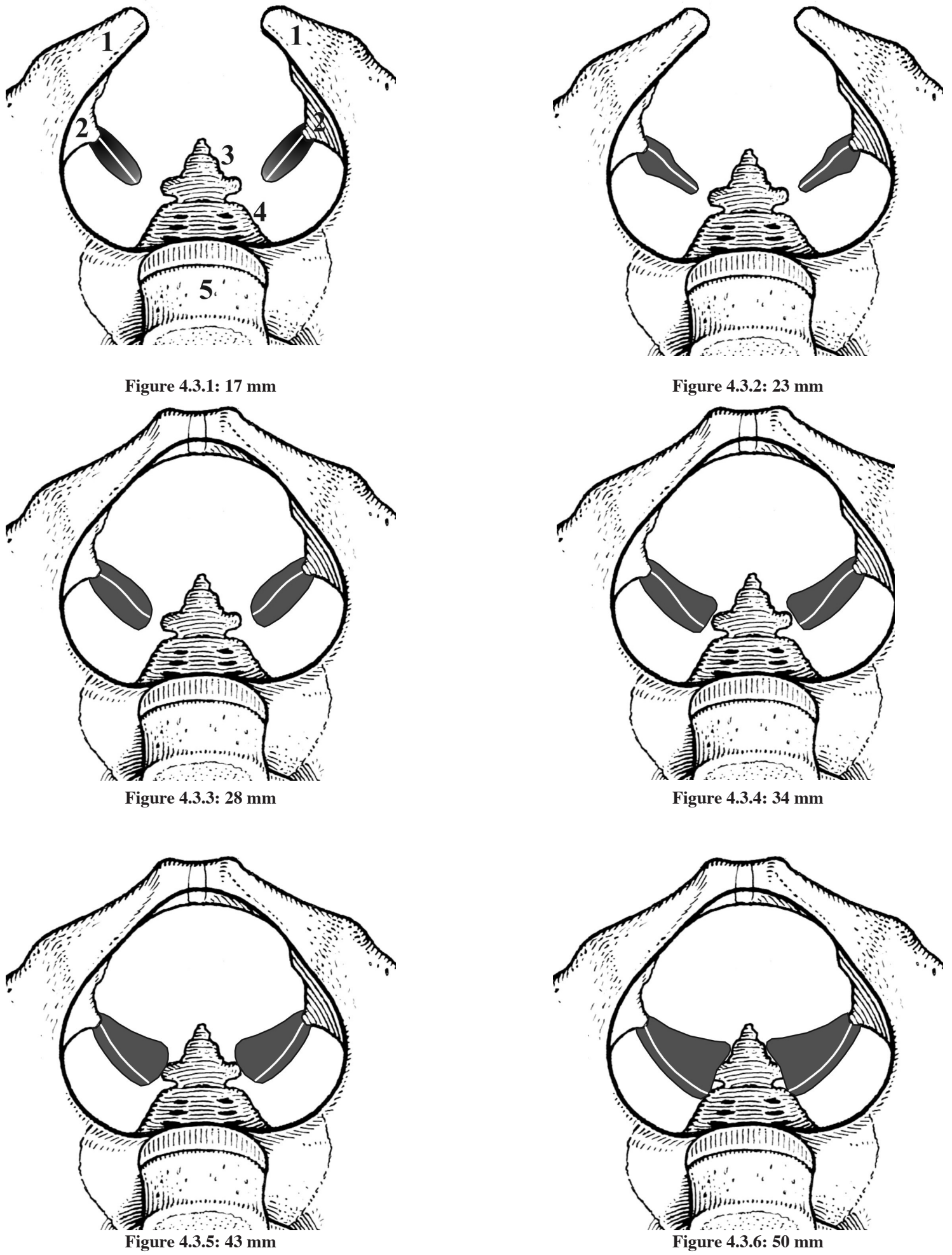

Figure 4.3.1-3.6

Schematic representation of the developing $\mathrm{m}$. coccygeus (in grey) projected on the mature bony pelvis. An artistic impression has been made for the pelvis, combining the adult bony pelvis with developing structures. In Figure 4.3.1. the muscular differentiation is represented in grey shadings with black representing differentiated muscle fibers and light grey representing mesenchyme. The combined lateral to medial and ventral to dorsal progression of the $\mathrm{m}$. coccygeus over time becomes clear.

The separation in a ventral and dorsal part of the $\mathrm{m}$. coccygeus is indicated by a white line.

$\mathbf{1}$, os pubis; $\mathbf{2}$, developing spina ischiadica; $\mathbf{3}$, os coccygis; $\mathbf{4}$, os sacrum; $\mathbf{5}$, fifth lumbar vertebra. 
in our study. Popowsky perhaps made his conclusion by taking the dorsal part as the actual $\mathrm{m}$. coccygeus, while it is in fact the ligamentum sacrospinale. The small ventral part, extending from a small band to a large muscle at the disadvantage of the dorsal part, could therefore have been mistaken for the developing $\mathrm{m}$. levatoris ani.

The $\mathrm{m}$. coccygeus is innervated by a nerve branch from the nervus pudendus. This nerve branch pierces in between the dorsal and ventral part of the muscle. Hafferl [1969] describes this innervating nerve branch lying on the pelvic aspect of the m. coccygeus. It is now shown that the branch can also be situated on the extra-pelvic aspect of the m. coccygeus.
The projection of the pelvic outlet in the embryonic and fetal stages is to the front. Because of this projection the $\mathrm{m}$. coccygeus and future ligamentum sacrospinale are projected in a cranial-caudal direction. In later fetal life, with the formation of the lumbar lordosis, the formation of the promontorium, and the backward stretching of the os coccygis, the pelvic outlet will rotate to its final position in a dorsal-caudal direction. With this rotation the $m$. coccygeus and future ligamentum sacrospinale will project in a ventral to medio-dorsal direction. 


\subsection{Clinical implications}

The early development of the human pelvic diaphragm muscles has implications for our understanding of pathophysiological conditions of the pelvic diaphragm. We give two examples:

1. The exstrophy-epispadias complex (EEC) describes a congenital malformation, with the urethra opening on the dorsum of the penis (epispadia) in conjunction with classic bladder exstrophy or cloacal exstrophy. In the spectrum of this complex a complete epispadia with bladder exstrophy is the most common variant, and is also found in females. It is associated with pubic diastasis and lateral displacement of perineal and pelvic floor muscular components, which are underdeveloped. This displacement plays a key role in the cause of urinary and fecal incontinence associated with EEC. Treatment of the incontinence in EEC patients focuses on restoration of the displacement by approximation of the lateralized perineal and pelvic floor musculature to the midline, including the pubic diastasis [de Jong 2001, De Gennaro et al 2005].

We have shown that the outgrowth of the os pubis towards the midline plays an important role in the formation of the pelvic diaphragm and especially the hiatus urogenitalis. The midline approximation of the anterior pelvic diaphragm is caused by the outgrowing os pubis, and later in fetal life also by the development of the perineal body. So, embryologically, the wish to approximate the lateralized anterior pelvic floor muscles in the treatment of EEC patients makes sense.

2. Imperforate anus is the absence of a normal anal opening. In low lesions the anus did not develop and the rectum is covered by skin. In high lesions the rectum ends in a blind pouch, usually connected to the vagina (females) or urethra (males) by a fistula. Treatment of the low lesions consists of a perineal anoplasty. The high lesions are treated by recreating a perineal opening and pulling the rectum through the newly created anus. Although much attention is given to the anal sphincter complex and levator ani, most of these treatments result in fecal incontinence [Incontinence 2005, De Gennaro et al 2005].

We have shown that the levator ani starts to develop as part of the anal sphincter complex and is attached to the deep part of the m sphincter ani externus. Recreating the anus, and pulling through of the rectum, will cause damage to the close relationship of the levator ani and the anal sphincter complex, together with neurological damage, causing failure in the physiological interaction of the two muscle groups and therefore malfunction in defecation. Recreating the anal sphincter complex by using the $\mathrm{m}$ puborectalis is bound to fail, because the $\mathrm{m}$. puborectalis does in fact not exist, as we have shown. 


\section{Samenvatting in het Nederlands}

\section{Inleiding}

De bekkenbodem is bij de mens wezenlijk anders dan bij dieren. De mens loopt rechtop, met als gevolg dat de functie van de bekkenbodem zich vooral heeft ontwikkeld ter ondersteuning van organen, terwijl de functie bij dieren voornamelijk de continentie dient. Voor deze ondersteuning heeft zich bij de mens, naast een laag voor het continentiemechanisme, een tweede laag ontwikkeld die het diaphragma pelvis wordt genoemd.

Het diaphragma pelvis heeft zich in de evolutie van de mens ontwikkeld vanuit spiergroepen die verantwoordelijk waren voor de staartbewegingen. Met het verdwijnen van de staart veranderden deze spiergroepen zich in spieren en peesbladen die ondersteuning geven aan de organen in buik en bekken.

In de anatomische literatuur is veel onenigheid over de samenstelling van de spiergroepen van het diaphragma pelvis. De belangrijkste spiergroep is de $\mathrm{m}$. levator ani, die wordt beschreven als één spier (figuur 1.2), of als een spiergroep die bestaat uit meerdere individuele spieren; $\mathrm{m}$. pubococcygeus, $\mathrm{m}$. iliococcygeus en $\mathrm{m}$. puborectalis (figuur 1.1). Verder bevindt zich in de bekkenbodem nog een spier, de $\mathrm{m}$. (ischio)coccygeus, die wisselend wel en niet tot het diaphragma pelvis wordt gerekend.

De $m$. levator ani is een spierplaat, aan de voorzijde van het kleine bekken vastgehecht aan de binnenzijde van het os pubis, aan de laterale zijde aan de arcus tendineus fasciae pelvis en aan de achterzijde aan de spina ischiadica. De $\mathrm{m}$. levator ani is zowel links als rechts gespiegeld aanwezig. De beide spieren zijn in het midden aan elkaar vastgehecht via het centrum tendineum en het ligamentum anococcygeum, en omsluiten het anale kanaal aan de achterzijde en de hiatus urogenitalis aan de voorzijde. De beide spieren sluiten de voorzijde van het kleine bekken af. De achterzijde wordt gesloten door de m. (ischio)coccygeus, die eveneens links en rechts gespiegeld aanwezig is. De hiatus urogenitalis wordt afgesloten door het urogenitale diafragma.

De m. pubococcygeus wordt beschreven als het voorste deel van de $\mathrm{m}$. levator ani, en loopt van het os pubis langs de urethra/prostaat en rectum naar het ligamentum anococcygeum en het os coccygis. In de literatuur bestaat onenigheid over het bestaan van spiervezels die zich vasthechten aan het centrum tendineum en het rectum, en over het bestaan van spiervezels die doorlopen naar de andere zijde.

De $m$. iliococcygeus loopt van de arcus tendineus levatoris ani naar het ligamentum anococcygeum en het os coccygis, alwaar zij zich vasthecht. Deze spier wordt of gezien als een deel van de $\mathrm{m}$. levator ani, dat ontspringt uit de arcus tendineus levatoris ani, of als een individuele spier. Hij toont een wisselende samenstelling van spiervezels en/of fascie. De spier vertoont geen relatie met het rectum, noch met de $\mathrm{m}$. iliococcygeus van de andere zijde.

De $m$. puborectalis wordt omschreven als bestaande uit oppervlakkige spiervezels die ontspringen ter hoogte van de symphysis pubica en het rectum omcirkelen als een soort sling; directe ingroei in de organen van het kleine bekken wordt ook beschreven.

De $m$. (ischio)coccygeus sluit de bekkenuitgang aan de achterzijde af. Deze spier loopt van de spina ischiadica naar het os coccygis en het os sacrum en heeft een nauwe relatie met het ligamentum sacrospinale. Bij de meeste volwassenen is de $m$. coccygeus geïnvolueerd tot een fascie en nauwelijks als zodanig van het ligamentum sacrospinale te onderscheiden. De spier wordt zowel beschreven als onderdeel van de $\mathrm{m}$. levator ani, of als een individuele spier.

In het kleine bekken bevindt zich nog een spier met een belangrijke rol in de bouw van het diafragma pelvis, namelijk de $m$. obturatorius in- 
ternus. Over de bekkenzijde van deze spier, gehecht aan zijn spierfascie, loopt de arcus tendineus levatoris ani, die zorgt voor de zijdelingse fixatie van de $\mathrm{m}$. levator ani. De m. obturatorius internus ontspringt rondom het foramen obturatorium en verlaat via de incisura ischiadica minor het kleine bekken om vast te hechten aan de trochanter major femoris. Deze spier zorgt voor abductie van het femur.

\section{Embryologie}

Gelet op de grote hoeveelheid publicaties, is er het laatste decennium een toenemende interesse voor functie en dysfunctie van de bekkenbodem. Over de ontwikkeling van de bekkenbodem, en die van het diaphragma pelvis in het bijzonder, is echter zo goed als niets bekend.

Popowsky beschreef in 1899 dat de $\mathrm{m}$. levator ani bestaat uit twee delen, een pars pubica en pars iliaca, en niet gescheiden kan worden van de $\mathrm{m}$. coccygeus. Hieruit concludeerde hij dat de $\mathrm{m}$. levator ani zich ontwikkelt uit spiervezels van de m. coccygeus, die dan naar voren migreren en uitwaaieren over de bekkenuitgang.

Power concludeerde in 1948 dat de m. levator ani een onderdeel is van de $\mathrm{m}$. rectus abdominis, en hiervan wordt gescheiden door ingroei van het os pubis.

Bijna honderd jaar na Popowsky schrijft Fritsch in 1994 gedetailleerder over de ontwikkeling van het diaphragma pelvis. Volgens haar is de $\mathrm{m}$. levator ani herkenbaar aan het begin van de foetale periode, in de negende week van de zwangerschap. De $\mathrm{m}$. levator ani bestaat, volgens haar, uit drie individuele spieren: de m. pubococcygeus, iliococcygeus en puborectalis. Deze spieren zijn duidelijk gescheiden van de m. coccygeus. In het tweede trimester van de zwangerschap worden oorsprong en aanhechting van elke spier duidelijk, en er treden sekse-afhankelijke verschillen op. Gedurende de hele foetale periode kunnen er geen spiervezels worden herkend die in de bekkenorganen groeien.
Over de ontwikkeling van de m. obturatorius internus is geen literatuur bekend.

\section{Het onderzoek}

Het doel van het onderzoek is meer inzicht te verkrijgen in de ontwikkeling en de samenstelling van het diaphragma pelvis. Hiervoor zijn de spieren die gerekend kunnen worden tot het diaphragma pelvis onderzocht in diverse leeftijdsstadia van humane embryo's en foetussen. In totaal zijn er 38 embryo's en foetussen met een kruin-romplengte van $9,5 \mathrm{~mm}$ tot en met $50 \mathrm{~mm}$ bestudeerd (tabel 2). De leeftijd van deze embryo's en foetussen varieert van ongeveer 40 dagen tot 12 weken zwangerschap, zijn gegroepeerd volgens de ontwikkelingsstadia van Streeter. Van vijf verschillende stadia van ontwikkeling is een driedimensionale reconstructie van het benig bekken en de spieren van het diaphragma pelvis gemaakt, om een goed inzicht te krijgen in de verhoudingen tussen de verschillende spieren. Om identificatie van de zich ontwikkelende spieren makkelijker te maken, is begonnen met de beschrijving van het jongste foetale stadium en van daaruit is terug gewerkt naar kleinere embryo's, tot het moment dat er geen spieren meer herkenbaar waren in het beschikbare materiaal.

\section{Resultaten}

\section{Musculus obturatorius internus}

De m. obturatorius internus verschijnt het eerst in embryo's met een kruin-romp-lengte van $17 \mathrm{~mm}$. In jongere embryo's is alleen diffuus mesenchyme zichtbaar. Doordat alleen materiaal met HE-kleuring beschikbaar is, is het niet mogelijk de ontwikkeling van de $\mathrm{m}$. obturatorius internus in nog jongere embryo's te vervolgen. Figuur 4.1.1-1.6 is een schematische weergave van de ontwikkeling van de $\mathrm{m}$. obturatorius internus. 
$17 \mathrm{~mm}$ ( \pm 49 dagen, stadium 18-19). Aan de binnenzijde van het os ischii, ter hoogte van de bovengrens van de ramus ossis ischii, verschijnt een condensatie van mesenchymale cellen die het bekken verlaat richting trochanter major femoris. Er is nog geen sprake van spiervezels. De membrana obturatoria heeft zich nog niet ontwikkeld. Het foramen obturatum wordt gevuld door mesenchyme.

22-23 mm ( \pm 53-54 dagen, stadium 21). De m. obturatorius internus heeft zich iets verder naar ventraal en caudaal ontwikkeld, en bereikt de meest dorsale grens van het foramen obturatum. De ontwikkeling richting femur is onveranderd, en er ontstaan nu spiervezels. De membrana obturatoria is nog niet aanwezig. Wel is een mesenchymale verdichting op deze plaats waarneembaar.

\section{8-30 mm ( \pm 58-59 dagen, stadium 23).}

Aan het einde van de embryonale periode heeft de $\mathrm{m}$. obturatorius internus zich verder ventraal en caudaal ontwikkeld langs de ondergrens van het foramen obturatum en craniaal richting het corpus ossis ischii. De spier bedekt nu de dorsale helft van het foramen obturatum, bestaat duidelijk uit spiervezels, en is omgeven door een fascie die nog niet het os pubis heeft bereikt. Het mesenchyme dat het foramen obturatum vult, begint condensatie te vertonen als eerste teken van de ontwikkeling van de membrana obturatoria.

34-35 mm ( \pm 9 weken). Aan het begin van de foetale periode heeft de $\mathrm{m}$. obturatorius internus zich verder naar ventraal-caudaal en ventraal-craniaal ontwikkeld en bedekt nu ongeveer drie kwart van het foramen obturatum. De spier heeft de regio van de toekomstige canalis obturatorius nog niet bereikt, maar de fascie heeft zich inmiddels vastgehecht aan het os pubis. De membrana obturatoria is nu duidelijk herkenbaar, maar bestaat rondom de nervus obturatorius nog uit mesenchyme.
42-43 mm ( \pm 10 weken). De $\mathrm{m}$. obturatorius internus bedekt nu meer dan drie kwart van het foramen obturatum, maar bereikt zelf de ramus superior ossis pubis nog niet. De membrana obturatoria begint zich nu ook duidelijk te ontwikkelen rondom de nervus obturatorius; de canalis obturatorius begint zich te vormen.

$50 \mathrm{~mm}$ ( \pm 12 weken). In de twaalfde week van de zwangerschap heeft de $\mathrm{m}$. obturatorius internus zich bijna volledig ontwikkeld, uitgezonderd een klein randje ter hoogte van de ventrale en caudale rand van het foramen obturatum. De spier strekt zich naar dorsaal uit en verlaat het bekken om zich vast te hechten aan de trochanter major femoris. De membrana obturatoria en de canalis obturatorius zijn volledig ontwikkeld.

Uit de beschreven ontwikkeling kan het volgende worden geconcludeerd:

1. De m. obturatorius internus ontwikkelt zich van dorsaal naar ventraal. Feitelijk betekent dit dat de begrenzing van het foramen obturatum niet de oorsprong maar de aanhechting van de $\mathrm{m}$. obturatorius is. De huidige anatomische beschrijving van de trochanter major femoris als aanhechting is dus, uit oogpunt van ontwikkeling, niet juist.

2. Met de uitgroei van de m. obturatorius internus ontwikkelt zich ook de membrana obturatoria: er is klaarblijkelijk een wisselwerking tussen spier en membraan. De ontwikkeling van de spier initieert de ontwikkeling van de membrana obturatoria, die vervolgens richting geeft aan de ontwikkeling van de $\mathrm{m}$. obturatorius internus. Een andere spier, de m. obturatorius externus, die al eerder tegen het membraan aanligt, doet dit niet.

3. Toekomstig wetenschappelijk onderzoek moet uitwijzen of de m. obturatorius internus ontstaat uit een mesenchyme kern ter hoogte van de incisura ischiadica minor, ter hoogte van de trochanter major femoris, of uit een combinatie van beide. 
Musculus levator ani

Net als de m. obturatorius internus is ook de ontwikkelende $\mathrm{m}$. levator ani pas herkenbaar bij embryo's met een kruin-romp-lengte van $17 \mathrm{~mm}$. Figuur 4.2.1-2.6 is een schematische weergave van de ontwikkeling van de $\mathrm{m}$. levator ani.

$17 \mathrm{~mm}$ ( \pm 49 dagen, stadium 18-19). De $\mathrm{m}$. levator ani verschijnt ter hoogte van het anale sphincter complex als één spier, vastgehecht aan het diepe deel van de m. sphincter ani externus. De levator ani strekt zich naar ventraal uit richting het os pubis en is niet gefixeerd aan de sinus urogenitalis. In de richting van het os pubis neemt de differentiatie van de spier af. Mediaal van het zich ontwikkelende os pubis eindigt de spier als mesenchyme. Hetzelfde gebeurt in dorsale richting, naar het os coccygis. Daar eindigt de $\mathrm{m}$. levator ani als mesenchyme ter hoogte van het zich ontwikkelende ligamentum anococcygeum. De spier zelf is nog maar een smalle band. De fascie van de $\mathrm{m}$. levator ani is zichtbaar als een laag van mesenchyme rondom de spier en strekt zich verder uit richting de toekomstige arcus tendineus levatoris ani. Linker en rechter os pubis bereiken het mid-sagittale vlak niet.

22-23 mm ( \pm 53-54 dagen, stadium 21). De $\mathrm{m}$. levator ani bestaat nu volledig uit spiervezels die ventraal eindigen in de zich ontwikkelende fascia endopelvica. $\mathrm{Er}$ is geen directe fixatie aan het os pubis, dat de 'midline' nog niet heeft bereikt, maar zich inmiddels wel uitstrekt tot het niveau van de levator ani. Er is nog geen uitbreiding naar mediaal, maar naar lateraal begint de spier zich uit te strekken richting het ventrale deel van de toekomstige arcus tendineus levatoris ani. Hierbij volgt het de eigen fascie die zich reeds in het mesenchyme heeft gevormd.

28-30 mm ( \pm 58-59 dagen, stadium 23). Aan het einde van de embryonale periode treedt een versnelling op in de ontwikkeling van de $\mathrm{m}$. levator ani. Linker en rechter os pubis hebben het midsagitale vlak bereikt en de symphysis pubica gevormd. Hiermee heeft de spier zich naar mediaal ontwikkeld en omsluit nu de sinus urogenitalis. Naar lateraal heeft hij zich ontwikkeld tot ongeveer halverwege de $\mathrm{m}$. obturatorius internus, langs de arcus tendineus levatoris ani. Aan de dorsale zijde heeft de levator ani zich verder ontwikkeld, richting os coccygis, en hecht zich aan het ontwikkelende ligamentum anococcygeum.

34-35 mm ( \pm 9 weken). Aan het begin van de foetale periode vertoont de $\mathrm{m}$. levator ani weinig progressie. Aan de ventrale zijde heeft de spier zich verder ontwikkeld richting het os pubis, samen met de verder ontwikkelde fascia endopelvica. Tussen de sinus urogenitalis en het rectum heeft de $\mathrm{m}$. levator ani zich eveneens verder ontwikkeld naar mediaal. Er ontstaat nu duidelijk een hiatus urogenitalis en een hiatus ani. De m. levator ani is nog steeds één spier.

42-43 mm ( \pm 10 weken). Eén week later vertoont de $\mathrm{m}$. levator ani weer een sterke progressie in de ontwikkeling, voornamelijk lateraal en dorsaal. Dorsaal bereikt de spier bijna het os coccygis en lateraal heeft het, de arcus tendineus levatoris ani volgend, de toekomstige spina ischiadica bijna bereikt.

$50 \mathrm{~mm}$ ( \pm 12 weken). De levator ani heeft zich naar mediaal verder ontwikkeld tussen de sinus urogenitalis en het rectum, als gevolg van het zich ontwikkelende centrum tendineum, alsmede dorsaal door het zich ontwikkelende ligamentum anococcygeum. Ventraal hecht de $\mathrm{m}$. levator ani zich aan het os pubis, lateraal volgt zij de arcus tendineus levatoris ani tot aan de toekomstige spina ischiadica en dorsaal bereikt zij de laterale rand van het os coccygis. Met uitzondering van het gebied ter hoogte van het centrum tendineum heeft de levator ani nu min of meer de volwassen configuratie bereikt. De $\mathrm{m}$. levator ani is één spier, omgeven door een eigen fascie. 
Uit de beschreven ontwikkeling kan het volgende worden geconcludeerd:

De $\mathrm{m}$. levator ani is één spier. $\mathrm{Er}$ is geen embryologische grond voor een onderverdeling in aparte spieren, hoogstens fictief op basis van de plaats van aanhechting. Het bestaan van een $\mathrm{m}$. puborectalis, of puborectale sling, is embryologisch niet mogelijk aangezien er links noch rechts spiervezels van de levator ani oversteken naar de contralaterale zijde. De beschrijving van de ontwikkeling zoals door Fritsch gegeven kan in zijn geheel niet worden ondersteund.

- $\quad$ De m. levator ani ontstaat ter hoogte van het anale sphincter complex en groeit als een smalle band naar ventraal en dorsaal, om zich vervolgens van ventraal naar lateraal en dorsaal uit te spreiden over de bekkenuitgang als een 'pauw die zijn staartveren spreidt'. De ontwikkeling is dus van ventraal naar dorsaal, in tegenstelling tot de beschrijving van Popowsky, die uitgaat van een ontwikkeling van dorsaal naar ventraal.

- $\quad$ Ten gevolge van de ontwikkeling van het os pubis naar mediaal omsluit de levator ani de sinus urogenitalis, maar is niet gefixeerd aan de urogenitale organen. De ontwikkeling van de symphysis pubica is waarschijnlijk de basis voor Power's theorie over de ontwikkeling van het diaphragma pelvis.

- $\quad$ Er bestaan geen sekse-afhankelijke verschillen in de ontwikkeling van het diaphragma pelvis.

- $\quad$ Mediale sluiting van de bekkenuitgang door de linker en rechter $\mathrm{mm}$. levatores ani ontstaat door de ontwikkeling van het os pubis ventraal, door de ontwikkeling van het centrum tendineum mediaal en door ontwikkeling van het ligamentum anococcygeum dorsaal.

- $\quad$ Het diaphragma pelvis ontwikkelt zich in een naar ventraal geprojecteerde bekkenuitgang. Met het ontstaan van promontorium, en lumbale lordose, en met het strekken van het os coccygis, roteert de bekkenuitgang naar een dorsocaudale richting, zoals bij volwassenen. In de beschreven embryo's is het os coccygis het laagste punt van het bekken, en in de volwassen situatie is dat het os pubis.

\section{Musculus (ischio)coccygeus}

Net als de m. obturatorius internus en de $\mathrm{m}$. levator ani is ook de zich ontwikkelende $\mathrm{m}$. coccygeus pas herkenbaar bij embryo's met een kruin-romp-lengte van $17 \mathrm{~mm}$. In figuur 4.3.1-3.6 is een schematische weergave gegeven van de ontwikkeling van de $\mathrm{m}$. coccygeus.

$17 \mathrm{~mm}( \pm 49$ dagen, stadium 18-19). Net boven het niveau waar de $\mathrm{m}$. obturatorius internus het bekken verlaat verschijnt de $\mathrm{m}$. coccygeus en vertoont zij reeds spiervezels. De spina ischiadica is nog niet aanwezig. De m. coccygeus kan worden vervolgd richting os coccygis, waarbij de differentiatie verdwijnt en clustering van mesenchyme cellen optreedt. De spier blijkt te bestaan uit een ventraal en dorsaal deel.

\section{2-23 mm ( \pm 53-54 dagen, stadium 21).} De m. coccygeus bestaat nu volledig uit spierweefsel en heeft zich verder uitgestrekt richting os coccygis. Lateraal is de voorachterwaartse diameter groter dan mediaal. De spier bestaat uit een ventraal deel dat richting het os coccygis loopt en een groter dorsaal deel dat richting het os sacrum loopt.

28-30 mm ( \pm 58-59 dagen, stadium 23). De voorachterwaartse diameter van de $\mathrm{m}$. coccygeus is nu ook mediaal richting het os coccygis toegenomen. Het ventrale deel van de spier is groter geworden, maar blijft kleiner dan het dorsale deel.

34-35 mm ( \pm 9 weken). Aan het begin van de foetale periode begint de toekomstige spina ischiadica zich te vormen als clustering van mesenchymale cellen. De voorachterwaartse diameter van de $\mathrm{m}$. coccygeus is iets toegenomen. $\mathrm{Er}$ is een verschuiving opgetreden in de diameter van het ventrale en dorsale deel van de spier. 
Ter hoogte van de toekomstige spina ischiadica is het dorsale deel groter dan het ventrale deel en ter hoogte van het os coccygis is dit precies andersom.

42-43 mm ( \pm 10 weken). De voorachterwaartse diameter van de $\mathrm{m}$. coccygeus is onveranderd. De spier heeft zich wel verder ontwikkeld richting het os coccygis. Het ventrale deel van de spier is nu het grootste deel van de m. coccygeus geworden.

$50 \mathrm{~mm}$ ( \pm 12 weken). De m. coccygeus heeft zich nu ontwikkeld tot een omvang vergelijkbaar met de volwassen bekkenbodem, met uitzondering van de aanhechtingen aan het os coccygis en het os sacrum. De toekomstige spina ischiadica is aanwezig in de vorm van kraakbeen. Het ventrale deel van de spier waaiert uit naar het os coccygis. Het dorsale deel kan worden vervolgd tot aan de laterale zijde van het os sacrum, waar het zich via bindweefsel vasthecht. Het ventrale en dorsale deel blijven aan elkaar gefixeerd.
Uit de beschreven ontwikkeling kan het volgende worden geconcludeerd:

De m. coccygeus ontstaat ter hoogte van de toekomstige spina ischiadica en ontwikkelt zich richting het os coccygis.

- $\quad$ De m. coccygeus bestaat uit en ventraal en een dorsaal deel; het ventrale deel is de feitelijke m. coccygeus en het dorsale deel is het toekomstige ligamentum sacrospinale. In de beschreven embryo's en foetussen bestaan beide delen uit spierweefsel. Bij volwassenen zijn beide delen, maar in ieder geval het dorsale deel, veranderd in bindweefsel. Het moment waarop dit gebeurt kan onderwerp zijn van toekomstig onderzoek.

- $\quad$ Het onderscheid in een ventraal en dorsaal deel verklaart waarschijnlijk de theorie van Popowsky, die beschrijft dat de $\mathrm{m}$. levator ani zich ontwikkelt uit het ventrale deel van de m. coccygeus. Hij heeft waarschijnlijk het groter wordende ventrale deel van de $\mathrm{m}$. coccygeus aangezien voor de $\mathrm{m}$. levator ani, en het kleiner wordende dorsale deel als $m$. coccygeus. 


\section{REFERENCES}

Abitbol MM. (1988). Evolution of the ischial spine and of the pelvic floor in the Hominoidea. Am J Phys Antropol; 75:5367.

Abitbol MM. (1989). Sacral curvature and supine posture. Am J Phys Anthropol; 80:379-389.

Abrams P, Cardozo L, Khoury S, Wein A (eds). (2005). Incontinence-3rd International Consultation on Incontinence. Third Ed., Vol 1 \& 2. Paris: Health Publications Ltd.

Barber MD, Bremer RE, Thor KB, Dolber PC, Kuehl TJ, Coates KW. (2002). Innervation of the female levator ani muscles. Am J Obstet Gynecol; 187:64-71.

Barnes, AR. (1921). The pelvic fascia. Anat Rec; 22:37-55.

Barbaric ZL, Marumoto AK, Raz S. (2001). Magnetic resonance imaging of the perineum and pelvic floor. Top Magn Reson Imaging; 12:83-92.

Bitoh Y, Shimotake T, Sasaki Y, Iwai N. (2002). Development of the pelvic floor muscles of murine embryos with anorectal malformations. J Pediatr Surg; 37:224-227.

Blok S de. (1982). The connective tissue of the adult female pelvic region. Acta Morphol Neerl-Scand; 20:65-92.

Blok S de. (1982). Spatial architecture of musculo-fibrous tissue in the female pelvic region. Thesis: Amsterdam University.

Bogduk N. (1996). Issues in anatomy: the external anal sphincter revisited. Aust N-Z J Surg; 66:626-629.

Bryce TH. (1923). In: Quain's, Elements of Anatomy. First Ed, Vol 4, Pt 2. London: Longmans, Green and Co. pp 205-218

Caro R De. (1998). Morphometric analysis of the fibroadipose tissue of the female pelvis. J Urol; 160:707-713.

Cotran RS. (1999) In: Robbins, Pathologic basis of disease. Sixth Ed. Philadelphia: W.B. Saunders \& Co. pp 173-174.

Chandebois R, Faber J. (1983). Automation in animal development. A new theory derived from the concept of cell sociology. Monograph Dev Biol; 16:1-202.

Davies JW. (1955). Man's assumption of the erect posture: its effect on the position of the pelvis. Am J Obstet Gynaecol; 97:1012-1020.

DeLancey J. (1994). Functional anatomy of the pelvic floor and urinary continence mechanism. In: Pelvic floor re-education. Principles and practice. New York: Springer Verlag. pp 9-21.

Delbet P. (1907). Vessie, urèthre, prostate, verge, périnée. In: Poirier \& Charpy, Traité d’Anatomie humaine. Vol 5, Pt 1. Paris: Masson. pp 74-240.

Derry DE. (1907). On the real nature of the so-called pelvic fascia. J Anat Physiol; 42:95-106.

Dickinson RL (1889). Studies of the levator ani muscle. Am J Obstet; 22:897-917.

Dorschner W, Stolzenburg JU, Neuhaus J. (2001). Structure and function of the bladder neck. Adv Anat Embr Cell Biol; Vol 159.

Elftman, HO. (1932). The evolution of the pelvic floor of primates. Am J Anat; 51:307-346.

Fritsch H, Kühnel W. (1992a). Development and distribution of adipose tissue in the human pelvis. Early Hum Dev; 28:79-88. 
Fritsch, H. (1992b). The connective tissue sheath of uterus and vagina in the human female fetus. Ann Anat; 174:261-266.

Fritsch, H. (1993). Development and organization of the pelvic connective tissue in the human fetus. Ann Anat; 175:531539.

Fritsch H, Fröhlich B. (1994a). Development of the levator ani muscle in human fetuses. Early Hum Dev; 37:15-25.

Fritsch, H (1994b). Topography and subdivision of the pelvic connective tissue in human fetuses and in the adult. Surg Radiol Anat; 16:259-265.

Fritsch, H; Hotzinger, H. (1995). Tomographical anatomy of the pelvis, visceral pelvic connective tissue and its compartments. Clin Anat; 8(1):17-24.

Fucini C, Elbetti C, Messerini L. (1999). Anatomic plane of separation between external anal sphincter and puborectalis muscle. Clinical implications. Dis Colon Rectum; 42(3):374-379.

Gardner ED, Gray DJ, O’Rahilly R. (1986).Anatomy. A regional study of human structure. Fifth Ed. New York, NY: W.B. Saunders \& Co. pp 499-501.

Gegenbauer C. (1903). Lehrbuch der Anatomie des Menschen. Seventh Ed, Vol 2. Leipzig: W. Engelman. pp 93-200.

Gennaro M de, Mosiello G. (2005). The pelvic floor-Congenital anomalies from children to adults. Trieste: Edizioni Goliardiche.

Gray H, Williams PL (1995). Gray's Anatomy. The anatomical basis of medicine and surgery. Thirty-eighth Ed. Edinburgh-New York: Churchill \& Livingston.

Gribnau AAM, Geijsberts LGM. (1981). Developmental stages in the Rhesus monkey (Macaca mulatta). Adv Anat Embr Cell Biol; Vol 68

Haderer, JM, Pannu HK, Genadry R, Hutchins GM. (2002). Controversies in female urethral anatomy and their significance for understanding urinary incontinence: observations and literature overview. Int Urogynecol J Pelvic Floor Dysfunct; 13(4):236-252.

Hafferl, A. (1969). Lehrbuch der topografischen Anatomie. New York: Springer Verlag.

Hamilton WJ, Boyd JD, Mossman HW. (1966). Human Embryology: Prenatal development of form and function. Cambridge: Heffer.

Havenga, K. (1998). Total mesorectal excision in rectal cancer surgery. Thesis: Leiden University.

Hjartardottir S, Nilsson J, Petersen C, Lingman G. (1997). The female pelvic floor: A dome - not a basin. Acta Obstet Gyneacol Scand; 76:567-571.

Holl, M. (1897). Die Muskeln und Fascien des Beckenausganges. In: Von Bardeleben (ed), Handbuch der Anatomie, Vol 7, Pt 4. Jena: Teubner Verlag.

Holl, M. (1894). Zur Homologie der Muskeln des Diaphragma pelvis. Anat Anz; 10:395-400.

Jong de, TPVM. (2001). Surgical aspects of pediatric urinary incontinence.Thesis: Utrecht University.

Klutke CG, Siegel CL. (1995). Functional female pelvic anatomy. Urol Clin North Am; 22:487-497.

Knauer S. (1914). Ursachen und Folgen des aufrechten Ganges des Menschen. Anat Hefte; 22(2):138-141.

Lawson JON. (1974). Pelvic anatomy. (I) Pelvic floor muscles. Ann R Coll Surg Eng; 54:244-252. 
Lawson, JON. (1974). Pelvic anatomy. (II) Anal canal and associated sphincters. Ann R Coll Surg Eng; 54:288-300.

Levi AC, Borghi F, Garavoglia M. (1991). Development of the anal canal muscles. Dis Colon Rectum; 34(3):262-266.

Marani E, Pijl ME, Kraan MC, Lycklama a Nijeholt GA, Videleer AC. (1993). Interconnections of the upper ventral rami of the human sacral plexus: a reappraisal for dorsal rhizotomy in neurostimulation operations. Neurourol Urodyn; 12(6):585-98.

Marani, E. (2002). The pelvis: another view. Enschede: Twente University Press.

Meyer GH. (1861). Lehrbuch der Anatomie des Menschen. Leipzig: Engelmann.

Miller, A. (1996). In: Emery and Rimoin, eds. Principle and practice of medical genetics. Third edition. New York: Churchill \& Livingston. pp 245-246

Mostwin, LM. (1991). Current concepts of female pelvic anatomy and physiology. Urol Clin North Am; 18(2):175-195.

Occelli B, Narducci F, Hautefeuille J. (2001). Anatomic study of arcus tendineus fasciae pelvis. Eur J Obstet Gynecol Reprod Biol; 97(2):213-9.

Olsen AL, Rao SS. (2001). Clinical neurophysiology and electrodiagnostic testing of the pelvic floor. Gastroenterol Clin North Am; 30(1):33-54, v-vi.

O'Rahilly, R. (1979). Early human development and the chief sources of information on staged human embryos. Eur J Obstet Gynaecol Reprod Biol; 9(4):273-280.

Piersol, A. (1930). Human Anatomy. Ninth Edition. Philadelphia: Lippincott. pp 557-562.

Pit MJ, de Ruiter MC, Lycklama A Nijeholt AA, Marani E, Zwartendijk J. (2003). Anatomy of the arcus tendineus fasciae pelvis in females. Clin Anat; 16(2):131-137.

Popowsky J. (1899). Zur Entwicklungsgeschichte der Dammuskulatur beim Menschen. Anat Hefte, Abt. 1; 12(38):13-48.

Power J. (1948). Embryological development of the levator ani muscle. Am J Obstet Gynaecol; 55(3):367-381.

Putte SCJ van der. (2005). The development of the perineum in the human. Adv Anat Embr Cell Biol; Vol 177.

Quain J. (1899). Elements of Anatomy. Vol 2, Pt 2. London: Longman, Green, and Co. pp 343-344

Shafik, A. (1975). A new concept of the anatomy of the anal sphincter mechanism and the physiology of defecation. II. Anatomy of the levator ani muscle with special reference to the puborectalis. Invest Urol; 13:175-182.

Thompson P. (1899). The myology of the pelvic floor. A contribution to human and comparative anatomy. London: McCorquodale \& Co.

Vesalius, A. (1543 and 1555). De Humani Corporis Fabrica, Libri Septem. Apud Basileae Oporinus.

Waldeyer, W. (1899). Das Becken. Bonn: Friedrich Cohen. pp 209-211

Zacharin, RF. (1985). Pelvic floor anatomy and the surgery of pulsion enterocele. New York: Springer Verlag. pp 31-38. 


\section{PART Five}

\section{Full Color Illustrations}




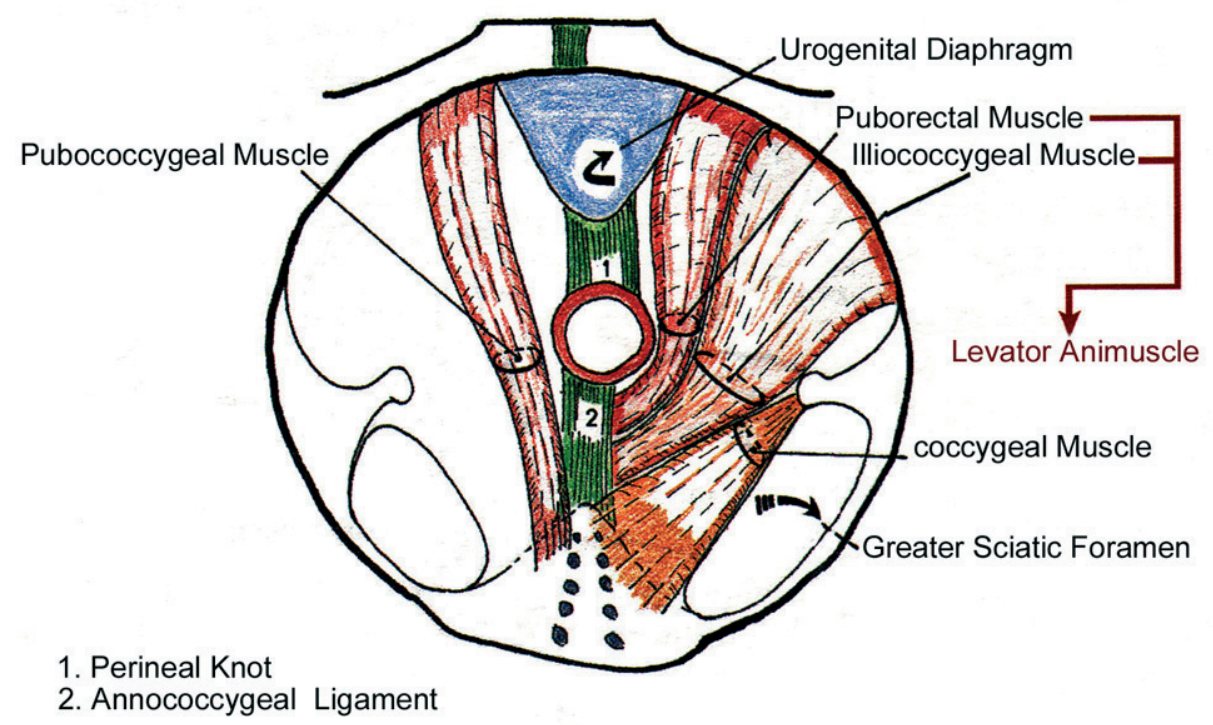

Figure 1.1

Schematic representation of the muscles of the pelvic diaphragm, as separate muscles. From Marani [2002], with permission.

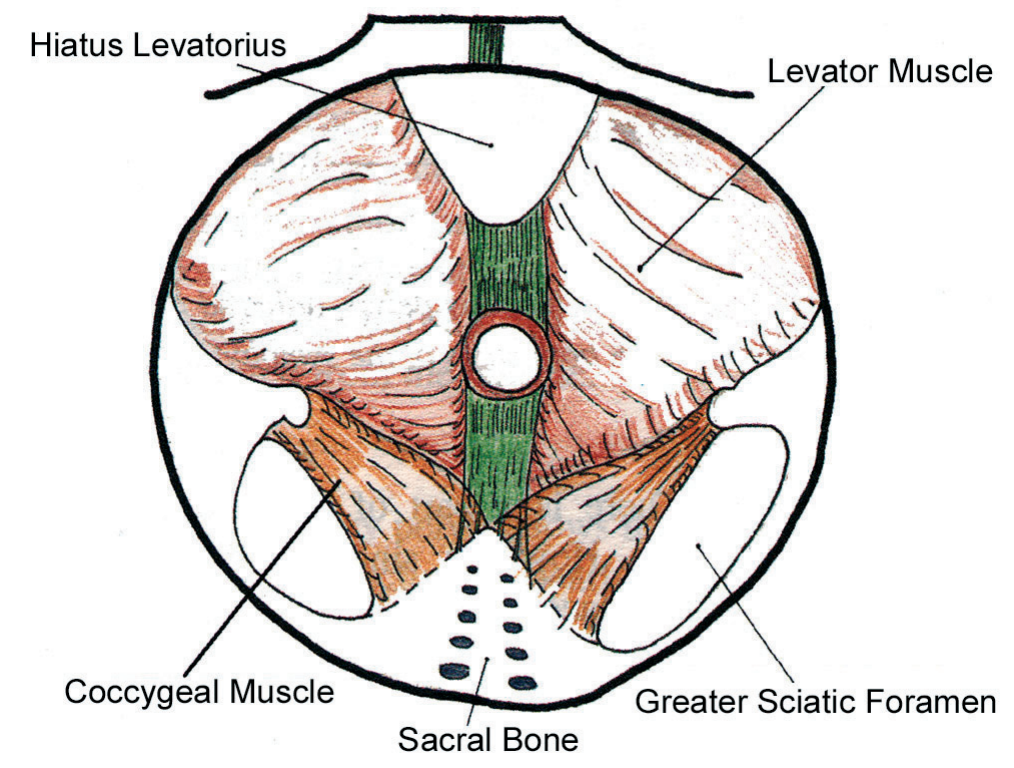

Figure 1.2

Schematic representation of the muscles of the pelvic diaphragm, as one single muscle. From Marani [2002], with permission. 


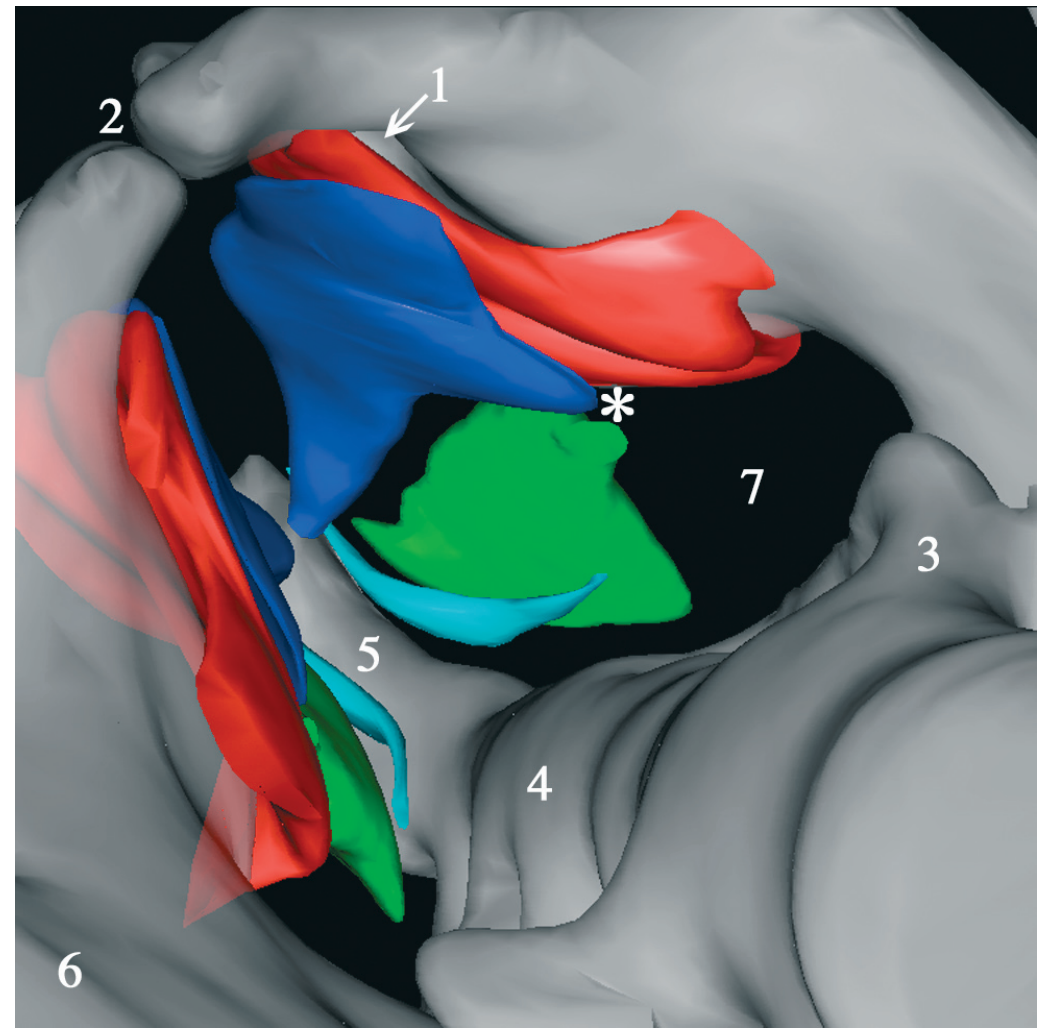

Figure 50mm.10

View from above, on the pelvic diaphragm.

$\mathbf{1}$, canalis obturatorius; $\mathbf{2}$, symphysis pubica; $\mathbf{3}$, pars lateralis ; $\mathbf{4}$, os sacrum; $\mathbf{5}$, os coccygis; $\mathbf{6}$, os ilium; $\mathbf{7}$, foramen ischiadicum majus; *, future spina ischiadica; red, $\mathrm{m}$. obturatorius internus; blue, $\mathrm{m}$. levator ani; green, m. coccygeus; light blue, $\mathrm{m}$. sacrococcygeus ventralis.

For illustrative purposes the pelvic viscera (sinus urogenitalis and rectum) have been left out. The $\mathrm{m}$. levator ani closes the ventral half of the pelvic outlet. Ventral to dorsal it is completely covering the $\mathrm{m}$. obturatorius internus. The $\mathrm{m}$. coccygeus closes the dorsal half of the pelvic outlet and has the same size as the $\mathrm{m}$. levator ani.

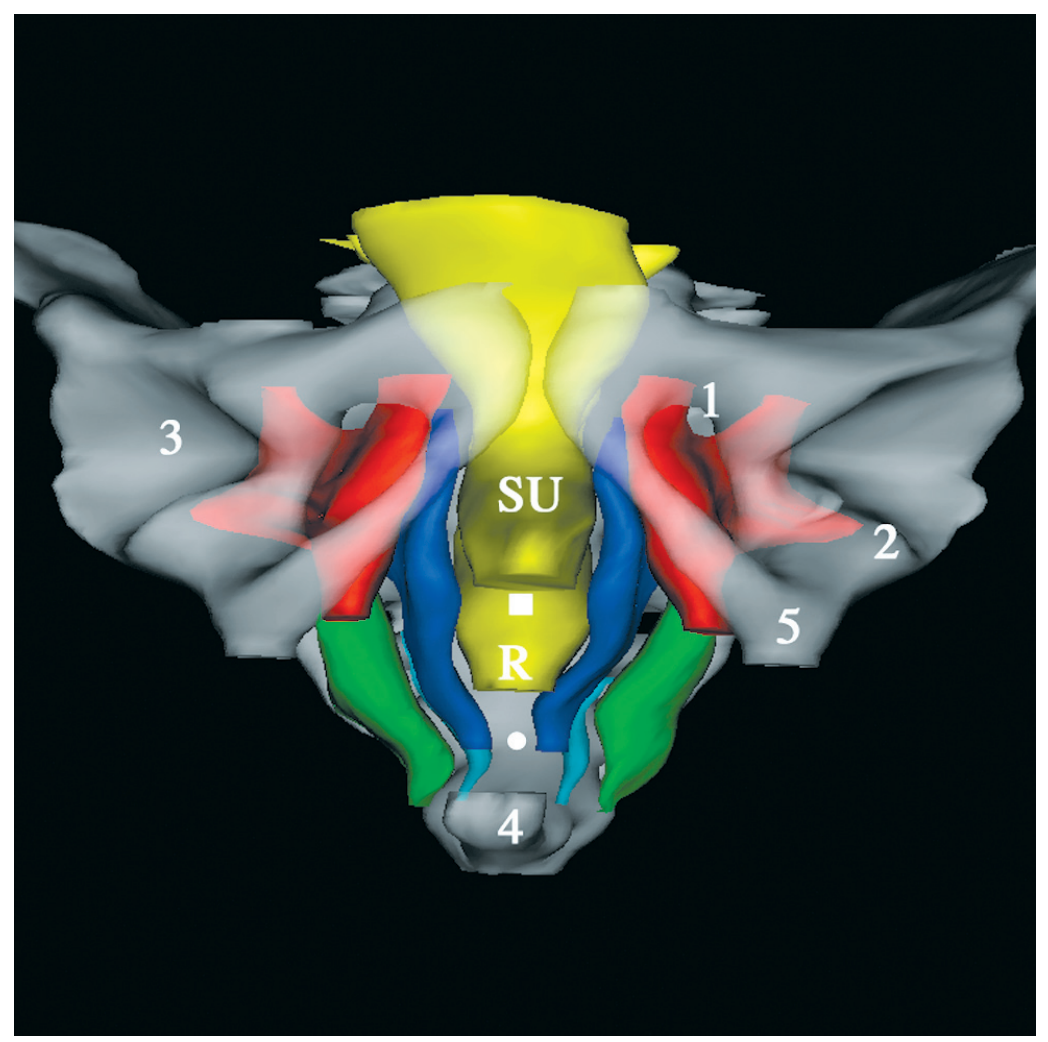

Figure 50mm.11

Frontal view of the pelvic diaphragm.

$\mathbf{1}$, canalis obturatorius; $\mathbf{2}, \mathrm{m}$. obturatorius internus leaving pelvis to insert on femur; $\mathbf{3}$, acetabulum; $\mathbf{4}$, os coccygis; $\mathbf{5}$, ramus ossis ischii; SU, sinus urogenitalis; R, rectum; red, $\mathrm{m}$. obturatorius internus; blue, $\mathrm{m}$. levator ani; green, $\mathrm{m}$. coccygeus; light blue, $\mathrm{m}$. sacro-coccygeus ventralis.

The $\mathrm{m}$. obturatorius internus completely covers the foramen obturatum except for the canalis obturatorius. Note the lateral position of the $\mathrm{m}$. coccygeus in regard to the $\mathrm{m}$. levator ani. The left and right $\mathrm{mm}$. levatores ani show curving around the sinus urogenitalis and rectum nearing each other at the level of the future centrum tendineum (white square) and ligamentum anococcygeum (white dot). 


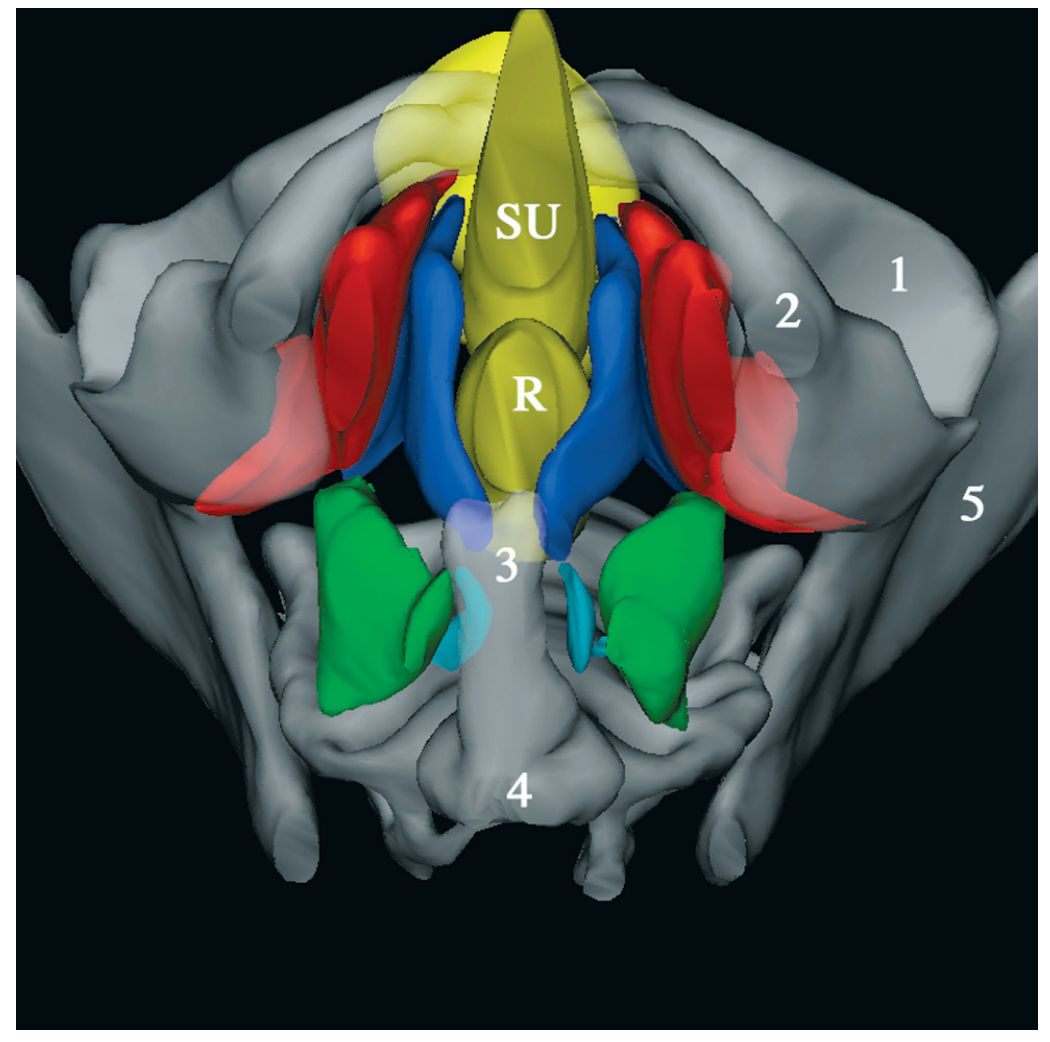

Figure 50mm.12

View of the pelvic diaphragm from below.

$\mathbf{1}$, acetabulum; $\mathbf{2}$, ramus ossis ischii; $\mathbf{3}$, os

coccygis; $\mathbf{4}$, last sacral vertebra; $\mathbf{5}$, os ilium;

SU, sinus urogenitalis; $\mathbf{R}$, rectum; red, m. obturatorius internus; blue, $\mathrm{m}$. levator ani; green, $\mathrm{m}$. coccygeus; light blue, $\mathrm{m}$. sacrococcygeus ventralis.

Note the 'four quadrant' formation of the pelvic diaphragm.

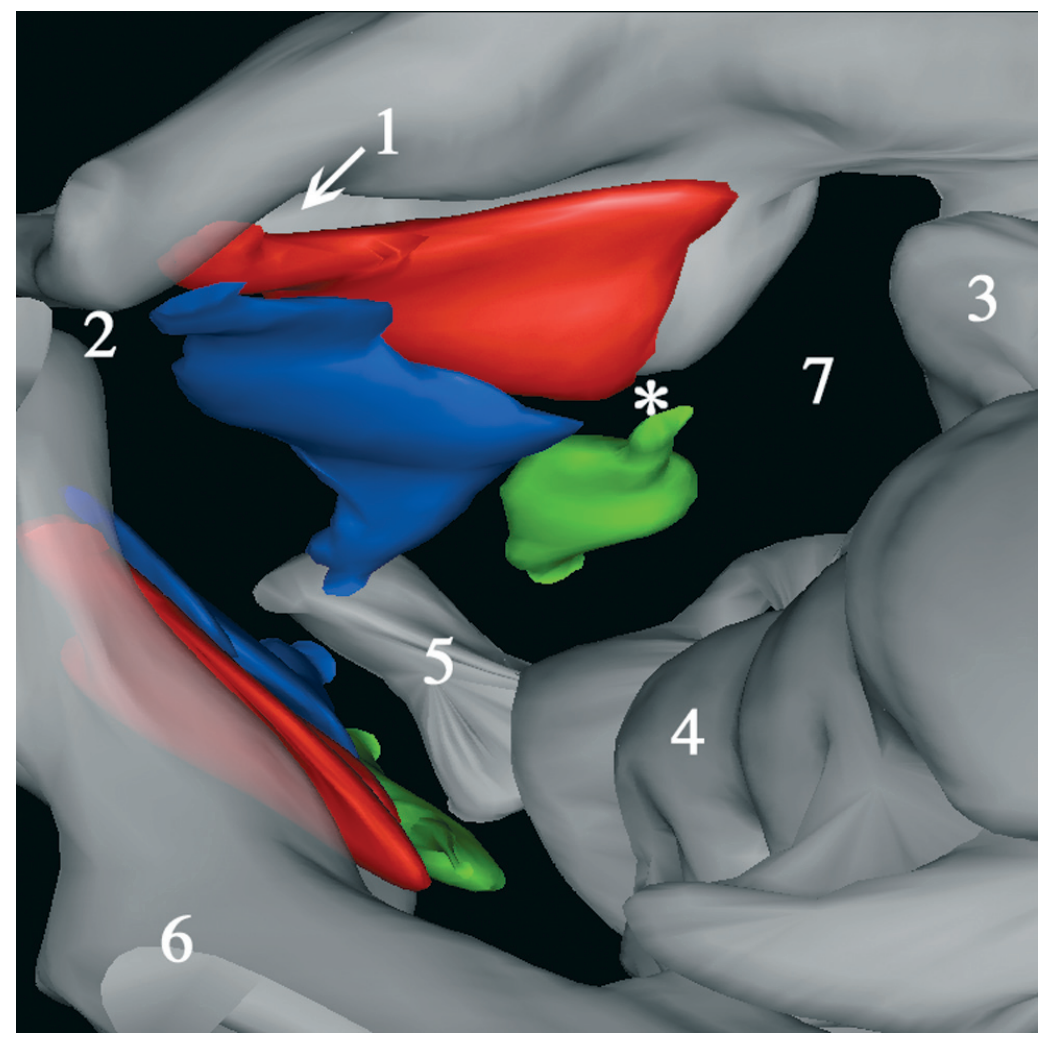

Figure 43mm.7

View from above, on the pelvic diaphragm.

$\mathbf{1}$, canalis obturatorius; $\mathbf{2}$, symphysis pubica;

$\mathbf{3}$, articulatio sacroiliaca; $\mathbf{4}$, os sacrum; $\mathbf{5}$, os

coccygis; $\mathbf{6}$, os ilium; $\mathbf{7}$, foramen ischiadicum majus; *, future spina ischiadica; red, m. obturatorius internus; blue, $\mathrm{m}$. levator ani; green, $\mathrm{m}$. coccygeus.

For illustrative purposes the pelvic viscera (sinus urogenitalis and rectum) have been left out. The $\mathrm{m}$. levator ani closes the ventral half of the pelvic outlet and is almost completely covering the $\mathrm{m}$. obturatorius internus. Comparing to the $50 \mathrm{~mm}$ fetus the $\mathrm{m}$. levator ani does not extent as far dorsally. The m. coccygeus closes the dorsal half of the pelvic outlet. 


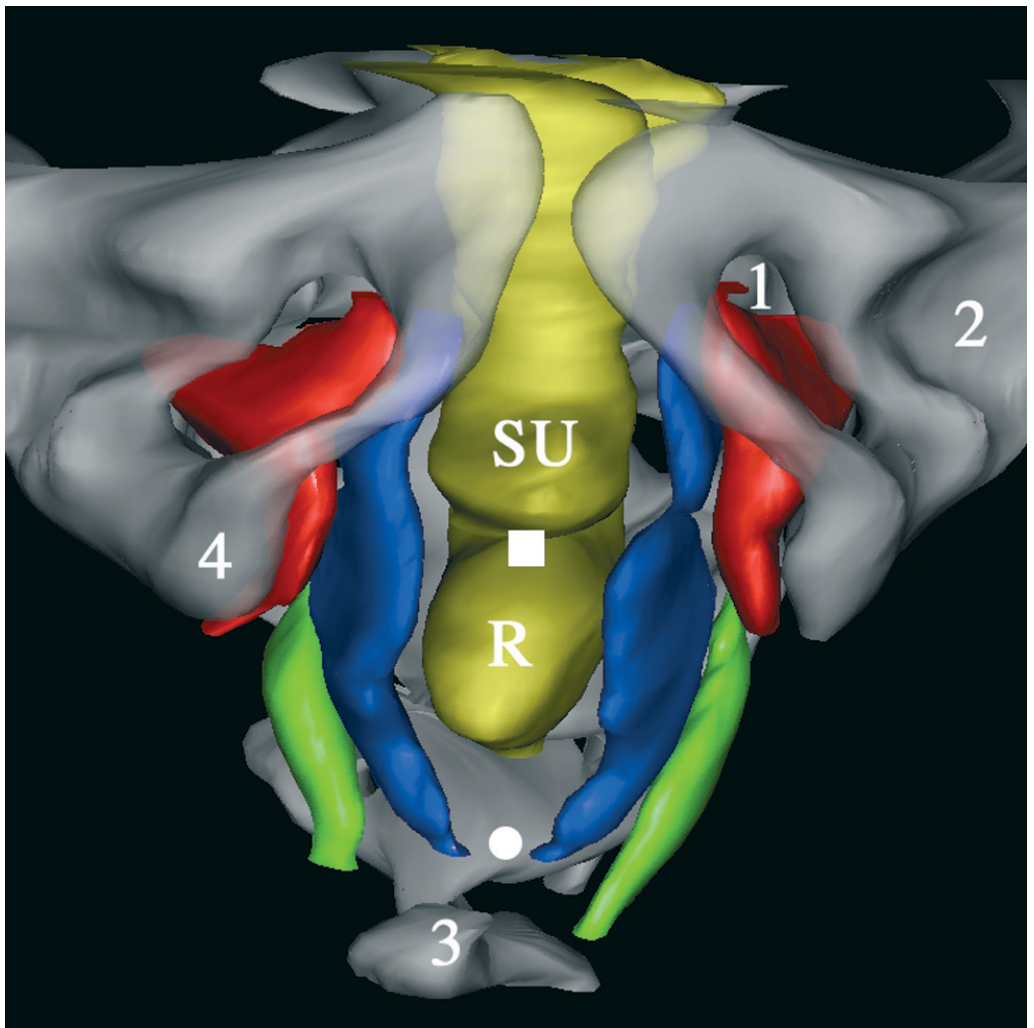

Figure $43 \mathrm{~mm} .8$

Frontal view of the pelvic diaphragm.

$\mathbf{R}$, rectum; $\mathbf{S U}$, sinus urogenitalis; $\mathbf{1}$, canalis obturatorius; 2, acetabulum; 3, os coccygis; $\mathbf{4}$, ramus ossis ischii; white square, future centrum tendineum; white dot, future ligamentum anococcygeum; red, m. obturatorius internus; blue, $\mathrm{m}$. levator ani; green, $\mathrm{m}$. coccygeus.

The $\mathrm{m}$. obturatorius internus does not completely cover the foramen obturatum. It is not present near the canalis obturatorius. The left and right $\mathrm{mm}$. levatores ani show curving around the sinus urogenitalis and rectum at the level of the future centrum tendineum and ligamentum anococcygeum. Extension towards the midline is not as advanced as in the $50 \mathrm{~mm}$ fetus.

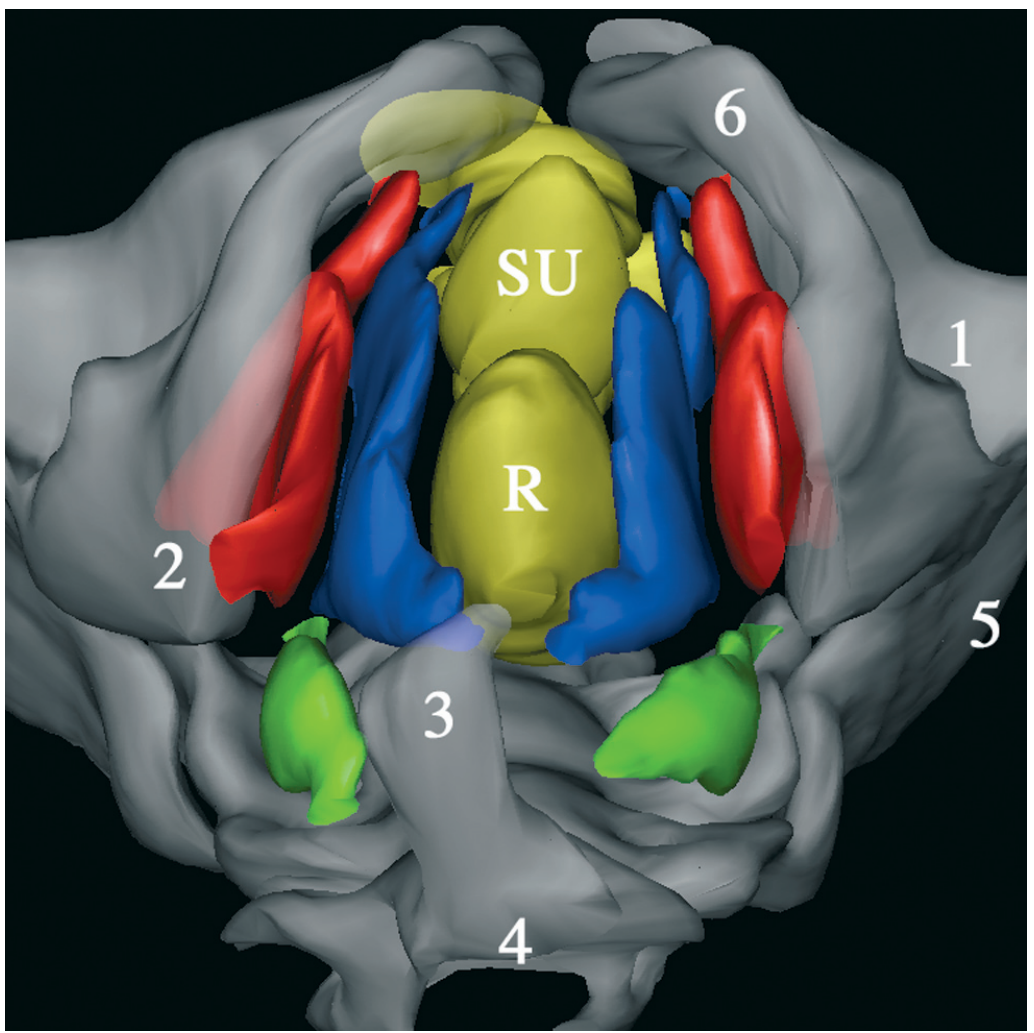

Figure $43 \mathrm{~mm} .9$

View on the pelvic diaphragm from below.

$\mathbf{R}$, rectum; $\mathbf{S U}$, sinus urogenitalis; $\mathbf{1}$, acetabulum; $\mathbf{2}$, ramus ossis ischii / tuber ischiadicum; $\mathbf{3}$, os coccygis; $\mathbf{4}$, last sacral vertebra; $\mathbf{5}$, os ilium; 6, ramus inferior ossis pubis; red, m. obturatorius internus; blue, m. levator ani; green, $\mathrm{m}$. coccygeus.

Note the 'four quadrant' formation of the pelvic diaphragm. The $\mathrm{m}$. coccygeus is less developed than in the $50 \mathrm{~mm}$ fetus. 


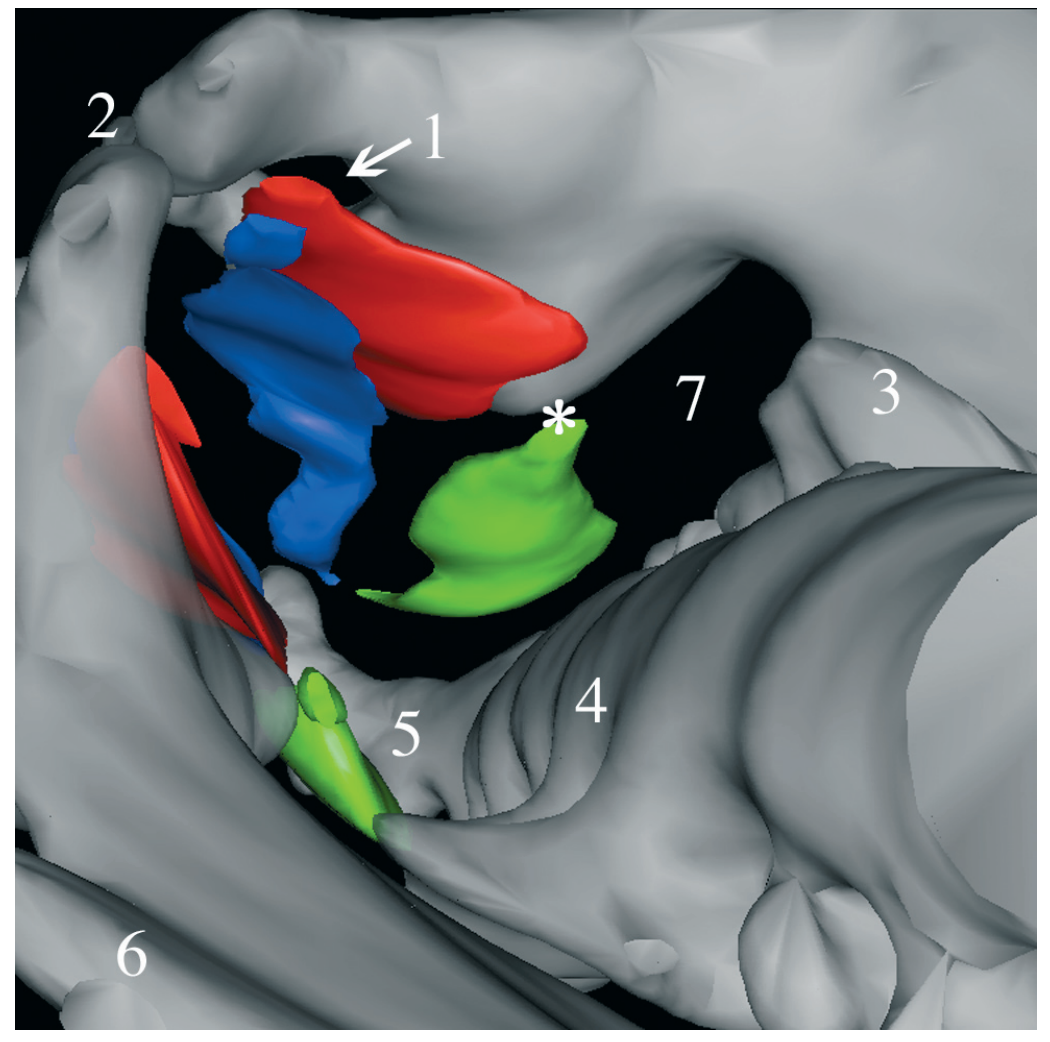

Figure 34mm.7

View from above, on the pelvic diaphragm.

$\mathbf{1}$, foramen obturatum; $\mathbf{2}$, symphysis pubica;

$\mathbf{3}$, pars lateralis os sacrum; $\mathbf{4}$, os sacrum; $\mathbf{5}$, os coccygis; $\mathbf{6}$, ala ossis ilii; $\mathbf{7}$, foramen ischiadicum majus; *, future spina ischiadica; red, m. obturatorius internus; blue, $\mathrm{m}$. levator ani; green, $m$. coccygeus.

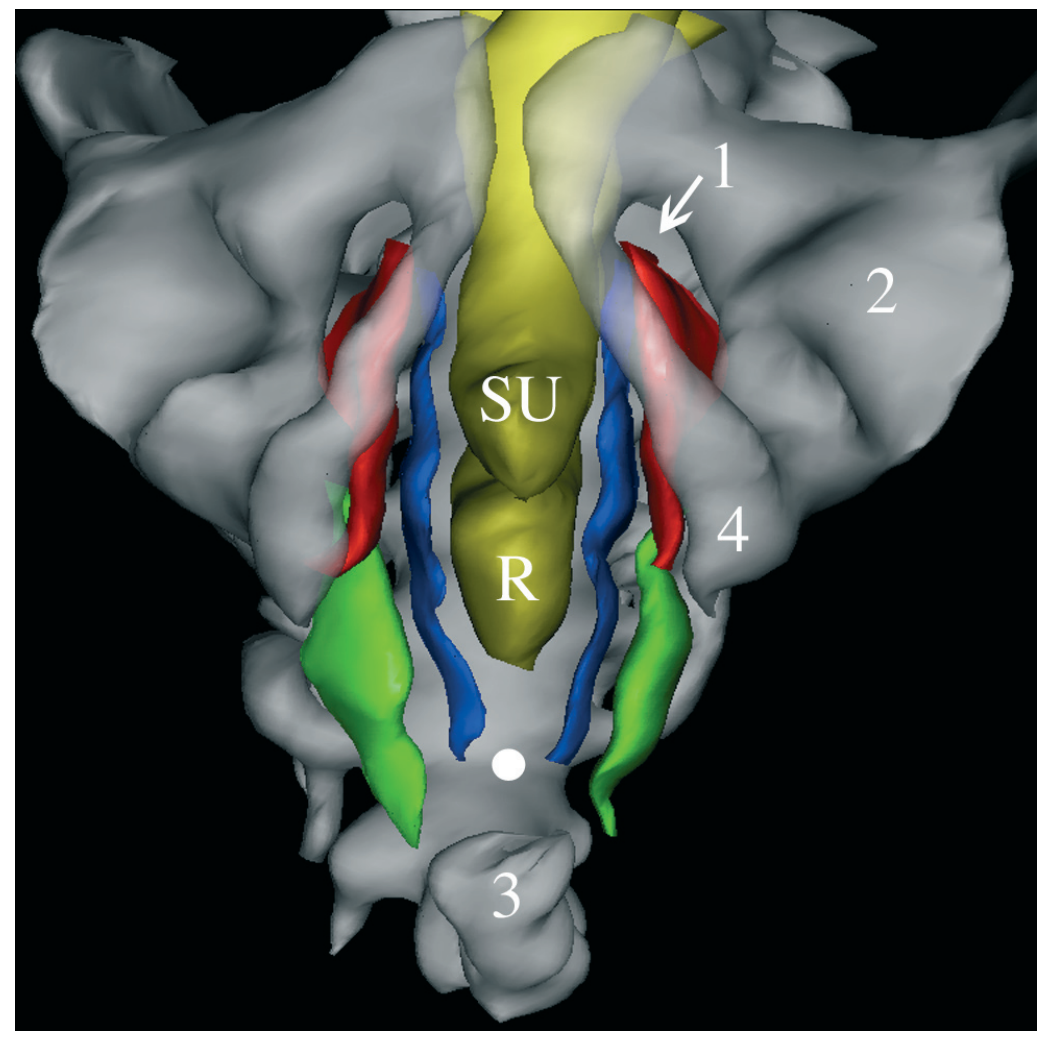

Figure $34 \mathrm{~mm} .8$

Frontal view of the pelvic diaphragm.

$\mathbf{R}$, rectum; $\mathbf{S U}$, sinus urogenitalis; $\mathbf{1}$, foramen obturatum; $\mathbf{2}$, acetabulum; $\mathbf{3}$, os coccygis; $\mathbf{4}$,

ramus ossis ischii; white dot, future ligamentum anococcygeum; red, $\mathrm{m}$. obturatorius internus; blue, m. levator ani; green, m. coccygeus. 


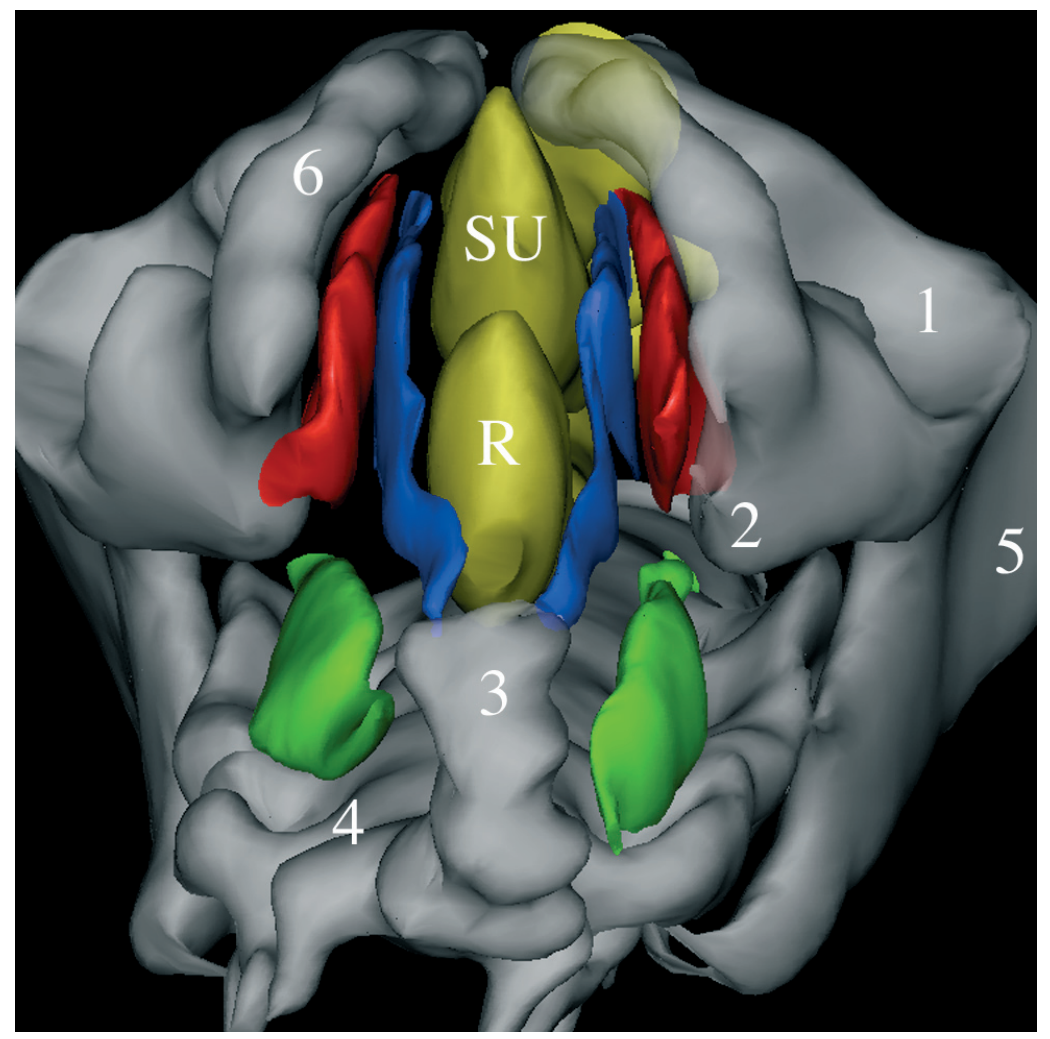

Figure 34mm.9

View of the pelvic diaphragm from below.

$\mathbf{R}$, rectum; $\mathbf{S U}$, sinus urogenitalis; $\mathbf{1}$, acetabu-

lum; 2, ramus ossis ischii at level of developing spina ischiadica; $\mathbf{3}$, os coccygis; $\mathbf{4}$, os sacrum; $\mathbf{5}$, os ilium (ala ossis ilii); $\mathbf{6}$, ramus inferior ossis pubis; red, $\mathrm{m}$. obturatorius internus; blue, $\mathrm{m}$. levator ani; green, m. coccygeus.

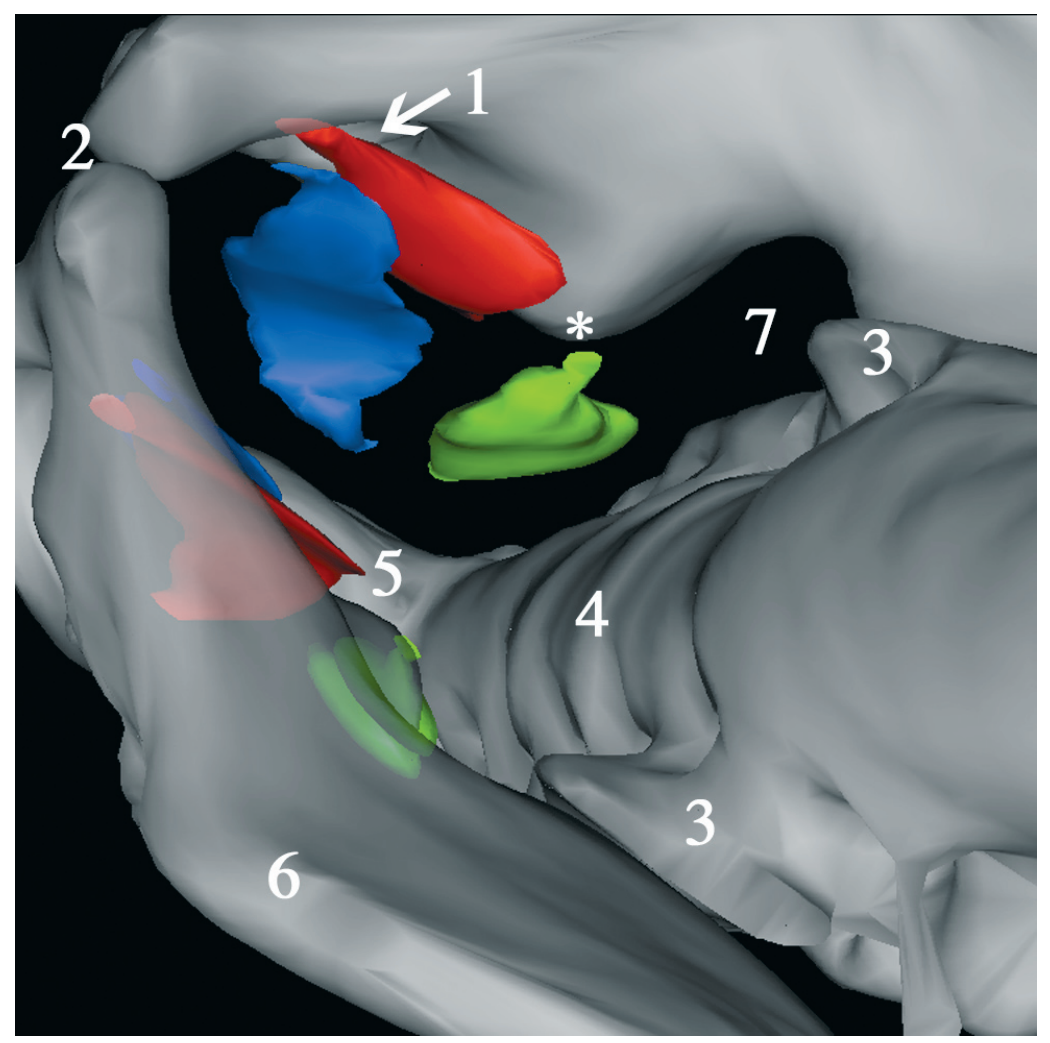

Figure 28mm.6

View from above on the pelvic diaphragm. $\mathbf{1}$, foramen obturatum; $\mathbf{2}$, symphysis pubica; $\mathbf{3}$, pars lateralis os sacrum; $\mathbf{4}$, os sacrum; $\mathbf{5}$, os coccygis; $\mathbf{6}$, ala ossis ilii; $\mathbf{7}$, foramen ischiadicum majus; *, future spina ischiadica; red, m. obturatorius internus; blue, m. levator ani; green, $m$. coccygeus. 


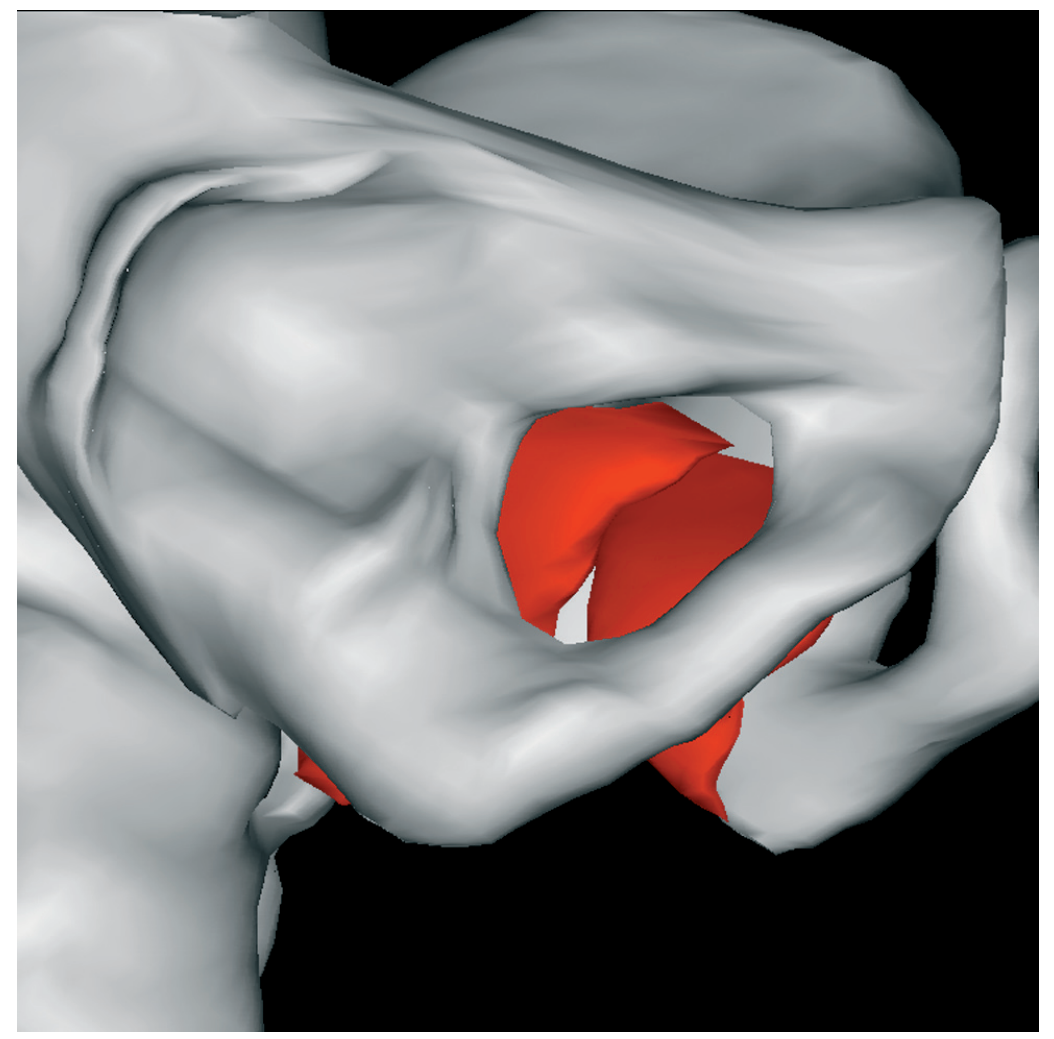

Figure 28mm.7

View of the right foramen obturatum.

The m. obturatorius internus is reconstructed

in red. Note that the muscle does not cover the frontal half and cranial quarter of the foramen obturatum.

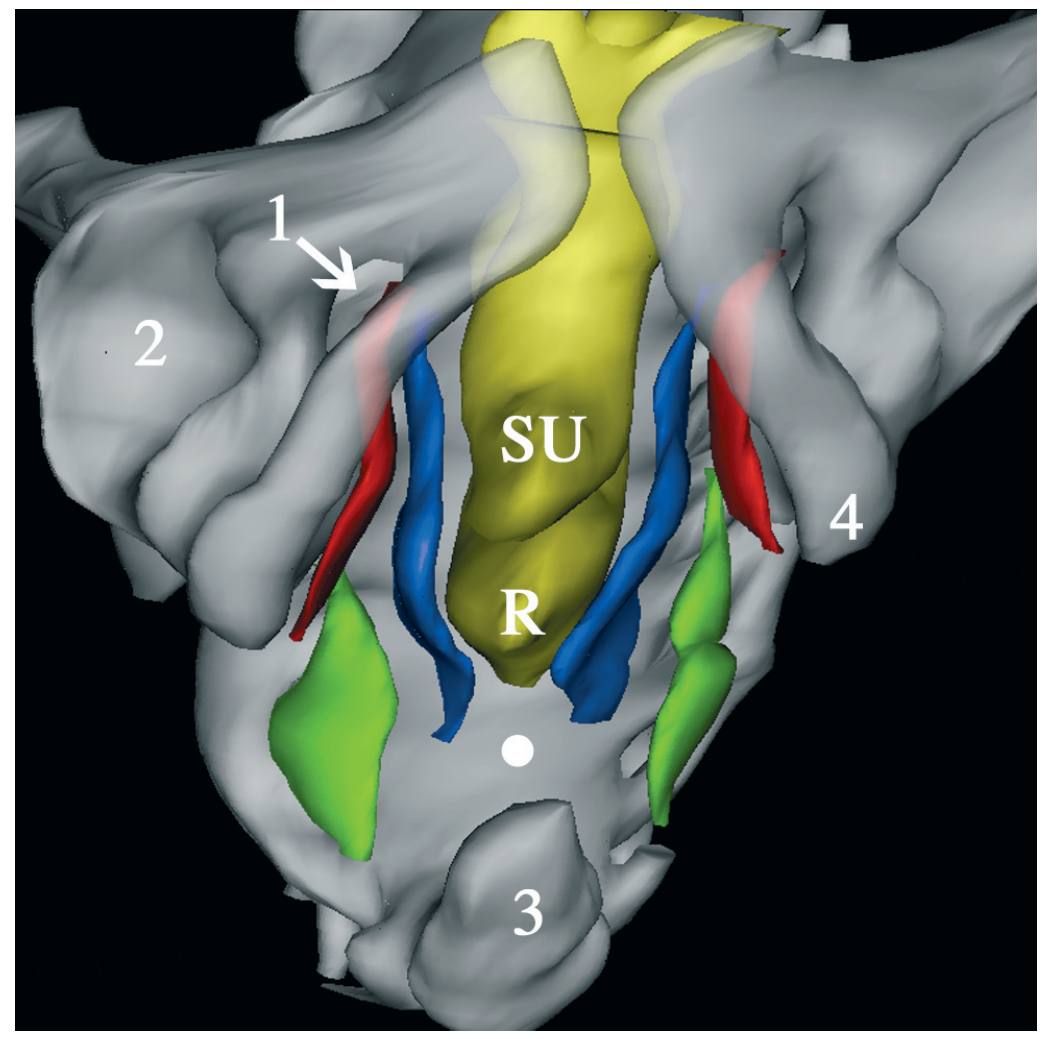

Figure $28 \mathrm{~mm} .8$

Frontal view of the pelvic diaphragm.

$\mathbf{R}$, rectum; $\mathbf{S U}$, sinus urogenitalis; $\mathbf{1}$, foramen obturatum; $\mathbf{2}$, acetabulum; $\mathbf{3}$, os coccygis; $\mathbf{4}$, ramus ossis ischii; white dot, future ligamentum anococcygeum; red, $\mathrm{m}$. obturatorius internus; blue, $\mathrm{m}$. levator ani; green, $\mathrm{m}$. coccygeus. Note the absence of the curving between the sinus urogenitalis and the rectum (the future centrum tendineum). 


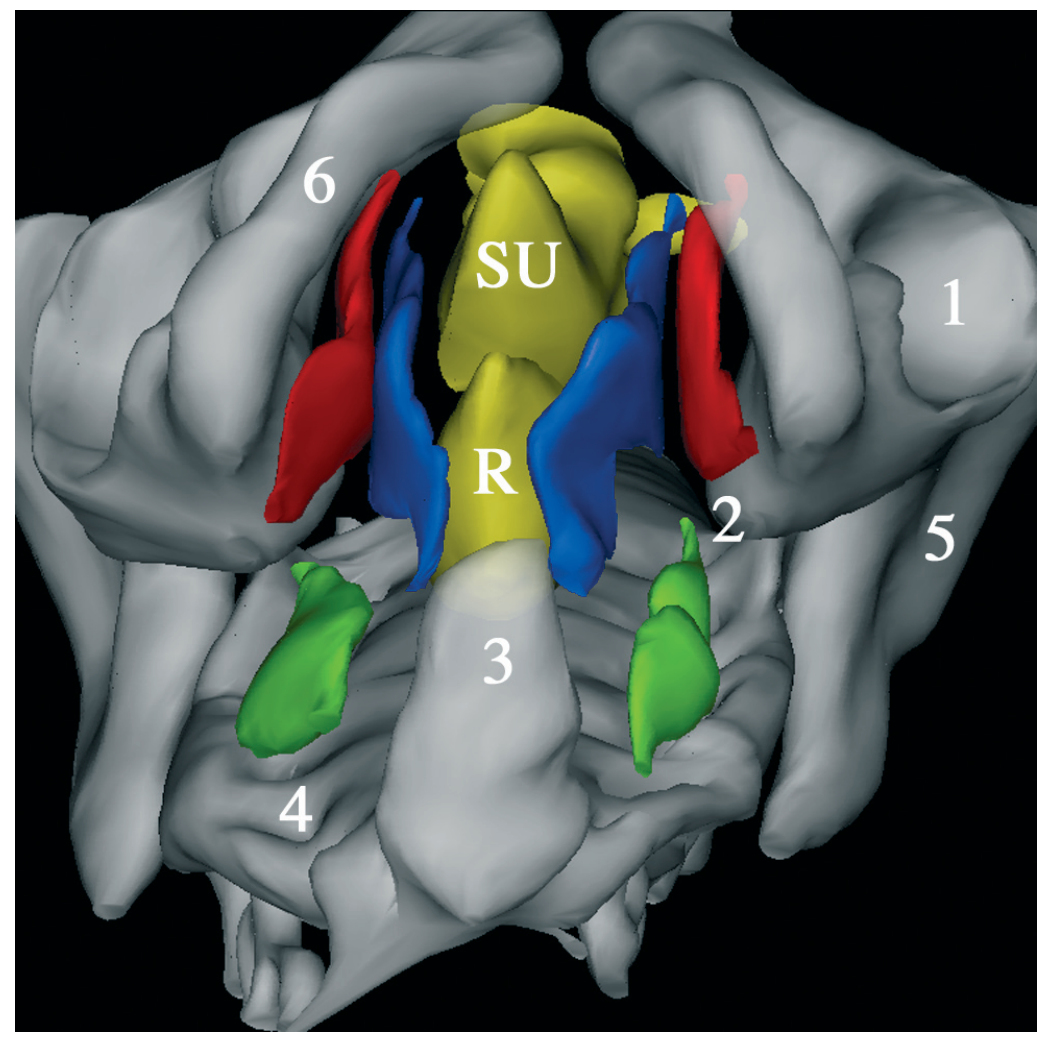

Figure 28mm.9

View of the pelvic diapragm from below.

$\mathbf{R}$, rectum; $\mathbf{S U}$, sinus urogenitalis; $\mathbf{1}$, acetabu-

lum; $\mathbf{2}$, ramus ossis ischii at level of developing spina ischiadica; $\mathbf{3}$, os coccygis; $\mathbf{4}$, os sacrum; $\mathbf{5}$, os ilium (ala ossis ilii); $\mathbf{6}$, ramus inferior ossis pubis; red, m. obturatorius internus; blue, $\mathrm{m}$. levator ani; green, m. coccygeus.

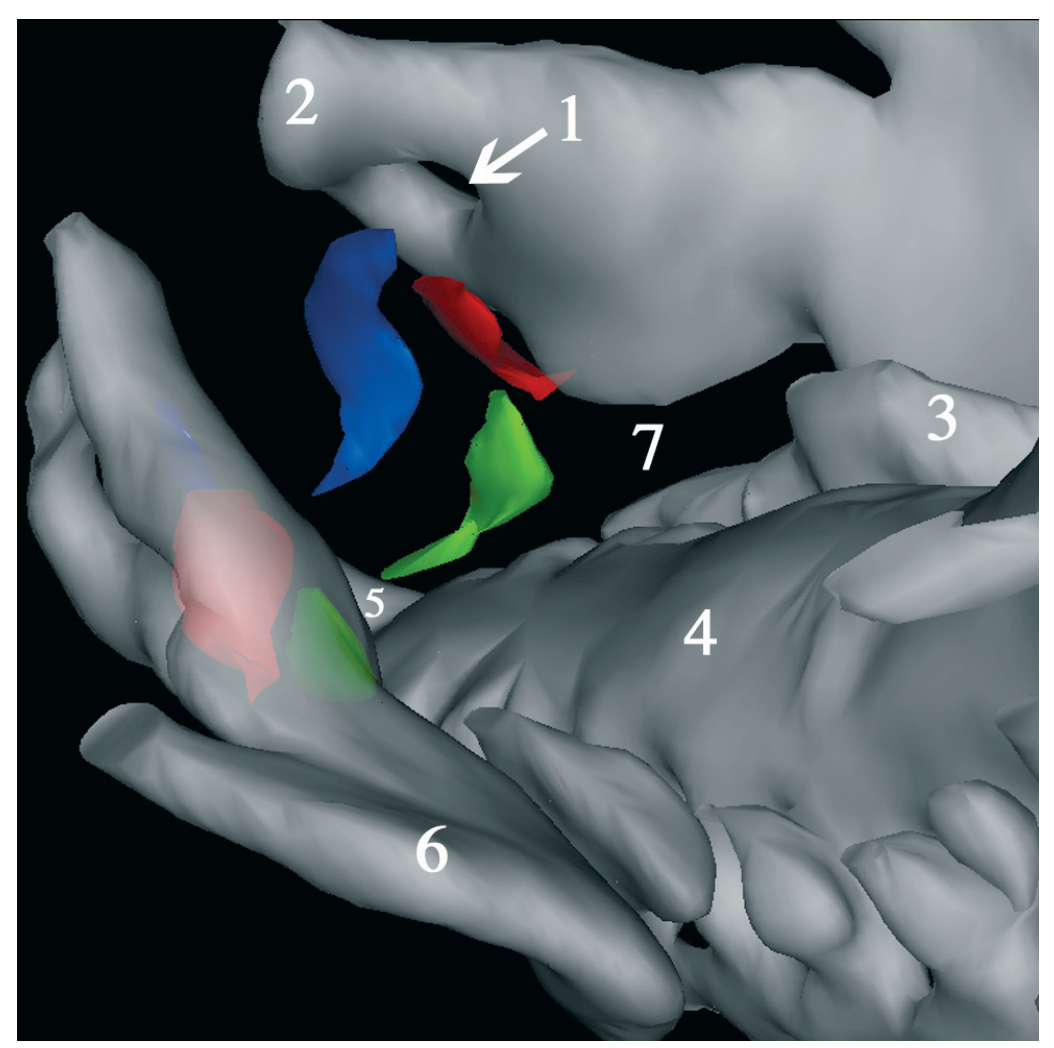

Figure $23 \mathrm{~mm} .6$

View from above on the pelvic diaphragm.

$\mathbf{1}$, foramen obturatum; $\mathbf{2}$, corpus ossis pubis;

$\mathbf{3}$, pars lateralis os sacrum; $\mathbf{4}$, os sacrum; $\mathbf{5}$, os coccygis; $\mathbf{6}$, ala ossis ilii; red, m. obturatorius internus; blue, m. levator ani; green, m. coccygeus. 


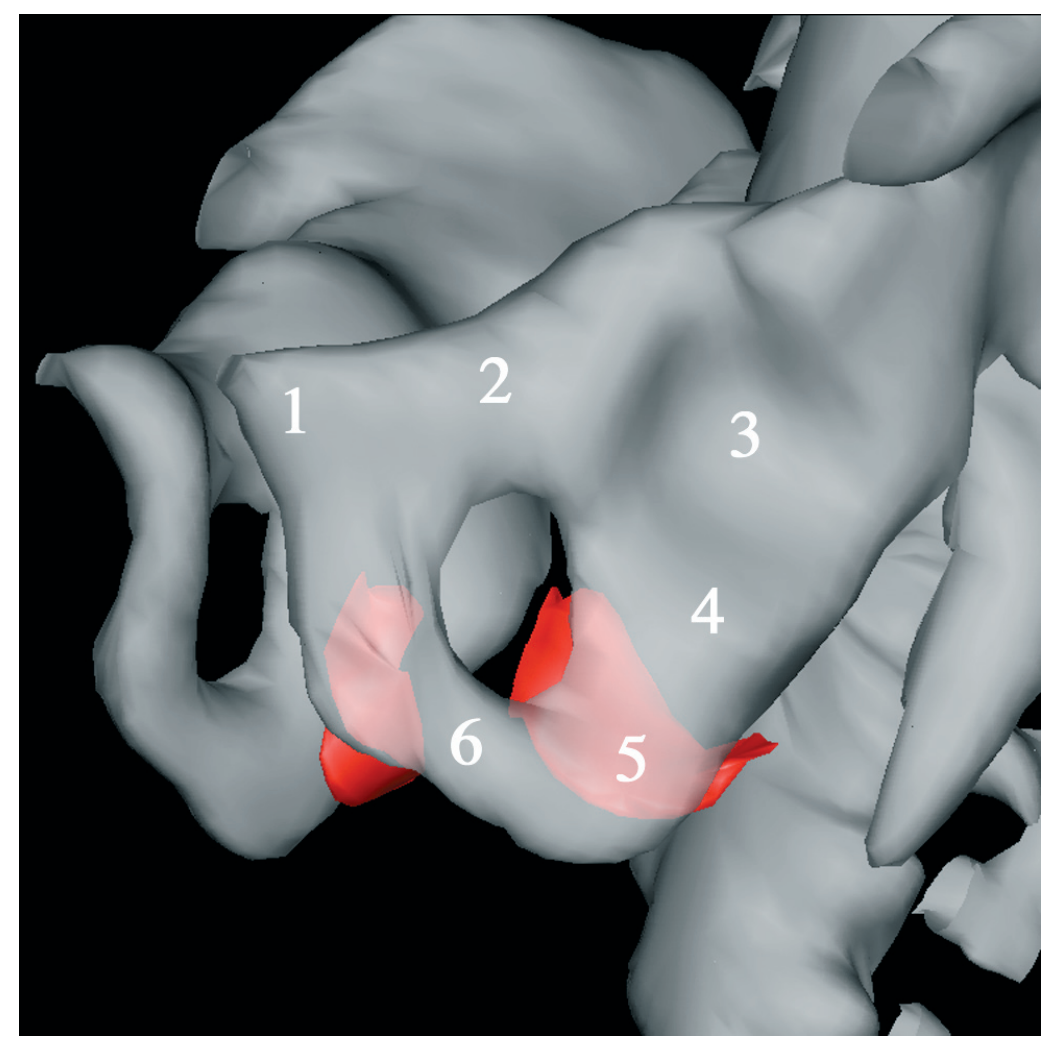

Figure $23 \mathrm{~mm} .7$

Close view of left foramen obturatum.

$\mathbf{1}$, corpus ossis pubis; $\mathbf{2}$, ramus superior ossis pubis; $\mathbf{3}$, acetabulum; $\mathbf{4}$, corpus ossis ischii; $\mathbf{5}$, ramus ossis ischii; $\mathbf{6}$, ramus inferior ossis pubis; red, $\mathrm{m}$. obturatorius internus.

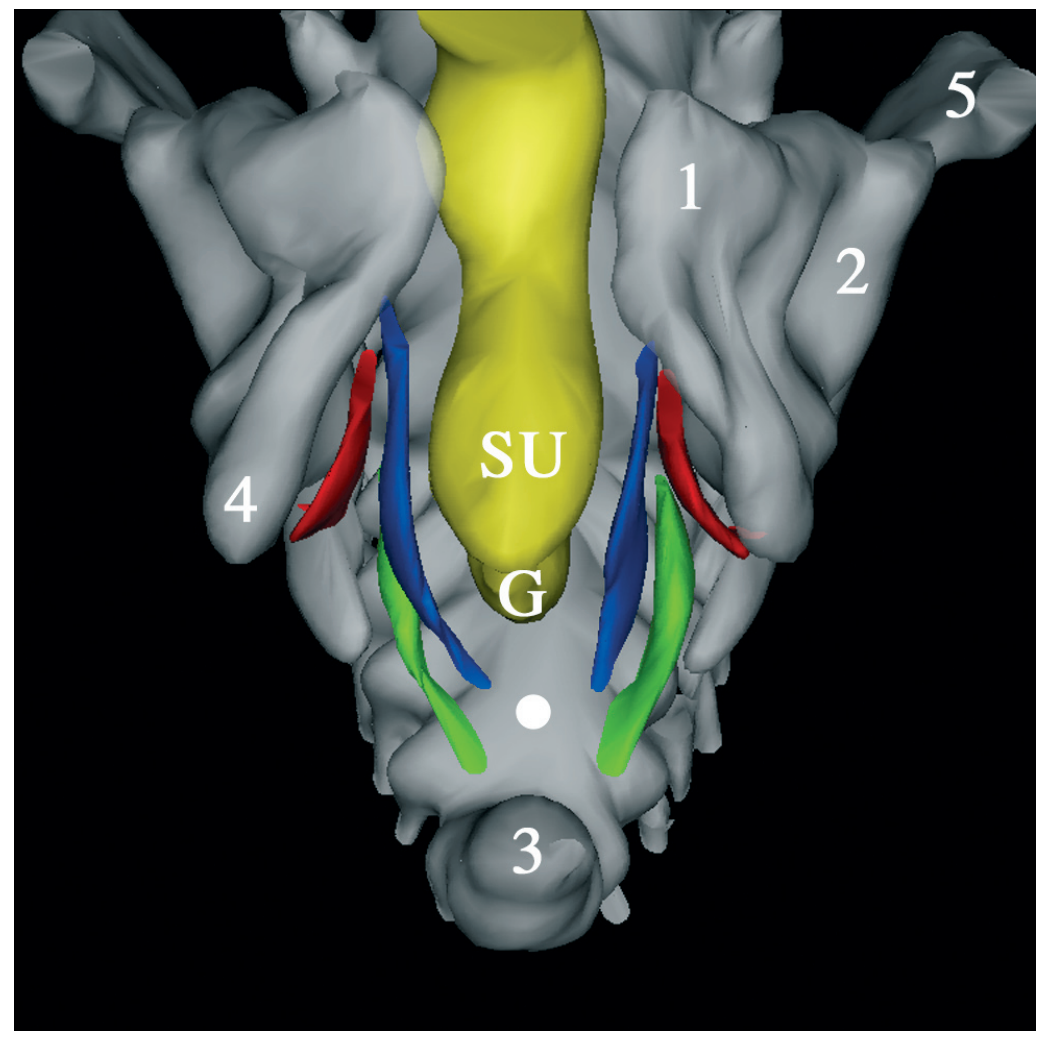

Figure 23mm.8

Frontal view of the pelvic diaphragm.

G, hindgut; $\mathbf{S U}$, sinus urogenitalis; $\mathbf{1}$, corpus ossis pubis; $\mathbf{2}$, acetabulum; $\mathbf{3}$, os coccygis; $\mathbf{4}$ ramus ossis ischii; $\mathbf{5}$, ala ossis ilii; white dot, future ligamentum anococcygeum; red, m. obturatorius internus; blue, m. levator ani; green, $\mathrm{m}$. coccygeus. 


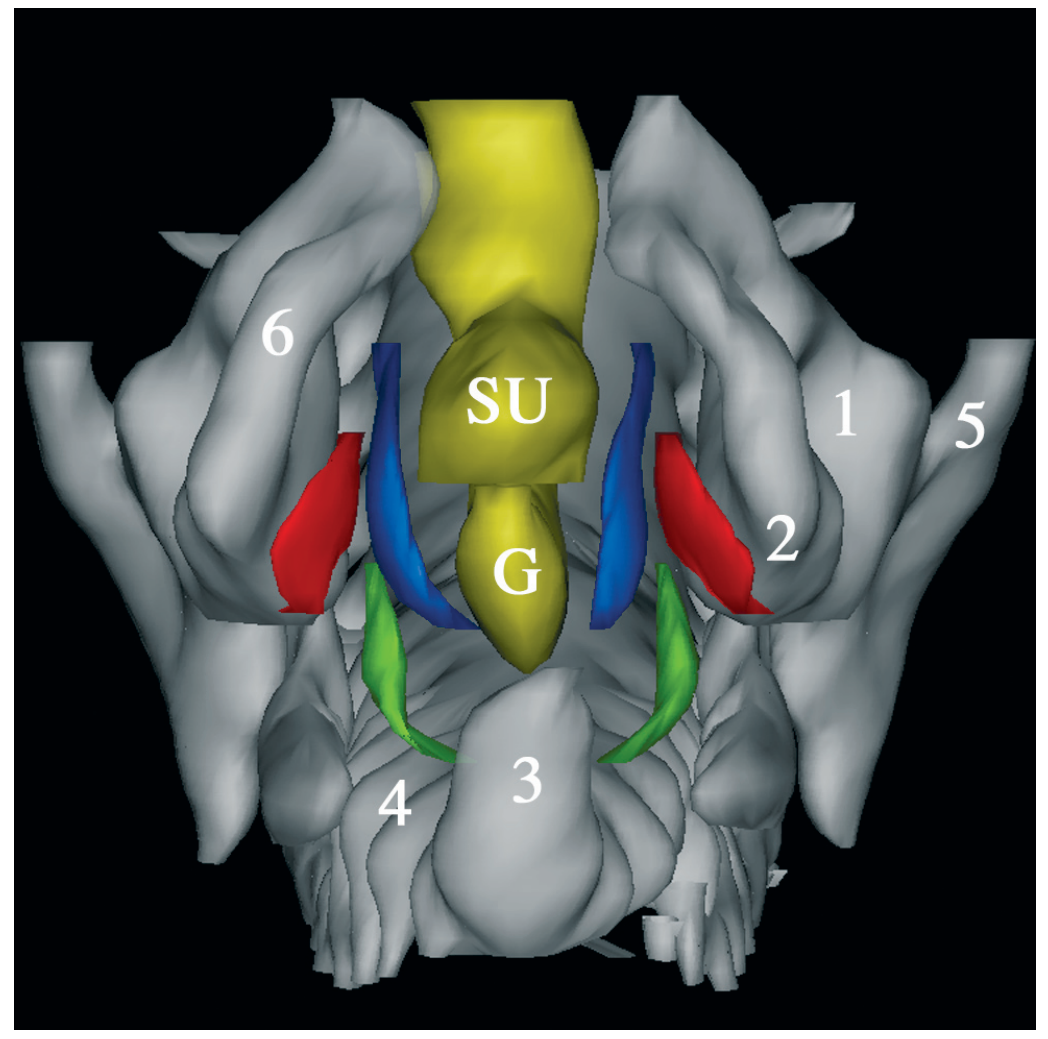

Figure $23 \mathrm{~mm} .9$

View of the pelvic diaphragm from below.

$\mathbf{G}$, hindgut; $\mathbf{S U}$, sinus urogenitalis; $\mathbf{1}$, acetabulum; 2 , ramus ossis ischii at level of developing spina ischiadica; $\mathbf{3}$, os coccygis; $\mathbf{4}$, os sacrum; $\mathbf{5}$, os ilium (ala ossis ilii); 6 , ramus inferior ossis pubis; red, m. obturatorius internus; blue, $\mathrm{m}$. levator ani; green, m. coccygeus. 


\section{Curriculum Vitae}

Wijnand Koch was born on April 28 $8^{\text {th }} 1969$ in Tilburg, The Netherlands.

After graduating high school (Atheneum at the Fioretticollege in Lisse), he started his medical training at the Free University of Amsterdam in 1987. During this period he worked as a student-assistant in the IVF-laboratory of the 'Diaconessenhuis Voorburg', under the guidance of Gynaecologist dr. C.A.M. Jansen (1990-1992). Here his interest in Gynaecology and Urology awakened.

Following the doctoral exam in 1991, he obtained his medical degree at the Leiden University in 1994.

From 1994 until 1995 he worked as a physician at the department of Urology at the Catholic University of Nijmegen (Prof.dr. F.M.J. Debruyne) under the guidance of Urologist dr. J.A. Witjes.

In September 1995 he started his residency training in Urology. Up until December 1997 he worked at the department of General Surgery at the 'Rijnland Ziekenhuis Leiderdorp' (dr. J.F.W.B. Rijksen), after which he worked as a resident at the Leiden University Medical Centre (1998 and 2001, Prof.drs. J. Zwartendijk) and the 'Ziekenhuis Leyenburg' in The Hague (1999 and 2000 , dr. P.L. Venema). In this period he started the research, which eventually resulted in this thesis, at the Leiden University under the guidance of his promotor Prof.dr. E. Marani.

He certified as an Urologist on January $1^{\text {st }} 2002$ and is working from that moment on as an Urologist at the 'Medisch Centrum Alkmaar' in Alkmaar, The Netherlands. He certified as a Fellow of the European Board of Urology (FEBU) on June $14^{\text {th }} 2003$.

$\mathrm{He}$ is married to Anne-Marie Nagtegaal and has two daughters: Maartje en Femke.

\section{Publications}

The outcome of renal ultrasound in the assessment of 556 consecutive patients with benign prostatic hyperplasia. Koch, W; Ezz El Din, K; de Wildt, M; Debruyne, F; de la Rosette, J. J Urol. 1996; 155(1): 186-9.

Reliability of the International Prostate Symptom Score in the assessment of patients with lower urinary tract symptoms and/or benign prostatic hyperplasia. Ezz El Din, K; Koch, W; de Wildt, M; Kiemeney, L; Debruyne, F; de la Rosette, J. J Urol. 1996; 155(6): 1959-64.

The predictive value of microscopic haematuria in patients with lower urinary tract symptoms and benign prostatic hyperplasia. Ezz El Din, K; Koch, W; de Wildt, M; Debruyne, F; de la Rosette, J. Eur Urol. 1996(30): 409-13.

Wat is het verschil in symptomatologie tussen benigne prostaathyperplasie en blaashalsstenose? Koch, W; Lycklama à Nijeholt, A. Vademecum, permanente nascholing voor huisartsen. 1999; 17(7).

Nieuw in de urologische keuken: de prostaatmagnetron. Koch, W. De Ley, medisch tijdschrift van Ziekenhuis Leyenburg. 2000; 7(1): 30-2.

Anatomy and neurophysiology of the pelvic floor. Marani, E; Koch, W; Kinder, M; Heldoor, M. In: The Pelvic Floor, Congenital Anomalies From Children to Adults.

Edizioni Goliardiche,Trieste. 2005:15-23. 


\section{Presentations}

Is there a higher chance of success in IVF recidivists?

Koch, W; van Os, H; Schats, R; Jansen, C.

8th Annual Meeting of the European Society of Human Reproduction and Embryology (ESHRE). Den Haag, 1992.

Echografie van de nieren bij screening van BPH: bestaat hiervoor een indicatie?

Koch, W; de Wildt, M; te Slaa, E; Debruyne, F; de la Rosette, J.

Voorjaarsvergadering Nederlandse Vereniging voor Urologie, 1995.

De betekenis van microscopische haematurie bij benigne prostaathyperplasie.

Koch, W; de Wildt, M; te Slaa, E; Debruyne, F; de la Rosette, J.

Voorjaarsvergadering Nederlandse Vereniging voor Urologie, 1995.

European Association of Urology (EAU) Highlight Meeting 2001.

Koch, W. Verslaglegging BPH (Benigne Prostaat Hyperplasie). EAU Geneve 2001. 
DANKWOORD

'ZIJ DIE BEDANKT WORDEN, WETEN DAT ZE BEDANKT WORDEN.' 



\title{
Stellingen \\ Behorend bij het proefschrift \\ Early Development of the Human Pelvic Diaphragm door
}

\author{
Wijnand F.R.M. Koch
}

1 De beschreven ontwikkeling van het diaphragma pelvis door Popowsky [1899], Power [1948] en Fritsch [1994] is onjuist. De anatomische onderverdeling van de musculus levatoris ani in meerdere spieren kan embryologisch niet worden ondersteund: het is één spier, die onderdeel is van de musculus sphincter ani externus en zich ontwikkelt van ventraal naar dorsaal. (dit proefschrift)

Popowsky J (1899). Zur entwickelungsgeschichte der Dammuskulatur beim Menschen Anat Hefte, Abt. 1, Bd 12, H. 38, 13-48. Power (1948). Embryological development of the levator ani muscle. Am J Obstet Gynaecol 55(3): 367-381.

Fritsch H, Fröhlich B (1994a). Development of the levator ani muscle in human fetuses. Early Hum Dev.; 37 : $15-25$.

2 De embryologische ontwikkeling van het diaphragma pelvis is onafhankelijk van de ontwikkeling van het diaphragma urogenitale en, in tegenstelling tot het diaphragma urogenitale, niet geslachtsafhankelijk. (dit proefschrift)

3 Het foramen obturatum is, uit oogpunt van de ontwikkeling, niet de origo maar de insertie van de musculus obturatorius internus. Het foramen wordt gevuld door de membrana obturatoria, wiens ontwikkeling geïnduceerd wordt door de zich ontwikkelende musculus obturatorius internus. (dit proefschrift)

$4 \quad$ Het diaphragma pelvis ontwikkelt zich dubbelzijdig en vanuit drie richtingen. De mediale sluiting ontstaat door externe factoren: de ontwikkeling van het centrum tendineum, het ligamentum anococcygeum en het os pubis. De positie van het diaphragma wordt bepaald door de stand van de wervelkolom. (dit proefschrift)

5 De musculus puborectalis, of puborectale sling, bestaat niet. (dit proefschrift)

6 De musculus coccygeus is onderdeel van het diaphragma pelvis en het ligamentum sacrospinale is het verbindweefselde deel van deze spier, hetgeen de volwassen anatomische situatie verklaart. (dit proefschrift)

7 De reconstructie van de bekkenbodem bij extrophia vesicae is van cruciaal belang voor het bereiken van continentie.

de Jong, TP (2001). Surgical aspects of pediatric urinary incontinence. Chapter 6: Bladder extrophy and epispadias. Thesis, Utrecht

8 Het bestaan van een 'mediastinum pelvis' is alleen waar, wanneer het anale sphinctercomplex als een onderdeel van het diaphragma pelvis wordt gezien. Marani, E (2002). The Pelvis: Another View. Twente University Press, Enschede

9 De Functionele Urologie is een aandachtsgebied dat zich bij uitstek leent tot het aangaan van nauwe relaties met Biomedische Technologie en Technische Geneeskunde.

10 Marktwerking in de gezondheidszorg is een contradictio in terminis.

Enschede, 30 juni 2006 